\title{
PERMANÊNCIA E INOVAÇÃO: \\ O ANTIGO E O NOVO NOS PROJETOS URBANOS DE LINA BO BARDI
}

Raíssa Pereira Cintra de Oliveira

Dissertação apresentada ao Programa de Pós-Graduação da Faculdade de Arquitetura e Urbanismo da Universidade de São Paulo, na área de Fundamentos e História da Arquitetura e Urbanismo, como parte dos requisitos para a obtenção do título de mestre.

orientação

Profa. Dra. Fernanda Fernandes da Silva 
AUTORIZO A REPRODUÇÃO E DIVULGAÇÃO TOTAL OU PARCIAL DESTE TRABALHO, POR QUALQUER MEIO CONVENCIONAL OU ELETRÔNICO, PARA FINS DE ESTUDO E PESQUISA, DESDE QUE CITADA A FONTE.

E-MAIL: raisamarela@yahoo.com.br

Oliveira, Raíssa Pereira Cintra de

048p Permanência e inovação: 0 antigo e novo nos projetos urbanos de Lina Bo Bardi / Raíssa Pereira Cintra de Oliveira. --São Paulo, 2008. 205 p. : il.

Dissertação (Mestrado - Área de Concentração: História e Fundamentos da Arquitetura e Urbanismo) - FAUUSP.

Orientadora: Fernanda Fernandes da Silva

1.Arquitetura moderna 2.Espaço público 3.Centros históricos restauração 4.Política cultural 5.Prática profissional 6.Bardi Lina Bo, 1914-1992 I.Título

CDU 72.036 
Esta pesquisa teve 0 apoio da FAPESP 
À FAPESP pela bolsa concedida sem a qual não teria a mesma dedicação e amadurecimento.

À minha orientadora Fernanda Fernandes da Silva pelos momentos de dedicação e por acreditar no meu trabalho.

Aos professores e amigos da PUC-Campinas que juntos compartilharam um grande momento da escola - momentos de paixão e dedicação.

Aos grupos de trabalho que tiveram grande importância na minha formação, e que hoje tanto me fazem falta: L'Habitat, USINA e CPC/USP.

À Claudia Reis, minha irmã de coração, pelos momentos de discussão, reflexão e ajuda mútua fundamental para o meu amadurecimento. Eron Souza pela alegria e companheirismo.

À Magaly Marques pela amizade, sinceridade, cumplicidade; pelas quartas-feiras nos tempos da faculdade, e principalmente pelo "mau-humor necessário". João Marcos Lopes por acreditar na nossa geração e compartilhar conosco sua sabedoria e carinho. Aos dois juntos que no início dessa empreitada tanto acreditaram em mim.

Não tenho palavras para descrever a gratidão que sinto em poder compartilhar momentos da minha vida com meus eternos amigos Teresa Borsoi, Joana D'Andrea, Andréa Arruda, Eduardo Correa e André Carvalho.

À Silvana Romano e Abílio Guerra que sempre deram grande apoio.

Àqueles que ajudaram na realização desta dissertação: ao Professor Renato Anelli, Marcelo Suzuki, Marcelo Ferraz, Maurício Chagas, ao Instituto P. M. e Lina Bo Bardi em especial Liana - aos funcionários do Solar do Unhão na Bahia, à Nicia e à Denise Teixeira.

À minha grande paixão, meu companheiro Alexandre, pelo incentivo e paciência neste período de introspecção. Agradeço estes que me receberam com tamanho carinho: Sydney, Célia, Marco Antonio, Henrique e Caio.

Por fim, nada seria possível sem o apoio da minha família. Aos meus pais que me deram a melhor de todas as infâncias. Paulinho, meu pai, que me deu o gosto pelas praças das cidades e sempre incentivou a minha formação acadêmica. Ângela, minha mãe, que sempre esteve presente como um anjo abrindo meus olhos para a leveza da vida. Aos meus irmãos Yuri e lgor pelas nossas diferenças e pelo nosso amor. 
Esta dissertação pretende investigar a atuação profissional da arquiteta Lina Bo Bardi, mais particularmente analisando e discutindo o modo como a arquiteta procura solucionar a relação entre 0 antigo e o novo nas intervenções em espaços públicos considerados representativos da memória coletiva. Primeiramente, investiga-se sua formação e trajetória a fim de apontar alguns momentos paradigmáticos da discussão sobre a possibilidade do convívio entre permanência e inovação, o que, de certa forma, condiz com uma postura crítica frente à idéia de ruptura com o passado promovida pelo movimento moderno de vanguarda. Desta forma, são estudadas as nuances históricas da convivência entre 0 antigo e o novo, principalmente a partir das reflexões inseridas no contexto do pós-guerra europeu, onde a destruição de inúmeras cidades projeta grandes expectativas com relação à reconstrução, e conseqüentemente, suscita, nos domínios das disciplinas da arquitetura, do urbanismo e do restauro, importantes discussões sobre o modo de se fazer tais intervenções. Num segundo momento, são analisados dois projetos de Lina - a proposta para o Concurso: Vale do Anhangabaú em São Paulo e o Projeto para o Centro Histórico de Salvador, ambos da década de 1980, entendidos aqui como exemplos significativos de intervenções urbanas na trajetória profissional da arquiteta e também reveladores de sua formação, ao mesmo tempo afinada com o debate do pós-guerra e em sintonia com a situação brasileira através de um olhar específico e crítico. Cabe dizer que estes projetos analisados são concebidos num momento em que as nossas categorias culturais estão sendo questionadas e modificadas num propósito de democratização e ampliação do acesso à cidade e, portanto, dos espaços públicos e da memória. Isto é verificado na tentativa de modernização do Sphan, órgão ligado à preservação dos bens patrimoniais, assim como na proliferação de concursos públicos. Esta abordagem reconstitui uma postura profissional baseada em práticas e fundamentos que podem contribuir para as atuações profissionais contemporâneas a fim de se colocar como contraponto dos discursos que participam de uma noção meramente especulativa das intervenções nas cidades.

Palavras-chave: Lina Bo Bardi; intervenções urbanas; centros históricos; restauração; política cultural; prática profissional. 
This is a research involving the architect Lina Bo Bardi's professional works, discussing and analyzing how she solves the relationship between old and new in the urban' interventions at public spaces of putative collective memory. Firstly It carry out a research about the origins and evolution of some paradigmatic moments in discussion about the possibilities of meeting between the establishment and innovation. Furthermore, It correlates to the critical' views of the idea of rupture with the past promoted by vanguard modern movement. It studies the pondering between old and new that have came out after second war period in the Europe, where the vast destruction of the cities gave the background for their reconstruction and It started important discussions about how to evolve these interventions in the context of architecture, urbanism, and restore projects issues. In the second moment, It analyzes two urban interventions projects of Lina: The propose for Vale do Anhangabau's Contest at São Paulo city and the other one for the Salvador's History Center, that have been done in the 1980. This period is featured by the political open in Brazil that able the discussion about the public space and the collective memory.

Key-words: Lina Bo Bardi; urban interventions; history center; restore and conservation project; cultural politic; professional practice. 


\section{- lista de siglas}

$\begin{array}{ll}\text { BNH } & \text { Banco Nacional de Habitação } \\ \text { CETA } & \text { Centro de Estudos e Trabalho Artesanal } \\ \text { CIAM } & \text { Congresso Internacional de Arquitetura Moderna } \\ \text { CNPU } & \text { Comissão Nacional de Política Urbana } \\ \text { CNRC } & \text { Centro Nacional de Referência Cultural } \\ \text { Emurb } & \text { Empresa Municipal de Urbanização } \\ \text { EPUC } & \text { Escritório do Plano Urbanístico da Cidade } \\ \text { Faec } & \text { Fábrica de Equipamentos Comunitários da Prefeitura Municipal de } \\ & \text { Salvador } \\ \text { FNpM } & \text { Fundação Nacional Pró-Memória } \\ \text { IAC } & \text { Instituto de Arte Contemporânea } \\ \text { IPAC } & \text { Instituto do Patrimônio Artístico e Cultural } \\ \text { Iphan } & \text { Instituto do Patrimônio Histórico e Artístico Nacional } \\ \text { MAMB } & \text { Museu de Arte Moderna da Bahia } \\ \text { MAP } & \text { Museu de Arte Popular } \\ \text { MAS } & \text { Movimento Studi per Architettura } \\ \text { MASP } & \text { Museu de Arte de São Paulo } \\ \text { MIAR } & \text { Movimento Italiano para a Arquitetura Racional } \\ \text { MEC } & \text { Ministério da Educação e Cultura } \\ \text { MSA } & \text { Movimento Studi Arquitettura } \\ \text { PCB } & \text { Partido Comunista Brasileiro } \\ \text { PCH } & \text { Programa Integrado de Reconstrução das Cidades Históricas } \\ \text { PRRNH } & \text { Programa de Recuperação e Revitalização de Núcleos Históricos } \\ \text { SEPLAN } & \text { Secretaria do Planejamento } \\ \text { Sphan } & \text { Serviço do Patrimônio Histórico e Artístico Nacional } \\ \text { Sudene } & \text { Superintendência para Desenvolvimento do Nordeste } \\ \text { UNE } & \text { União Nacional dos Estudantes } \\ \text { UNESCO } & \text { United Nations Educational, Scientific and Cultural Organization } \\ & \text { (Organização das Nações Unidas para Educação, Ciência e Cultura) } \\ & \\ & \end{array}$




$\begin{array}{lll}\text { capa } & & \text { FERRAZ, Marcelo - } \\ & & \text { arquivo pessoal } \\ \text { p.31 } & \text { Fig.1 } & \text { CARBONARA, 1997 } \\ \text { p.32 } & \text { Fig.2 } & \text { CARBONARA, 1997 } \\ \text { p.33 } & \text { Fig.3 } & \text { CHOAY, 2001 } \\ \text { p.34 } & \text { Fig.4 } & \text { CORBUSIER, 2004 } \\ \text { p.43 } & \text { Fig.5 } & \text { MOLINARI, 2000 } \\ \text { p.43 } & \text { Fig.6 } & \text { MOLINARI, 2000 } \\ \text { p.44 } & \text { Fig.7 } & \text { SOLÀ-MORALES, } \\ & & \text { 2003 } \\ \text { p.46 } & \text { Fig.8 } & \text { FERRAZ, 1993 } \\ \text { p.47 } & \text { Fig.9 } & \text { FERRAZ, 1993 } \\ \text { p.48 } & \text { Fig.10 } & \text { BARDI, 1950 } \\ \text { p.48 } & \text { Fig.11 } & \text { BARDI, 1950 } \\ \text { p.49 } & \text { Fig.12 } & \text { FERRAZ, 1993 } \\ \text { p.53 } & \text { Fig.13 } & \text { FERRAZ, 1993 } \\ \text { p.53 } & \text { Fig.14 } & \text { BARDI, 1994 } \\ \text { p.59 } & \text { Fig.15 } & \text { FERRAZ, 1993 } \\ \text { p.59 } & \text { Fig.15 } & \text { OLIVEIRA, 2006 } \\ \text { p.69 } & \text { Fig.17 } & \text { FERRAZ, 1993 } \\ \text { p.74 } & \text { Fig.18 } & \text { FERRAZ, 1993 } \\ \text { p.79 } & \text { Fig.19 } & \text { MOTTA, 1987 } \\ \text { p.81 } & \text { Fig.20 } & \text { MOTTA, 1987 } \\ \text { p.81 } & \text { Fig.21 } & \text { MOTTA, 1987 } \\ \text { p.81 } & \text { Fig.22 } & \text { MOTTA, 1987 } \\ \text { p.82 } & \text { Fig.23 } & \text { SANT'ANNA, 2004 } \\ \text { p.94 } & \text { Fig.24 } & \text { FONSECA, 2005 } \\ \text { p.111 } & \text { Fig.25 } & \text { IPAC, 1885 } \\ \text { p.115 } & \text { Fig.26 } & \text { FERRAZ, 1993 } \\ \text { p.126 } & \text { Fig.27 } & \text { LATORRACA, 2000 } \\ \text { p.126 } & \text { Fig.28 } & \text { FERRAZ, 2000 } \\ \text { p.138 } & \text { Fig.29 } & \text { FERRAZ, 2000 } \\ \text { p.141 } & \text { Fig.30 } & \text { FERRAZ, 2000 } \\ \text { p.141 } & \text { Fig.31 } & \text { foto da autora } \\ \text { p.141 } & \text { Fig.32 } & \text { foto da autora } \\ \text { p.142 } & \text { Fig.33 } & \text { FERRAZ, 2000 } \\ \text { p.142 } & \text { Fig.34 } & \text { foto da autora } \\ \text { p.144 } & \text { Fig.35 } & \text { FERRAZ, 2000 } \\ \text { p.144 } & \text { Fig.36 } & \text { FERRAZ, 2000 } \\ & & \end{array}$

$\begin{array}{lll}\text { p.144 } & \text { Fig.37 } & \text { FERRAZ, 2000 } \\ \text { p.145 } & \text { Fig.38 } & \text { FERRAZ, 2000 } \\ \text { p.146 } & \text { Fig.39 } & \text { FERRAZ, 2000 } \\ \text { p.146 } & \text { Fig.40 } & \text { FERRAZ, 2000 } \\ \text { p.147 } & \text { Fig.41 } & \text { FERRAZ, 2000 } \\ \text { p.147 } & \text { Fig.42 } & \text { FERRAZ, 2000 } \\ \text { p.147 } & \text { Fig.43 } & \text { FERRAZ, 2000 } \\ \text { p.148 } & \text { Fig.44 } & \text { LATORRACA, 2000 } \\ \text { p.149 } & \text { Fig.45 } & \text { FERRAZ, 2000 } \\ \text { p.150 } & \text { Fig.46 } & \text { FERRAZ, 2000 } \\ \text { p.152 } & \text { Fig.47 } & \text { FERRAZ, 2000 } \\ \text { p.153 } & \text { Fig.48 } & \text { FERRAZ, 2000 } \\ \text { p.153 } & \text { Fig.49 } & \text { FERRAZ, 2000 } \\ \text { p.156 } & \text { Fig.50 } & \text { FERRAZ, 2000 } \\ \text { p.157 } & \text { Fig.51 } & \text { arquivo Inst. Lina Bo } \\ & & \text { e P. M. Bardi } \\ \text { p.157 } & \text { Fig.52 } & \text { FERRAZ, 2000 } \\ \text { p.168 } & \text { Fig.53 } & \text { arquivo Inst. Lina Bo } \\ & & \text { e P. M. Bardi } \\ \text { p.170 } & \text { Fig.54 } & \text { EMURB, 1981 } \\ \text { p.178 } & \text { Fig.55 } & \text { Revista Projeto (31), } \\ & & \text { 1981 } \\ \text { p.181 } & \text { Fig.56 } & \text { FERRAZ, Marcelo } \\ & & \text { arquivo pessoal } \\ \text { p.182 } & \text { Fig.57 } & \text { arquivo Inst. Lina Bo } \\ & & \text { e P. M. Bardi } \\ \text { p.182 } & \text { Fig.58 } & \text { arquivo Inst. Lina Bo } \\ & & \text { e P. M. Bardi } \\ \text { p.183 } & \text { Fig.59 } & \text { FERRAZ, 2000 } \\ \text { p.183 } & \text { Fig.60 } & \text { CORBUSIER, 2004 } \\ \text { p.186 } & \text { Fig.61 } & \text { FERRAZ, Marcelo - } \\ & & \text { arquivo pessoal } \\ \text { p.187 } & \text { Fig.61 } & \text { FERRAZ, Marcelo - } \\ & & \text { arquivo pessoal } \\ \text { p.187 } & \text { Fig.61 } & \text { SIMÕES, 2004 } \\ \text { p.189 } & \text { Fig.62 } & \text { FERRAZ, Marcelo - } \\ & & \text { arquivo pessoal } \\ & & \end{array}$




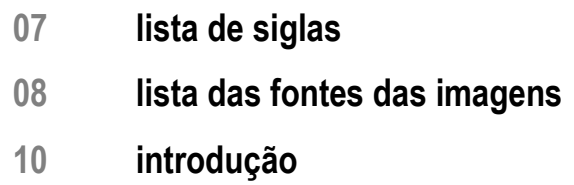

\section{PARTE 1}

o antigo e o novo em lina bo bardi

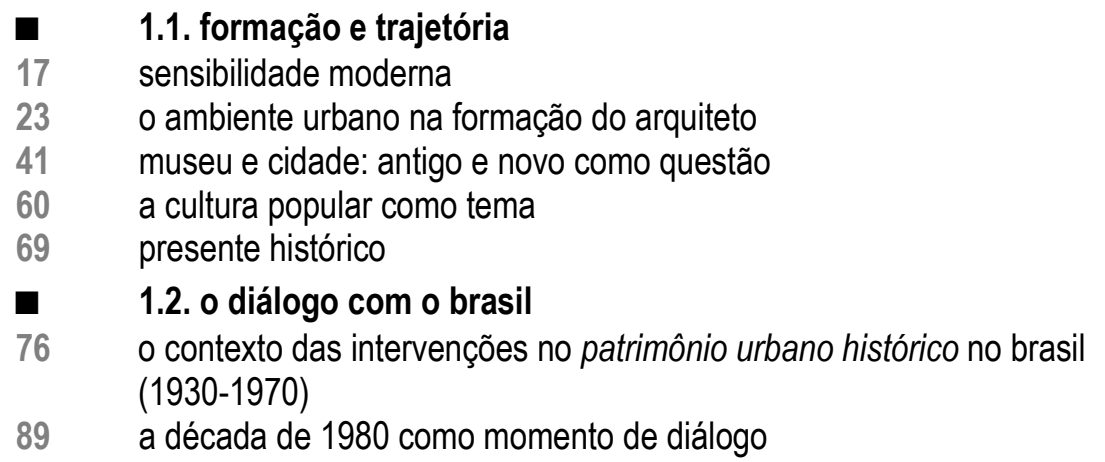

\section{PARTE 2}

intervenções urbanas de lina bo bardi: a cidade em sua complexidade

$\begin{array}{ll}\mathbf{1} & \text { 2.1. centro histórico de salvador } \\ 104 & \text { situação e o reconhecimento do patrimônio } \\ 113 & \text { momento político e a aproximação de salvador e lina } \\ 127 & \text { a concepção do projeto } \\ 140 & \text { casa do benin na bahia } \\ 145 & \text { projeto piloto ladeira da misericórdia } \\ 150 & \text { barroquinha } \\ 151 & \text { olodum } \\ 155 & \text { processo metodológico } \\ \mathbf{1} & \text { 2.2. concurso público: vale do anhangabaú } \\ 164 & \text { antecedentes } \\ 169 & \text { democracia e cidade: a proposta do concurso } \\ 172 & \text { o coração da cidade } \\ 179 & \text { metodologia e processo: lina e o vale do anhangabaú }\end{array}$

\footnotetext{
193 considerações finais

200 bibliografia
} 
sonho o poema de arquitetura ideal cuja própria nata de cimento encaixa palavra por palavra, tornei-me perito em extrair faíscas das britas e leite das pedras. acordo! e o poema todo se esfarrapa, fiapo por fiapo. acordo! o prédio, pedra e cal, esvoaça como um leve papel solto à mercê do vento e evola-se, cinza de um corpo esvaído de qualquer sentido acordo, e o poema-miragem se desfaz desconstruído como se nunca houvera sido.

A FÁBRICA DO POEMA

Adriana Calcanhoto Waly Salomão 


\section{- introdução}

Diante da grande quantidade de pesquisas sobre a arquiteta Lina Bo Bardi, parece tarefa fácil lidar com o estudo de suas obras. No entanto, revisitar questões suscitadas pela bibliografia e deparar-se com dois projetos particulares de intervenção urbana da arquiteta causou uma enorme inquietação perante 0 tema da relação entre o antigo e o novo estabelecido no projeto arquitetônico. Os dois projetos, o Centro Histórico de Salvador e a proposta para o Concurso: Vale do Anhangabaú, ambos concebidos na década de 1980, num primeiro instante chamam a atenção pela forma como a arquiteta lida com a preexistência, visivelmente distante do que se conhecia até então sobre a maneira de trabalhar com as intervenções em sítios históricos e de valor patrimonial. De qualquer forma, este tema parecia algo alheio ao que já se havia estudado sobre a arquiteta e, portanto, construir um novo olhar poderia ser uma tarefa bastante arriscada. No entanto, ao se debruçar sobre a bibliografia, descobriu-se que a proximidade feita entre 0 trabalho de Lina e as questões de cunho cultural e, em particular, sobre os métodos de restauração já era algo apontado em alguns artigos sobre a atuação da arquiteta, inclusive, com bastante empenho em estudos mais atuais na Universidade Federal da Bahia, lugar onde Lina atuou de modo considerável de 1958 a 1964. Percebeu-se, então, que esta enorme quantidade de trabalhos desenvolvidos poderia contribuir para aprofundar questões relativas ao tema.

A discussão sobre intervenções em espaços públicos considerados importantes marcos da cidade congrega ainda hoje muitas divergências. Nas últimas décadas, a proliferação de intervenções urbanas, principalmente nos chamados "centros históricos"1, vem acumulando experiências pautadas na rápida transformação da paisagem urbana seguida da substituição das dinâmicas culturais existentes por outras voltadas para o mercado de

\footnotetext{
10 conceito "centro histórico" nasce da extrema preocupação de proteção e, na verdade, delimita impropriamente o campo profissional, como se a partir daquele limite estabelecido não houvesse diálogo entre urbanistas, arquitetos e restauradores, o que acaba gerando apenas a função proibitiva dos profissionais da área da tutela sob a desmerecida cristalização daquele limite constituído de cidade. É necessário entender que esses centros também dependem de uma dinâmica territorial que o auto-sustente e que é primordial quebrar esse limite estipulado entre os técnicos durante o desenvolvimento do trabalho desta dimensão. Cf. ARGAN, Giulio Carlo. História da Arte como História da Cidade. São Paulo: Martins Fontes, 1998, p.79.
} 
entretenimento ou turístico. O Pelourinho em Salvador, o Dragão do Mar em Fortaleza e o Bairro do Recife ${ }^{2}$ são alguns exemplos desse tipo de prática no Brasil. ${ }^{3}$ Estas intervenções - preponderantemente ocorridas na década de 1990 no país - são, atualmente, evocadas de forma sistemática no campo acadêmico a fim de pormenorizar alguns fundamentos que as assistem. Dessa forma, evidencia-se freqüentemente uma vasta revisão destas intervenções denominadas de "embelezamento" ou gentrification ${ }^{4}$ - que, apesar das particularidades estabelecidas no âmbito dos referenciais empíricos em cada caso específico, consegue estabelecer um diálogo no interior deste debate. Percebe-se, então, um movimento de questionamento no âmbito acadêmico sobre o processo e os métodos usados durante a atuação do arquiteto, numa busca sistemática de se reverter as conseqüências da exclusão decorrente deste tipo de prática a partir da revisão das nossas categorias culturais e também de se compreender as reais dinâmicas do lugar. 0 entendimento destas categorias permite a construção das bases culturais próprias da nossa realidade e sua função é fundamentar o exercício tanto intelectual como prático.

Se pensarmos no período estabelecido como estudo, é exatamente na década de 1980 que nossas categorias culturais são questionadas e modificadas

\footnotetext{
2 Sobre o tema destaca-se a vasta quantidade de trabalhos sobre o a atuação no Pelourinho. Além de outros: PINHO, Osmundo S. de Araújo. Descentrando o Pelô: narrativas, territórios e desigualdades raciais no Centro Histórico de Salvador. Dissertação de Mestrado em Antropologia UNICAMP. Campinas, 1997; FERNANDES, Antônio Sergio. Empresarialismo urbano em Salvador: a recuperação do Centro Histórico do Pelourinho. Dissertação de Mestrado em Desenvolvimento Urbano. UFPE. Pernambuco, 1998; GOMES, Marco A de Filgueiras (org.) Pelo Pelô. História, Cultura e Cidade. Salvador: EDUFBA, 1995. Sobre a atuação em Fortaleza, ver FONTANELE, Sabrina Studart. Intervenções na cidade existente: um estudo sobre o Centro Dragão do Mar e a Praia de Iracema. Dissertação de Mestrado. FAU-USP. São Paulo, 2004. No caso do Bairro de Recife destaca-se: LEITE, Rogério Proença. Contra usos da cidade: lugares e espaço público na experiência urbana contemporânea. Campinas: Editora Unicamp, 2004.

${ }^{3}$ Essas práticas são consideradas problemáticas sob diversos aspectos, destacando-se a inversão de valores desses lugares, além do "saneamento" aparente dos problemas sociais. Intensifica-se o problema uma vez que as práticas estabelecidas pelos grandes centros de produção de conhecimento institucionalizado são praticamente importadas como meros simulacros e inseridas em realidades totalmente distintas. É possivel identificar esta prática quase "automática" nos Planos Diretores encomendados às pressas (sobre o cumprimento da vigência de leis) por cidades de pequeno e médio porte a escritórios dos grandes centros, os quais revelam verdadeiras "fórmulas" para intervenções ligadas ao desenvolvimento cultural da cidade e conseqüentemente para o destino do patrimônio histórico.

${ }^{4}$ Usando-se das palavras de Silvana Rubino: "Gentrification, termo cunhado na Inglaterra nos anos 1960, vem sendo utilizado nos estudos urbanos a partir da década de 1980 para dar conta do processo de aburguesamento ou enobrecimento pelo qual algumas áreas urbanas 'requalificadas' passam com a subseqüente substituição da população de baixa renda por outra mais "nobre", de práticas aburguesadas, inclusive culturas."Cf. RUBINO, Silvana Barbosa. Rotas da modernidade: trajetória, campo e história na atuação de Lina Bo Bardi, 1947-1968. Tese de Doutorado. IFCH, UNICAMP, 2002, p.16.
} 
num propósito de democratização e ampliação do acesso à cidade e, por conseguinte, dos espaços públicos e da memória. Isto fica evidente na tentativa de modernização do Sphan (serviço ligado à preservação dos nossos bens patrimoniais) já em andamento em 1970, quando se observa uma revisão de determinadas categorias culturais, sobretudo as que dizem respeito às noções de tempo (continuidade) e objeto (bem cultural) 5 . No entanto, a efetiva atuação do Sphan sobre os conjuntos de interesse memorial reflete a sua herança: uma política federal restrita ao instrumento do tombamento de grandes conjuntos, 0 que não deixa de significar uma escolha de símbolos abstratos e o espelho de uma nação única, idealizada e distante do que se preconiza sobre identidade ou representatividade de uma sociedade plural.

Concomitantemente, Lina trabalha em paralelo ao tom oficial - inclusive muitas vezes alheia ao instrumento do tombamento ${ }^{6}$, mas nem por isso seu procedimento sobre a cidade existente deixa de ser relevante. Apesar de sua posição marginal - no sentido de periférica ao tom oficial ou das classificações acadêmicas -, seu trabalho aparece sob uma clara coerência entre discurso e prática, tendo assim todo o mérito de valorização e atenção.

Também é na década de 1980 que se evidencia uma abertura aos concursos públicos para intervenção em centros históricos, concursos que freqüentemente acolhem uma visão meramente funcional do tema, principalmente no que diz respeito aos problemas de organização dos fluxos de circulação. A preponderância do problema funcional durante as intervenções intensifica o distanciamento do trabalho interdisciplinar e declara definitivamente o rompimento entre os elementos que caracterizam a complexidade do espaço urbano, o que resulta, em muitos casos, em cenários que violentamente depreciam a qualidade ambiental da cidade. Cabe dizer que a cidade é um espaço de encontro tanto de elementos oriundos de diferentes épocas como de

\footnotetext{
5 Os conceitos de continuidade assim como bem cultural adotados por Aloísio Magalhães a partir de 1979 com sua entrada no Sphan vêm da percepção da inadequação do modelo de desenvolvimento sócio-econômico que o país adotara então. 0 desenvolvimento desejado pelo governo pressupunha benefícios materiais sem nenhum tipo de crescimento interno como a herança identitária, no sentido de valorizar as nossas próprias riquezas e possibilidades. É nesse quadro político que se percebe a inadequação das instituições culturais do Estado para lidar com tamanha mudança estrutural do país. MAGALHÃES, Aloisio. E triunfo? A questão dos bens culturais no Brasil. Rio de Janeiro: Nova Fronteira; Brasília: UnB, 1987.

${ }^{6}$ Alguns projetos foram tombados posteriormente à sua intervenção, portanto intui-se que Lina consegue com a atribuição de um novo sentido ao edifício através de uma metodologia própria evidenciar também o seu valor histórico, ou melhor, o seu valor como objeto mnemônico em seu sentido pleno. O Sesc Pompéia é um exemplo significativo dessa compreensão.
} 
enfoques pluridisciplinares e este convívio revela-se na reinterpretação constante no presente. A escolha de um determinado enfoque provoca uma autoritária dissonância, escolha que, no caso dos arquitetos e urbanistas, tornase material e, portanto, tem a "vantagem" da perenidade.

Há que se considerar tais intervenções como um campo de convergência de diversas problemáticas de domínio público, o que provoca um encontro de interesses das distintas áreas como estudo. É dessa forma que áreas ligadas à arquitetura e ao urbanismo também se colocam em diálogo, principalmente sobre o escopo do espaço público e da preservação patrimonial. Por esse motivo, cabe destacar a importância de se estabelecer algumas conexões entre as trajetórias dos respectivos campos, suas nuances, estreitamentos e especificidades. 0 conhecimento aprofundado sobre estas áreas específicas e a proposta de evidenciar cada espaço intelectual não ambicionam criar uma linguagem unidirecional, anulando as diferenças, nem mesmo criar uma amostragem das diversas abordagens sobre um objeto em comum, mas sim permitir que se estabeleçam relações entre as práticas num processo controlado pelos limites metodológicos e científicos especíicos, a fim de se entender o objeto a partir de uma construção atual. Este enfoque ganha importância se considerarmos o objeto em questão "cidade" em sua complexidade, ou seja, apresentado sob uma lógica temporal plural, flexível e mutável. O espaço urbano existe através do encontro de diversas estratificações e, portanto, não caberia aqui fazer uma análise linear dos processos de transformação. Pode-se dizer, então, que a década de 1980 no Brasil, a partir de um contexto político de abertura democrática, caracteriza-se como um momento em que a discussão sobre a forma de trabalhar com o fator "pluralidade" é foco de discussão em várias áreas.

Nesse sentido, o recorte estabelecido no trabalho se define a partir da análise de dois projetos de intervenção urbana da arquiteta Lina nos anos 1980, onde os procedimentos envolvidos no trabalho de atuação, desde a fase de análise até a execução, dialogam diretamente com as questões aqui levantadas. O esforço em dar soluções funcionais somado ao entendimento das dinâmicas existentes diferencia o trabalho da arquiteta enquanto processo e possivelmente permite traçar um segundo caminho motivado por fundamentos que possibilitam estabelecer uma outra relação entre o antigo e o novo nas intervenções urbanas. 
O desejo de esclarecer o modo particular de atuação sobre a preexistência presente nas obras da arquiteta Lina provocou a necessidade de se investigar sua formação e experiência profissional apontando alguns momentos em que 0 tema da relação entre 0 antigo e o novo era evidenciado, o que estruturou 0 trabalho em praticamente duas partes: a primeira versa sobre o foco da formação da arquiteta e sua experiência profissional e, a segunda, dedicada à análise dos dois projetos escolhidos. Neste trabalho retrospectivo de sua formação e trajetória foi importante buscar algumas referências teóricas que prescindiam certas noções usadas constantemente por Lina, bem como contextualizar os momentos em que estas questões aparecem ,a fim de se construir um pensamento com mais distanciamento científico e menos "apaixonado" sobre o trabalho da arquiteta Lina.

Tratadas estas questões, principalmente aquilo que pressupõe 0 entendimento da relação entre 0 antigo e o novo em sua trajetória, 0 trabalho passa a ser desenvolvido a partir da análise dos dois estudos de casos representativos da questão levantada. No que se refere à seleção dos projetos, pressupôs-se a presença de determinadas condições imprescindíveis para a investigação tanto dos fundamentos estabelecidos pela profissional para o trato da questão do convívio existente entre 0 antigo e o novo quanto dos instrumentos por ela utilizados em sua prática. Em primeiro lugar, sua condição de intervenção urbana como dado a priori. Em segundo lugar, as condicionantes da manutenção do sentido de "bem comum" existente nestas intervenções. Em terceiro lugar, a própria consideração sobre as dinâmicas cotidianas como fator estrutural do projeto. Finalmente, o processo metodológico adotado, que é por si só narrativo destas preocupações, desde os desenhos de análise que as anunciam, até os discursos que convencem a execução. Logicamente, não se trata de estabelecer um comparativo entre os dois exemplos, mas mostrar as diferentes experiências materiais encontradas sob as condições teóricas de pesquisa, de modo que se possa traçar um quadro contrastante com outras atuações e ampliar as conclusões obtidas ao final.

Cabe colocar que os projetos têm visivelmente diferenças no detalhamento da análise, condicionado pela qualidade do material documental encontrado ou ainda pela impossibilidade de acesso às obras executadas. 0 Concurso: Vale do Anhangabaú, por exemplo, é um projeto que assume sua 
condição de "concurso de idéias" e, portanto, existem alguns croquis, aquarelas e apenas três pranchas de desenhos, as quais foram apresentadas no concurso. Além disso, não há quase nenhum material publicado sobre o projeto. Por outro lado, o Centro Histórico de Salvador, além de ser objeto de investigação em diversas pesquisas (citadas no decorrer do texto), tem partes do projeto executadas e é possível de ser visitadas ainda hoje. 


\section{PARTE 1}

0 antigo e o novo em lina bo bardi 


\section{1 formação e trajetória}

sensibilidade moderna

É relevante a quantidade de estudos sobre a formação da arquiteta Lina Bo Bardi e sobre 0 ambiente em que se insere durante o período acadêmico e seus primeiros anos de atuação profissional ${ }^{1}$. Assim, não é necessário repetir seu itinerário, já tão bem explorado por estudos recentes, mas sim colocar em evidência alguns momentos que interessam diretamente ao assunto aqui analisado. Desse modo, optou-se por abordar a formação da arquiteta enfocando três aspectos especialmente relacionados à discussão da relação entre 0 antigo e 0 novo em intervenções ocorridas em lugares tidos como representativos da memória coletiva. Primeiro, a formação romana de Lina a partir dos preceitos giovannonianos relativos à consideração do patrimônio urbano histórico e ao ambiente urbano; segundo, a importância da museologia na Itália no desenvolvimento da nova sensibilidade moderna e no enfrentamento da preexistência; terceiro, a discussão sobre a cultura popular como objeto de investigação referencial do desenho arquitetônico na proposição do novo.

Como contribuições importantes para a análise dos objetos empíricos aqui propostos para estudo, somam-se a estas características de sua formação algumas questões lançadas no segundo pós-guerra europeu, as quais contemplam o tema das intervenções urbanas tanto do ponto de vista das discussões internacionais promovidas por arquitetos e urbanistas como a partir da ótica da Teoria da Restauração. Por fim, considera-se importante comparar estas referências sobre as categorias culturais envolvidas com a realidade encontrada no Brasil.

\footnotetext{
${ }^{1}$ A formação de Lina, bem como o ambiente italiano do período dos seus primeiros trabalhos, é um tema bastante explorado nos estudos sobre a arquiteta. Destaca-se a colaboração do professor Renato Anelli (a quem agradeço a disponibilidade) e seus alunos orientandos. É possível verificar uma síntese deste trabalho em ANELLI, Renato Luiz Sobral. Interlocução com a arquitetura italiana na constituição da arquitetura moderna em São Paulo. Texto de sistematização da produção científica para o Concurso de Livre Docência - EESC - USP. São Carlos, 2001. Dentre outros, destaca-se: FERRAZ, Marcelo Carvalho (org). Lina Bo Bardi. São Paulo: Empresa das Artes; Instituto Lina Bo e P.M. Bardi, 1993; CABRAL, Maria Cristina Nascentes. Racionalismo arquitetônico de Lina Bo Bardi. Dissertacão de Mestrado, PUC- Rio de Janeiro, 1996; CAMPELLO, M. de Fátima de M. Barreto. Lina Bo Bardi: as moradas da alma. Dissertação de Mestrado, EESC USP. São Carlos, 1997. Apenas como lembrete, a forma "Lina Bo Bardi" é usada para iniciar a dissertação, mas no decorrer do texto usa-se apenas "Lina" para que a leitura fique mais fluida.
} 
A revisão da bibliografia sobre o contexto da formação da arquiteta na Itália configura uma tentativa dos pesquisadores brasileiros de entender sua trajetória através de uma conjuntura política e cultural diversa. Esta trajetória, apesar de abranger distintos campos de atuação, permite reconhecer um discurso linear da arquiteta sobre certos aspectos culturais - 0 que alguns autores caracterizam como uma "ação cultural", que vai além dos problemas específicos da disciplina arquitetônica. Neste sentido, é necessário pôr em relevo nos estudos de sua trajetória alguns elementos que apontam para a construção de um repertório cultural particular oriundo do contexto encontrado durante a sua formação na Itália e que posto numa situação diversa como a nossa pode conformar aproximações superficiais ou construir um diálogo aparentemente similar, mas que, na verdade, pertencem a categorias culturais específicas e totalmente distintas.

Em realidade, esta "ação cultural" apontada pela bibliografia procedente somente é legivel a partir da identificação de uma coerência no processo de trabalho desenvolvido pela arquiteta, entre seus princípios e a prática. Isto somente fica visível através de um distanciamento temporal entre as ações e a leitura de seus projetos de uma maneira ampla, uma vez que, mudando para uma escala mais "intima", Lina se contradiz frequentemente no plano argüitivo, o qual se modifica conforme $o$ contexto e as experiências adquiridas². A mudança de opinião não deve ser considerada um desregramento, ao contrário, deve ser vista como um processo crítico que contribui para as tomadas de posição assumidas pela arquiteta ao longo de sua carreira profissional. Postas estas contradições em evidência pública - na publicação de artigos de revistas ou mesmo nos projetos -, Lina transfere o problema e o coloca como reflexão, ou melhor, como exame crítico. Este amadurecimento intelectual não é, portanto, um processo solitário, mas aparece constantemente nas lembranças das pessoas de sua convivência diária, no modo como a arquiteta provoca e questiona afirmações que pouco antes haviam sido defendidas por ela mesma e que, num dado momento, circulam naturalmente nas discussões do escritório ou nas soluções encontradas em algum projeto. Este modo de ser provocativo e que foi entendido muitas vezes como "arrogância" funciona constantemente

2 Este fato é evidenciado principalmente nas entrevistas com as pessoas que trabalharam diretamente com Lina. 
como avaliação das idéias. Apesar de ser uma característica da própria personalidade da arquiteta - algo intuitivo e não uma questão colocada a priori -, este traço de personalidade acaba espelhando a sua preocupação com a necessidade de se formar nas pessoas uma postura crítica. Isto explica a negação da conciliação com certas linhas de pensamento e a importância dada à reflexão crítica, o que a coloca em paralelo com as vanguardas modernas e a preocupação com a questão do método ${ }^{3}$.

A relevância dada ao exame crítico tem como objetivo colocar sob a responsabilidade do arquiteto uma atitude moral, de construir problemas advindos da real necessidade de cada lugar e não apenas apresentar soluções emprestadas, que se mostraram adequadas em algum momento ou em outro lugar. Para Lina, seguir linhas de intervenções já estabelecidas significa aderir a uma mera abstração apontada pela arquiteta como insuficiente frente à complexidade da vida contemporânea.

"Neste século, a Arquitetura [...] perdeu seu caráter de arte como produto de fantasia e de regras fixas de linguagem, para se tornar uma arte que raciocina e se exprime mediante uma linguagem que não se funda em tais regras fixas, mas provém de emoções e práticas que emprestam novo caráter, imprevisto, ao seu desenvolvimento, em virtude mesmo das inovações da ciência, da técnica e do costume que, em nossos dias, se encontram em vertiginosa evolução. A extrema precariedade e rapidez com que flui a vida contemporânea, impedem a formação de um método estável de ensino, que seria superado, já em sua fase de formação."4

É dessa forma que o exame crítico estabelece uma outra relação com o ensino e a formação do arquiteto. 0 novo método buscado propõe uma outra aproximação com o passado, rompendo com normas pré-fixadas que até então condicionavam a produção da arquitetura. Isto não quer dizer que o exame crítico subestime a história ou o passado, mas sim que exige um rompimento metodológico na consideração do tempo linear: o passado não mais como modelo, mas como reflexão.

"Para se eliminar a cisão entre o presente e o passado, necessária se torna a consideração histórica do resultado arquitetônico ao qual hoje chegamos. Mas, admitindo embora uma continuidade histórica, será conveniente, ao professor, uma cautela extrema. Desenvolvimento histórico não significa, com efeito

\footnotetext{
${ }^{3}$ Sobre 0 assunto destaca-se o texto: Livrar-se de todo espírito acadêmico. CORBUSIER, Le. Precisões sobre um estado presente da arquitetura e do urbanismo. São Paulo: Cosac \& Naify, 2004, p.35-45.

4 BARDI, Lina Bo. Contribuição Propedêutica ao Ensino da Teoria da Arquitetura. São Paulo: Instituto Lina Bo e P. M. Bardi, 2002, p.38-9. (original tese apresentada no concurso da cadeira de Teoria da Arquitetura e Urbanismo da Universidade de São Paulo, setembro de 1957).
} 
'conciliação', e sim exame crítico profundo e sempre presente, no caso da arquitetura, indispensável para não se cair na abstração formalística [...] a consideração, baseada num método rigoroso, dos problemas dos vários países, problemas reais que devem ser resolvidos com meios efetivos e não com a crítica abstrata, trata-se ou não de interpretação espacial ou da forma." ${ }^{5}$ (grifo do autor)

Lina, através da constante consideração sobre o aspecto da formação afirma a vontade de uma nova cultura baseada na consciência histórica e, portanto, na aquisição de um novo método que devera concretize uma sensibilidade nova, moderna.

Pode-se dizer que consciência histórica implica em considerar 0 passado não como norma ideal, mas fazer o exercício de retirar-lhe a "razão de ser das coisas, a lição da história"6, como diz Le Corbusier. Apesar desta referência a Le Corbusier, baseada na vanguarda moderna sobre a discussão da abordagem crítica do passado, há que se considerar estes propósitos sob 0 ponto de vista da geração dos arquitetos do segundo pós-guerra, na qual a arquiteta Lina está inserida. A validade destas questões introduzidas pelas vanguardas modernas continua presente nas discussões da geração de arquitetos dos anos 1950, reafirmando o sentido crítico de suas ações. Isto significa dizer também que inclusive o passado mais próximo passa por uma avaliação - sobretudo sob os efeitos do aspecto "doutrinário" do próprio movimento moderno. Nesta direção, Lina alinha-se com os propósitos dos arquitetos do segundo pós-guerra, explicitamente críticos da validade dos princípios universais defendidos pelos arquitetos modernos da geração precedente.

É através do desenvolvimento de um método plausível para enfrentar a questão de cunho cultural que Lina se prepara para produzir a arquitetura de maneira crítica e libertar as possibilidades do arquiteto (entendido como aquele mediador responsável pelo modo de viver dos homens ${ }^{7}$ ). Acredita-se, então, que o processo crítico e o método são responsáveis pela qualidade da arquitetura e, da mesma forma, pela prosperidade do modo de se viver na cidade. Estabelece-

\footnotetext{
5 Op.cit., pp.69-70.

${ }^{6}$ CORBUSIER, Le. Livrar-se de todo espírito acadêmico. In: Precisões..., op.cit, p.44.

7 BARDI, Lina Bo. Contribuição..., op.cit., p.51. Lina define o método como "a capacidade de orientação, de estudo e de apreensão criadora do âmbito cognoscível necessário à ciência (em nosso caso a Arquitetura) e à vida, a fim de se chegar àquela auto-disciplina intelectual e autonomia moral que deveriam ser, sobretudo em sua fase inicial, prerrogativas da Escola, nunca abandonadas ao léu da vida prática." Idem, pp.57-58.
} 
se um estreito caminho entre produção e formação, o que é perseguido constantemente em seu trabalho.

O que a arquiteta busca na preocupação constante com o método é a possibilidade de imaginar uma coerência entre o novo modo de vida das grandes cidades e a produção arquitetônica e urbanística. Consequentemente, o processo de formação deveria inventar um novo movimento para a criação desta nova sensibilidade. Para Lina, a postura dogmática do ensino seria incongruente com as mudanças ocorridas na sociedade com 0 advento da modernidade ${ }^{8}$. A forma de se pensar e fazer a arquitetura moderna deveria ser também uma postura política, um desejo de mudança adquirido e reiterado na experiência da guerra vivida por Lina.

Esta questão não pode ser tomada como afeita apenas à arquiteta em estudo, pois o tema frequentemente vem merecendo a atenção de vários intelectuais. A questão do método é constantemente retomada por estudiosos de várias áreas porque em muitos momentos históricos existe certa incongruência metodológica entre realidade, meios produtivos e formação, ou seja, a razão é substituída por meros esquemas ou ações mecânicas já existentes. No caso, a geração do segundo pós-guerra reitera a preocupação com o método através de uma ótica renovada, ou seja, a própria produção moderna (fruto de um processo teoricamente crítico não convencional) estaria banalizada e ligada a um modismo apenas estético.

Silvana Rubino, em seu estudo sobre a modernidade - estimulado pela trajetória de Lina -, propõe uma revisão bibliográfica sobre o assunto. Rubino, ao discutir as idéias de Anthony Giddens faz uma colocação pertinente à discussão do método:

"Modernidade é quase equivalente à industrialização, se entendermos o mundo

\footnotetext{
${ }^{8}$ As mudanças ocorridas na sociedade são temas recorrentes neste período por ser um novo modo de se enfrentar a própria produção moderna. Destaca-se o estudo de Silvana Rubino que aponta o tema da modernidade - como manifestação na prática da arquiteta Lina sobre a ótica da teoria social. Silvana cita vários autores, dentre eles David Frisby e a retomada de Baudelaire nas obras de Simmel e Benjamin. RUBINO, Silvana Barbosa. Rotas..., op.cit. Otilia Arantes lembra que a mesma comparação entre Simmel e Benjamin é feita pela Escola de Veneza, na figura de Massimo Cacciari. A primeira referência introduzida por Otilia vem das revisões da Escola de Veneza sobre os desdobramentos da idéias do movimento moderno e o balanço das idéias colocadas sobre a vida metropolitana e seus problemas enfrentados sobre a ótica da experiência do capitalismo. Esse processo de investigação caracteriza a crítica marxista desenvolvida em revistas da década de 1960 e 1970 na Itália. ARANTES, Otília. A ideologia do lugar público na arquitetura contemporânea. In: O lugar da arquitetura depois dos modernos. São Paulo: Edusp, 2000, p. 97-151.
} 
industrial como mais do que sua dimensão institucional. Seu sinal diacrítico, tradição, é uma forma de se lidar com o tempo e espaço que insere toda a experiência dentro da continuidade do passado, presente e futuro. $\underline{A}$ modernidade não justifica suas práticas pela tradição mas pelo conhecimento. Nas palavras do autor, há uma 'revisão da convencão'. E se modernismo é reflexão estética sobre a natureza da modernidade, o é também em relação a suas práticas espaciais e temporais"9(grifo nosso)

Em 1957 Lina prepara sua tese Contribuição Propedêutica ao Ensino de

Teoria Arquitetura juntamente com o programa do curso de extensão universitária para um concurso na Faculdade de Arquitetura de São Paulo. Lina fala exatamente do problema do método. ${ }^{10}$

"[...] A tarefa do professor deveria ser a de despertar a consciência crítica, dando ao estudante o sentido da continuidade da história, não como elegância cultural, mas como fonte viva de contribuições reais. 0 jovem arquiteto não encontrará de estarte, sua segurança, em noções aparentemente certas e provadas, mas em sua incerteza, em sua timidez perante as responsabilidades de ordem moral que ele intui na profissão, encontrará naqueles princípios, a força para se orientar, a lucidez crítica necessária ao profissional de hoje, consciente de que não the é lícito abandonar-se a orgias exibicionistas, devendo antes encontrar, em sua responsável humanidade, o único prêmio de seu esforço." ${ }^{11}$ (grifo do autor)

Como já colocado anteriormente, eliminar a defasagem entre modo de vida moderno e o modo de percebê-lo é um desafio ressoante das vanguardas européias artísticas e que determinam discussões nos períodos subseqüentes. Estas discussões fazem apologia a uma nova noção de tempo, da história, e ainda, da relação entre a cultura e a técnica - o que devemos detalhar no decorrer do texto ${ }^{12}$.

Não parece acaso que Lina rememore a constante procura de novas possibilidades de método de ensino no trabalho do arquiteto alemão Walter Gropius. ${ }^{13}$ Como bem relembra Ignasi de Solà-Morales sobre 0 ambiente alemão, "en ningún otro ambiente cultural europeo el poder técnico ha sido percibido y pensado con acentos a la vez fantásticos y trágicos como entre los intelectuales alemanes del primer tercio de nuestro siglo."14. Gropius retoma 0 tema em praticamente todos os Congressos de Arquitetura Moderna (CIAM).

\footnotetext{
${ }^{9}$ GIDDENS, Anthony apud RUBINO, Silvana Barbosa. Rotas..., op.cit., p.7.

${ }^{10}$ BARDI, Lina Bo. Contribuição..., op.cit., p.38-9.

${ }^{11}$ Idem, p.38-9.

12 Sobre 0 assunto, destaca-se 0 texto sobre os conceitos básicos que determinam a obra de Siegfred Giedion. SOLÀ-MORALES, Ignasi. Siegfred Giedion: la construcción de la historia de la arquitetura. In: Inscripciones. Barcelona: Gustavo Gilli, 2003, p. 217-225.

${ }^{13}$ BARDI, Lina Bo. Contribuição..., op.cit., p.56.

${ }^{14}$ SOLÀ-MORALES, Ignasi. Siegfred..., op.cit, p.223.
} 
Fica evidente nessa passagem de Siegfried Giedion, fazendo as considerações finais sobre o VIII CIAM em 1951, a importância do tema da educação colocada por Gropius ${ }^{15}$ :

"Él tema de la educación architectónica, del que tantas vezes se ha ocupado el CIAM, fué abordado nuevamente en Hoddesdon. Sería imposible encontrar una expresión más noble de dicho problema que la formulada por Walter Gropius [...]: 'La ley suprema de la educación está en suprimir la super-especialización a favor de la plenitud de conocimientos. La acumulación de fórmulas y hechos detallados debe dejar paso a la sabiduría del método."'16 (grifo nosso)

\section{o ambiente urbano na formação do arquiteto}

Lina cursa a Faculdade de Arquitetura em Roma na década de 1930 na Itália fascista. Há que se considerar o peso desta formação romana para a discussão aqui proposta, principalmente pela relevância que a discussão sobre a relação entre 0 antigo e o novo em intervenções urbanas tem nesse momento na Itália - a inovação funcional proposta pela conjuntura política e a necessidade de se apreciar a tradição estética como identidade importante do regime fascista. Outro dado preponderante é a inserção da escala urbana como problema a ser enfrentado nos dois aspectos já citados: funcionais e memoriais. Nesta direção, surge como tema central a questão dos centros antigos e do designado "patrimônio histórico urbano"17. Protagonista desta reflexão na Itália é Gustavo Giovannoni, professor de Lina e figura principal na concepção da Escola de Arquitetura em Roma.

Antes de adentrar o campo da formação da época em que Lina estuda em Roma, necessário se faz o entendimento da noção empregada aqui: patrimônio histórico urbano. Esta noção está diretamente ligada à importância do 'valor artístico' na vida urbana e consolida praticamente uma genealogia da discussão entre o antigo e o novo da qual Giovannoni faz parte. É fruto do "confronto" declarado entre permanência/inovação, quando "uma nova ordem é criada, segundo um processo tradicional de adaptação da sociedade que habita

15 Giedion, na ocasião do VIII CIAM, já apontava algumas considerações responsáveis pelo problema metodológico estabelecido então na construção de lugares. Com isso tenta restabelecer o tema do monumento e seu valor simbólico como meio para unificar novamente arquitetura e comunidade na cidade industrial.

16 GIEDION, Siegfried. El Corazón de la ciudad: resumen. In: ROGERS, E. N., SERT, J. L., TYRWHITT, J. El corazón de la ciudade? Por una vida más humana de la comunidad. Congressos Internacionales de Arquitectura Moderna. Barcelona: Hoepli, S.L., 1955, p.160.

17 Termo cunhado por Françoise Choay In: CHOAY, Françoise. A Alegoria do Patrimônio. São Paulo: Estação Liberdade / Ed. Unesp, 2001, pp.175-205. 
nela"18. Este processo está ligado à adaptação das cidades às transformações da sociedade: à medida que vai se intensificando e ganhando forma, a nova ordem provoca um movimento de estranhamento e de reflexão. E na verdade, ainda que se manifestem de maneira distinta, de acordo com o grau de transformação e percepção, e apareçam sob enfoques diversos, as reflexões sobre as transformações nas cidades são mesmo anteriores à própria consolidação do urbanismo como disciplina. Nesse sentido, é fácil entender porque é na Europa - especificamente em cidades com um grande peso histórico e heranças artísticas das civilizações remotas - que a preocupação com esta questão fica mais evidente ${ }^{19}$.

"O mundo acabado do passado perdeu a continuidade e a homogeneidade que Ihe conferia a permanência do fazer manual dos homens. 0 monumento histórico adquire com isso uma nova determinação temporal. Doravante, a distância que dele nos separa se desdobra. Ele está refugiado num passado do passado. Tal passado já não pertence à continuidade do devir e a ele nada será acrescentado pelo presente ou pelo futuro. E qualquer que seja a riqueza dos filões arqueológicos ainda inexplorados, essa fratura do tempo relega o campo dos monumentos ao canto de uma finitude inapelável." ${ }^{20}$

Apesar das intermináveis reflexões sobre a cidade, em seus mais variados aspectos - principalmente para a história das mentalidades -, o objeto em si 'cidade' não era imaginado até então como um patrimônio que pudesse ser tratado como monumento, com a respectiva prática de conservação. No entanto, a historiadora francesa das teorias das formas urbanas Françoise Choay resgata alguns indícios de que esta perspectiva já se fazia presente.

É importante reafirmar que a discussão travada entre 0 antigo/novo nas cidades não significa uma tentativa de apenas preservar a cidade antiga; 0 estudo urbano e a história do urbanismo não se confundem com a invenção do patrimônio urbano histórico e a necessidade de sua proteção, apesar da dependência recíproca. A tarefa de organizar o espaço urbano eleva a cidade a objeto de investigação e este estudo adquire o nome de urbanismo. No entanto, essas transformações no interior da proposta de destruir ou preservar com a finalidade de obter uma nova organização urbana causam reações em prol das formas antigas. Conforme Choay, esta noção chama-se patrimônio urbano

${ }^{18}$ CHOAY, Françoise. O Urbanismo. São Paulo: Editora Perspectiva, 1997, p.4.

${ }^{19}$ A França e a Grã-Bretanha são lugares onde a questão aparece com mais afago. Sobre 0 assunto ver CHOAY, Françoise. A Alegoria..., op. cit., p.137.

20 Idem, p. 136. 
histórico. Define-se pela reação ao processo de urbanização e origina-se com John Ruskin na incisão das intervenções sobre a malha das cidades antigas. Esta preocupação aparece em seus escritos na ocasião da descoberta de que arquitetura doméstica confere à cidade a beleza única no seu conjunto, indiscutivelmente superior ao monumento isolado.

"Este espíritu de valiente, noble y tranquilo dominio de sí mismo, esta inmutable conciencia de una vida satisfecha, es verdaderamente, a mi parecer, una de las principales fuentes de gran fuerza intelectual en todos los periodos; ella há sido incontestablemente la fuente primitiva da gran arquitectura antigua en Itália y en França. En nuestros mismos dias, el interés de la más bellas de sus ciudades depende, no ya de la riqueza aislada de sus palacios, sino de la exquisita y celosa decoración de las habitaciones, aun en las más pequeňas de sus orgullosas épocas."21

Se pensarmos na definição de monumento ${ }^{22}$ - no sentido de instrumento mnemônico que traz o passado para o cotidiano presente enquanto forma de apresentação espontânea -, o conjunto das "arquiteturas menores" e o modo de fazê-las e usá-las são verdadeiramente fontes de memória coletiva. Ruskin acredita que o simples fato de não deterem instrumentos que os assegurem como "monumento" e que, portanto, existem por vontade espontânea, estes conjuntos são as reais fontes de memória. Ou seja, o conjunto destas "arquiteturas menores" confere significações cotidianas e um sentido de pertencimento capaz de se auto designar "monumento". No entanto, ao mesmo tempo em que o autor revela o conjunto como detentor da verdadeira memória, circunscreve-o num limite impenetrável. Esconjura qualquer tipo de intervenção transformadora no modo de habitá-lo porque a arte que o desenhou exprime aquela determinada sociedade, sendo assim impossivel enquadrar outro modo de vida senão aquele que o originou. Apesar de evidenciar os câmbios na cidade e predizer a forma stantard que elas teriam que enfrentar, Ruskin acreditava que estas mudanças ocorreriam em lugares ainda inóspitos ou naqueles mundos que não têm a tradição nem o enfretamento da preexistência.

${ }^{21}$ RUSKIN, John. Las siete lámparas de la arquitectura. Buenos Aires: Librería El Ateneo Editorial, 1956, p.240. A mesma preocupação é evidente na obra anterior The Stones of Venice de 1897.

22 Conforme Alois Riegl existe uma diferença entre monumento (monumento intencionados) e monumento histórico. Monumento é uma criação intencional do homem com o intuito de da possibilidade de conservar sempre viva a memória de um determinado povo. Monumento-histórico surge durante a intenção de proteger algumas obras, ou seja, não é obrigatoriamente ligada à memória viva e coletiva mas ao valor histórico-artístico. RIEGL, Alois. Le culte moderne des monuments. Son essences et sa gênese. (Trad. Daniel Wieczorek). Paris: Seul, 1984, p. 41. Sobre o tema ver também CHOAY, Françoise. Alegoria..., op.cit, p.11. 
São duas formas de sociedade que não se configuram materialmente num mesmo espaço; duas cidades distintas que devem ser respeitadas. Portanto, a visão torna-se extremamente conservadora, na medida em que estabelece a cidade pré-industrial como aquela pertencente a um passado fechado, intransponivel.

Outra postura reticente à dialética antigo/novo sobre a cidade é a do historiador austríaco Camillo Sitte em sua obra Der Städtebau de 1889. Apesar das declarações equivocadas de Le Corbusier ${ }^{23}$ sobre a "vocação passadista" de Sitte, é notória a sua postura positiva frente às possibilidades de transformação dirigidas por princípios contingentes à cidade antiga. Sitte não é contrário às ações então vigentes nas intervenções da cidade do fim do século XIX; reconhece-as como avanço conquistado em relação aos problemas presentes na urbe: 0 tráfego, as pestes e a insalubridade em geral. "Em termos gerais, todavia, pode ser considerado um reconhecimento unânime e respeitoso dos muitos êxitos técnicos alcançados no âmbito do tráfego, do aproveitamento lucrativo dos terrenos construídos e, sobretudo, das grandes melhorias sanitárias." ${ }^{24}$

Fica evidente que Sitte não condena tais práticas, mas as considera como fator evidente enquanto suporte para a vida nas cidades até então inchadas e insalubres. Estes avanços técnicos adquiridos acontecem pela busca de soluções frente aos problemas enfrentados e, supostamente, esta confrontação seria absolutamente necessária num determinado momento. No entanto, o que o autor rejeita é a tentativa de rompimento da continuidade morfológica que prevalecia até então na tradição, considerada instrumento fundamental na construção da cidade.

"[...] em contrapartida, nota-se também uma condenação, por uma unanimidade que chega às raias do desprezo e do escárnio, dos fracassos estéticos da construção urbana moderna. Trata-se de uma avaliação

\footnotetext{
${ }^{23}$ A celeuma gerada entre a obra de Sitte e os modernos acontece através da leitura da tradução francesa de 1902, feita por Camille Martin. As críticas aos ideais sitteanos serão colocadas de forma explícita no livro Urbanismo de Le Corbusier. Uma das advertências que Le Corbusier faz em sua obra diz respeito ao enfrentamento otimista e entusiasta da sociedade transformada, o que leva a crer que seu objetivo era dar uma resposta ao enfrentamento "derrotista" que até então se configurava sobre as ações na sua época. CORBUSIER, Le. Urbanismo. São Paulo: Editora Martins Fontes, 1992.

${ }^{24}$ SITTE, Camillo. A construção das cidades segundo seus princípios artísticos. São Paulo: Ed. Ática, 1992, p.11.
} 
procedente, pois, de fato, muito foi realizado sob o ponto de vista técnico, mas quase nada sob a perspectiva da arte [...]"25

Com esta preocupação, Sitte empenha-se em deixar disponível uma série de observações sobre as cidades européias e seus "efeitos preciosos". Ele afirma que sua obra não convenciona regras de construção urbana, mas faz lembrar, através de algumas indagações, um assunto esquecido: a continuidade presente na sabedoria de construir cidades segundo princípios artísticos. Ou seja, não ambiciona ser lei ou regra, mas provocar uma discussão entre os intelectuais envolvidos com esta prática - os quais se tornaram mecânicos e operadores de traçados saneadores. Sua análise volta-se para a descoberta de algumas disposições, consideradas em principio aleatórias, mas que traduzem algo contínuo na arte de construir as cidades. Seu diagnóstico provoca a descoberta da morfologia urbana através de características constantes diagnosticadas na observação de diversos espaços públicos considerados importantes desde as cidades antigas até as cidades barrocas. À visão passadista difundida sobre a sua figura contrapõe-se sua busca constante pela construção de uma linguagem contemporânea que mantenha a beleza e a admiração provocada por estas cidades antigas nos homens. Conforme lembra Choay ${ }^{26}$, Sitte tem a nítida consciência do seu tempo, da impossibilidade de imitar ou reproduzir a cidade antiga, pois são "configurações que correspondem a condições sociais desaparecidas e hoje desprovidas de sentido". Para Sitte a única saída para combater a brutal monotonia contemporânea das cidades seria re-conquistar a liberdade de usar métodos artísticos dos mestres antigos através da racionalidade histórica e da consciência crítica do passado. A configuração racional postulada pelo autor de Der Städtebau é o papel propedêutico aos arquitetos urbanistas contemporâneos.

Apesar das diferentes abordagens, consideram-se semelhantes os resultados implícitos nos discursos de Ruskin e Sitte. As estruturas apontadas por Sitte permitem resolver pontualmente sua adequação com a cidade moderna ainda que de forma bem limitada. A ação claramente conservadora de Ruskin não deixa de estar ainda presente na tarefa deixada por Sitte. Aponta-se 0 problema e a preocupação de tutelar estes bens, contudo este aporte não

25 Loc. cit.

${ }^{26}$ CHOAY, Françoise. A Alegoria..., op. cit., p.182-191. 
subsidia uma ação prática politicamente qualificada. Aponta-se apenas o papel restrito das cidades antigas: seu valor artístico e histórico.

Na Itália, é no início do século XX que estas preocupações entram em cena. Giovannoni, em meio às preocupações com os processos de renovação urbana durante 0 século XIX, propõe uma outra abordagem mais conciliatória e que exige a desconstrução das duas condições tidas como opositoras: a vida para o renovador e a história para o restaurador. "[...] determinare i rapporti tra l'ambiente antico e lo sviluppo nuovo: per l'uno, ove si escludano le opere d'importanza singolare ed i monumenti altamente venerandi, tutti $i$ resti del passato non rappresentano che 'ostacoli" nella nuova sistemazione edilizia, per l'altro sono invece 'capisaldi' immutabili."27

Giovannoni acredita na possibilidade de atender estas duas condições tratadas como "opostas" através de uma postura respeitosa entre as partes e tomando como partido ordens e critérios distintos. Acredita que o processo se inicia através do aprofundamento tanto das exigências reais da cidade como do respeito à arte e à memória coletiva, resultando então numa postura de transição. Esta visão vem da observação de que são raras as cidades que não enfrentam a dialética antigo/novo; são raras as cidades que surgem sem um núcleo já existente, como também são raras, quase inexistentes, as cidades que se mantêm com as mesmas características antigas.

Giovannoni parte para a tarefa de entender as características de cada modelo: da cidade antiga e da cidade nova. Admite que a cidade antiga tenha em si um valor artístico e histórico que não pode e nem deve ser desprezado. É inadmissivel, portanto, impor uma nova ordem que anule estas características através de uma planificação. As ações na cidade antiga devem assistir suas características originais, relativas ao seu valor de monumento coletivo e também sua atribuição de uso. Do outro lado está a cidade moderna e seus problemas demográficos, sua ordem econômica dinâmica e seu caráter veloz (organismo 'cinemático', expansivo e de rápida comunicação). Giovannoni dá um passo à frente em relação às discussões iniciadas por Sitte e orienta o que é o mais próximo ao que se preconiza nas ações da atualidade. 0 que se estabelece como solução possível para o diálogo da cidade moderna com este "patrimônio urbano" é uma concepção dual: uma ação que emerge de duas escalas distintas

${ }^{27}$ GIOVANNONI, Gustavo. Vecchie città ed edilizia nuova. In: Nuova Antologia, 1913, p.450. 
e que são associadas entre si a partir de uma sistematização do território em sua totalidade. É desta organização urbana do território que a parte antiga desenha seu sentido e seu valor. Giovannoni acredita na mudança de escala no urbanismo como técnica eficiente para tratar as diversas partes das cidades. É dessa forma que o componente antigo, com suas características específicas, é tratado como as outras partes da cidade, as quais também apresentam determinantes particulares.

"Non cosi doveva porsi il problema: poichè il voler far penetrare a forza la massima intensità di vita moderna in un organismo edilizio fatto con antichi criteri è voler acuire in modo insanabile il dissídio tra due ordine essencialmente differenti, non risolverlo. La via da seguirsi deve essere, quando é possibili, un'altra: sfollare il Vecchio núcleo cittadino, impedendo che il nuovo sviluppo edilizio reagendo su di esso venga ad attriburgli una funzione a cui è totalmente inadatto, porlo fuori delle grandi linee del traffico, rurlo ad un modesto quartiere misto di case d'affari e di semplici non ricche abitazioni. Solo allora una sistemazione locale, sapientemente ideata e pazientemente posta in atto, potrà in ques'antico abitato portare, caso per caso, oppotune transazioni tra i nuovi desiderata e le condizioni relative al passato" 28

Outro fator apontado nesta visão é a possibilidade de expansão, logo, de fragmentação da cidade. É exatamente a fragmentação que admite a cidade no seu global e particular juízo, recuperando a atualidade e característica de cada núcleo.

Esta atitude conciliatória é freqüentemente tratada como resultado de sua formação ampla - que admite os problemas enfrentados pelo patrimônio urbano, principalmente aqueles levantados em infinitas discussões sobre 0 sentido da cidade antiga como organismo estético, ao mesmo tempo em que procura trabalhar questões referentes ao urbanismo e à indiscutível necessidade de renovação das cidades. Esta iniciativa intermediária se alinha com a tendência proveniente da Teoria da Restauração, principalmente do restauro científico na figura de Camilo Boito - o que explica muitas soluções emprestadas para o conjunto urbano29.

A partir desse pressuposto, a visão de patrimônio urbano e o tratamento dessas áreas antigas não podem ser desvinculados do plano diretor em suas diferentes escalas, o que restabelece a noção de memória e sua condição de

28 Idem, p.460.

29 Giovannoni foi o responsável por recuperar do ostracismo os preceitos postos por Boito no séc. XIX para disciplinar a restauração, culminando na corrente conhecida como restauro científico ou filológico. 
monumento ${ }^{30}$. Conforme Choay "nesse sentido, seu valor de uso é legitimado, ao mesmo tempo, do ponto de vista técnico, por um trabalho de articulação com as grandes redes primárias de ordenação, e do ponto de vista humano, "pela manutenção do caráter social da população"'31.

A preocupação de Giovannoni extrapola os termos teóricos da discussão, o que é notável em sua militância contra o arrasamento das cidades, a participação em planos diretores e principalmente na difusão de suas idéias. Sua concepção dual baseada na crença de construir um país moderno não significa distanciar-se das tradições - principalmente daquelas condições ambientais particulares que conservaram a característica própria das cidades italianas, em especial advindas da "arquitetura menor", e a continuidade compositiva herdada. Suas idéias são as bases metodológicas para a concepção da Escola Superior de Arquitetura de Roma que prevê uma formação aparelhada por disciplinas técnico-científicas bem como histórico-artísticas ${ }^{32}$. A nova figura originada deste novo ordenamento didático é conhecida como arquiteto integral, homem da arte e da técnica33.

É importante entender a concepção do arquiteto integral proposta por Giovannoni como estratégia de inserção do regime fascista. A idéia de se formar um profissional "híbrido" - pela capacidade de entender uma exigência representativa somada à necessidade de coordenar uma política setorial do poder econômico e político - corresponde a uma necessidade política daquele momento. Conforme Giorgio Ciucci, o que faz esta aproximação é exatamente

30 GIOVANNONI, Gustavo. Vecchie..., op.cit. Em especial o capítulo "La città come organismo estético". Retoma-se a preocupação atual de Argan: E nossos técnicos, estão preparados para enfrentar os problemas da cidade, a qual encontra na arte seu fator unitário, ou têm competência para esta troca interdisciplinar? "Podemos dizer que nossas escolas de história da arte preparam estudiosos capazes de participar de equipes de projetistas, de colaborar no estudo dos processos vitais da cidade, e não somente de colocar obstáculos e limites, os quais têm, com certeza, sua razão de ser, mas apenas na medida em que os pontos da conservação sejam subordinados a - e, de certa forma, garantidos por - um tipo de cultura urbana que não repudie a própria historicidade mas dela tenha consciência?"ARGAN, Giulio Carlo. História..., op.cit.

${ }^{31} \mathrm{CHOAY}$, Françoise. A Alegoria..., op. cit. p.200.

$32 \mathrm{Um}$ exemplo elucidativo das idéias de Giovannoni colocadas em prática é a proposta para 0 bairro renascentista de Roma. GIOVANNONI, Gustavo. Proposte di sistemazione edilizia del quartiere del Rinascimento in Roma, 1916.

33 Sobre o assunto destaca-se ANELLI, Renato Luiz Sobral. Interlocução..., op.cit., p.64. Este tema é tratado em sua tese de doutorado baseado no estudo de ZUCCONI, Guido. Lá citta contesa: dagli ingegneri sanitari agli urbanisti (1885-1942). Milano: Editoriale Jaca Book, 1989 (Agradeço a gentileza do professor Renato Anelli pela disponibilidade da bibliografia). Ver também CAMPELLO, Maria de Fátima. Lina Bo..., op.cit., p.38. O livro Questioni di architettura nella storia e nella vita é uma sistematização das propostas e discussões didáticas para a metodologia de ensino da Escola Superior de Arquitetura em Roma. GIOVANNONI, Gustavo. Questioni di architettura nella storia e nella vita. Roma: Società Editrice d'Arte Illustrata, 1925. 
"L'Edilizia come forma della città e l'urbanística come modelo per il território34, em outras palavras, o arquiteto integral assume na sua formação a responsabilidade da reorganização da presença do Estado e da racionalização da intervenção fundiária através da formação generalista: da casa à cidade ${ }^{35}$. 0 arquiteto integral é aquele ao mesmo tempo artista, técnico e pessoa culta possível através da síntese entre a formação do engenheiro da Politécnica - um cientista - e da Academia de Belas Artes - um humanista.

A este momento apontado como meio para discutir a relação entre 0 antigo e o novo - fundamental no trabalho de mestrado - pode-se dizer que está ligado um ideal político. Segundo Ciucci ${ }^{36}$, apesar do regime mostrar-se ideologicamente heterogêneo ao assimilar conotações diversas na área ligada à

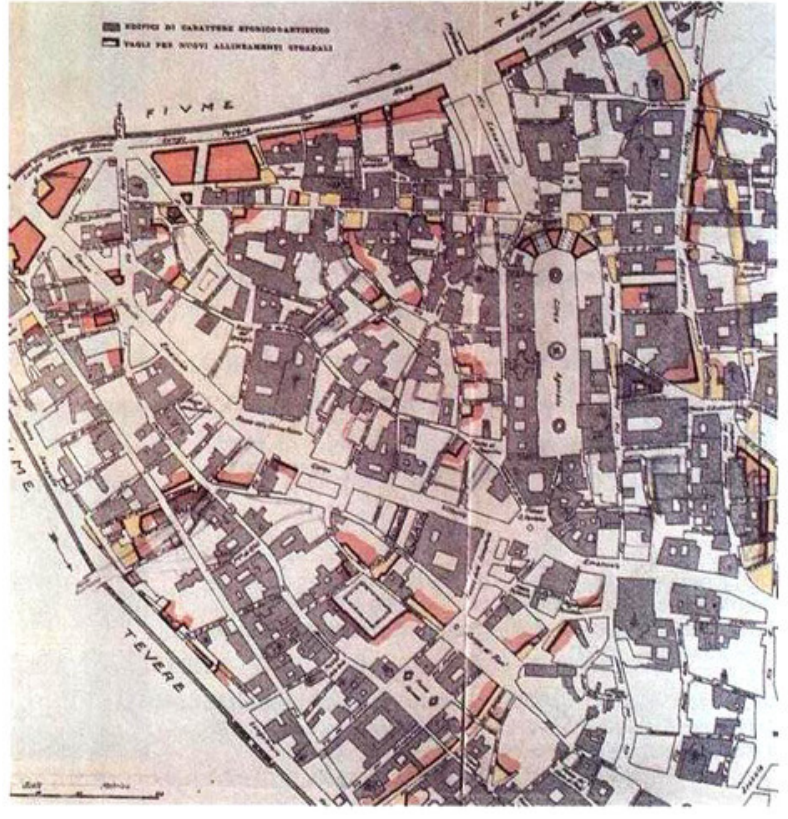

Fig.1 Sistematização de G. Giovannoni para o Quartiere del Rinascimento, em Roma, segundo o princípio do diradamento. São indicadas em amarelo as demolições; em laranja as reconstruções totais ou parciais; em preto, o novo alinhamento das ruas. estética, a idéia giovannoniana do arquiteto integral é aquela que assume diretamente 0 ideal fascista.

Tanto Giovannoni como Marcello Piacentini, professores de Lina, estão envolvidos com a Roman Associazione Artística fra i Cultori de Architettura e defendem discussões acerca das intervenções nas cidades baseadas em idéias inspiradas no Movimento Cidade Jardim, em Camillo Sitte e na importância da arquitetura vernacular ${ }^{37}$. A principal idéia que os unifica é que a cidade antiga tem uma identidade que não deve ser alterada pela transformação do tecido histórico. No entanto, os professores acreditam em procedimentos diversos. Giovannoni crê que através da técnica do diradamento a cidade antiga pode criar situações novas. Esta técnica consiste num tipo de "esfolamento" discreto (pequenas demolições) do centro velho a fim de reduzi-lo a um modesto bairro misto de casas de negócios e simples habitações. Significa a requalificação econômica daquela área operando através da destruição considerada "cirúrgica" da parte antiga.

\footnotetext{
34 Nome de um capítulo do livro de Giorgio Ciucci. In: CIUCCI, Giorgio. Gli architetti e il fascismo: architettura e città 1922-1944. Torino: Giulio Einaudi Editore, 1989.

35 Giovannoni chama a Escola de Roma de "um fascismo em antecipação" e poucos anos depois nasce na escola "o ponto de partida da vasta política arquitetônica do Fascismo". Idem, p.10.

${ }^{36}$ Idem.

37 ETLIN, Richard A. Modernism in italian architecture, 1890-1940. Cambridge, MIT Press, 1990, apud CAMPELLO, Maria de Fátima. Op.cit. Ver também GIOVANNONI, Gustavo. Questioni.., op.cit.
} 


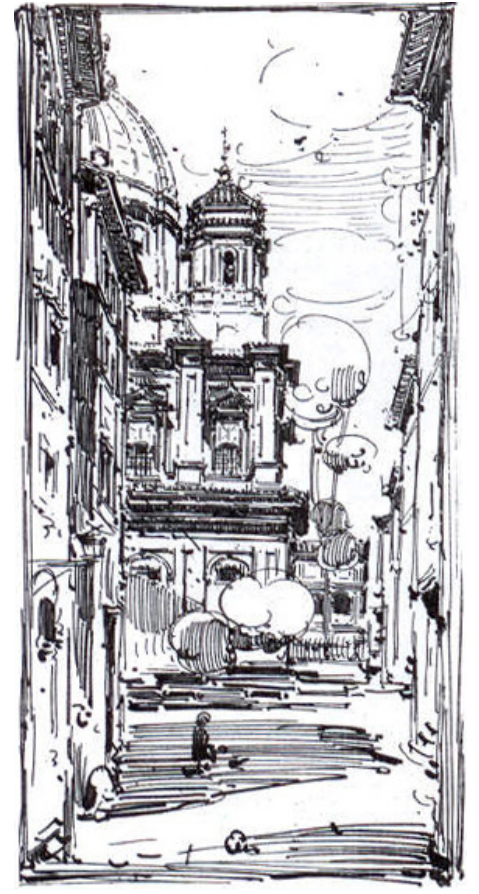

Fig.2 Croqui esquemático de $\mathrm{G}$. Giovannoni mostrando a nova perspectiva da via dei Coronari depois da aplicação do método do diradamento. Quartiere del Rinascimento, Roma.
Diferentemente de Giovannoni, Piacentini concebe a intervenção da seguinte maneira: "Iasciamo la città cosi, come si trova e sviluppiamo altrove la nuova"38. Ou seja, a cidade antiga é concebida como um lugar que não deve ser tocado em nenhuma hipótese, consolidando uma visão da cidade fragmentada, onde a parte antiga contém em si um "valor" que a nova não tem. Esta visão retoma a postura ruskiniana do passado incongruente com o presente e resulta exatamente na concepção do termo "centro histórico", ou seja, aquela única parte da cidade que proporciona a expressão da cultura urbana ${ }^{39}$. 0 passado ganha um valor qualitativo maior que o presente. Consequentemente, esta idéia terá desdobramentos gravíssimos com destruições irreversíveis de inúmeras partes da cidade.

Retomando então a formação de Lina, pode-se considerá-la, esta formação, como uma continuidade da concepção de arquiteto integral elaborada por Giovannoni, que pressupõe uma visão ampla da arquitetura, já que no conjunto da cidade encontram-se vestígios da identidade italiana. Assim, a renovação urbana implica num profundo conhecimento da paisagem e da vocação do lugar para que se possam eleger edifícios e modos de usar que devem prosperar ou não. Neste sentido, a formação romana de Lina confere-lhe uma alta capacidade filológica de análise do meio. Como podemos perceber no decorrer do texto, esta ação sobre o existente é extremamente fundamentada numa análise científica que dialoga abertamente com o campo da restauração e, no caso, tem como fundamento algo que resulta numa proposta considerada "cirúrgica".

Como contraponto desta revisão sobre o patrimônio histórico urbano existe a abordagem sobre 0 antigo/novo advinda do urbanismo da década de 1930 - contemporânea à formação de Lina. Esta outra abordagem ajuda a desenhar um quadro mais complexo sobre as discussões daquele momento a respeito das distintas vertentes da arquitetura e do urbanismo em relação à nova forma de projetar. Portanto, não há como deixar de lado a ideologia fundadora da cidade que propõe a "tabula rasa" como resposta, inclusive, por sua considerável repercussão. A proposta emblemática deste discurso é o Plan

\footnotetext{
${ }^{38} \mathrm{CIUCCl}, \mathrm{G}$. Op.cit, p.19.

${ }^{39}$ Ver ARGAN, Giulio Carlo. História da..., op.cit, p.79.
} 


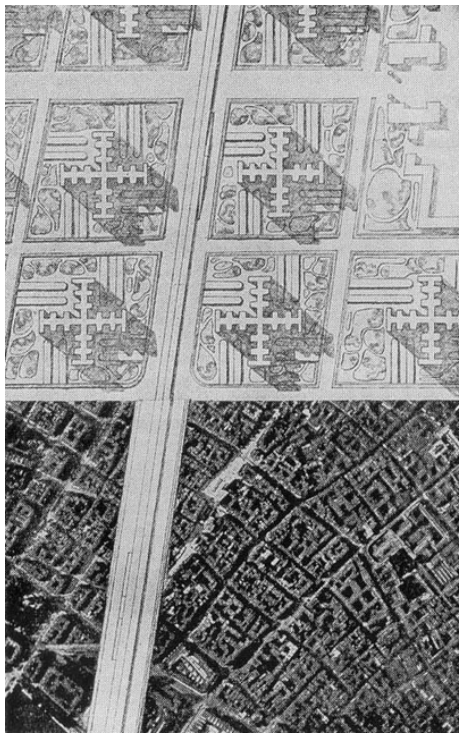

Fig.3 Plan Voisin para Paris de Le Corbusier.
Voisin de Le Corbusier, de $1925.4^{\circ}$ A continuidade tão referenciada até agora pelos autores que levam em consideração os princípios herdados na construção das cidades é encarada de outra maneira. Muito mais otimista frente às transformações que a máquina nos oferece, a unidade desejada somente se constituiria na medida em que a própria arquitetura e urbanismo se integrassem fielmente aos meios da vida moderna. Para isso a arquitetura e o urbanismo teriam que ser vistos como indissociáveis ou partes fundamentais da nova situação de vida: objetiva, racional e de exatidão.

Muito além do uso das novas técnicas disponíveis, Le Corbusier persiste na busca de uma outra visão de espaço que acompanhe o novo ritmo performático da vida cotidiana. Le Corbusier corrobora com o sistema industrial e a sociedade de massa existente, afirmando um novo programa para a arquitetura e 0 urbanismo. Paris é escolhida para materializar o que já havia concebido três anos antes no seu "Projeto para a Cidade de Três Milhões de Habitantes", apresentado em 1922 no Salão de Outono de Paris. Nesta cidade, as torres isoladas parecem alfinetes sobre uma indiferente superfície horizontal. Outra perspectiva, sobre o centro da cidade, mostra os arranha-céus se organizando entre o verde eventual da copas das árvores e a massa vegetal no horizonte. Seu novo instrumento não poderia ser outro que não a geometria: a cidade moderna acedia a linha reta e a racionalização que facilite a ordem da engenharia e da indústria - a canalização, a circulação, a moradia para todos. Espera-se uma prosperidade da nova ordem.

O que poderia ser de fato a visão de ruptura com a continuidade vigente da morfologia urbana e da culminância da representação do novo, na verdade, se contradiz. Essa malha ortogonal de grandes dimensões não se reproduz em escala menor. Enquanto a escala maior é pitagórica e geométrica, a escala do indivíduo que vive e usa a cidade aparece formalmente como um jardim pitoresco. Contrapõem-se duas ordens geométricas.

"El ejemplo propuesto aquí es paradigmático. La cultura moderna enfrenta la concepción del espacio público de la ciudad moderna con el diseño de estos espacios en la ciudad clásica. La ruptura epistemológica entre vieja y nueva civilización es también formal. Y, por ello, la contraposición de geometrías en el proyecto de Le Corbusier nos aparece como la imposibilidad de reunir algo que, en el arquitecto suizo, era todavía un intento desesperado: la unidad del

${ }^{40}$ LE CORBUSIER. Urbanismo, op.cit. 
mundo clásico representada por la regularidad de la geometría de las formas y la aleatoriedad del mundo moderno representado el repertorio pintoresco."41

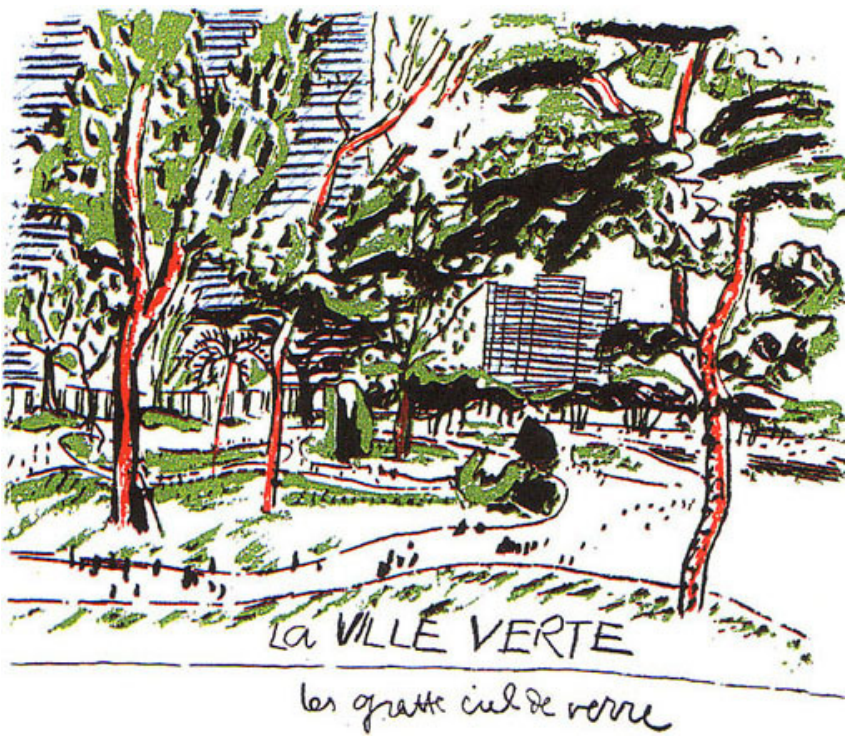

Fig.4 0 novo urbanismo proposto por Le Corbusier. Os edifícios aparecem entre a vegetação intensa.
Na visão de Solá-Moralles este fato introduz um novo conceito de cidade, a cidade que se faz paisagem em seu exterior, "esto es, un nuevo genero artístico que no es exactamente ni arquitectura ni pintura, sino, únicamente, una construcción figurativa, evocadora de las ideas modernas de libertad e higiene, es decir, de independencia pública y privada del cuerpo (...)"42. Este meio onde o indivíduo se encontra não possui uma visão perspéctica e nem segue a ordenação arquitetônica clássica. Assim como um jardim pitoresco, a arquitetura e os monumentos são apenas acidentes. A busca da unidade na cidade moderna tem como resultado a "dispersão do espaço público". Enquanto as cidades antigas conseguem estabelecer um sistema analógico entre as escalas do desenho urbano, a lógica figurada por Le Corbusier não resulta num sistema comum ou homogêneo.

A concepção adotada tem como desdobramento a desconexão entre arquitetura e urbanismo, ou melhor, a dispersão formal. Da mesma maneira a cidade aparece nos espaços públicos como mera paisagem e também não define o que o homem tem a fazer: "ni la visión perspectiva clásica ni la ordenación que la arquitectura podía introducir en la ciudad clásica."43

A proposta regular-centro/pitoresco-periferia inverte totalmente a proposta giovannoniana. Esta inversão pressupõe a destruição do existente para a concepção do novo fundador, e mesmo assim, a ruptura desejada por Le Corbusier não define a unicidade na concepção espacial moderna desejada. Nem a destruição total do antigo confirma a nova unidade formal entre arquitetura e urbanismo.

O modelo universal modifica o sentido atribuído aos monumentos. Nos processos de construção da cidade tradicional a habitação é complementar ao

41 SOLÀ-MORALES, Ignasi. Le Corbusier. La dispersión del espacio público. In: Inscripciones..., op.cit, p.194.

42 Idem, p.195.

43 Idem, ibidem. 
monumento, ou seja, a série desta "arquitetura menor" em harmonia enobrece 0 valor simbólico do monumento e consequentemente da leitura do conjunto. Não é o que acontece aqui: na cidade funcional a habitação ganha o mesmo status do monumento, sendo passível também da infinita repetição pelo espaço indiferenciado. Nesta visão, as relações de significado cultural e simbólico são dificilmente criadas ${ }^{44}$.

As discussões da geração de Lina são em grande parte a intenção desesperada de reviver e reconhecer as perdas que a cidade moderna enfrenta. Dentro da dimensão coletiva buscada e das preocupações além funcionais da arquitetura moderna, os arquitetos do pós-guerra retomam questões já enunciadas no início do século XIX por caracterizar-se, este período, como um momento de grandes transformações nas cidades - não apenas por mudanças estruturais na sociedade, mas também pelo número significativo das destruições provenientes dos bombardeios. Algumas obras são retomadas como parte de um aprofundamento da complexa transformação do comportamento humano e seus reflexos na cidade. 0 tema das grandes cidades é então revisto por arquitetos e urbanistas devido ao impacto estabelecido pelas grandes guerras mundiais e o dever da reconstrução $0^{45}$.

O VIII CIAM ocorrido em 1951, em Hoddesdon, na Inglaterra, é um momento significativo de avaliação das intervenções nas cidades, onde se pode notar a apreensão sobre a pertinência do tema da relação entre 0 antigo e 0 novo. ${ }^{46}$ As discussões ocorridas neste Congresso importam para 0 desenvolvimento deste trabalho uma vez que o tema Coração da cidade

\footnotetext{
44 HUET, B. apud BARONE, Ana Claudia Castilho. Team 10: arquitetura como crítica. São Paulo: Annablume; Fapesp, 2002, p.46-47.

${ }^{45}$ Massimo Cacciari introduz a discussão da Metrópole e suas conseqüências através da retomada de dois autores que ele mesmo classifica como representantes da "vanguarda da crise": Georg Simmel e Walter Benjamin. Tanto para Simmel quanto para Benjamin a vida metropolitana consolida um processo de Espiritualização como abstração do pessoal e sua consolidação sobre a subjetividade, ou seja, como expressão mais desenvolvida da razão. No entanto, enquanto Simmel concebe uma visão otimista do processo de interiorização da economia monetária, Benjamin interpreta este fato como um momento ulterior ao domínio do capital, como estrutura da sociedade retirada das relações de produção que se contrapõe aos valores humanos e que conduz o homem à passividade. CACCIARI, Massimo. Dialética de lo negativo en la época de la metrópoli. In TAFFURI, CACCIARI, DAL CO. De la vanguardia a la metrópoli. Barcelona: Gustavo Gilli, 1972, p.15-151. Sobre os outros autores: BENJAMIN, Walter. Charles Baudelaire um lírico no auge do capitalismo. São Paulo: Brasiliense, 2000, p.114-115. SIMMEL, Georg. A metrópole e a vida mental. In: VELHO, Otávio Guilherme (org.) O fenômeno urbano. Rio de Janeiro: Zahar Editores, 1967.

${ }^{46}$ Destaca-se a publicação resultante do VIII CIAM: ROGERS, E. N., SERT,J.L., TYRWHITT. J. EI Corazón..., op.cit.
} 
proposto como questão circunscreve os objetos empíricos indicados na pesquisa e toda a problemática que eles suscitam ${ }^{47}$. Segundo Otilia Arantes, o lugar público torna-se base de estudo dos arquitetos dessa geração. A autora mostra a reação dos profissionais no sentido de tentar "devolver a cidade moderna à coletividade expropriada ao longo do processo de constituição das grandes aglomerações urbanas contemporâneas"48.

O principal mote presente em praticamente toda a discussão do VIII CIAM é o Coração da cidade, visto como lugar que oferece possibilidade de manifestação da vida social, seja ela transitória ou permanente. Para despertar esta necessidade no "homem passivo" é unânime a opinião que preza pela urgência de se criar lugares adequados, abertos e livres do tráfego na cidade: um Coração.

Apesar das críticas aos conceitos aludidos no VIII CIAM ${ }^{49}$, é importante tomá-los com certo distanciamento temporal e revê-los como experiência elucidativa de alguns assuntos colocados naquele momento. A grande pergunta formulada por Siegfried Giedion parece ser um início de investigação: “¿és realmente posible volver a crear hoy la sociabilidad, vieja como la humanidad, que há sido siempre considerada como una de las funciones de la ciudad?"50 Sob o pretexto da 'continuidade', da busca da sociabilidade, é que se preconizam questões sobre o espaço público e o respeito para com a cidade existente ou mesmo a própria valorização do monumento histórico como aglutinador de experiências comuns.

O texto produzido por Richards, "Elementos viejos y nuevos en el Corazón de la ciudad", enfrenta esta preocupação. ${ }^{51}$ Para ele, cada cidade carrega signos distintos de sua própria origem. O Coração, lugar onde reside

\footnotetext{
47 Os objetos empíricos a serem analisados são locais considerados espaços públicos importantes, marcos enquanto valor simbólico assumido na cidade, tanto o Centro histórico de Salvador como 0 Anhangabaú, em São Paulo.

${ }^{48}$ A autora faz uma espécie de "roteiro" de alguns autores que são importantes na discussão da arquitetura e urbanismo do pós-guerra. ARANTES, Otília. A ideologia..., op.cit.

49 Para Ignasi Solà-Morales, o próprio conceito do termo inglês core é ambíguo e esta é uma das razões do seu empate. A ambigüidade apareceria entre a sua forma como problema de desenho do espaço público e sua função, ou seja, a necessidade de uma nova função urbana, de centralidade multifuncional. Desta maneira, todas as intenções são voltadas para recuperar a unidade perdida da cidade clássica em meio à nova situação moderna, onde já não se reconhece sua função de centralidade formalizada e nem os elementos compositivos para a sua concepção. SOLÀ-MORALES, Ignasi. Op.cit.. Ver também ARANTES, Otilia. Op.cit.

50 GIEDION, Siegfried. El Corazón..., op.cit, p.160.

51 RICHARDS, J.M. "Elementos viejos y nuevos en el Corazón de la ciudad". In: ROGERS, E. N; SERT,J.L., TYRWHITT. J. El Corazón..., op. cit., p.60.
} 
esta característica de distinção entre cidades, seria capaz de fixar sua natureza na memória do habitante. Esta reverência à edilícia antiga é um modo de manter a continuidade da experiência humana ou de tutelar a possibilidade de conhecimento desse passado comum. É relevante a maneira como Richards trata o tema da memória, posto que a entende desde o presente e segue a sua perspectiva projetual respeitando a continuidade dessa experiência humana. 0 interesse pelo antigo vem da apreciação da atmosfera criada pelo passado, explicado como forma de compreensão psicológica e do conhecimento visual dos objetos físicos - o edificado, ou mesmo, os espaços livres. Neste ponto, é visível a referência aos autores tratados anteriormente em relação à questão do patrimônio urbano histórico. Este caráter observado sobre a real representatividade do antigo e sua forma preexistente é uma das matériasprimas com a qual 0 arquiteto trabalha para a sua criação da mesma forma que considera as características topográficas ou climáticas do local, o que podemos chamar de preexistência. Nota-se, sobretudo, a visão do passado através de uma continuidade e não de ruptura. Desta forma, a inserção do novo na preexistência é algo desejado e necessário. Sobre esta atuação põe em evidência:

"[...] para obtener esta armonía no deben construirse edificios nuevos en estilos antiguos, ni seguirse otras practicas análogas. Los centros de la ciudad que construimos son la expresión de nuestra cultura: son lo que nuestra fantasía puede crea valiéndose de los recursos puestos a nuestra disposición por la ciencia e deben llevar, en todos sus aspectos, el sello de nuestro tiempo."52

O Coração, assim como a cidade, desde sempre mantém a característica de mutação, no entanto, esta modificação espontânea possibilita constantemente uma harmonia entre a convivência das diversas estratificações temporais. A permanência desta propriedade é o que o autor busca. 0 antigo e 0 novo rompem as oposições e convivem entre si construindo suas especificidades, a 'personalidade' de cada lugar. 0 predicado particular é o que promove a identificação citadina e a preocupação com a continuidade deste atributo evidencia uma postura reacionária frente às tendências de estandartização dos elementos construtivos e a repetição das soluções urbanas iguais, regulares e universais. Assim, a grande dificuldade do urbanista é

\footnotetext{
52 Idem, ibidem.
} 
determinar até que ponto a mudança deve estar sujeita ao seu controle, e ainda, como garantir que a particularidade da cidade seja conservada ou mesmo transformada para que continue vital. $O$ interesse pelo preexistente vem da apreciação da ambiência criada e pelo conhecimento visual dos objetos físicos herdados do passado. Essa matéria 'existente' é tão importante para 0 desdobramento do projeto quanto a natureza do terreno ou a qualidade da luz solar.

Tornam-se proeminentes aqui as aproximações entre as questões de cunho urbano consideradas naquele momento e as demandas levantadas pela Teoria da Restauração através da chancela da preexistência. A preocupação com a preexistência somente acontece a partir de determinantes entre mudanças e permanências e esta oscilação entre antigo/novo é uma componente característica da prática do restauro. ${ }^{53}$ Conforme indica Enzo Paci, o coração da cidade enquanto momento dialético do movimento centrípeto e centrífugo é também a síntese entre 0 velho e o novo, entre permanência e emergência, ou seja, cenário de um drama que freqüentemente se renova. ${ }^{54} \hat{E}$ relevante constatar que a preexistência não é apenas uma questão morfológica, resultante da forma, mas também é direcionada pelas discussões sobre os problemas sociais, o que evidencia verdadeiros momentos de estreitamento entre o projeto arquitetônico e o plano urbanístico. Dessa maneira, a preexistência também está ligada à questão do uso cotidiano presente e, portanto, "I'equilibrio estético, l'armonia è una sintese dinamica tra una possibilità nuova e il condizionamento della tradizione di cui il valore è riconosciuto próprio in quanto la nuova funzionalità non si pone como astratta ma come effettivo rinnovamento in una continuità". 55

É importante considerar um precedente teórico do VIII CIAM. Giedion, ao tratar das transformações estruturais das cidades do século XX, faz a relação entre comportamento humano e produção de lugares. Num primeiro momento, considera extremamente importante a ruptura ocorrida na cidade industrial entre o pensamento e a estrutura da sensibilidade, tendo como conseqüência o hiato entre criadores da arte e o público. Para 0 autor, estabelece-se um abissal

${ }^{53}$ Cf. CARBONARA, Giovanni. Architettura e restauro oggi a confronto. Palladio, n.35, 2005, p.114.

${ }^{54} \mathrm{PACl}$, Enzo. II cuore della città. In: Casabella Continuità, n.202, ago-set, 1954, p.IX.

55 Idem. 
rompimento entre arquitetura e comunidade ${ }^{56}$. A afirmação e a consolidação desta ruptura estão presentes na produção arquitetônica ligada ao gosto comum da época, o que banaliza explicitamente os valores simbólicos dos monumentos através de uma mera escolha individual de um repertório superficial e puramente formal da arquitetura. Esta obra, na verdade, retoma o início deste estudo sobre a procura do diálogo entre profissionais e público através da formação da nova sensibilidade.

Os pontos principais colocados como solução ideal para restabelecer a continuidade na arquitetura e seu verdadeiro valor recaem sobre o monumento e seu valor simbólico. Isto fica evidente no manifesto escrito em 1943 por Giedion, o pintor Fernand Léger e o arquiteto e urbanista José Luis Sert. Neste manifesto, os autores colocam a premência de retomar a importância da monumentalidade como estrito valor coletivo e como fundamental necessidade humana. Os escritos deste manifesto que pontuam a necessidade humana do monumento são claramente retomados mais tarde no CIAM.

"[...] De los edifícios destinados a su sensibilidad social y a su vida comunal, el pueblo anhela algo más que una mera satisfacción funcional. Desea que en ellos se tenga en cuenta su ansia de monumentalidad, de alegria y íntima exaltación.

Cumpliendo con estas condiciones, la arquitectura monumental cumpliria otra vez con su primer objetivo y recobraría su contenido lirico." .(grifo do autor) ${ }^{57}$

Frente às conseqüências da sociedade individualista, dispersa e anônima, resultado de um modelo baseado na produção somado às conseqüências da Segunda Guerra Mundial, os intelectuais exigem o compromisso de tentar reconstruir as cidades levando os benefícios da arte e da técnica em prol da construção física de um espaço em que se desenvolva a vida social. Em outras palavras, devolver a cidade moderna à coletividade. Essa intenção produz o que Otília Arantes chama de uma verdadeira obsessão pelo lugar público como remédio mais indicado para a patologia da cidade funcional. 58

Giedion, ao resumir as propostas do CIAM, fala da evidente desconfiança que aquela geração nutria pela gradual mecanização, seus

${ }^{56}$ Título do livro que desenvolve o tema. GIEDION, S. Arquitectura y Comunidad. Buenos Aires: Ediciones Nueva Vision, 1963.

${ }^{57}$ Os nove pontos sobre a monumentalidade. Idem, p. 45 .

${ }^{58}$ ARANTES, Otília. Op.cit., p. 97. A substituição da palavra espaço por lugar na sentença "lugar público" é compreendida aqui como interiorização do conceito de lugar empregado por Aldo Rossi, ou seja, o espaço qualificado por sua unicidade, carregado de sentidos históricos ou mesmo psicológicos. Significação em grande parte feita pela coletividade. 
pressupostos e a conseqüente necessidade em despertar o respeito para com a vida humana. ${ }^{59}$ Os problemas perpassam a necessidade de restabelecer a relação entre o indivíduo e a comunidade - valores buscados nas antigas cidades e na relação estabelecida na arquitetura entre 0 antigo/novo. A união entre estas duas esferas é literalmente colocada sob a responsabilidade urbana, em especial sob a parte central da cidade: 0 Coração da Cidade. 0 desafio de criar estes espaços devidamente freqüentados de maneira desejada solicita de imediato a união de vários especialistas além de arquitetos e urbanistas. 0 Coração não é somente um centro físico de uma aglomeração, mas um local de reunião da comunidade, de identificação coletiva: um lugar.

Todavia, o surgimento do problema do Coração como tema não é outra coisa que tentar reaver algo já desaparecido (o centro único utilizado como encontro social, político ou administrativo) e evidenciado tanto na proposta de Le Corbusier como na proposta de fragmentação de Giovannoni. Mesmo assim, contra a tendência da dispersão, desenvolvem-se diversas vertentes de reflexão neste CIAM e é esta reação dos arquitetos e urbanistas sobre as propostas modernas vanguardistas que o tema antigo/novo é retomado nas pautas dos arquitetos e urbanistas; na figura do Coração da cidade a relação entre permanência e inovação se estabelece com maior intensidade.

Apesar das iniciativas de recomposição do lugar público e da idéia subjacente de reconsiderar a continuidade perdida na cidade moderna, os projetos apresentados durante 0 VIII CIAM ainda mantêm a velha sensação de objetos isolados sobre a superficie plana do cuore.

As advertências e preocupações configuradas no balanço dos últimos Congressos mostram exatamente em que medida cada cultura projetual vive a relação entre antigo/novo, "serrata dialettica tra continuità e discontinuità, tra permanenze e mutamenti, tra ricorrenze e casualità. Una cultura progettuale è quindi tanto più valida quanto più riesce a vivere in una condizione di orgânica alternanza tra permanenze e mutamenti [...]."60

${ }^{59}$ GIEDION, Siegfried. El corazón...,op.cit. Sobre o assunto também se destaca BARONE, Ana Claudia Castilho. Op.cit.

60 PURINI, Franco. Permanenze e mutamenti nell'archittetura italiana. Universitá degli Studi di Roma 'La Sapienza', Facoltà di Architteutra 'Valle Giulia', Roma, 2004. Apud CARBONARA, Giovanni. Architettura..., op.cit. 
A crítica e a nova tomada de rumos na arquitetura e no urbanismo ganham corpo após o VIII CIAM. O décimo encontro, conhecido por Team 10, marca a asserção da discussão urbana sobre as relações sociais na cidade, o que perpetua até 1984 .

"A intenção fundamental dos jovens era questionar a validade desses princípios universais a partir da noção de que o homem se organiza em comunidades, que desenvolve a necessidade de se diferenciar, se identificar com o local onde habita, criar vínculos sociais e apreender o espaço a partir de seus próprios valores culturais." 61

A postura então adotada condiz com a necessidade interdisciplinar de enfrentar um objeto complexo e plural como a cidade. A garantia de respeito para com as particularidades das propostas de cada membro em contraponto ao apelo universal e apolítico permite esta abrangência. Isso não significa em nenhum momento abdicar às conquistas modernas, mas sim reavaliá-las através das relações com a cidade existente, com as condições naturais do lugar ou trabalhar com as categorias culturais particulares. Evidentemente, esta fala não é homogênea e se divide em alguns grupos conforme as linhas de interpretação. A discussão enfrentada aponta para uma busca constante da maneira de se expressar a vital relação entre homem e lugar62. É aqui que se torna importante a noção de identidade: "A cidade seria a ultima instância de identidade coletiva, uma associação de diversas comunidades"63

Destaca-se aqui a posição da vertente que considera a valorização do contexto defendida inicialmente por Ernesto Nathan Rogers, pois abre precedente para as discussões posteriores sobre contexto da formação de Lina. Este assunto será tratado mais adiante.

museu, arquitetura e cidade: antigo e novo como questão Nas pesquisas feitas e orientadas pelo professor Renato Anelli é plausivel reconhecer que o tema da relação entre 0 antigo e o novo é freqüentemente trabalhado na Itália no desenvolvimento das formas expositivas

61 BARONE, Ana Claudia Castilho. Op. cit. p.61.

${ }^{62}$ ARANTES, Otília. Op.cit., p. 97.

${ }^{63}$ BARONE, Ana Claudia Castilho. Op.cit. p.80. 
no entre-guerras ${ }^{64}$. A compreensão deste fato permite antever um primeiro momento de referência concreta ao tema da relação entre o antigo e o novo e de experimentação direta da sensibilidade moderna na Itália. Evidentemente esta experiência das formas expositivas proporciona a aproximação entre 0 debate das vanguardas modernas e a sensibilidade dos italianos na década de 1930.

Segundo Anelli, algumas formas de expor de outros países são absorvidas rapidamente na Itália ${ }^{65}$. Esta inusitada experiência de percepção visual é traduzida como um momento de educação do público para a nova sensibilidade ${ }^{66}$. É preponderante, se pensarmos na Itália, a tensão entre 0 antigo e o novo por se tratar de exposições afinadas com as propostas abstratas de vanguarda européia postas em ambientes vetustos. É compreensível que a Itália, com o peso ingente da tradição, seja o foco das discussões sobre este convívio.

Neste momento apontado por Anelli pode-se dizer que o convívio dos tempos é despertado pela simultaneidade, pela coexistência de diferentes tempos e linguagens. Em resumo, a experiência expositiva cria uma tensão entre figuratividade e temporalidade que contribui para construir um novo olhar moderno, pois privilegia a percepção e a experiência espacial do visitante. A sensibilidade do espaço moderno é arrostada através do desing (dos desenhos dos suportes até a maneira de se expor as obras) tendo como matriz a experiência abstrata alemã. Edoardo Persico é o porta-voz desta experiência. A obra não se encontra mais em locais herméticos ou em ambientes neutros, mas são colocadas diretamente nestes ambientes antigos: o resultado visual é incisivamente gráfico, semelhante a uma "colagem". Essa ação expositiva, inicialmente entendida como ação pedagógica através da simultaneidade dos

${ }^{64}$ ANELLI, Renato Luiz Sobral. Op.cit, p.50-60. Destaca-se também: PEREIRA, Juliano A. A ação cultural de Lina Bo Bardi na Bahia e no Nordeste (1958-1964). Dissertação de Mestrado. USP- São Carlos, 2001, p.111.

${ }^{65} \mathrm{Cf}$. Anelli "Por ter se constituído em um dos poucos espaços de atuação ocupado pela primeira geração racionalista entre 1928 e 1932, quando então se abre um amplo campo de trabalho mediado por uma política conciliatória, a trajetória das exposições se confunde com a própria história da aproximação dos italianos com a arquitetura das vanguardas modernas.[...] A construção de espaços onde essa nova arquitetura fosse experimentada, mesmo que através da cenografia de teatro e de cinema, constituiria instrumento eficiente para sua propagação, uma vez que apresentaria para as pessoas o que corresponde, na arquitetura, ao estilo moderno que elas já vivenciam. Assim, a modernidade não necessitaria ser imposta pelo Estado. Amplamente difundida, a sociedade passaria a aspirar por ela". ANELLI, Renato Luiz Sobral. Op. cit., pp.50-51. 66 Conforme observa Anelli, este momento é um contraponto à estratégia iniciada por Pietro Maria Bardi e o grupo MIAR (Movimento Italiano para a Arquitetura Racional), que defendem esta modificação da sensibilidade através do Estado. Idem, p.50. 

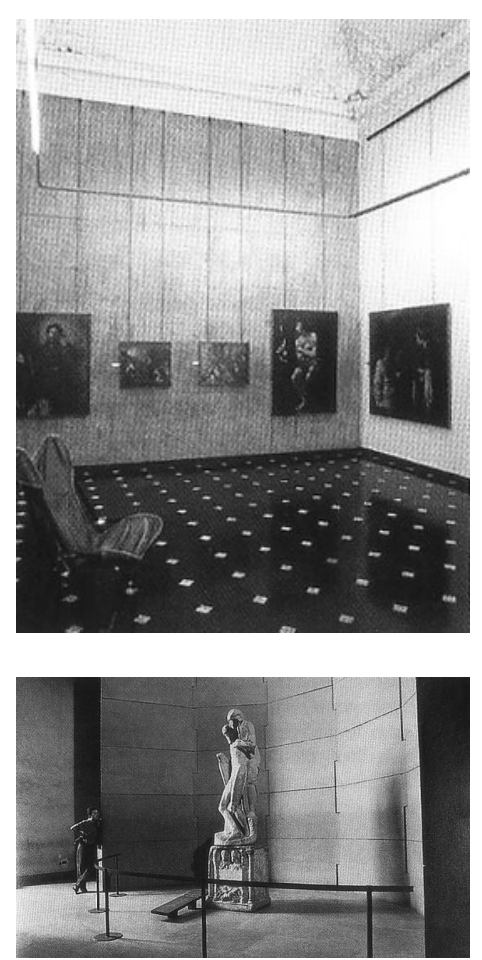

Fig.5 Palazzo Rosso, Genova. Franco Albibi (1950).

Fig. 6 Castello Sforzesco, Sala Scarlioni, Milão. BBPR, grupo composto por Gianluigi Banfi, Lodovico Belgiojoso, Enrico Peressutti e Ernesto Nathan Rogers (1956). tempos, funciona como laboratório da percepção e diálogo entre intelectuais e massa, desdobrando-se mais adiante em outros campos de atuação. A experiência expositiva tem um desenvolvimento que se origina das propagandas ou vitrines, passa por exposições e chega até a museologia ${ }^{67}$.

O momento de discussão das formas expositivas do entre-guerras com o objetivo de se criar uma nova percepção funciona como uma experimentação apropriada ao debate sobre a memória no pós-guerra, e, evidentemente, trata-se de uma ocasião de revisão das categorias culturais envolvidas - principalmente da noção de passado, história, memória, lugar, etc. Portanto, o devir das discussões sobre a relação entre 0 antigo e o novo se sobrepõe ao debate das intervenções em preexistências. Isto quer dizer a consideração das técnicas de restauro tanto nas ações museológicas quanto no aproveitamento dos antigos edifícios e lugares ("centros históricos").

Outras idéias são incorporadas nos períodos seguintes, resolvendo-se de forma diversa o sentido de tal simultaneidade espaço-temporal. Para Guglielmo Pacchioni as obras de arte (modernas ou antigas), além de terem uma visão simultânea, são transportadas para o mesmo plano de atualidade. A produção artística se faz a partir de uma experiência presente que envolve principalmente a percepção dos visitantes ao mesmo tempo em que os lugares são re-elaborados com usos contemporâneos. A inserção do passado num plano presente contribui para a apreensão crítica de qualquer tipo de pessoa. "Expor uma obra de arte significa dar um valor que leve 'seja antiga ou moderna, para um plano de atualidade' tornando-a facilmente acessivel ao maior número de observadores."68

Solà-Moralles, ao discorrer sobre o método riegeliano, elabora uma metáfora com o museu que pode contribuir com a discussão aqui proposta. Conforme 0 autor, as proposições elaboradas por Alois Riegl, como teórico e historiador da arte, decorrem de sua própria experiência em museus. ${ }^{69}$ "Era necesario pensar el museo - pensar la história y la interpretación del arte - de

\footnotetext{
${ }^{67}$ Idem, p.51.

68 Idem, p.55.

69 "[...] su pensamiento nace como un esfuerzo por repensar el sentido y la significación de la obra de arte cuando el esquema ilustrado del museo como colección ha entrado en crisis y, por tanto, también la História del Arte como mera clasificación." SOLÀ-MORALES, Ignasi. Para un museo moderno: de Riegl a Giedion, In: Inscripciones, op.cit, p.131-141. Nota o autor que Riegl foi conservador no Museu de Artes decorativas em Viena de 1883 até 1897, período de intensa publicação sobre o tema.
} 


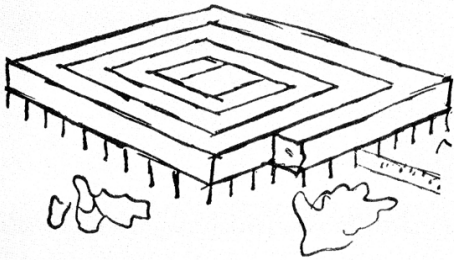

Fig.7 Le Corbusier. Museu de crescimento ilimitado (1939). otra manera, por otras vias y a partir de hipótesis distintas. Era necesario rechazar los compartimientos estancos de los estilos y de la diversidad de disciplinas artísticas."70 A experiência do exame crítico na produção artística provoca a necessidade de um outro método (que não o normativo). A conservação dos monumentos é abordada até então sob a "perspectiva profissional", dada apenas pelos debates entre doutrinas, evidente nas posturas opostas: a ação intervencionista de Viollet-le-Duc e a ação conservadora de Ruskin ${ }^{71}$. No entanto, a tese do historiador de arte vienense Riegl sobre a noção de "valor artístico" aplicada ao monumento vem modificar esta postura especializada, num momento de extrema consciência do problema enquanto objeto social e filosófico. ${ }^{72}$

O principal motivo de confronto entre a motivação renovadora e a permanência do monumento é exatamente uma questão metodológica que implica na relatividade do "valor artístico", conforme Riegl, na medida em que satisfaz o Kunstwollen ${ }^{73}$ de cada época. A relativização dos valores conferidos aos monumentos, que caracteriza a maneira de se relacionar com os objetos herdados em cada época, é o fundamental ponto de partida para entender as especificidades de cada momento assim como os confrontos pragmáticos. Estabelece-se uma discussão entre os objetos perenes versus os valores relativos exatamente por considerar a prática conservativa um produto casuístico e não normativo. Isto tem grande importância, uma vez que Riegl encontra-se sob a responsabilidade de dar respostas para estas ações conservativas no começo do século XX. Apesar de Riegl acreditar que o "valor de antiguidade" prevaleceria sobre o "valor histórico" na sociedade de massa - por tratar-se de um valor facilmente apontado pelo aspecto antigo ou mesmo pelo simples contraste evidente entre antigo/novo -, o que predomina, entretanto, é a linha

\footnotetext{
70 Idem, p.132.

71 RUSKIN, John. Las siete..., op.cit; VIOLLET-LE-DUC, Eugène Emmanuel. Restauração. São Paulo: Ateliê Editorial, 2000. Vale destacar que, na mesma ocasião que Riegl escreve o Culto moderno aos Monumentos, Camillo Boito confronta as duas posturas antagônicas de Ruskin e Viollet-le-Duc e faz uma espécie de síntese, numa via conhecida como 'restauro filológico'. BOITO, Camilo. Os Restauradores. São Paulo: Ateliê Editorial, 2002.

72 RIEGL, Aloïs. Le culte..., op.cit. Não podemos esquecer que esta obra não pode ser lida de modo restrito, mas deve ser vista como princípio teórico básico para a sistematização da regulamentação e das ações de ordem prática na conservação dos monumentos austríacos. Foi escrita em 1903.

73 Para Riegl o valor é ligado ao conceito de Kunstwollen, ou seja, uma espécie de desejo artístico predominante em cada época, que passa de sociedade para sociedade, e ainda, de indivíduo para
} indivíduo. 
que segue em direção à possibilidade de estacionar o processo de degradação natural da obra. $\mathrm{O}$ que significa dizer que mais uma vez intelectuais e massa acabam em direções opostas. Segundo Riegl, do culto ao "valor de antiguidade" poderia emergir uma ação conservativa no sentido de deixar visível a vida do documento histórico, provocar a sensação do tempo transcorrido através das marcas deixadas na passagem do tempo e do homem. Respeitar-se-ia, portanto, as fases de intervenção humana, das "práticas sociais" presentes nas identificáveis estratificações ${ }^{74}$.

Esta contribuição na discussão sobre o monumento ${ }^{75}$ e seu valor é 0 deslocamento do foco do objeto em si (e suas características estilísticas) para a percepção humana do objeto. Este fato revela uma mudança de metodologia que implica no conhecimento do funcionamento da percepção e dos princípios que norteiam a práxis. Essa experiência coloca o museu numa condição de instrumento de conhecimento e de produção feita desde a percepção do sujeito. Certamente, pressupõem-se outros fatores ligados a distintos campos que venham a constituir a qualidade da percepção. A condição social, histórica, psicológica, ou ainda, as condições materiais e culturais são fatores que relativizam a forma de leitura sobre os monumentos.

"El museo de Riegl, para seguir usando una vez más esta metáfora, no es un museo de arte separado de las otras ramas del saber y de la historia humana, sino que, como parte de la cultura, se propone como un despliegue de la conciencia histórica de los individuos o de las sociedades, en un tiempo y en un espacio preciso, y como expresión sensible de esta misma conciencia histórica"76

Ao que parece evidente, o museu adquire um efeito de troca entre arte e os pressupostos da cultura. $\mathrm{Na}$ verdade, adquirem um sentido de

\footnotetext{
74 Este caminho poderia dialogar com as discussões intelectuais, mas o que se estabelece é exatamente o contrário. Os casos do Pelourinho em Salvador, do Dragão do Mar em Fortaleza, do Bairro do Recife são exemplos. Muitos leigos consideram a intervenção "uma maravilha", pois acreditam que o passado é retomado exatamente como foi. As intervenções têm a aparência renovada, colorida e brilhante, no entanto, resolvem-se através de meras formas idealizadas e que não correspondem à realidade.

750 tema monumento e as diferentes abordagens aparecem constantemente na bibliografia. Além do conceito adotado aqui, advindo das indagações de Françoise Choay sobre a definição adotada por Riegl, destacam-se também: ROGERS, E. N. Experiência de la arquitectura. Buenos Aires: Ediciones Nueva Vision, 1965, p.37; ROSSI, Aldo. La Arquitectura de la Ciudad. Barcelona: Gustavo Gili, 1999; GIEDION, S. Arquitectura..., op.cit, p.29; LE GOFF, Jacques. "Memória". In: e Memória. Campinas: Editora Unicamp, 2003, p.535; SENNETT, Richard. O Declínio do Homem Público. São Paulo: Companhia das Letras, 1998, p.75. JEUDY, Henry- Pierre. Memória do social. Rio de Janeiro: Forense Universitária, 1990, p.10; FREIRE, Cristina. Além dos mapas: os monumentos no imaginário urbano contemporâneo. São Paulo: SESC; Annablume, 1997.

${ }^{76}$ SOLÀ-MORALES, Ignasi de. Para un..., op.cit, p.138.
} 


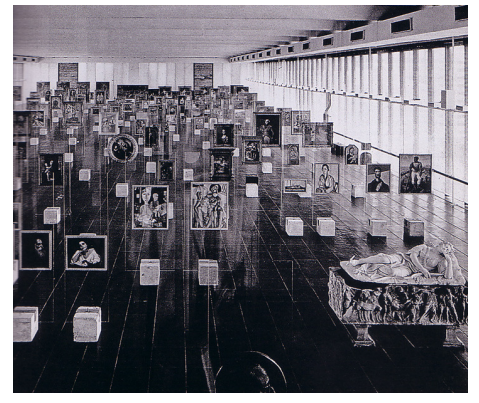

Fig.8 Pinacoteca do MASP, com as obras expostas em cavaletes de vidro. reciprocidade..$^{77}$ Este adendo sobre Riegl deve ser considerado através das condições de seu contexto. A noção de valor desenvolvida pelo vienense tem um objetivo prático, ou seja, aponta uma metodologia com fim na conservação de monumentos. 0 ponto de vista sobre a questão da percepção se aproxima com as questões suscitadas no desenvolvimento da prática expositiva italiana, uma vez que a abordagem da geração italiana do entre-guerras - e mesmo de Lina está pautada diretamente na formação da percepção e não apenas numa noção meramente conservativa do objeto a salvaguardar. Para que isso seja possível também é necessário reafirmar e concretizar o Kunstwollen da época, o que talvez explique a necessidade comunicativa dos arquitetos da geração de Lina.

A discussão das formas expositivas na Itália é retomada pela arquiteta e levada às ultimas conseqüências na proposição do Museu de Arte de São Paulo (MASP) em 1947. Diante de uma historiografia dos museus significante, a trajetória italiana esboçada - de cunho metodológico advindo inteiramente do design - reintroduz o museu como instrumento pedagógico para a nova sensibilidade moderna - e não como mero depósito de coisas antigas. Ou seja, traz para o momento presente a importância do exame crítico; torna viva a experiência passada.

Sob estes aspectos, o tema da convivência entre 0 antigo e o novo inicialmente provocada por ações pontuais expositivas pode ser tomado como um ponto importante da formação de Lina basicamente em duas frentes: primeiro, na ação pedagógica que pretende "atualizar" o passado através da própria percepção espontânea do visitante (erudito ou inculto) usando-se do método da simultaneidade do antigo e do novo, e do próprio contraste existente entre as estratificações temporais. Este método procura retirar o lado hierárquico e culto das obras pois não define por exemplo, um percurso cronológico ou mesmo uma organização feita a priori através dos "estilos", em suma, não prioriza apenas o público detentor de um conhecimento histórico e artístico, mas também aqueles que apenas percebem sinais simples, como o pueril contraste (e convívio) entre o antigo e o novo; segundo, na consideração da preexistência como dado importante durante o seu processo de criação.

77 Solà-Morales considera como emblemático desta questão o esquema apontado por Le Corbusier na idéia de museu. No entanto, a forma espiral esboçada apesar de ser ilimitada ainda contém uma hierarquia (início e fim). Idem, p.141. 
Não é mera coincidência que os estudos sobre Lina esbarrem sempre na experiência dos museus. Talvez seja porque é justamente nessa atividade que a arquiteta sintetiza de fato as noções que percorrem toda a sua obra. Porque a metáfora proposta por Manfredo Tafuri se efetiva78: é no museu que se tem a latente necessidade de confirmações dessas ações, pois são estas questões os meios de sua existência - o significado da memória, passado, história, cultura, etc. É no museu que se recupera o significado de modernidade da geração do pós-guerra e se tem efetivada uma metodologia coerente com 0 discurso desde a concepção expositiva até à implantação no terreno, passando, inclusive, pelo detalhamento do projeto. Pode-se apontar no museu um procedimento de síntese da revisão das categorias culturais.

A construção de uma percepção moderna é o que Lina - na concepção do MASP - leva ao extremo. A arquiteta entra em contato com outros exemplos

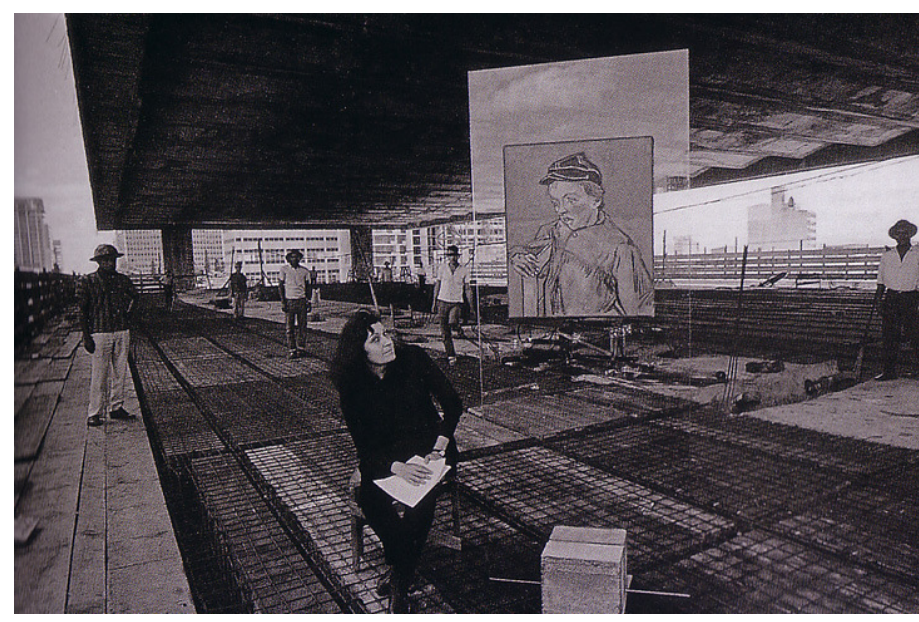
advindos da própria América que enfatizam a necessidade pedagógica e atual do museu. $A$ experiência americana propõe, desde a década de 1920 , essa nova sensibilidade moderna, ${ }^{79}$ de modo que Lina aponta os Estados Unidos como vanguarda da concepção moderna e do "desenvolvimento vivo de todas as iniciativas museológicas que tendem a fazer dos museus um instrumento de educação pública." ${ }^{\circ 0} \mathrm{~A}$ força educativa do museu, dentro do objetivo geral do

Fig.9 Lina, entre os obreiros, verificando o cavalete de vidro no próprio canteiro de obras do MASP.
78 Tafuri fala da relação com a preexistência a partir do paralelismo entre museu e cidade. In: TAFURI, Manfredo. Aufklärung II. II museo, la storia, la metáfora. In: Storia dell'architettura italiana 1944-1985. Torino: Giulio Einaudi Editore, 1982.

${ }^{79}$ Como bem lembra Silvana Rubino sobre o Museum of Modern Art de Nova York (MOMA), criado em 1929: "já não se tratava mais de um museu guardião do passado e, sim de um espaço fundador, instaurador e consagrador de experiências estético-culturais presentes - da modernidade e do saber vê-la e usa-la." RUBINO, Silvana Barbosa. Rotas..., op.cit., p.19. Sobre o assunto ver: ARGAN, Giulio Carlo. Arte Moderna. São Paulo: Companhia das Letras, 1992, pp.512-14.

80 BARDI, Lina Bo. Os museus vivos nos Estados Unidos. In Habitat, n.8, 1950, p.12. Também sobre 0 assunto destacam-se os textos da arquiteta para o Museu de Arte Moderna da Bahia. Enquanto Lina esteve presente no museu, acreditava-se que era típico de um país novo um museu moderno - não tem o significado conservativo ( no sentido de um acervo) mas sim o de criar um movimento cultural baseado numa experiência popular: "entrar no mundo da verdadeira cultura moderna, com os instrumentos da técnica, como método, e a força dum novo humanismo." Cinco anos entre os brancos: o Museu de Arte Moderna da Bahia. Revista Caramelo, São Paulo, n.4, 1998. Publicado originalmente na Revista Mirantes das Artes, n.6, novembro de 1967. 

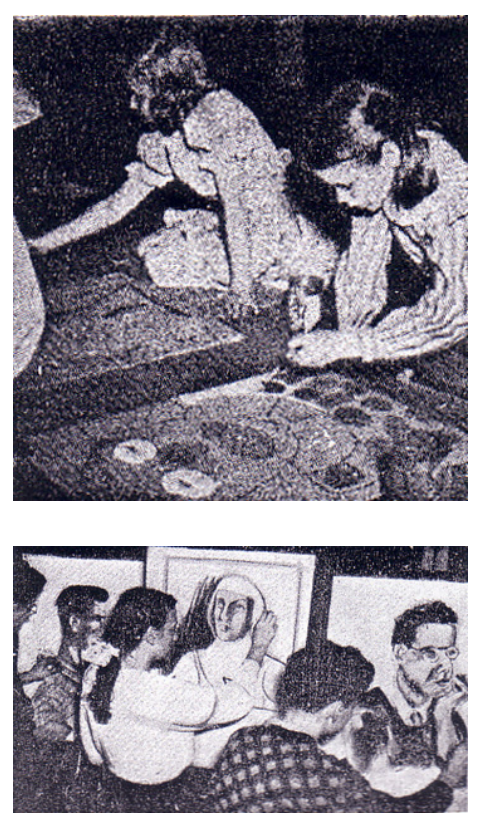

Fig.10 Fotos usadas por Lina no artigo sobre os museus americanos na Revista Habitat. Joslyn Art Museum.

Fig.11 Atividades pedagógicas do Museum of Art em Baltimore. impotente desenvolvimento cultural do país, vem somar-se à escola. Entende-se que ali seria possível "ministrar o sentimento das atividades criadoras e a consciência dos fatos históricos."11 Este museu americano não tem o caráter contemplativo ou turístico, mas possibilita a pesquisa e a contribuição didáticocomunicativa. É justamente a partir destas prerrogativas metodológicas que Lina concebe um projeto novo de museu para São Paulo ${ }^{82}$. Vários são os vestígios da nova concepção de museu: dos expositores de cristal (chamados de 'cavaletes') ${ }^{83}$ até 0 detalhamento da caixilharia. ${ }^{84} \mathrm{~A}$ fachada, por conseqüência, é a última forma de rompimento. A luz natural entra no ambiente expositivo e circula por entre as obras de arte e o público. Diferentemente do limite colocado para a geração italiana do entre-guerras na adaptação constante dos antigos espaços $^{85}$, Lina tem a chance de criar este lugar. Este projeto leva ao limite os anseios italianos: sem a intenção de ter um objetivo conservativo, a fachada de vidro possibilita colocar a coleção de arte no meio do cotidiano da cidade. Anelli reitera que

"Longe de serem um capricho formalista da autora, as fachadas de vidro do MASP expandem o espaço da Pinacoteca para a cidade. As transparências das fachadas e dos suportes estabelecem uma continuidade entre obra de arte e vida quotidiana, que enterra de vez qualquer pretensão aurática e, conforme palavras da autora, tira "do museu o ar de igreja que exclui os não iniciados". 86

\footnotetext{
81 Loc.cit.

82 Cf. Anelli "neste país de pouco passado e quase nenhuma consolidação cultural, em meio ao alvorecer de uma forte cultura moderna, a construção de um museu de arte envolvia o risco de fortalecer 0 apego conservador à herança artística européia. Um desafio que apenas poderia ser enfrentado por italianos com trajetórias como as suas, onde não se apresenta contradição entre 0 novo e antigo, o primeiro sendo uma decorrência do segundo, cada um fazendo seu sentido dentro do seu tempo histórico e ambos importantes para o presente." ANELLI, Renato Luiz Sobral. Op.cit., p.49.

83 Os cavaletes do MASP rompem definitivamente com a percepção visual segundo alguma ordem de subordinação e por isso a sua importância. Ver: RUBINO, Silvana Barbosa. Rotas...,op.cit., p.140; OLIVEIRA, Olívia F. Quarto de arquiteto: Lina Bo Bardi e a história. Revista Óculum: Campinas, n.5/6, p.83-88, mai- 1995; ANELLI, Renato Luiz Sobral. Op..cit, p.60.

84 Joaquim Guedes faz um texto elucidativo sobre 0 assunto. Ao trabalhar com a arquiteta, o que mais lhe chama a atenção é o desenho da caixilharia. "devo ter feito alusão ao fim do racionalismo, como era moda, ou ao neo-romantismo italiano de Zevi, Albini, Scarpa, Magitretti, Gio Colombo, Pomodoro, Sottsass, Farina, Mangiarotti,...querendo agradá-la. Lina ficou muito quieta e depois começou a falar baixo e lentamente, como se pensasse alto, flagrada e descoberta, uma frase inesquecível, que reproduzo de memória: 'acho que não. A sociedade brasileira necessidade de um desenho racional, claro e responsável. Penso que a burguesia européia entre guerras, não teve condições de lavar a poética do racionalismo às ultimas conseqüência's". GUEDES, Joaquim. Lembranças de Lina Bo Bradi. Revista Caramelo. São Paulo, n.4, 1992. Vale lembrar que dentro do MASP funciona o IAC (Instituto de Arte Contemporânea) que trada das questões pedagógicas ligadas ao design.

85 Dentre eles Franco Albini e Carlo Scarpa.

${ }^{86}$ ANELLI, Renato Luiz Sobral. Op. cit, p.60.
} 


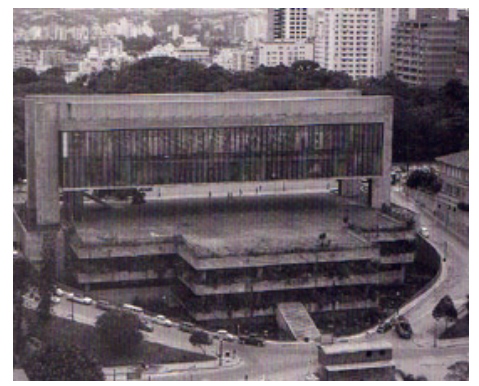

Fig.12 O MASP e o Belvedere.

A arquiteta afirma substancialmente a preexistência e 0 caráter particular do lugar: Belvedere, Avenida Paulista, São Paulo, Brasil, América. Além da fachada permeável visualmente, a implantação do MASP estabelece uma relação entre arquitetura e cidade que é fato de investigação. A decisão estrutural que parte de um "grande vão" também não é resultado de uma simples especulação de escolha estética, pelo contrário, surge como resposta ao limite imposto pelo terreno. A vocação do lugar é dada: pouso, contemplação, percepção da paisagem. Sob outra perspectiva, o MASP praticamente desalinha a Avenida Paulista ao avançar o recuo estabelecido pelo alinhamento das outras edificações. O MASP se impõe chamando atenção para o lugar em que acontece uma nova experiência cultural, como "definidor de um espaço urbano". 87

Uma outra leitura sobre a experiência museológica e a produção arquitetônica da geração dos arquitetos do segundo pós-guerra é a de Manfredo Tafuri, citado anteriormente. Este autor escreve um texto sobre o laboratório que a experiência museológica representa no enfrentamento da preexistência durante a mudança de escala (museu/cidade). Ou melhor, a questão sobre a relação entre o antigo e o novo apresenta a mesma problemática na arquitetura. Para 0 autor, a dificuldade apontada na experiência do museu e na arquitetura faz parte de um mesmo problema: a manipulação de um repertório através de um contato físico. O museu assume a forma de metáfora nas discussões sobre a memória e a inserção do novo nas cidades antigas. "L'Architettura del museo sembra riassumere, depuratti da molti scorie contingenti, i temi principali dibattuti negli anni cinquanta: dal ruolo 'civile' della forma a quello dell'incontro fra la memória e il nuovo, al recupero di una rappresentatività legata ad occasioni privilegiate"88 Um arquiteto analisado pelo autor e que corresponde a essa idéia presente na década de 1950 é Ernesto Nathan Rogers.

\footnotetext{
87 "As idéias urbanísticas que se impõem, após a Segunda Guerra Mundial, não são as de Gropius, e sim as de Wright, cuja arquitetura não é definida pelo tecido urbanístico, mas, pelo contrário, define-o. O Museu Guggenheim que Wright construiu no centro de Nova York, insere-se como um bloco plástico em espiral no alinhamento perspéctico de uma grande artéria e interrompe-0; 'local delegado' de uma experiência estético-cultural (museu de arte moderna), ele rompe a lei da uniformidade perspectiva da mesma forma como a igreja, na cidade antiga, isolava e definia o local da experiência religiosa." ARGAN, Giulio Carlo. Arte ..., op. cit., p.513.

88 TAFURI, Manfredo. Op.cit., p.64.
} 
Rogers comanda o movimento milanês Movimento Studi per Architettura (MAS) no pós-guerra89. A proposta de Rogers no fundo ambiciona corrigir a posição anti-histórica do movimento moderno através da leitura e permanência da vocação do lugar. Numa visão geral, é compreensível que a arquitetura italiana apresente a recíproca convivência entre 0 antigo e 0 novo como resposta nata, mais que qualquer outra nação, pois o problema é dado desde sempre. Um documento que pode ser objeto de destaque sobre estas questões é a Revista Casabella. Esta revista dá uma amostra imediata desse espírito no pós-guerra na Itália, da busca da arquitetura moderna fundamentada na tradição e na relação orgânica e humana presente na continuidade histórica de um povo.

Rogers dirige a revista a partir da década de 1950.90 A palavra Continuità impressa sobre o título da revista neste momento relembra o que se preconiza então: o empenho sobre a renovação da arquitetura somada à idéia de continuidade. Continuidade para o autor significa consciência histórica, verdadeira essência da tradição - aceitação direta da tendência que Pagano e Persico pressupõem como fator de modernidade. "Dinâmico proseguimento e non passiva ricopiatura: non maniera, non dogma, ma libera ricerca spregiudicata con costanza di metodo."91 Não é exatamente uma idolatria pelo passado, mas um exemplo a ser respeitado sem renunciar o espírito atual.

"Contro l'ímperialismo di ideologie imposte e malamente assorbite; contro il cosmopolitismo anódino delle recenti vernici accademiche, più nefaste delle vecchie muffe; contro lo sciovinismo dei nostalgici o dei rivoluzionari retrogradi: contro il folclorismo demaggogico. Siamo per um linguaggio veramente internazionale, ma fatto de mutua comprensione, dove ognuno possa contribuire con la sua liberta interiore culturale caratteristico della regione nella quale opera." 92

A problematização antigo/novo chega ao dilema da formação e da imposição da consciência histórica para guiar as intervenções. A racionalidade

${ }^{89} \mathrm{Na}$ pesquisa de Maria de Fátima Campello há indicações de que reuniões deste grupo acontecem no escritório de Lina em 1944.

${ }^{90}$ Neste período Lina está no Brasil atuando diretamente na Revista Habitat.

91 ROGERS, Ernesto N. Continuità. Casabella Continuità, n.199, dez. 1953- jan. 1954, pp. 1-3. Rogers segue o caminho da busca de Giuseppe Pagano pela arquitetura popular e espontânea como possibilidade de sintetizar a tradição popular e culta. Sobre o tema destacam-se ainda outros textos de Rogers como ___. Le responsabilità verso la tradizione. Casabella Continuittà, n.202, ago-set, 1954, pp.1-3; __ La tradizione dell'architettura moderna italiana. Casabella Continuittà, n.206, jul-ago, 1955, pp.1-7. Casabella Continuittà, n.294-295, dez-jan, 1964-65, pp.1-2.

92 Idem. 
deve manifestar-se na prática moderna, mas somente é reconhecida sua legitimidade caso seja estruturada por um juízo histórico-crítico de valor. Esta idéia culmina novamente no encontro da ótica da Teoria da Restauração do segundo pós-guerra com suas grandes transformações teóricas - o que é verificável na Carta de Veneza e a preocupação com a atividade da restauração como processo cultural, coletivo e fundamentado. ${ }^{93} \mathrm{~A}$ geração do pós-guerra tem 0 intuito de revelar o caráter complexo da cidade, não apenas sob os aspectos morfológicos, mas também sob as especificidades, a dimensão interna do cotidiano, o genius loci. A leitura do contexto é um tema que os arquitetos deste período percorrem. Os métodos são perseguidos de diferentes formas, mas envolvem, sobretudo, a qualificação do entendimento físico do lugar e a interação com a percepção de quem vive neste lugar. Nesta visão, a noção de "lugar", "vocação" e "habitar" entram em discussão sob influência dos pensamentos fenomenológicos de Norberg-Schulz e Heidegger ${ }^{94}$. É dessa forma que se colocam em pauta noções relativas à dimensão cultural existente no lugar - o que acaba confluindo para a conveniência de se investigar o campo da Teoria da Restauração, disciplina que, por excelência, enfrenta as questões sobre memória, história, monumento, identidade, lugar e, principalmente, as relações estabelecidas entre passado e presente. Pode-se afirmar que, nesse momento, há uma postura conciliatória entre os campos de atuação na cidade. A fim de devolver o valor imaterial simbólico e cultural da cidade, os arquitetos modernos da geração do pós-guerra manipulam noções como "monumentalidade", "lugar", "espontaneidade", "preexistência", "continuidade", através do escopo do lugar público: espaço que congrega a sociabilidade da comunidade, espaço de identificação e pertencimento. Estas noções são basicamente inerentes à prática de preservação e à investida sobre o tema da memória. O "confronto" entre arquitetura e restauro é posto então em condição eminente de construir a relação antigo/novo a partir das mesmas necessidades. No entanto, o ponto de partida da discussão se diferencia. Enquanto os arquitetos modernos do pós-guerra partem da premissa da renovação e construção do novo somada à conciliação das noções de continuidade e preocupação com o existente, a Teoria da

${ }^{93}$ Carta de Veneza. In: Cartas Patrimoniais. Rio de Janeiro: IPHAN, 2000, p.94.

94 Sobre o tema destaca-se a análise sobre o lugar como parte integrante da existência e não apenas uma mera localização. SCHULZ, Christian Norberg. Geniun Loce. Paesaggeo Ambiente Arquitetura. Milão: Electa, 1992. 
Restauração parte do inverso: a conservação e, consequentemente, 0 ato de restaurar - como ação empreendedora da característica cultural da obra - deve pressupor também soluções novas, relativas ao tempo que a cria, mas esta deve ser condicionada pela preexistência. Essa aproximação é possível basicamente porque a questão temporal e metodológica é revisada nos dois sentidos. Desse modo, pode-se afirmar que a relação entre 0 antigo e o novo consegue romper com a noção de opostos e contrários. Em ambos, a questão temporal é revisada e o passado é reiterado por sua característica interpretativa presente, relativa ao "presente histórico".

Sabe-se que as preocupações sobre a nova linguagem na arquitetura, sobre o senso crítico, a questão do método, a continuidade e a revisão temporal perpassam inúmeros grupos de discussão em distintas abordagens - 0 que resulta em diferentes atuações. Na atuação da arquiteta Lina, a resposta não ocupa uma postura unívoca, mas mantém 0 enfrentamento entre 0 antigo e 0 novo procedente dessa série de experiências. Dessa forma, é preciso ter cautela na análise de seus trabalhos e na aceitação direta de sua abordagem sobre 0 tema (desde entrevistas até os escritos publicados por ela). Suas intervenções em áreas de interesse patrimonial não acontecem por conciliação com Escolas ou vertentes da Teoria da Restauração, mas decorrem de uma postura crítica, fruto de sua formação européia, vale dizer, do peso propedêutico sobre bases filológicas, de seu envolvimento político e ético na profissão e de sua experiência proporcionada pelos anseios do design, principalmente no contato com o Brasil. A proposta de uma escola de design em Salvador e sua proposta pedagógica de usar a cultura popular como referência fundamental no desenvolvimento e produção do nordeste brasileiro segue a visão de inovar sem deixar de lado a continuidade da tradição local. É por este mesmo motivo que seu entendimento de museu assim como suas ações dentro do campo das intervenções urbanas não têm o significado de "guardar" ou "salvar" um acervo ou uma paisagem, mas sim o de criar um movimento cultural baseado numa experiência popular existente - no sentido de relação direta com as necessidades vivas e permanentes.

Não significa que Lina desconheça as modificações no campo da Teoria da Restauração nem que ignore as metodologias do campo. Constantemente, a arquiteta apropria-se das metodologias conforme as necessidades do momento. 

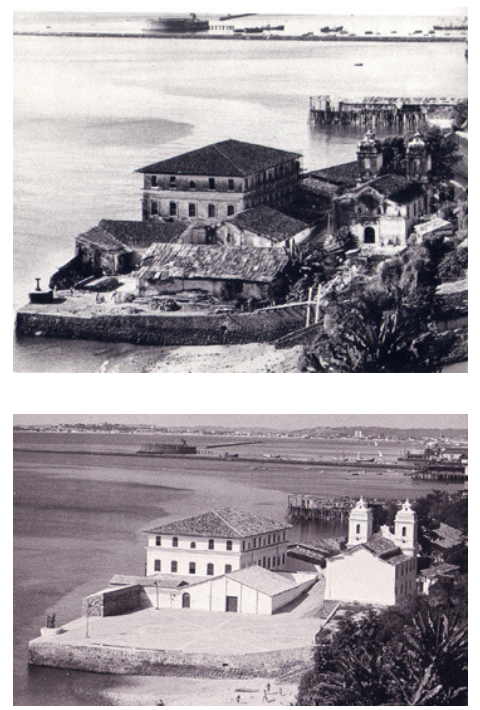

Fig.13 Conjunto arquitetônico do Unhão na década de 1970.

Fig.14 Conjunto arquitetônico do Unhão antes da restauração.
O exemplo da intervenção no Solar do Unhão em 1963, em Salvador, demonstra que Lina tem o conhecimento necessário para a tarefa de intervir sobre 0 patrimônio edificado. Antes mesmo da publicação da Carta de Veneza a arquiteta concede uma entrevista especificando exatamente seu conhecimento sobre o Restauro Crítico. O jornal local publica:

"o conjunto do Unhão foi restaurado de acordo com o método moderno da restauração crítica, cuja prática somente foi adotada depois da Segunda Guerra Mundial', segundo Lina Bo Bardi.

'O critério da restauracão crítica tem por base o respeito absoluto por tudo aquilo que o monumento representa como poética, dentro da interpretação moderna da continuidade histórica, procurando não embalsamar o monumento mas integrá-lo ao máximo na vida moderna' - explica Lina Bo Bardi ao repórter, falando de sua obra. 'Por isso é que não mudou nada, nem no Solar nem na Igreja'. Segundo ela, a Sra. Lina Bo Bardi o Unhão é um dos poucos exemplos da arquitetura histórica de um conjunto que não apresenta características dos monumentos antigos 'que põem 0 arquiteto frente 0 angustiante problema da escolha de uma época e do método de restauração (...).' O problema da superposição dos estilos, típico dos monumentos de uma determinada época, que sofreram transformações no variar dos tempos, todas elas importantes do ponto de vista arquitetônico mas que se excluem reciprocamente não existiu no caso do Unhão.

0 velho método romântico da recomposição inaugurado por Viollet-le-Duc foi superado depois de substituído pelo método da restauração cientíica, cujo principal representante foi o professor Giovannoni. Na Itália são ambos não somente superados mas inúteis neste momento de moderna restauração crítica, esclarece Lina Bo Bardi. O método crítico, de acordo com a Sra. Lina Bo Bardi mantém todo o conteúdo poético do monumento e procura integrá-lo na vida moderna, embora sem rejeitar soluções dos outros critérios de restauração quando indispensáveis mas sempre 'como fato de método, nunca como fim'." ${ }^{95}$ (grifo nosso)

A partir dessas afirmações verifica-se que Lina mantém-se atualizada em relação às novas proposições enfrentadas pela teoria do restauro arquitetônico, o que possivelmente deve-se à interlocução constante que a arquiteta mantém com seu amigo Bruno Zevi, historiador e crítico atuante no ambiente italiano, onde essas idéias vinham sendo elaboradas por teóricos como Renato Bonelli e Roberto Pane.

Um breve parêntese é sugerido no sentido de entender o que significa a interlocução com Zevi. Cabe destacar que esta leitura é proposta por este trabalho e que não é abertamente admitida por Lina; no entanto, não se pode negar que a partir de discussões constantes com o amigo muitas referências são apropriadas no discurso da arquiteta. Zevi, num artigo publicado no Brasil, na

95 SALVADOR. Museu salva a cultura da Bahia e o passado pela fé. Salvador, 21 de setembro de 1963 (artigo encontrado no arquivo do Solar do Unhão). 
Revista Caramelo, descreve exatamente os momentos de discussão com Lina.

"Discutimos e brigamos sobre cada questão, como autênticos amigos. Estávamos em desacordo sobre tudo, por exemplo: [...] sobre a identidade entre arquitetura e historiografia, ou seja, entre o ímpeto criativo e a moderna releitura do passado; sobre a exigência de uma linguagem codificada para a comunicação anticlássica e antiacadêmica; sobre a necessidade de condenar a simetria, o axial, as instalações prospectas, os volumes encaixotados, compactos e blocados, as estruturas tradicionais, as cavidades estáticas e inertes, a separação entre edifício, cidade e território; [...]."96

Merece destaque a posição de Zevi na discussão sobre o modo de ser moderno, e principalmente, em relação à inserção do novo em tecidos antigos, discussão interminável que acontece na Itália deste período, principalmente, nas vozes de Bruno Zevi, Cesare Brandi e Roberto Pane.

Em 1956, Cesare Brandi escreve sobre o tema da inserção do novo no antigo através da análise sobre a categoria espacial da cidade antiga e da cidade moderna. ${ }^{97} \mathrm{~A}$ invenção da perspectiva constituída por Brunelleschi apresenta para 0 autor o ponto inicial para entender a nova percepção do espaço instituído pelo Renascimento. Brandi explica claramente a técnica usada na pintura e na arquitetura que nos permite a afirmação sobre as mudanças de olhares características deste período, o qual suporta ainda a continuidade da antiguidade. A forma constituída na percepção do homem no Renascimento é preordenada por este artifício que permite criar um espaço novo: a perspectiva. A antiguidade, vista como modelo de perfeição, é reassumida e traduzida através da nova invenção de construção representativa do espaço e sua percepção. Não se produz, portanto, uma fratura entre 0 presente e o passado. Ou seja, 0 passado é revigorado e atualizado através de um princípio de linguagem, da técnica da perspectiva, e não da exterioridade da forma em si. "La definizione di questo ritmo nella prospecttiva fu certo creazione individuale de un gênio, ma fini per offrire la possibilità di una coesistenza del vecchio col nuovo, como non si era mai dato, come forse si dará più mai." 98

Brandi estuda a categoria da linguagem nos distintos períodos da arquitetura e conclui que existe sempre uma continuidade do antigo na re-

96 ZEVI, Bruno. Lina Bo Bardi: um architetto em tragito ansioso. Revista Caramelo. São Paulo, n.4, 1998.

${ }^{97}$ BRANDI, Cesari. Processo all'architettura moderna. L'Architettura, Cronache e Storia, n.II, 1956, pp. 356-60.

98 Idem, p.356. 
elaboração do novo. Para ele, mesmo o neoclássico não provoca uma ruptura, pois ainda possibilita a coexistência de monumentos de estilos diversos.

Igualmente, Brandi se depara com a questão moderna. A arquitetura moderna tem como principal característica a recusa da perspectiva e a conseqüente espacialidade proveniente deste meio. 0 volume isolado contradiz toda a experiência perspéctica do ponto focal, da continuidade e homogeneidade composta e desejada até então. Há, neste momento, um profundo rompimento na concepção espacial: a visão perspéctica anula a existência moderna, assim como a visão de espaço moderno contradiz a linguagem da perspectiva. Para Brandi não há como estabelecer qualquer tipo de coexistência entre 0 antigo e 0 moderno, pois, isto implicaria na autodestruição de ambos.

"[...] la architettura moderna, próprio in quanto ha il diritto di chiamarsi tale, non può essere inserita in un antico complesso urbano, senza distruggerlo e senza autodistruggersi: porchè un'opera d'arte si distrugge ove venga ad accettare delle condizioni spaziali che la negano, e altrettanto distrugge inragione di quelllo che negando afferma." 99

Como resposta à incompatibilidade antigo/novo prevista por Brandi, no mesmo ano Bruno Zevi se manifesta. Contrariamente à leitura espacial adotada por Brandi, Zevi relativiza os modelos estabelecidos. A visão perspéctica não significa a segurança de que haja a unidade formal e a harmonia de convivência entre as arquiteturas das várias épocas. A superação desta paradoxal independência acontece com as exigências contemporâneas em relação à preocupação ambiental, e, para Zevi, esta preocupação ambiental e os problemas enfrentados advêm especialmente da especulação imobiliária ligada ao urbanismo e não às questões artísticas.

"La 'rottura', lo scempio è operato nella stesura del programma edilizio e non há nula a che vedere con la natura del linguaggio architettonico. [...] gli architetti veramente moderni si battono dovunque sul terreno urbanístico per difendere gli ambienti antichi e spesso rinunciano a costruire pur di non assecondare l'azione vandálica della speculazione. La conclusione è evidente: la lotta contro i programmi edilizi che offendono i centri storici trova gli architetti moderni perfettamente allineati com Brandi sul tema della consertvazione."100

99 Idem, p.359.

100 ZEVI, Bruno. Visione prospettica e spazio-temporalità nella'architettura moderna. L'Architettura Cronache e Storia, n.111, 1956, pp.322-323. 
Anos depois, Zevi reformula a sua postura. ${ }^{101}$ Modifica sua crença anterior em relação à inserção da arquitetura moderna em centros históricos. As experiências de "ambientação" da arquitetura moderna criam exatamente o que Brandi preconizava anteriormente. 0 que se percebe ao invés da harmonia é 0 recíproco deterioro das duas partes: a arquitetura antiga torna-se totalmente deturpada pela inserção do novo, assim como a arquitetura moderna tenta sustentar um diálogo inexistente. Com esta confirmação, Zevi apresenta a proposta de zoneamento das cidades segundo diretrizes desta convivência. Chega então a proibir qualquer tipo de inserção do novo nos ambientes antigos valendo-se do método da repristinação, ou mesmo do preenchimento da lacuna por áreas verdes em casos sem solução. Logo concebe mais duas zonas, uma intermediária de encontro e contrastes entre 0 antigo e o novo, e a zona "liberada" do vínculo com a cidade antiga - lugar onde a criatividade e a inovação são totalmente livres de precedentes. Há então um rompimento entre o antigo e o novo, uma divisão dos problemas num caminho análogo ao que preconizava Marcello Piacentini nos anos 1940.

No mesmo ano, contra esta visão de Zevi, escreve Roberto Pane. Em primeiro lugar, o que pode assegurar que a liberdade inventiva seja sinônimo de qualidade? Será que a poética racionalista também não entrou na produção como questão de consumo? E o que dizer da arquitetura moderna "ambientada"? Será que não é um caminho menos doloroso (ao menos enquanto retórica) de um processo de especulação imobiliária?

Para Pane, a responsabilidade dada à questão ambiental é uma busca pela qualificação que grande parte da arquitetura moderna não soube produzir. Da outra parte, da tutela do patrimônio, é duvidoso o critério adotado em relação ao conhecimento do valor cultural a ser preservado. Para o arquiteto, o problema decorre de questões advindas de várias partes. Por isso, aponta vários problemas na alocução de Zevi e sua proposta das três zonas com tratamentos diversos. Acredita que a tentativa de esquematizar e reduzir o problema ao zoneamento, simplificando a leitura do tecido, é, na verdade, uma forma de ignorar o problema. Em primeiro lugar, a definição da primeira zona - a antiga pressupõe a definição desta como aquela "autenticamente antiga". "Vorrei

101 ZEVI, Bruno. Contro oghi teoria dell'ambientamento. L'Architettura Cronache e Storia, n.118, 1965, pp.212-13. 
sapere dove esistono ambiente autenticamente antichi" ${ }^{102}$, exclama Pane. E a outra zona, a segunda, é considerada aquela onde há o antigo e o novo, "il cui il tessuto è giá manomesso"103. Retoma-se a pergunta: que cidade tem esta caracterização tão certeira e simples? Por fim, o que garante que a cidade da terceira zona, aquela livre de qualquer vínculo, pode ser melhor qualificada? Através destes pontos, Pane aponta que a questão está exatamente em entender que 0 ambiente antigo assume um significado simbólico, o que significa ter a capacidade de assegurar a continuidade da cultura e das evidências de nossas raízes. 0 que se conclui é que existe um problema ignorado, ou posto como álibi de outros valores (econômicos, turísticos, etc). Pane acredita que é necessário considerar o problema e suas consequêencias como decorrentes do valor cultural.

Através desta retrospectiva de Pane podemos retomar algumas considerações sobre as intervenções urbanas no Brasil, que serão mais adiante esboçadas. 0 principal ponto levantado diz respeito ao modo de simplificação da questão na consideração do convívio entre o antigo e o novo como uma resposta simplesmente advinda do repertório urbano, o que será possivel perceber nas resoluções do Sphan em Ouro Preto, por exemplo. No entanto, Pane sinaliza outra perspectiva: aquela que aponta para outra direção, a da responsabilidade dada aos arquitetos e suas invenções individuais. Este problema, contudo, aparece mais adiante.

As passagens que remontam à década de 1960 são ensaios que parecem antever uma discussão ainda hoje tão emblemática. Estas posturas de confronto seguem desenvolvimentos diversos e conduzem, como já foi dito, algumas 'vertentes' hoje enunciadas. No entanto, não se trata de voltarmos a eleger o tipo de 'vertente' a que estamos dispostos a nos enquadrar; trata-se de uma questão de método e da capacidade crítica do profissional ao enfrentar as demandas hoje tão evidentes - que não apenas se restringem ao projeto do novo, mas constantemente se deparam com a tênue relação entre 0 antigo e 0 novo, além da importância da preexistência como dado sobre a memória e os valores simbólicos. É importante ter em mente a ressalva colocada até então de que tal processo segue um empenho de ordem conservativo por evidenciar-se

102 PANE, Roberto. Antico e nuovo. Casabella, n. 297, 1964.

103 Idem. 
como ato cultural e por ter como tarefa a transmissão para as futuras gerações deste testemunho material. Este ato não significa, em momento algum, a redução ou a inibição da criatividade, e sim mais um elemento que deve ser considerado no exercício de projeto.

Efetivamente as propostas e predileções sobre a questão dos conjuntos urbanos como detentores de valores patrimoniais e mesmo museais ganham respectivo status somente a partir da década de $1960^{104}$. Ao prolongar o objeto de intervenção em áreas ou fragmentos de cidade nota-se que, além de ampliar a escala referencial do objeto, defronta-se com outras questões advindas das próprias características urbanas e, por conseguinte, outros termos são colocados em pauta. A ampliação do objeto significa algo além da mudança de escala; significa preservar as características que a própria cidade apresenta como lugar das contradições, da convivência constante de várias estratificações temporais, do confronto entre diversos interesses e representações simbólicas. Ampliar o objeto significa também dilatar o sentido de preservação e conseqüentemente de toda ação decorrente deste ato.

O grande problema enfrentado na ampliação do objeto é lidar com as híbridas abordagens e as disparatadas metodologias decorrentes dessas diferenças. Verifica-se que os conceitos estabelecidos que fundamentam a prática de intervenção aparecem quase sempre sob termos genéricos ('qualidade', 'respeito', 'sentido') ou se apropriam de princípios referentes às normas urbanas para construir uma justificativa objetiva - para não somar as categorias referentes ao próprio desejo de continuidade de poder das classes dominantes sobre 0 território. Esta confusão sobre as justificativas metodológicas gera inúmeros problemas no processo de intervenção: desde 0 critério de seleção, passando pelos meios e instrumentos de salvaguarda e proteção, os resultados formais obtidos nas intervenções até a forma de percepção daquele objeto mnemônico pela população mais diretamente envolvida.

Apesar do fato garantir a valorização deste assunto, esta ampliação do objeto de interesse patrimonial também vem acarretar diversos males ainda em

104 A Carta de Veneza amplia a noção de monumento histórico. Não compreende apenas a edificação isolada, mas o sítio urbano ou rural de uma situação significativa ou acontecimento histórico. Os sítios urbanos são conservados e restaurados conforme as indicações usadas nos monumentos isolados. Idem. 

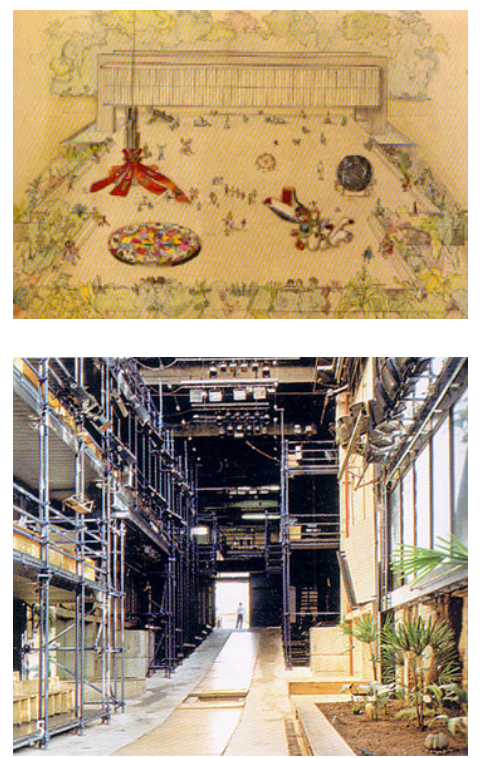

Fig.15. Desenho de Lina do Belvedere como uma grande praça.

Fig.16 "Palco-rua" do Teatro Oficina disritmia. O progressivo exílio do valor memorial do monumento e a universalização do patrimônio são caminhos crescentes de distanciamento dos princípios teóricos norteadores de sua existência e da atividade prática. Intensifica-se a problemática à medida que se adquire maior amplitude nos objetos de interesse patrimonial, como a escala dos conjuntos urbanos, por exemplo. Os problemas enfrentados enquanto métodos de intervenção que permitem a ativação da memória em escalas menores, em situações isoladas, pioram na medida em que avançam sobre situações mais complexas, o que colabora inevitavelmente com as ações depreciativas ou condições especulativas.

A arquitetura de Lina supõe a cidade e esta característica, como vimos, também é reflexo de uma geração. Esta preocupação em tratar aqui a idéia de arquitetura/cidade evidencia a dificuldade em considerar um estudo que pressuponha separadamente os "projetos urbanos"105, porque a relação da arquitetura proposta com a cidade existente sempre se dá. Os limites e as regras urbanas são exatamente a medida da criatividade.

"E a cidade não se faz negando-a: pois que não existe o terreno ideal para a arquitetura ideal. Tal abstração é recusá-la, fechar os olhos e voltar as costas ao ambiente onde vivem tantos homens; e 0 arquiteto é porque trabalha para seu concidadão. A cidade não limita 0 arquiteto; ao contrário, incentiva a sua criatividade, e lhe dá sua real dimensão de responsabilidade e humildade: nem tudo podemos." ${ }^{106}$

Algumas justificativas sobre a escolha dos projetos aqui analisados, 0 Centro Histórico de Salvador e o a proposta para o Concurso: Vale do Anhangabaú, apontam considerações que não devem ser ignoradas no seu desenvolvimento. Primeiramente, a justificativa da dimensão urbana dada a priori como motivação para o recorte aqui proposto. De fato, na maioria dos projetos realizados pela arquiteta Lina a relação estabelecida entre o objeto isolado e os problemas próprios da cidade é visível; neste aspecto, o MASP e o Teatro Oficina são exemplos bastante significativos, pois nestas duas propostas podemos identificar respectivamente um "museu-praça" e um "teatro-rua", sugerindo a interlocução entre arquitetura e cidade. Isto acontece porque é perceptível a designação direta que a condição urbana coloca nestas criações

\footnotetext{
105 Termo usado no título do projeto de pesquisa.

106 ZEIN, Ruth Verde. Fábrica da Pompéia, para ver e aprender. Revista Projeto, São Paulo, n.147, jan-fev, 1992.
} 
arquitetônicas. Como diz Lina: "Eu nunca quis fazer o maior vão livre do mundo, só que havia a doação do terreno que impunha como condição para seu uso a manutenção de um belvedere com vista para São Paulo."107. Ainda valendo-se das palavras da arquiteta, "a Arquitetura é, evidentemente, uma expressão do urbanismo, sendo necessário considerá-la, por isso mesmo, como parte de um todo, do conjunto urbanístico, e não como um fato avulso". ${ }^{108}$ Esse pressuposto urbano confere à arquitetura um status coletivo, o que evidencia a responsabilidade ética do arquiteto na construção do espaço urbano como lugar das relações sociais.

A hipótese sugerida é a de que essa enorme facilidade em lidar com os limites da cidade e sua condição preexistente configura-se como uma característica adquirida em sua formação romana, reiterada pela experiência profissional da geração do pós-guerra e, finalmente, pelo contato com a arquitetura moderna e um ideal político-cultural específico da década de 1940/50.

\section{a cultura popular como tema}

Como primeiro aporte da cultura popular na Itália pode-se considerar a atenção dos arquitetos italianos do início do século XX para idéias vindas da Inglaterra. Através de Alfredo Melani as publicações inglesas ganham o respectivo destaque. ${ }^{109}$ Conforme o estudo de Maria de Fátima Campello, a Inglaterra mostra-se atenta à inovação da arquitetura ao mesmo tempo em que direciona a atenção às tradições locais. 0 foco dado à arquitetura doméstica tem como propósito construir uma linguagem ao mesmo tempo moderna e particular, ou seja, nova sem perder a nacionalidade. Esta preocupação, como já colocado, percorre diversos caminhos conforme a constante mudança das cidades no fim do século XIX.

Também sobre esta interação ítalo-saxônica, não se pode deixar de apontar o interesse da Roman Associzione Artística fra i Cultori de Architettura

107 BARDI, Lina Bo. Uma aula de arquitetura. Revista Projeto, São Paulo, n.142, jan-fev, 1992.

${ }^{108}$ BARDI, Lina Bo. Contribuição..., op.cit., p.13. Ver também p.48.

109 Conforme Campello, a arquitetura vernacular inglesa é divulgada em artigos de Paul Sédille na Gazette de Beaux-Arts. Estes artigos são reunidos no livro L'architecture anglaise. Outro trabalho de referência é a publicação de Hermann Muthesius na Alemanha, The english house. Ver: CAMPELLO, Maria de Fátima. Op.cit, p.37. 
por John Ruskin e sua atenção voltada à "arquitetura menor". Conforme já apontado anteriormente, tanto Piacentini como Giovannoni estão diretamente envolvidos com o tema. Estes dois professores da Escola de Roma seguem os estudos sobre a tradição compositiva das cidades italianas através do interesse estético dos conjuntos. A técnica do diradamento proposta por Giovannoni aceita as modificações urbanas através de mínimas demolições necessárias na medida em que se assegura a possibilidade de leitura da unidade orgânica do sítio. A arquitetura vernacular é aquela que estabelece uma continuidade formal e material homogênea e que possibilita valorizar os importantes edifícios monumentais. As subtrações do tecido urbano, sempre as mínimas necessárias, dão lugar a pequenas áreas de luz ou praças. Do outro lado, as adições devem receber atenção, uma vez que não podem romper com a continuidade da "arquitetura menor", ou seja, devem ter o máximo de neutralidade possível. 0 valor da arquitetura anônima na concepção geral do conjunto ganha aqui o seu mais precioso interesse. Os novos edifícios têm como principal problema a continuidade harmônica do conjunto e, portanto, as lacunas devem seguir exatamente as características desta arquitetura simples e popular. No entanto, Giovannoni não acredita na imitação ou na idealização desta arquitetura - aos moldes dos procedimentos de Viollet-le-Duc. Conforme afirmado anteriormente, seu procedimento segue uma linha conciliatória entre o que se preconizava até então sobre a Teoria da Restauração. Dessa forma, o procedimento mais adequado é simplificar as geometrias das arquiteturas anônimas e tradicionais. A distinção entre 0 antigo e o novo é anunciada de forma bastante cuidadosa. Além dos respeito aos materiais, conserva-se principalmente os elementos compositivos que as identificam como tipologias tradicionais, como os balcões, as loggias, etc.

É neste sentido que tanto Giovannoni como Piacentini promovem estudos e a divulgação da arquitetura vernacular italiana. Conseqüência deste interesse é a introdução destas questões no âmbito das disciplinas cursadas na Escola de Arquitetura de Roma. No entanto, a questão da arquitetura vernacular tem outros desdobramentos e interesses. Nota-se que como pano de fundo e como ambiente que valoriza os monumentos, a arquitetura anônima ganha outra abordagem, o que provoca um salto no modo de sua referência, como se percebe nas questões trabalhadas por Giuseppe Pagano. A arquitetura 
vernacular torna-se questão de principal interesse para a construção da genealogia dos valores da arquitetura moderna italiana. Em geral, a busca de uma linguagem moderna na Itália é constantemente elucidada pelo retorno às raízes culturais particulares e tradicionais. No entanto, a forma como se efetiva esta preocupação parece modificar-se conforme o espaço-tempo. Também Campello demonstra que se pode admitir um paralelo em relação a esta pesquisa sobre a "verdadeira genealogia da arquitetura italiana" no trabalho de Giuseppe Pagano na década de 1930 - momento em que Lina ainda cursa a Universidade. Este arquiteto, responsável pela Mostra di Arquitettura Rurale montada na Trienal de arquitetura em Milão, em 1936, é responsável pela divulgação da arquitetura anônima na Revista Casabella - com um ângulo de visão sobre a "arquitetura menor" já distinto daquele proporcionado pelos professores Giovannoni e Piacentini.

O trabalho de Pagano consiste na seleção de algumas construções vistas em suas andanças pelo interior da Itália e que para ele representam uma necessidade pura, simples e econômica da arquitetura. Seria possível identificar na arquitetura rural a conservação de soluções "espontâneas" para determinadas condições climáticas, econômicas e culturais. Esta coletânea apresentada por Pagano evidencia uma genealogia aproximativa das necessidades da arquitetura moderna - declarada por alguns como momento fundamental na experiência racionalista italiana. Esta arquitetura espelharia as necessidades primordiais do homem em sua razão original - necessidades estéticas e morais -, constituindo-se em referência significativa para a concepção da arquitetura moderna italiana.

0 tema da arquitetura vernacular assume 0 debate nas revistas mais importantes da Itália no período e se constitui como um fato marcante para a geração da arquiteta Lina. A arquitetura anônima e a genealogia da arquitetura moderna são também objetos de investigação da arquiteta já no início da década de 1940, quando recém-formada. Depois dos estudos em Roma, Lina se transfere para Milão onde inicia a atuação profissional através de colaborações em revistas. Seus primeiros ensaios jornalísticos são publicados na Revista Grazia juntamente com o amigo Carlo Palanti. Os textos de Lina sobre o assunto aparecem também quando a arquiteta assume a co-direção da Revista 
Domus ${ }^{110}$, pouco antes do início da Segunda Guerra Mundial. A arquitetura vernacular e a cultura popular são constantes em seus trabalhos editoriais na Itália e persistem como tema também aqui no Brasil, quando Lina assume a direção da Revista Habitat, na década de 1950111.

A experiência da guerra também pode ser considerada um momento de modificação dos esquemas propostos por seus professores em Roma em sua fase propedêutica. Conforme Lina, "A guerra destruiu os mitos dos 'monumentos"112. Portanto, prevalece a conduta ética do arquiteto; a honestidade para com as necessidades reais do homem - necessidades materiais e espirituais; o status coletivo da arquitetura; a concretização da realidade e não a mera abstração. Entender a realidade telúrica da cultura significa adentrar no campo da cultura popular e nas tradições vernaculares de outra forma - que não folcloricamente. Aqui é necessário entender que a questão da cultura popular e das tradições vernaculares constantemente evocadas por Lina decorre de sua experiência italiana, mas possui desdobramentos próprios, devido a aproximações com as posições de outros autores, além do encontro com a historiografia da arquitetura moderna brasileira - em que a cultura popular é analisada por Lucio Costa, enfocando outros aspectos $^{113}$-, e, principalmente, de sua experiência em Salvador. ${ }^{114}$

Neste ponto, faz-se necessário um esclarecimento, lembrando que é na década de 1940 que alguns acontecimentos colocam em pauta o tema da cultura popular: são publicadas as memórias póstumas de Antonio Gramsci; Giuseppe Pagano é morto num campo de concentração; Lina, Carlo Pagani e Bruno Zevi coordenam a Revista $A$ - revista concentrada em artigos sobre a modernidade na vida cotidiana. Mais adiante os temas são retomados. 0 que é importante destacar é que a emergência da cultura popular como problema intelectual italiano viabiliza-se em função de diferentes frentes e acontecimentos. Esta

\footnotetext{
110 Revista dirigida por Gió Ponti.

111 Ver PEREIRA, Juliano A. Op.cit., pp.26-49.

112 BARDI, Lina Bo. Na Europa a casa do homem ruiu. Rio, n.92, fev, 1947.

113 É importante notar que o tema da cultura popular tem abordagens diversas entre os arquitetos. Enquanto Lucio Costa organiza a historiografia da arquitetura moderna brasileira em torno do aspecto técnico da tradição e da cultura popular, Lina desenvolve o raciocínio a partir da relação entre artesanato e indústria, da produção (design) envolvida pelo "saber fazer" popular. Sobre o assunto destaca-se ROSSETI, Eduardo Pierrotti. Tensão moderno/popular em Lina Bo Bardi: nexos da arquitetura. Disponível em http://www.vitruvius.com.br/arquitextos/arq000/esp165.asp. Acesso em 12/05/2006; ANELLI, Renato. Op.cit., pp.64-81.

114 Sobre 0 assunto ver ROSSETI, Eduardo. Tensão..., op.cit.
} 
questão é efetivamente destacada nas discussões italianas principalmente pelo enorme impacto produzido pela guerra. Também é interessante notar que o tema da cultura popular surge num contexto análogo às vanguardas arquitetônicas brasileiras, em que, como já observado, se destaca Lucio Costa, arquiteto que procura na cultura popular os aspectos técnicos afinados com os objetivos da modernidade. É assim que Lina, através de matrizes culturais externas, encontra no Brasil uma condição favorável para a continuidade de sua reflexão sobre a cultura popular e toda a discussão sobre a preexistência que ela suscita. ${ }^{115}$.

Não se pode deixar de considerar que o tema da cultura popular tem desdobramentos mais amplos no período. O contexto político-cultural italiano deve ser considerado neste amadurecimento teórico. Um autor importante para a consideração desta discussão é Antonio Gramsci, fundador do Partido Comunista na Itália, o que o torna conhecido no meio italiano como importante personagem do contexto político-cultural local. Há documentos que supostamente podem comprovar referências diretas de Lina a este autor. Por ocasião da visita a Salvador, em 1958, para proferir uma palestra, há registros de que a arquiteta faz referência ao pensamento gramsciano. É na década de 1940 que se publica na Itália a obra Quaderni del Cárcere. É importante observar que o primeiro volume desta obra faz consideração sobre a concepção de mundo identificada com a realidade do "fazer humano" - concreto, econômico e produtivo - em contraponto com o fazer abstrato e ideal. Ataca-se também a organização da cultura e a visão constituída dos intelectuais como grupo social independente e autônomo. Os escritos de Gramsci remetem-nos ao princípio desta discussão, sobre a importância do exame crítico da realidade:

"Compreender e avaliar realisticamente a posição e as razões do adversário (e por vezes é adversário todo o pensamento passado) significa precisamente terse libertado da prisão das ideologias (no sentido pejorativo do termo, de cego fanatismo ideológico), isto é, por-se de um ponto de vista 'crítico', o único fecundo da investigação científica"116

Também se trata da busca de uma cultura que advenha das necessidades objetivas históricas coletivas e não como algo ideal difundido por alguns poucos indivíduos pertencentes a uma dada categoria intelectual (concatenados pela própria classe intelectual). Nos textos de Gramsci, verifica-

115 Idem.

116 GRAMSCI, A. Problemas de filosofia e história In: Obras escolhidas. São Paulo: Martins Fontes, 1978, p.41. 
se a definição de alguns termos usados constantemente pela arquiteta como folclore/artesanato, a diferença entre nacional-popular e nacionalista e a perspectiva política da ação intelectual. A própria noção de pedagogia crítica e educação popular corroboram com a postura já descrita sobre as características dos museus defendidas pela arquiteta: pedagógicos e não conservativos no sentido de "guardiões de relíquias". Também é possível fazer uma aproximação entre a visão de ensino a partir da relativização da história e a relação entre teoria e prática implícita nos textos. Ao comparar a noção de "filosofia criativa" de Gramsci e a definição de estética dada por Lina pode-se identificar o conteúdo político-cultural subjacente, desvinculado das regras acadêmicas, do abstracionismo ou classes intelectuais. O exame crítico pressupõe a desconstrução do preconceito de classe ou das regras que impedem 0 pensamento racional científico. Fica explícito neste trabalho da arquiteta Lina 0 sentido atribuído ao termo "estética", desvinculado da metafísica ou de um tipo de sistema de ensino progressista:

'O termo 'estética' adotado para caracterizar este [sic] curso, não deve ser entendido como 'filosofia da arte', mas como uma síntese de teoria e prática, incluindo, pois, não somente as idéias [sic] que, no decorrer da história [sic] em seus vários [sic] períodos, vigoram com referência à arte, mas também a própria [sic] 'História da Arte' e evidentemente a história [sic] em geral, em seus vários [sic] aspectos, como digamos, história da cultura [sic], já que a história [sic] da arte separada das teorias que lhe correspondem, ou estas teorias em si sem concretização histórica [sic] da atividade artística [sic], representariam uma abstração avulsa da continuidade histórica [sic] e destituída [sic] de interesse atual." (grifo nosso) 117

\section{A "filosofia criativa" definida por Gramsci é:}

'[...] 'criativo', portanto, no sentido 'relativo', de pensamento que modifica o modo de sentir do maior número e portanto a própria realidade que não pode ser pensada sem este maior número. Criativo também no sentido que ensina como não existe uma realidade por si, em si e para si, mas em relação histórica com os homens que a modificam, etc." ${ }^{118}$

A relação entre o antigo e o novo colocada no escopo da formação da nova sensibilidade italiana no entre-guerras e reafirmada pela geração subseqüente constitui um corpo de questões elaboradas pela necessidade de lidar com a preexistência. Esta dialética só é possível se se analisar os elementos até aqui investigados, como o método crítico adotado e a noção de

117 BARDI, Lina Bo. Programa do Curso de extensão Universitária. São Paulo. Instituto Lina Bo Bardi e P. M. Bardi. (s.d.)

118 GRAMSCl, A. Op.cit, p.42 
história. Estes elementos redefinem uma nova sensibilidade desprovida de preconceitos e hierarquias 0 que possibilita admitir 0 respeito para com as diversas estratificações materiais e humanas no trato com a cidade. Dessa forma, a definição de cultura envolvida neste processo amplia-se agregando o fator político-social como questão proeminente e que encontra na cultura popular um modo de se relacionar com a realidade material existente e particular do lugar. Esta ampliação acaba solicitando a necessidade de se reconsiderar também os próprios moldes educacionais.

Talvez seja aqui o ponto de encontro entre os anseios modernos e a sua formação "tradicional" européia romana ${ }^{119}$. A crítica de Lina ao ensino romano está baseada nesta visão de classe do ensino. No entanto, a arquiteta admite a boa formação filológica por ela recebida durante 0 período propedêutico, o que a coloca numa posição confortável na atuação em preexistências, visível na atuação em Salvador, por exemplo. Depois de criticar os métodos de ensino que caracterizaram sua formação em Roma, Lina acaba por considerá-los importantes na medida em que lhe conferem um profundo instrumental de análise e atuação. Assim, a arquiteta reconhece a qualidade de seus mestres sob o ponto de vista filológico. ${ }^{120}$

A trajetória esboçada anteriormente sobre o enfrentamento da nova sensibilidade e o problema do método advém literalmente da relação entre cultura e técnica buscada pela geração de Lina.

Anelli afirma que para entender a mudança pretendida no âmbito da cultura pela arquiteta é imprescindível colocá-la ao lado de Pietro Maria Bardi, uma vez que ambos afirmam a proposta de transformar um meio provinciano -

\footnotetext{
119 Maria de Fátima Campello cita duas passagens em que se revela o descontentamento de Lina perante a escola romana de arquitetura, a qual não corresponde a seus anseios de modernidade: "A tendência daquela faculdade, cujos reitores foram Gustavo Giovannoni e Marcello Piacentini se dirigia precipuamente para a indagação histórica: as disciplinas histórico-arquitetônicas eram consideradas mais importantes do que a Composição. O fato de ser Roma um dos centros da cultura clássica fazia com que os alunos, durante o biênio propedêutico dedicado às disciplinas: História dos estilos [sic], Elementos de Composição, Relevo [sic] dos Monumentos, aplicassem a maior parte do tempo o seu estudo ao relevo [sic], bem como do desenho ao natural e à observação dos monumentos antigos. No triênio de aplicação, a restauração de monumentos, ensinada por Gustavo Giovannoni, adquiria proporções preponderantes com referência às outras disciplinas, bem com a História da Arte, ensinada no período propedêutico e desenvolvida especialmente no tocante à História da Arquitetura." TENTORI, Francesco. Uma lettera da São Paulo - ritrattini de '900 italiano. Florença, Facoltà de Architettura - Universitá degli Studi di Firenze, p.5-6 apud CAMPELLO, Maria de Fátima. Sobre esta impressão da faculdade também ver BARDI, Lina Bo. A Catedral. Habitat, n.14, jan-fev, 1954.

120 "Era bravo do ponto de vista filológico, e a filologia - de resto - é o que conta mais" TENTORI, Francesco. Op.cit, p. 6. apud ANELLI, Renato. Interlocução ..., op.cit.
} 
visto como capaz de avançar num processo de modernização autônomo e original.

"A natureza da ação de Lina Bo se confunde com a de Pietro Maria Bardi, e não se refere mais à 'síntese das artes', como ocorria com os arquitetos que apresentei anteriormente. Constitui um conjunto de ações em várias áreas com um mesmo objetivo. Apresenta características de um profissional versado nas várias artes decorativas, mas seus objetivos e estratégias pretendem a construção de uma cultura moderna que efetivamente transforme a sociedade, demonstrando um caráter formado durante os anos da guerra."121

Portanto, somado ao problema da nova sensibilidade e do método colocados até aqui, Lina traça um caminho entre o popular e o erudito' ${ }^{122}$. A busca por uma cultura autêntica e ao mesmo tempo moderna é relevada no sentido do uso cotidiano espontâneo. Nesta visão, a preservação do patrimônio cultural ganha sentido na apropriação dos valores e significações próprias em permanentemente modificação que a população estabelece com suas dinâmicas cotidianas. O passado herdado é traduzido através da análise das "práticas sociais"123. Conforme as colocações de Enzo Paci: "I'equilibrio estético, I'armonia è una sintese dinâmica tra una possibilità nuova e il condizionamento della tradizione di cui il valore è riconosciuto próprio in quanto la nuova funzionalità non si pone como astratta ma come effettivo rinnovamento in una continuita""124. É neste sentido que se considera Lina um personagem atuante no âmbito cultural, muito mais do que apenas ligada à arquitetura, exatamente porque procura "compreender a arquitetura dentro de um sistema cultural permeável e diagonal." $" 125$

"Procurar com atenção as bases culturais de um País, (sejam quais forem: pobres, míseras, populares) quando reais, não significa conservar as formas e os materiais, significa avaliar as possibilidades criativas originais. Os materiais modernos e os modernos sistemas de produção tomarão depois o lugar dos meios primitivos, conservando, não as formas, mas a estrutura profunda daquelas possibilidades." 126 (grifo do autor)

\footnotetext{
${ }^{121}$ ANELLI, Renato Luiz Sobral. Op.cit., .p.39.

122 Pode-se dizer que a preocupação de Lina Bo Bardi em resolver a questão da indústria e o artesanato inicia-se com o contato com Giò Ponti e o contexto italiano. Os números relativos aos anos de 1950 da Revista Habitat trazem uma amostra destas preocupações. Sobre o tema destaca-se também: CAMPELLO, Maria de Fátima.Op.cit., p.38-39; ROSSETI, Eduardo Pierrotti. Op.cit.

${ }^{123}$ ARANTES, Antonio Augusto. Paisagens Paulistanas. São Paulo: Imprensa Oficial, 2000.

124 PACl, Enzo. II cuore della città. In: Casabella Continuitá, n.202 ago-set, 1954, p.IX..

125 WISNIK, Guilherme. Lina Bo Bardi: a interpretação cultural do Brasil 'pós-Brasilia'. Folha de São Paulo, Caderno llustrada, quarta-feira, 11 de janeiro de 2006. Segundo o autor, a arquitetura após o golpe de 1964 encontra-se despreparada para enfrentar a industrialização e o projeto desenvolvimentista e é sobre esta preocupação que Lina se debruça.

126 BARDI, Lina Bo. Tempos de Grossura: o design no impasse. São Paulo: Instituto Lina Bo e P. M. Bardi, 1994. p.21.
} 
Lina chega ao Brasil em 1946. Inserida no contexto brasileiro de abertura à indústria e ao desenvolvimento do país, Lina percebe a invasão também de outros parâmetros culturais ligados principalmente aos interesses econômicos envolvidos e à lógica do consumo. Frente à força dinâmica do mercado e às estratégias publicitárias vive-se uma promulgação de parâmetros externos de usos e costumes, o que vai contracorrente àquilo que se preconiza para a produção e o desenvolvimento através do repertório cultural autóctone e ligado a nossa realidade. Claramente se percebe a impossibilidade de reação, inclusive da arquitetura, pois são deixados de lado os nossos reais problemas em prol do desenvolvimento a todo custo. A formação de Lina adquirida no contexto italiano antevê a necessidade fundamental de buscar alternativas para o desenvolvimento através do retorno às nossas raízes culturais para a produção industrial em larga escala. No entanto, Lina percebe a fragilidade (ou inexistência) do artesanato ${ }^{127}$ no Brasil e, portanto, a complexidade de se promover este salto artesanato-indústria.

"Esse é o impasse claramente percebido por ela entre os anos 50 e 60: 0 Brasil, sendo mais africano do que 'ocidental', é um país onde a seiva da cultura popular não se esterilizou, como na Europa do pós-guerra. No entanto, o problema da verdadeira industrialização tinha fatalmente que ser enfrentado, e uma importante escolha histórica estava em vias de se realizar: ou o salto do pré-artesanato doméstico a um desing brasileiro efetivo, aderente à espessura da cultura cotidiana do país, ou uma abertura indiscriminada ao universo dos objetos de consumo, à pasteurização kitch - vale dizer, à ausência de planejamento habitacional-popular, à especulação imobiliária etc. Se o ponto de vista de fundo, aqui, é nitidamente marxista, temperado pela valorização italiana do artesanato, a operação conceitual é antropofágica: a transformação do atraso em instrumento de sua própria superação, isto é, em originalidade vital." 128

O popular para Lina é tudo o que se relaciona com os problemas reais de determinado tipo de vida, portanto honesto com as necessidades atuais. É essa a herança que Lina quer conservar, herança vista como algo construído pela necessidade presente, totalmente oposta ao folclore (herança estática e

$127 \mathrm{O}$ artesanato mantém um forte vínculo cultural local através da sua existência decorrente de uma necessidade, do uso de materiais e principalmente pelo modo de se fazer os objetos passados de geração para geração. Na Europa, o artesanato pode colaborar com as novas proposições uma vez que contém uma continuidade implícita que deveria permanecer no salto para a industrialização.

${ }^{128}$ WISNIK, Guilherme. Op.cit. 
regressiva).129 Há, conseqüentemente, um sentido de permanência, de continuidade da tradição implícita na produção moderna - entenda-se aqui por tradição aquilo que provém muito mais das condições imateriais: da necessidade e do saber fazer. Portanto, a retroversão tem um propósito claro, racional e objetivo em relação à revisão do presente. Com isso, mais uma vez é possível afirmar que o diálogo entre 0 antigo e o novo no trabalho de Lina se dá muito mais através desta luta lançada (pelo casal) em busca de um país moderno e original, ou seja, muito mais pela experiência do que por uma abordagem vinda de uma trajetória acadêmica.

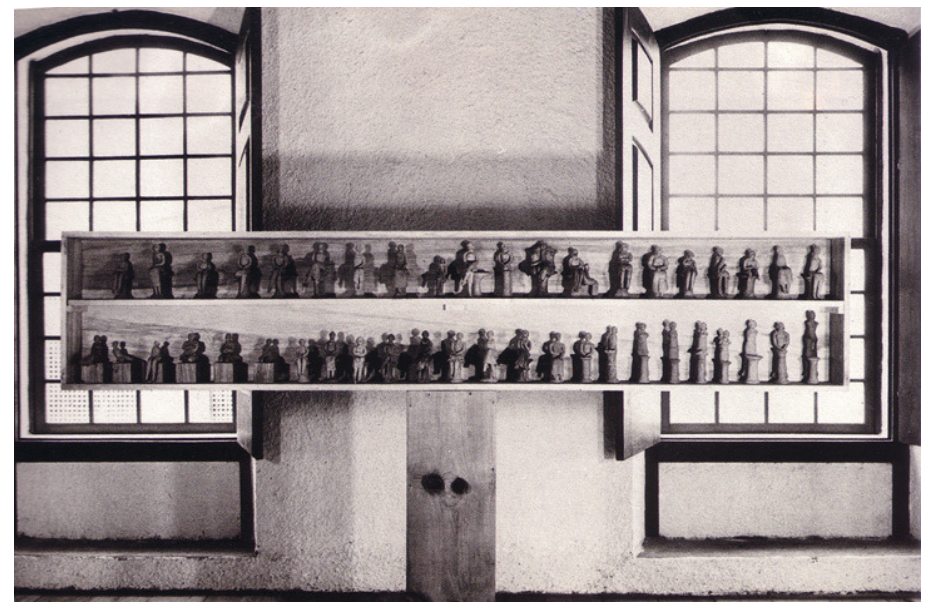

Fig.17 Maneira de expor: através da sobreposição e da simultaneidade. Solar do Unhão. presente histórico

O que Lina assimila e propõe não é uma retomada do passado ${ }^{130}$ pura e simplesmente, mas "[...] uma espécie de medida, naturalmente crítica que, levando em consideração a história como herança e continuidade, abra as mais amplas liberdades às possibilidades do arquiteto, hoje mais do que nunca mediador responsável pelo "modo de viver" dos homens"131.

É neste sentido que a noção de "presente histórico" encontrada nas afirmações de Lina não pode ser vinculada diretamente à noção de memória, como é comum encontrar na bibliografia sobre a arquiteta. Deve, no entanto, ser aproximada à noção de história empregada por Benedetto Croce. Entende-se aqui que a noção de "presente histórico" deve ser vista como uma apropriação

\footnotetext{
129 Lina desenvolve o tema da oposição entre artesanato e folclore em vários textos, dentre eles: BARDI. Lina Bo. Tempos..., op.cit., pp.20-21; BARDI, Lina Bo. Apresentação-Manifesto da Exposição de Arte Popular do Unhão. Revista Mirantes das Artes, n.6, novembro de 1967.

$130 \mathrm{O}$ exame do passado em Lina é fundamental. Nunca o antigo aparece em suas colocações de modo contemplativo, mas sempre de forma crítica. Olívia Oliveira diz: "Ou seja, Lina, 'o arquiteto', vê na sua relação com o passado não uma reconstrução arqueológica mas, sim, uma análise construtiva, um trabalho de vivificação, de rejuvenescimento, de 'posta à ordem do dia', parafraseando Walter Benjamin". OLIVEIRA, Olívia Fernandes. Quarto..., op.cit.

131 BARDI, Lina Bo. Contribuição..., op.cit., p.51.
} 
do que se preconiza sobre a história como prática científica: através de seu cunho crítico e consciente ${ }^{132}$. Conforme Jacques Le Goff,

"a idéia da história dominada pelo presente baseia-se na célebre frase de Benedetto Croce em La storia come pensiero e como azione, que considera que 'toda história é história contemporânea.' Croce entende por isso que 'por mais afastados do tempo que pareçam os acontecimentos de que trata, na realidade, a história liga-se às necessidades e às situações presentes nas quais esses acontecimentos têm ressonância'. De fato Croce pensa que, a partir do momento em que os acontecimentos históricos podem ser repensados constantemente, deixam de estar 'no tempo'; a história é o 'conhecimento do eterno presente"'.133

A confusão entre história e memória confirma-se nos artigos alusivos ao tema, quando a referência usada para a definição do termo "presente histórico" encontra similaridades na definição de memória, principalmente em relação à construção presente dos fatos passados. Os significados são verdadeiramente opostos, apesar de evocarem a atualidade do passado e de compartilharem a recíproca solidariedade entre termos ${ }^{134}$, e por isso acredita-se que seja necessário registrar tais considerações.

Destaca-se freqüentemente a referência a autores brasileiros para a definição do termo memória como aproximação da noção de "presente histórico".

132 A noção de "presente histórico" é bastante comentada nos estudos sobre Lina. No entanto, não há um aprofundamento sobre 0 assunto e muito menos um acordo sobre o seu significado. A pesquisadora Olívia Oliveira trata deste tema aproximando "presente histórico" de "memória". OLIVEIRA, Olivia F. Sutis substâncias da arquitetura. São Paulo: Gustavo Gilli; Romano Guerra, 2006. p. 353. Outro estudo, o de Ana Carolina Bierrenbach utiliza-se da filosofia da história e a noção de "tempo de agora" (jeitzeit) formulada por Walter Benjamin. BIERRENBACH, Ana Carolina de Souza. Os restauros de Lina Bo Bardi e as interpretações da história. Dissertação de Mestrado UFBA. Salvador, 2001, p.9. Considero, aqui, o termo "presente histórico" como algo muito mais aproximado da noção de "história", na medida em que a história tem ligação direta com 0 conhecimento presente, uma vez que os acontecimentos históricos podem ser re-interpretados. Cf. LE GOFF, Jacques. Memória e História. Enciclopédia Einaldi, p.162.

133 Idem.

134 Sobre o tema há uma extensa bibliografia, destaca-se: BOSI, Ecléa. Memória e sociedade: lembrança de velhos. São Paulo: T. A Queiroz Editora, 1979; O tempo vivo da memória: ensaios de psicologia social. São Paulo: Ateliê, 2003; HALBWACHS, Maurice. A memória coletiva. São Paulo: Vértice, 1990; JEUDY, Henri-Pierre. Op.cit; CUNHA, Maria C. P. (org). O Direito à Memória: Patrimônio Histórico e Cidadania. São Paulo: Departamento do Patrimônio Histórico, 1992; D’ÁLESSIO, Márcia Mansor. Memória: Leituras de M. Halbwachs e P. Nora. In: Revista Brasileira de História. São Paulo, v.13, n.25-26, set. 1993, p.98; LE GOFF, Jacques. História..., op.cit.; MENESES, Ulpiano T. B. A História, cativa da memória? Revista do Instituto de Estudos Brasileiros, v. 34, p. 9-23, 1992; NORA, Pierre. Entre memória e história: a problemática dos lugares. In: Projeto História: Revista do Programa de Estudos Pós-Graduação em História e do Dep. de História da PUC-SP. São Paulo, 1981; CUNHA, Claudia dos Reis e. A questão da memória e os instrumentos de rememoração. In: O patrimônio cultural da cidade de Sorocaba: análise de uma trajetória. Dissertação de Mestrado (Departamento de Fundamentos e História da Arquitetura e Urbanismo) FAU-USP, 2005 (a quem agradeço as tantas discussões sobre o tema e a disponibilidade da bibliografia). 
Usa-se, sobretudo, a definição de memória empregada pela psicóloga Ecléa

Bosi. Sobre o significado de memória, indica a autora:

"Na maior parte das vezes, lembrar não é reviver, mas refazer, reconstruir, repensar, com imagens e idéias de hoje, as experiências do passado. A memória não é sonho, é trabalho. Se assim é, deve-se duvidar da sobrevivência do passado, 'tal como foi', e que se daria no inconsciente de cada sujeito. A lembrança é uma imagem construída pelos materiais que estão, agora, à nossa disposição, no conjunto de representações que povoam nossa consciência atual." 135 (grifo nosso)

A memória existe porque é uma compilação recente de um fato vivido por determinado grupo. Depende, portanto, de inúmeros fatores para que se constitua: de meios presentes para rememorar, das experiências adquiridas por aquele grupo; por somas de sonhos e desejos do inconsciente.

"memória é a vida, sempre carregada por grupos vivos e, nesse sentido, ela está em permanente evolução, aberta à dialética da lembrança e do esquecimento, inconsciente de suas deformações sucessivas, vulnerável a todos os usos e manipulações, susceptível de longas latências e de repentinas revitalizações [...] é um fenômeno sempre atual, um elo vivido no eterno presente."136

A atualidade temporal existente na memória permite uma ilimitada possibilidade de lembranças tanto quanto o número de grupos que rememora. Conforme Márcia D’Alessio, "não há lembrança fixa, a multiplicidade está ligada ao rearranjo constante das emoções grupais, retirando do passado aquilo que ele tem na História: seu status ontológico ${ }^{137}$. (grifo do autor)

No entanto há que se diferenciar a história e a memória.

Para Jacques Le Goff a história é a forma científica da memória. ${ }^{138}$ Portanto, se memória é algo latente ao presente vivido e não tem consciência de ruptura entre o passado e o presente, se opõe deliberadamente à história - que necessita de fontes documentais, que é dependente da eleição de fatos e de um distanciamento temporal. Da mesma forma, Pierre Nora defende que "a história é a representação do passado. [...] A história, porque operação intelectual e laicizante, demanda análise e discurso crítico". 139

Como coloca outro autor, o professor Ulpiano Bezerra de Menezes:

"pode-se dizer que a memória não dá conta do passado, nas suas múltiplas dimensões e desdobramentos. E não só é claro, porque sabemos muito mais

\footnotetext{
${ }^{135}$ BOSI, Ecléa. Memória..., op.cit., p.17.

${ }^{136}$ NORA, Pierre. Entre memória..., op.cit., p.9.

137 D’ÁLESSIO, Márcia Mansor. Memória..., op. cit. 99.

138 LE GOFF, Jacques. História..., op.cit., p.535.

139 NORA, Pierre. Entre memória..., loc.cit..
} 
do que as memórias vivenciadas no passado poderiam saber, mas sobretudo porque o conhecimento exige estranhamento e distanciamento. Somente a História e a consciência histórica podem introduzir a necessária descontinuidade entre passado e presente: História, com efeito é a ciência da diferença."140

Mesmo considerando a memória como uma construção presente, ou ainda, dando-lhe um status coletivo, estas duas noções não podem ser confundidas. A diferenciação dada por Maurice Halbwachs entre memória coletiva e história é bastante contundente. Segundo o autor, a história é a escolha de fatos "que ocupam o maior espaço na memória dos homens."141

"Quando a memória de uma seqüência de acontecimentos não tem mais por suporte um grupo, aquele mesmo em que esteve engajada ou que dela suportou as consequêencias, que the assistiu ou dela recebeu um relato vivo dos primeiros atores e espectadores, quando ela se dispersa por entre alguns espíritos individuais, perdidos em novas sociedades para as quais esses fatos não interessam mais porque lhes são decididamente exteriores, então 0 único meio de salvar tais lembranças, é fixa-las por escrito em uma narrativa seguida uma vez que as palavras e os pensamentos morrem, mas os escritos permanecem."142

Ou seja, a história começa onde se apagam os vestígios de memória social143. A história depende de um exame filológico, cientificamente embasado e um método procedente.

O exemplo das premissas para a organização de uma Escola de Desenho Industrial em Salvador é importante para entender o que significa a constatação de que "a história começa onde se apaga os vestígios da memória social", anteriormente citada. Além disso, esta passagem enriquece o sentido de "presente histórico" atribuído pela arquiteta Lina. Em entrevista concedida ao então pesquisador Juliano Pereira, Mario Cravo e Renato Ferraz denunciam este propósito. ${ }^{144}$

"Ferraz: eu nunca pude perceber que D. Lina tivesse idéia de preservar esse tipo de coisa, ela pretendia transformar isso em Desenho Industrial.

Cravo: [...] e se não, não haveria transformação. Você tem que queimar uma coisa ou outra [...] veja bem: 0 conceito é que se vai desaparecer, se essas manifestaç̃os populares tem que desaparecer, por que não aproveitamos de

\footnotetext{
140 MENESES, Ulpiano T. B. A História..., op.cit., p.12.

141 HALBWACHS, Maurice. A memória..., op.cit., p.80.

142 Loc.cit.

${ }^{143}$ Cf. Halbwachs, idem, ibidem. Apesar de não ser assunto do trabalho, é importante lembrar que as ciências sociais contribuem para o entendimento da memória como fato extra-individual, dependente sempre de um determinado grupo.

${ }_{144}$ Mario Cravo Junior, artista, esteve ligado ao MAMB durante o período em que Lina o dirigiu, em 1964. Renato Ferraz é professor da UFBa e foi secretário geral do MAMB na mesma ocasião. PEREIRA, Juliano Aparecido. ANEXO III: Entrevista de Mário Cravo e Renato Ferraz. Op. cit.
} 
alguma forma e assassinamo-las? É isso ai, conscientemente. Eu acho que é um raciocínio válido. $E$ então, de certa forma, trazer esses mestres aqui para a cidade foi uma maneira de sacrificá-los. Esse negócio de saudosismo... se é preciso incorporá-los à estrutura da Universidade, da vida urbana, essas heranças que estão estendidas no interior e nas culturas mais afastadas, você trazendo esses mestres para cá, eles seriam automaticamente poluídos e transformados, é uma maneira de matar."(grifo nosso)

Ou seja, essa condição cultural existente não tem importância no seu isolamento em relação ao mundo que estaria por vir. Essa condição só faz sentido enquanto estiver fortalecida e reafirmada através da sua introversão $0^{145}$, sua atualização. Em outras palavras, enquanto memória coletiva estes modos de fazer estariam fadados ao desaparecimento com a abertura inescrupulosa do desenvolvimento proposto para o Brasil, uma vez que dependem consideravelmente de um espaço social, ambiental e econômico para se perpetuarem. A assimilação do "saber fazer" popular na proposta de Lina para a escola de desenho industrial acontece de forma consciente, ou melhor, científica, pois tem objetivo didático com um fim na produção atual. Este é o projeto para enfrentar a forte estrutura industrial a que 0 país estaria fadada. Conscientemente, Lina utiliza-se da memória, da herança, da tradição e retira 0 seu substrato: a matéria para construir uma história presente, um programa ligado às necessidades, telúrico e, portanto, vinculado ao passado ainda que vista como "presente-histórico". A continuidade histórica indicada por Lina é essa continuidade da necessidade encontrada na realidade do cotidiano, o que se aproxima da proposta inicial de Pagano na consideração da cultura popular como propulsora da criatividade e produção moderna. Ou seja, é a continuidade dos meios e não de seus produtos (folclóricos). É sintomático que o Museu de Arte Popular da Bahia e as Oficinas do Unhão pertencessem ao Museu de Arte Moderna da Bahia. O MAMB é inaugurado em 1960 com um acervo absolutamente reduzido e por isso não tem um sentido tradicional de museu, uma vez que pouco se poderia conservar. "suas atividades foram dirigidas à criação dum movimento cultural que assumindo os valores de uma cultura historicamente (em sentido áulico) pobre, pudesse lucidamente [...] apoiando-se

145 O que Mario Cravo chama de "assassinato" prefiro interpretar como "transformação". 


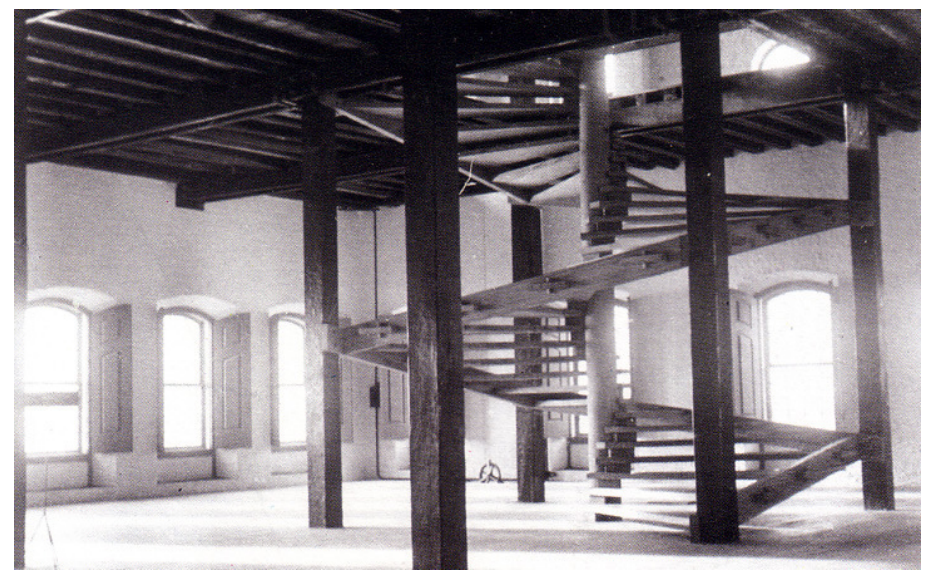

numa experiência popular [...] entrar no mundo da verdadeira cultura moderna."146

Novamente se percebe que 0 conceito de "presente histórico" é construído pela experiência do desing, impulsionado pelo objetivo maior da sua luta traçada com Pietro M. Bardi: possibilitar um processo de modernização autônomo e original. Pode-se dizer que a sua formação não garante seu título de especialista

Fig.18 Escada proposta por Lina para o Solar do Unhão. Desenho baseado no sistema de encaixe dos carros de boi. na atuação na área da memória, no entanto, sua visão atual de história produz o senso crítico necessário para contribuir com estas ações.

Deve-se considerar também que esta noção, muitas vezes diretamente ligada à Lina, tem precedentes já apontados aqui. A proposta de Giedion no momento da retomada das reuniões dos arquitetos modernos no segundo pósguerra dialoga abertamente com esta definição.

O método adotado por Giedion vai muito além da história convencional presa à noção de estilo e se alinha às mudanças metodológicas da historiografia, conforme indicado: "[...] la moderna concepción de la história como conjunto de historias: la construcción, desde el presente, de narraciones a partir de una selección de hechos considerados determinantes del passado."147 Giedion, portanto, desenvolve seu raciocínio através das condições espaciais do lugar e a partir da retomada do passado como compreensão do presente. $O$ antigo só tem sentido se garantida sua coexistência no instante presente. Estas questões traçadas no segundo pós-guerra mostram que a convivência entre 0 antigo e 0 novo é enriquecida por meio da compreensão dos ensaios de Giedion e sua forma de entendimento figurada pelo estudo das mudanças da sensibilidade ou das categorias visuais. $O$ método adotado neste momento por Giedion é similar ao processo usado por Alois Riegl na história da arte. ${ }^{148} \mathrm{Ao}$ analisar os conceitos

\footnotetext{
146 BARDI, Lina Bo. Cinco..., op.cit.

147 SOLÀ-MORALES, Ignasi. Siegfried..., op.cit, p. 219. (grifo nosso)

148 Riegl, teórico e historiador da arte, acredita que a percepção espacial é o verdadeiro conhecimento da produção da humanidade. Morales estabelece um ponto de contato entre Giedion e Riegl através dos princípios abordados como, por exemplo, a retomada do passado como compreensão do presente para 0 entendimento dos problemas colocados pela contemporaneidade. Esta base teórica totalmente presente na discussão do VIII CIAM revela a lúcida proposição do método riegeliano disseminado por Giedion. SOLÀ-MORALES, Ignasi. Siegfred..., idem., p.222.
} 
básicos que determinam a obra de Giedion, Ignasi de Solà-Morales ${ }^{149}$ mostra que seu processo metodológico é muito mais amplo que a história convencional baseada na noção puramente estilística (linear). A moderna concepção da historiografia remete à construção desde o presente de narrações a partir de uma seleção de feitos consideráveis determinantes do passado. $O$ autor revela que na mesma época em que Giedion escrevia Espaço, Tempo e Arquitetura ${ }^{150}$, Fernand Braudel introduzia a noção de coexistência dos tempos (longos, curtos ou individuais) no entendimento de um mesmo acontecimento ${ }^{151}$. Deste modo, não faz sentido entender a arquitetura como sucessões estilísticas, mas sim como um elemento de expressão constitutivo da construção de uma determinada situação cultural. Haveria, portanto, a necessidade de compreendê-la sob suas condições espaciais.

As tendências discursivas ocorridas no VIII CIAM são verdadeiros reflexos desta aproximação. Estabelece-se um ponto de contato entre Giedion e Riegl através dos princípios abordados, como o valor e o significado do monumento como parte integrante do "Coração da cidade", a capacidade de empregar nas discussões urbanas a noção aberta e progressiva das mudanças históricas, a inversão do foco para a perspectiva de quem percebe o objeto, e ainda, a retomada do passado como compreensão do presente para 0 entendimento dos problemas colocados pela contemporaneidade. Esta base teórica totalmente presente na discussão do VIII CIAM revela a lúcida proposição do método riegeliano disseminado por Giedion.

\footnotetext{
149 Idem.

150 Cf. a edição original: GIEDION, Siegfried. Space, Time and Architecture, the growth of a new tradition. Cambridge: Harvard University Press, 1941.

151 SOLÀ-MORALES, Ignasi. Op.cit., p.219.
} 
o diálogo com o brasil

\section{o contexto das intervenções no patrimônio urbano histórico no}

brasil (1930 -1970)

A partir da trajetória pessoal da arquiteta Lina é possível estabelecer relações com a problemática central do trabalho, que diz respeito à relação entre 0 antigo e 0 novo em intervenções urbanas em locais considerados representativos da memória. No curso cronológico de sua formação e experiência profissional, destacam-se como ponto importante para esta discussão as considerações relativas a sua estada em Salvador (de 1958 a 1964) 152. Como é observado no texto, a direção do MAMB, a restauração do Solar do Unhão bem como sua administração revelam na prática o modo como a arquiteta procede no enfrentamento dos temas aqui expostos.

Assim, colocadas estas questões introdutórias sobre a problemática enfrentada nos anos propedêuticos e após a trajetória profissional da arquiteta, julga-se importante analisar o contexto brasileiro sobre o tema, procurando aproximações e divergências com os procedimentos adotados pela arquiteta em obras que tomam a preexistência como premissa projetual e seus desdobramentos no âmbito da preservação. É importante retomar as questões levantadas sobre a abordagem brasileira e construir o plano destas questões sob 0 mote das intervenções em locais de valor patrimonial. 0 foco volta-se principalmente para estes espaços de representação coletiva através de intervenções urbanas, freqüentemente nos centro antigos das cidades. Para tanto, vale retroceder algumas décadas a partir da chegada da arquiteta no Brasil a fim de entender que os problemas das intervenções em locais considerados de valor patrimonial aparecem como questão principalmente através do nosso patrimônio urbano histórico. Neste sentido, cabe aqui ilustrar alguns fatos que colocam em pauta o procedimento metodológico no trato com a cidade existente, o que revela outros aspectos da relação entre o antigo e o novo em nossa trajetória. Desta forma, a postura adotada pelo Serviço do Patrimônio

\footnotetext{
152 PEREIRA, Juliano Aparecido. Op.cit.
} 
Histórico e Artístico Nacional (Sphan) em relação à intervenção em áreas e conjuntos pode ser reveladora destas questões. Esta retrospectiva tem como objetivo traçar um quadro comparativo ao final (no que se refere ao modo de intervir na cidade, de se relacionar com o existente, bem como entender as definições de nossas categorias culturais). Com isso, é possivel entender como Lina se aproxima ou se distancia dos princípios dos agentes diretos nestes tipos de intervenção. Ou melhor, é possível entender porque em alguns momentos Lina é convocada para tal tarefa e em outros é rechaçada.

Vale lembrar que as importações de parâmetros e paradigmas ocorrem sistematicamente nos campos disciplinares, evidenciando muitas contradições na inserção interpretada dessas idéias numa realidade totalmente distinta e, portanto, é necessário entender como estas questões circulam no Brasil. Acredita-se que este panorama seja fundamental para avaliar com mais profundidade o momento em que são realizados os dois projetos urbanos aqui estudados (Brasil, década de 1980).

Também há que se ter em mente que a ampliação da preservação de conjuntos históricos e os debates acerca deste problema serão um tema discutido de forma sistemática depois da década de 1960, não só no Brasil, mas também em outros países. No entanto, cabe colocar aqui alguns precedentes (quase experimentais) ocorridos no Brasil antes desta data. Acredita-se que a intervenção mais significa seja Ouro Preto e esta experiência acaba mostrando alguns caminhos construídos no tratamento entre 0 antigo e o novo.

Sobre as intervenções urbanas promovidas pelo Sphan, de um modo geral, observa-se que o que confere à cidade o exercício propositivo de lidar com o novo e a preexistência se alicerça em parâmetros distintos e muitas vezes contraditórios. Ora o monumento escolhido é destacado, "exposto em destaque, limpado do contexto construído a sua volta à maneira dos CIAM, como nos Arcos da Lapa; ora escondido nas suas imperfeições pelas novas construções que o rodeiam, como na Igreja da Boa Morte, ambos no Rio de Janeiro."153

Ao que tudo indica, o discurso dos "modernistas na repartição"154 em relação à dinâmica entre passado, presente e futuro está vinculado à idéia de

153 PESSOA, José (org.). Lucio Costa: documentos de trabalho. Rio de Janeiro: IPHAN, 1999, p.8. 154 Título do livro CAVALCANTI, Lauro. Modernistas na Repartição. Rio de Janeiro: UFRJ; IPHAN, 2000. 
"invenção"; ou seja, o retorno pretérito significa entender os elementos disponíveis para a invenção do novo - o que se torna quase intrínseco ao próprio ato de projetar. Lucio Costa recorre amiúde ao distanciamento da oposição binária entre o antigo e o novo freqüente na nossa cultura, declarandose muitas vezes "revolucionário-conservador". Ou seja, enquanto retórica, existe uma aproximação entre os funcionários do Sphan e Lina no trabalho de atualizar o passado - o que é verificável principalmente na postura crítica do arquiteto frente à tradição. Mas, no balanço geral prático das intervenções em conjuntos urbanos, a regra não é tão clara como no discurso, a não ser pela tamanha liberdade e quantidade de soluções. A maior certeza é a de que na atuação do Sphan quase sempre o motor da preservação é o critério estético-estilístico. Ou seja, tomando-se a preexistência como tema comparativo entre a arquiteta e os funcionários da preservação, percebe-se que aqui no Brasil esta palavra está ligada muito mais ao seu aspecto (abstrato) estético. A ação "caso a caso" defendida por Lucio Costa e que poderia constituir analogias com a defesa do exame crítico no processo de seleção das obras a serem preservadas (defendido por Lina) parece ser deixada de lado em algumas atuações nas áreas urbanas. A visão particularizada poderia também aflorar 0 valor históricodocumental do objeto, promovendo uma análise da preexistência mais completa que apenas a análise estética. $O$ que acontece na maior parte dos casos é que as ações apenas respondem a uma normativa, fato que acaba generalizando a característica plural do próprio objeto "cidade"; consequentemente, deixa-se de lado a ação "caso a caso" defendida por Lucio Costa. Resulta que o caráter documental, visto como momento de reconhecimento dos objetos como parte de uma construção social, não é levado em consideração na prática. Portanto, 0 resultado também é aquele mesmo à luz de uma idealização da nação e de um distanciamento das condições reais daquele bem. Mesmo com as implicações esperadas sobre as medidas de ampliação do objeto na década de 1960, praticamente não se muda a maneira de intervir. Não só o tratamento da arquitetura antiga faz parte deste discurso mas também a inserção de edifícios novos em tecidos antigos. Apesar de algumas exceções, o que prevalece na prática geral é a restauração segundo um critério estilístico motivado por uma preservação à luz da busca da situação original da obra. 


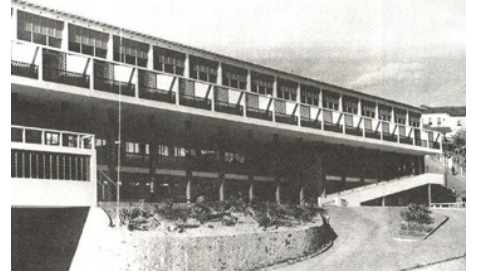

Fig.19 Grande Hotel de Ouro Preto de Oscar Niemeyer.
Segundo Lucio Costa, a compatibilidade entre arquitetura de vários períodos ou mesmo entre o antigo e o novo é possível desde que seja "boa arquitetura"155. Entende-se por "boa arquitetura" aquela que está diretamente vinculada à honestidade material e dos processos que envolvem uma determinada época e lugar. Aquela que não demonstra interesse em escamotear a forma em virtude estética, mas sim que responda os anseios racionais da estrutura e da função. Visa a manutenção estética como imagem idealizada, ou seja, corrobora diretamente com a convivência entre 0 antigo e o novo através dos "sistemas abstratos reguladores de conduta sobre os conteúdos tradicionais de cultura"156. Esta questão fica evidente no papel de advogado de defesa que Lucio Costa assume em relação ao projeto moderno do hotel inserido na "cidade monumento" de Ouro Preto, elaborado por Oscar Niemeyer.

"Rodrigo,

$\mathrm{Na}$ qualidade de arquiteto incumbido pelos CIAM de organizar o grupo do Rio e na de técnico especialista encarregado pelo SPHAN de estudar a nossa arquitetura antiga, devo informar você, com referência à construção em Ouro Preto do hotel projetado pelo O.N.S. [Oscar Niemeyer Soares], o seguinte: Sei, por experiência própria, que a reprodução do estilo das casas de Ouro Preto só é possível, hoje em dia, à custa de muito artifício. Admitindo-se que o caso especial dessa cidade justificasse, excepcionalmente, a adoção de tais processos, teríamos, depois de concluída a obra, ou uma imitação perfeita, e o turista desprevenido correria o risco de, à primeira vista, tomar por um dos principais monumentos da cidade uma contrafação, ou então, fracassada tentativa, teríamos um arremedo 'neocolonial' sem nada de comum com 0 verdadeiro espírito das velhas construções.

Ora, o projeto do O.N.S. tem pelo menos duas coisas em comum com elas: beleza e verdade. Composto de maneira clara, direta, sem compromisso, resolve com uma técnica atualíssima e da melhor forma possível, um problema atual, como os construtores de Ouro Preto resolveram da melhor maneira então possível, os seus próprios problemas. De excepcional pureza de linhas, e de muito equilíbrio plástico, é, na verdade, uma obra de arte e, como tal, não deverá estranhar a vizinhança de outras obras de arte, embora diferentes, porque a boa arquitetura de um determinado período vai sempre bem com a de qualquer período anterior - o que não combina com coisa nenhuma é a falta de arquitetura"157.

Neste exemplo há também uma idéia de controle da cidade. Observa-se que Lucio Costa não acredita que a cidade tratada poderia apresentar um

\footnotetext{
${ }^{155}$ Carta de Lucio Costa para Rodrigo Melo Franco de Andrade. MOTTA, Lia. A Sphan em Ouro Preto: uma história de conceitos e critérios. In: Revista do Patrimônio Histórico Artístico e Nacional, n.22, pp.108-122, 1987.

156 LEITE, Rogério. Op.cit., p.38. Conforme Rogério, a sociedade secularizada reduz 0 alcance da identidade através de um sistema normativo, ou seja, um sistema abstrato de identidade como a idéia de nação e cultura nacional.

157 Transcrição da carta de Lucio Costa para Rodrigo de Melo Franco. MOTTA, Lia. Op.cit.
} 
crescimento relevante, o qual resultaria numa modificação da paisagem conhecida, nem mesmo que as novas construções fossem grosseiramente imitar essa postura inovadora. 0 contraste entre antigo e novo permitido em sua fala tem um limite estabelecido quantitativo (somado ao pressuposto da qualidade da nova arquitetura). 0 processo de crescimento da cidade é visto como tarefa totalmente controlada pelo Sphan, pois acreditava-se que o tratamento das lacunas encontradas no tecido antigo seria uma questão estética pontual.

O tema da qualidade tem medidas abstratas e conduz a uma indefinição ou falta de objetividade dos parâmetros de inserção do novo em ambientes antigos. A convivência entre 0 antigo e 0 novo através do contraste e das diferenças inicialmente proposta por Lucio Costa seria uma forma de preservação dos centros históricos se não houvesse tanta indefinição no critério qualidade, que, por sua vez, responde a esta possibilidade. "Daria margem a um processo natural de continuidade da produção arquitetônica de boa qualidade e ao atendimento das novas necessidades, resguardando a produção preexistente." 158 A proposição de Lucio Costa quanto a esta continuidade da produção arquitetônica brasileira tinha nos princípios construtivos o principal eixo de aproximação entre arquitetura colonial e moderna. No entanto, não foram estas as premissas que guiaram as intervenções em centros históricos nem na própria criação dos edifícios isolados em determinadas lacunas do tecido urbano. A posição de Lucio Costa sobre a criação do novo nas lacunas das cidades existentes acaba se conformando, na prática do nosso serviço de tutela, pelo viés mais conservador da proposição: na simplificação dos traços formais coloniais para a construção de novos edifícios nos preenchimentos de lacunas, aproximando a expressão formal por semelhança. Ou seja, tomando a arquitetura colonial como partido, simplifica-se seu desenho a ponto de se chegar a um modelo próximo dos fundamentos modernos. 0 que não se concebe, então, é que a cidade pode crescer e que esse exercício - visto na origem como solução paliativa para as lacunas do ambiente - poderia multiplicarse. Ouro Preto, seguindo o exemplo colocado anteriormente, revela o número assustador de 3000 novas edificações que seguem essas condições ("imitativas") até a década de 1980. Pode-se dizer que a aproximação da

${ }^{158}$ MOTTA, Lia. Op.cit, p.111. 

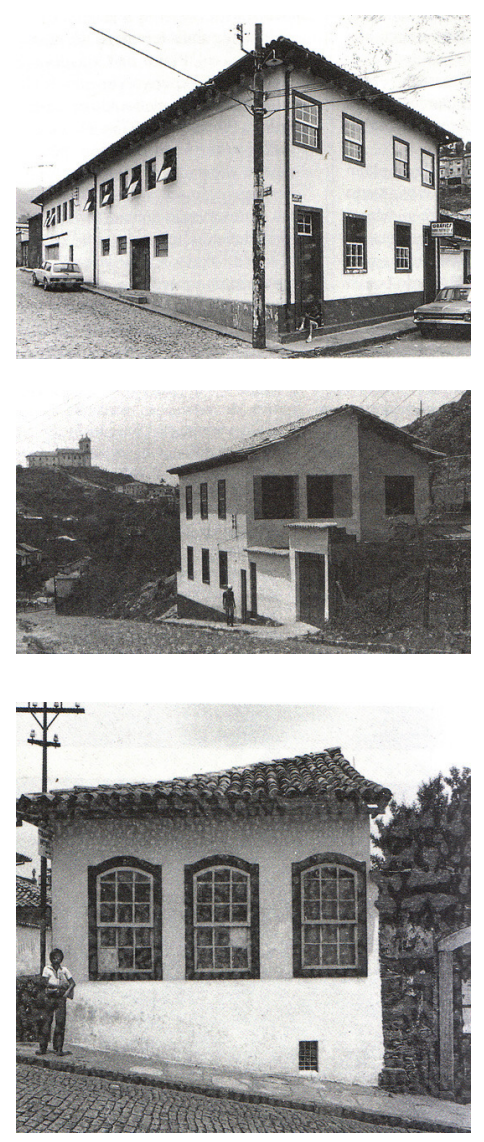

Fig.20 Aplicação das normas formais restritas às fachadas principais.

Fig.21 A obrigação do "estilo patrimônio" resulta numa arquitetura híbrida e dificulta a identificação da natureza do documento histórico.

Fig.22 Revestimentos e elementos impostos pela norma às novas edificações. arquitetura nova e antiga se opera de maneira bem distinta se comparada aos procedimentos de Lucio Costa.

Com o passar do tempo, o exercício de fiscalização "um a um" torna-se impossivel: os casos individuais analisados exaustivamente pela secretaria ganham corpo, impedindo a fiscalização mais direta. A solução para tal ampliação, no caso de Ouro Preto, é mais um momento de abstração da discussão, pois a resposta vem na normatização com a exigência do uso de elementos estruturais em madeira, como folhas em rótulas, guilhotinas ou beirais de cachorro - inclusive em áreas periféricas novas. 159 O que confere preocupação primeira para a continuidade da imagem estética da cidade é traduzido na norma sobre a fachada principal. Ou seja, a identidade é paulatinamente controlada por estes sistemas abstratos de controle, como critérios e normas sobre os elementos estilísticos. A fachada principal consiste no elemento basilar para a aprovação do projeto, abrindo caminho para o uso exacerbado da solução de simplificação dos traços coloniais e constituindo espécies de verdadeiros cenários falsos por meio dessa arquitetura comprometida com o "estilo patrimônio"160. A fachada principal é o elemento que sustenta a prova desse êxito colonial, mesmo que as modificações em fachadas secundárias sejam violentas ou as modificações das plantas não apresentem nenhuma relação com espaço externo. A normatização referente às características formais (gabaritos, etc) pertence ao universo abstrato do monumento, que é desvinculado das características ambientais importantes para sua salvaguarda e também adquire um alheamento com as pessoas que usam esse espaço. Os próprios fatores ambientais preconizados na valorização da paisagem a se preservar em áreas urbanas patrimônio (como o limite de propriedade ou a topografia) são desconsiderados na norma de sua preservação. Assim, essa norma garante apenas a preservação da individualidade e excepcionalidade do monumento existente e não facilita de nenhuma forma a integração do novo edifício com o conjunto. Enfim, a noção de correlação entre patrimônio e lugar passa por esta chancela da criação de uma identidade no sentido de relíquia ou da idéia de símbolo de uma nação ${ }^{161}$.

\footnotetext{
159 Idem, p.112.

160 Expressão freqüentemente usada pelos moradores dessas cidades.

161 Cf. Rogério Proença Leite, a correlação entre lugar e patrimônio num primeiro momento reticente ao projeto de criação de um Estado forte e único, melhor dizendo, da nação, "transita
} 


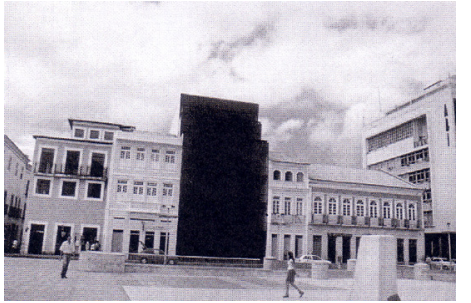

Fig.23 Inserção da nova arquitetura no tecido antigo. 0 contraste não garante a qualidade. Salvador, Praça da Sé.
Enquanto procedimento, esta forma de ver o objeto acaba conformando a idéia de monumento no seu sentido folclórico e exótico.

Nota-se que a ampliação do objeto de preservação - do objeto isolado ao conjunto - representa uma experimentação metodológica solucionada primeiramente sob aspectos abstratos e genéricos como qualidade, e num segundo momento através de categorias referentes às normas. Tudo indica que a cidade existente também é colocada sob seu aspecto mais abstrato da discussão (linguagem arquitetônica), não configurando uma ação que indague sobre sua complexidade. Conforme indica Geraldo Gomes da Silva,

"[...] convém lembrar que a grande maioria dos funcionários públicos arquitetos, a quem competia julgar os novos projetos de inserção em conjuntos antigos, era constituída de arquitetos modernistas. 0 que significa dizer que as janelas rasgadas horizontais, fachadas inteiras de vidro, pilotis e terraços jardim eram elementos de arquitetura perfeitamente aceitáveis para edifícios novos em conjuntos antigos. Tratava-se, portanto, também de garantir a emergência do Modernismo, até mesmo quando se tratava de obediência cega a uma receita que poderia induzir à banalidade". ${ }^{162}$

A norma empregada pelos funcionários do Sphan em prol do passado torna-se flexível ou se solidariza com o presente quando as soluções de intervenção garantem a própria linguagem moderna. No entanto, não há o que indique que o uso desses elementos possa garantir a qualidade da "boa arquitetura". Na maioria dos casos, ao contrário, esta resposta acaba sendo depreciativa do ambiente, pois, mesmo como linguagem nova, não se utiliza a complexidade que pressupõe a análise do meio. Muitos autores chegam a afirmar que o procedimento mais apropriado seria a atenção mais acentuada quanto aos aspectos morfológicos e ambientais. Soma-se à preocupação com o meio a forma como isto é operado em sua complexidade, como é de fato objetivo da dissertação. 0 que se sabe é que a inserção do novo ou do diferente não determina a qualidade daquele ambiente. ${ }^{163}$

Apesar das mudanças no âmbito conceitual a partir da década de 1960, o que se pode afirmar é que o método adotado pelos profissionais na origem do Sphan descrito até aqui teve êxito absoluto. A qualidade fundamental desses

dessa formulação mais abrangente para a concepção mais localizada da tradição, voltada para a adequação do patrimônio às demandas do mercado e ao processo de gentrification". LEITE, Rogério Proença. Op.cit., p.28.

162 SILVA, Geraldo Gomes. Intervenções em sítios históricos. Revista AU, agosto, 1996, p.81.

$163 \mathrm{Idem}$. Neste artigo, o autor apresenta uma série de exemplos sobre a inserção do novo edifício em ambientes antigos que faz apologia aos princípios modernos, mas que não garante a qualidade ambiental. 
conjuntos enquanto portadores de componentes que Ihes dão vida é razão depreciada por quase toda a trajetória desse serviço. A cartilha sempre igual do método adotado e a conseqüente "cidade-cenário" resultante acaba tornando-se ao longo do tempo "natural", principalmente para leigos no assunto. É assumido então que edifícios com aspecto vetusto têm um processo a ser seguido, e, portanto, os critérios, os métodos de restauração, assim como o resultado 'limpo' ou cenográfico, são conseqüências esperadas. Não dizem respeito a ninguém, se não ao interesse já estratificado do próprio serviço encarregado da preservação. A sedimentação da cidade antiga, assim como todo o processo prático evidenciado aqui, acaba favorecendo um tipo de memória distante das feições que realmente lhe dão sentido, pois prevalece o valor onde o passado é melhor que o presente. A proteção torna-se utopia, ou seja, idealização do passado urbano onde "as violências de toda a natureza são excluídas." 164 Encontra-se aqui um paradoxo: a luta pela defesa do patrimônio que tem como objetivo fazer prevalecer nossas particularidades, contra a "ação destrutiva à mundialização, ideológica e econômica" assim como à "homogeneização dos comportamentos, uniformização das cidades", reveste-se absolutamente de um outro princípio universal. Os objetos de atenção acabam parecendo todos iguais. 165 Retomando, tornam-se álibis da gestão urbana e de ações urbanísticas, com a "imensa vantagem de parecerem... apolíticas."166

O sucesso dessa política cultural se dá também devido ao modo eficiente com que o discurso de defesa das identidades entra no campo do planejamento urbano e no processo de urbanização. 0 discurso vitorioso e até mesmo de resistência perante a imposição econômica ou os interesses especulativos, na verdade, é em si um eficiente álibi de concordância entre as partes usado nas alocuções de intervenção urbana. Daí a principal razão da chamada "inflação patrimonial". ${ }^{167}$ Para Márcia Sant'Anna, a própria ampliação do objeto não é apenas um caminho natural, mas está vinculado ao processo de preenchimento estratégico de poder. Ou seja, "o conceito de "área urbanapatrimônio' 'evolui' ou 'se transforma' muito mais em função dos objetivos

164 MONNET, Jérôme. O álibi do patrimônio: crise da cidade, gestão urbana e nostalgia do passado. In: Revista do Patrimônio Histórico e artístico nacional, n.24, pp.220-228, 1996,.

165 Idem.

166 Idem, p.226.

167 Françoise Choay usa o termo "síndrome patrimonial". CHOAY, Françoise. A Alegoria..., op.cit., p.247. 
estratégicos que os resultados de uma evolução da percepção ou do processo das disciplinas que informam a preservação". ${ }^{168}$ Há então uma norma efetuada pelo dispositivo que preside a sua própria constituição. Os elementos discursivos e não-discursivos dessa norma podem ser apreendidos, isto é, tornados inteligíveis, pelo estudo de certos focos de saber, localizados nas operações de seleção, salvaguarda e conservação dessas áreas num dado momento histórico. Assim, Márcia Sant'Anna identifica pelo menos três momentos dessa apropriação do discurso preservacionista como estratégia de poder: de 1937 a 1945, na própria constituição do patrimônio histórico e de identidade nacional; na década de 1970, quando o patrimônio é visto como um fator de desenvolvimento regional; na década de 1980, momento em que o patrimônio assume-se como instrumento de política urbana. A condição de álibi das ações especulativas que a questão patrimonial adquire vai de encontro com os anseios de Lina, bem como coloca em questão o objetivo cultural destas ações.

No geral a política federal restringe-se ao instrumento do tombamento como meio legítimo de intervenção, o que já leva ao distanciamento da proposta de conhecimento real de nossas bases culturais. ${ }^{169} \mathrm{O}$ tombamento, além de criar problemas sobre os limites do direito de propriedade privada, acaba tratando apenas uma parte do problema da representação, principalmente nesta primeira fase. A predominância dos monumentos excepcionais é proveniente do anseio de preservação de uma elite intelectual e da concordância com esses anseios pela permanência de poder das instituições dominantes. É possível antever a distância entre as vozes "intelectuais" e aquelas "representadas". Os símbolos de representatividade - abstratos ao olhar da sociedade - são totalmente distantes do que se preconiza sobre o caráter da memória, pois promovem uma nação pasteurizada, única e homogênea. A proteção serve para promover cada vez mais o distanciamento do acesso público, uma vez que está longe de qualquer tipo de pluralidade e discordância. Em resumo, nossa legislação assim como os critérios de seleção em sua origem estão em concordância direta com 0 momento político autoritário e talvez isto explique a indisposição democrática

168 SANT'ANNA, Marcia. Da cidade-monumento à cidade-documento. A trajetória da norma de preservação de áreas urbanas (1937-1990). (Dissertação de Mestrado. Faculdade de Arquitetura e Urbanismo - UFBA) Salvador, 1995, p.17.

169 O próprio instrumento (tombamento) chega ao cúmulo de ser confundido pela sociedade como política de preservação. Cf. CASTRO, Sonia Rabello de. O estado da preservação de bens culturais: o tombamento. Rio de Janeiro: Renovar, 1991, p. 69. 
ainda hoje. Isto fica evidente na (re)elaboração do projeto de lei escrito por Mario de Andrade. Conforme indica Sergio Miceli "a 'generosidade etnográfica' da proposta andradiana revelou-se descompassada das circunstâncias daquele momento, ao passo que a entronização do barroco firmou-se como a pedra de toque da política preservacionista"170. Promovendo uma continuidade com os moldes da legislação de países "civilizados", Rodrigo de Melo Franco de Andrade elabora o Decreto-lei n. 25/1937, base legal instituída pelo Sphan, a qual conforma as ações da instituição até os dias de hoje. Esta (re)elaboração uniformiza a proposta de Mario de Andrade com o intuito de limpar nosso passado de conflitos ou contrates, assim como coaduna com uma imagem cristalizada, vinculada com as nações civilizadas, principalmente a européia. A norma estabelecida então é uma asserção do mapeamento da atividade do Sphan como predomínio do tom oficial e excepcional dos monumentos selecionados para a proteção. Esse quadro de dominação de uma elite intelectual revela o predomínio temporal, regional e tipológico de bens protegidos pelo órgão oficial. ${ }^{171}$ Segundo Silvana Rubino, o objetivo etnográfico da proposta andradiana, que poderia romper além dos 500 anos de "descoberta" e independência civilizatória, foi surpreendido pelo fascínio barroco. Afirma: "O melhor do passado do Sphan não traz à luz conflitos ou contrastes. Ao contrário estabelece uma continuidade, ainda que na direção de um tempo que já passou."172 Esta é evidentemente a imagem que ainda vigora no âmbito da sociedade, tanto ao que concerne à atividade do órgão de preservação (sua visão de preservação, passado, etc), como à sua própria inflexibilidade. Esta rigidez refere-se, sobretudo, ao estado de isolamento garantido por certa autonomia política e principalmente à vinculação do Sphan a um conhecimento cada vez mais especializado.

O primeiro sintoma diagnosticado é a noção geral deturpada de patrimônio difundida, quase sempre associada à imagem congelada do passado - o que tem conseqüências concretas no modo de agir sobre estes objetos. É essa imagem que ratifica

170 MICELI, Sergio. Refrigério da cultura oficial. In: Revista do Patrimônio Histórico Artístico Nacional, n.22, 1987, p.44.

171 Conforme RUBINO, Silvana. O mapa do Brasil passado. In: Revista do Patrimônio Histórico e artístico nacional, n.24, pp.97-105, 1996.

172 Idem, p.103. 
"[...] o quanto a preservação é dissociada de suas significações coletivas e como está longe de expressar as experiências sociais. [...] Nesse raciocínio, passado e história parecem virar o 'antigo', o que sobrou do movimento de recriação continuada da cidade - uma concepção de ruptura, de passado como processo fechado aos significados sociais. Na direção oposta há a posição de nostalgia daquele passado, um sentimento de perda que na verdade partilha do mesmo processo que a primeira. Algo que não existe mais, um passado fechado. Tudo pode ser destruído ou tudo pode ser conservado é uma noção de história abstrata. Não é uma forma de conhecimento a qual podemos refletir sobre a experiência social. [...] Isso importa claramente para uma sociedade destituída de cidadania, em seu sentido pleno, se por esta palavra entendermos a formação, informação e participação múltiplas na construção da cultura, da política, de um espaço e de um tempo coletivo.[...] Fazer com que nossa produção incida sobre a questão da cidadania implica fazer passar a história e a política de preservação e construção do passado pelo crivo de sua significação coletiva e plural." 173

Preservam-se testemunhos de uma história oficial, distancia-se 0 sentido de história e memória coletiva, colaborando para assegurar uma memória do poder e desvirtuar os aspectos basilares que estruturam a dialética antigo/novo. Conseqüentemente as posturas de cunho prático são inadequadas, servindo de afirmação para uma configuração equivocada do profissional da restauração, quase sempre ligado à tarefa da mera restrição ou anulando qualquer tipo de criatividade no ato do restauro.

Outro fator relevante é a maneira como a necessidade de integração desses monumentos com a vida contemporânea se expressa. A reutilização desses monumentos promove intervenções que resultam em verdadeiras "cascas" externas com o interior desprovido totalmente de sentido. A questão da preservação patrimonial vem eminentemente do seu valor cultural e por isso 0 fator "uso" não deve preceder sua principal justificativa. A reutilização deve respeitar este postulado, sendo então um dos instrumentos empregados na preservação para a sua perpetuação e não meramente um fim. No entanto, percebe-se que 0 inadequado procedimento interno das intervenções muitas vezes se torna "aceitável" na escala da intervenção urbana. E esta percepção sobre os diferentes níveis e escalas da intervenção é aquela da qual muitas ações são privadas. Como coloca Choay: "Modernizar não é, nesse caso, dar a impressão de novo, mas colocar no corpo dos velhos edifícios um implante regenerador. Dessa simbiose imposta, espera-se que o interesse suscitado pela

173 PAOLI, Maria Célia. Memória, história e cidadania: o direito ao passado. In: CUNHA, Maria Clementina Pereira (org.). Op. cit, p.25. 
obra do presente se reflita na obra antiga, dando origem, assim a uma dialética." 174

Para Lina, o passado tem importância na medida em que é reapropriado no presente - 0 que dialoga diretamente com as proposições atuais sobre a necessidade de se considerar como os objetos tidos como representativos da memória são produzidos e modificados no cotidiano. Esta postura está literalmente alinhada com o estudo da preservação do patrimônio como "práticas sociais". ${ }^{175}$

"[...] é preciso se libertar das "amarras", não jogar fora simplesmente o passado e toda a sua história, o que é preciso é considerar o passado como presente histórico. 0 passado visto como presente histórico, é ainda vivo, é um presente que ajuda a evitar as várias arapucas... Frente ao presente histórico, nossa tarefa é forjar um outro presente, "verdadeiro", e para isso é necessário não um conhecimento profundo de especialista, mas uma capacidade de entender historicamente o passado, saber distinguir o que irá servir para novas situações de hoje que se apresentem a vocês, e tudo isto não se aprende somente nos livros."176 (grifo nosso)

A preocupação com a forma de 0 arquiteto se relacionar com o passado é percorrida na proposta sobre ensino da Teoria da Arquitetura, já mencionado anteriormente. A Teoria da Arquitetura deve ser sugestiva para o arquiteto, um

"[...] estímulo à reflexão, às pesquisas, à convicção de que a arquitetura moderna é, como todas as atividades humanas, o produto da experiência do homem no tempo, e de que não existe fratura entre 0 assim chamado "moderno" e a história, visto ser o "moderno" antes o produto da história mesma, através da qual somente é possivel evitar as repetições de experiências superadas. É a história [...] coisa viva e atual, revivida em seus problemas fundamentais dotados de transmissibilidade e fecundos de ensinamentos, essa história que, como é óbvio, não é aquela dos manuais escolares, monótona e de segunda mão, capaz apenas de sugerir a idéia de que o 'passado' passou e não tem mais validade, e que o mundo começou hoje, atribuindo-se ao homem, assim, a tarefa de refazer sozinho a experiência do 'paraíso perdido'; mas, assim a história que não seja a mera 'História' abstrata e sim a vida concreta e fecunda". ${ }^{177}$ (grifo nosso)

Ou seja, o espaço urbano assim como a memória são construções presentes do homem em sociedade. Em geral, tal relevância apenas se confirma se se reflete na eficácia da atuação dos agentes urbanos, assegurando caução à vocação desses espaços. Isto vem ratificar a afirmação anterior sobre o enfoque

${ }^{174}$ CHOAY, Françoise. A Alegoria..., op. cit. p.217.

175 ARANTES, Antonio Augusto. Paisagens..., op. cit.

176 BARDI, Lina Bo. Uma aula de arquitetura. Revista Projeto, São Paulo, n.142, jan-fev, 1992. Sobre o tema da história e o passado em Lina há inúmeras publicações, dentre elas: OLIVEIRA, Olivia Fernandes. Quarto..., op. cit.

177 BARDI, Lina Bo. Contribuição..., op. cit., p.6. 
não direcionado apenas aos aspectos formais resultantes da intervenção na cidade, mas também aos processos de atualização da sociedade - 0 que alguns autores, como Bernard Lepetit, ${ }^{178}$ chamam também de "prática social".

"As variações culturais, os processos de imitação social, a raridade dos momentos de ruptura que fazem dos usos da cidade, sempre um misto de reprodução de comportamentos e de inovação, complicam desmesuradamente a tarefa. Além do mais, o estudo interno dos usos da cidade comporta um risco semelhante ao que corre a análise interna das formas. Dissociar os estudos sobre a urbanidade e as pesquisas sobre a morfologia urbana acarreta a perda da questão urbana em sua especificidade. A cidade não dissocia: ao contrário, faz convergirem, num mesmo tempo, os fragmentos de espaço e os hábitos vindos de diversos momentos do passado. Ela cruza mudança mais difusa e mais contínua dos comportamentos citadinos com os ritmos mas sincopados da evolução de certas formas produzidas. A complexidade é imensa."179

Alguns autores no Brasil consideram o conhecimento de nossas atuais dinâmicas como fator indispensável para se construírem lugares públicos que afirmam o sentido do "comum" (sem imposições de uma determinada estratificação social). Antonio Augusto Arantes também se utiliza da idéia de "prática social"180 enquanto construção da memória, assim como Rogério Proença Leite fala da necessidade de se considerarem os "contra-usos"181 destes espaços. As idéias de "prática social" e de "contra-usos" aparecem como afirmações sobre a necessidade de complementar tais intervenções com algo além de apenas operações quantitativas. Esse imperativo parece retomar escopos sobre a vocação do espaço a ser considerado e discussões provenientes da necessidade da identificação e do pertencimento. Supor a realidade além de absorver a sucessão de modificações orientadas pela vida

178 LEPETIT, Bernard. Por uma Nova História Urbana. São Paulo: Editora da Universidade de São Paulo, 2001.

179 Idem, p.141.

$180 \mathrm{O}$ autor explica que, enquanto os autores britânicos privilegiam a formação de rituais e símbolos de poder, o seu interesse parte da compreensão dos processos através dos quais estes marcos culturais e símbolos nacionais são produzidos e modificados pelas pessoas comuns, no cotidiano, em especial nas práticas referentes ao espaço urbano. "Interessa-me o estudo da preservação do patrimônio como prática social" e compreender de que modo essa prática participa da formação do espaço público". ARANTES, Antonio Augusto. Paisagens..., op.cit, p.10.

181 Rogério Proença Leite fala das políticas de intervenções ligadas ao regate do patrimônio histórico como forma de substituição direta de seus agentes e usuários, numa forma de "curetagem social" (observação emprestada de Michel de Certeau). "Essa observação de Certeau sugere, à primeira vista, que os bairros enobrecidos parecem perder sua potencialidade como espaço público de dissensão política e equidade de participação." No entanto, ele afirma que "(...) a desapropriação desse sujeito não implica necessariamente um esvaziamento (ou morte) do espaço público, mas uma reordenação da sua lógica interativa, a partir das apropriações ("táticas") do espaço mediante a construção e lugares. As formas de uso situam a problemática dos significados do patrimônio num ponto que, ao meu ver, é central para o atual debate sobre o esvaziamento (ou não) do espaço público em áreas de 'revitalização' do patrimônio." (grifo do autor). LEITE, Rogério Proença. Op.cit., pp.215-216. 
cotidiana é apreciar as motivações de quem usa tais espaços, algo que possibilita também a sua permanência.

\section{a década de 1980 como momento de diálogo}

A oposição entre as categorias culturais, dentre elas o antigo e o novo, desmancha-se no processo de criação em Lina. Como colocado, a ruptura com a visão progressista e linear do tempo advém de uma formação européia, de uma experiência adquirida na atuação profissional, somadas ao enfrentamento do contexto que aqui the é apresentado. A arquiteta aprende e torna intrínseco à sua ação cotidiana aquilo a que o profissional envolvido com a cidade ou com a memória hoje responde de forma específica. Ou seja, o processo de formação aqui resgatado permite entender a cidade em sua complexidade, atribuindo ao espaço um caráter plural e dinâmico. Além disso, o profissional deve trabalhar com juízo crítico na maneira de se intervir. Esta revisão das categorias culturais e a ampliação da ação profissional aparecem nas atuações de preservação do patrimônio histórico em meados da década de 1960 na Europa e na de 1980 no Brasil.

Outro ponto importante é o contexto político em que os dois objetos propostos para estudo (o Centro Histórico de Salvador e a proposta para o Concurso: Vale do Anhangabaú) estão inseridos. Na década de 1980, com o processo de democratização e abertura política, de fato se identifica nas respectivas áreas ligadas à arquitetura e ao urbanismo a ânsia de se discutir 0 espaço público (entendendo-o em seu sentido mais amplo) e sua representatividade. Não é por acaso que neste período o foco volta-se para projetos que envolvem principalmente lugares considerados representativos da coletividade, "corações da cidade". Esta ambiência democrática no Brasil conforma algumas conseqüências, como o favorecimento de propostas de concursos de idéias e a possibilidade de ampliação do debate.

É também neste período que a área da preservação no Brasil conta com a tentativa de mudança nas definições de nossas categorias culturais bem como nos processos de seleção e proteção dos bens. A contribuição de Aloísio Magalhães vem no sentido de re-elaborar as noções de memória e bem cultural e de modificar o objetivo dos discursos oficiais de preservação. Essa orientação, 
bastante diversa da geração anterior que lida praticamente com conceitos da arte e da histórica, passa a ser a de conhecer e referenciar as nossas manifestações existentes e dar possibilidades e apoio para 0 seu desenvolvimento. 0 discurso da preservação das áreas urbanas volta-se para a tentativa de dar seguimento a esse processo de ampliação e democratização, trazendo para a pauta das discussões a percepção da "comunidade" em detrimento da valorização turística, usada como mote para angariar a preservação no período anterior.

O ano de 1967 representa uma mudança de rumos em nossa prática de preservação. Com a aposentadoria de Rodrigo Melo Franco de Andrade e a posse de Renato Soeiro, pode-se dizer que o Sphan prepara-se para traçar caminhos da modernização do aparelho estatal. Após um período de depressão econômica, o governo militar inicia um processo de estabilização no país, o que tem resultados entre 1967 e 1973. O tom anunciativo dessa política é o desenvolvimento, sendo a indústria a maior beneficiária (principalmente a automobilística). Nesses termos, o patrimônio perde a importância no discurso político, principalmente em relação a seu aspecto cultural, e a política de urbanização segue modelos encontrados no urbanismo moderno. A preleção em defesa do patrimônio modifica-se conforme 0 interesse primeiro desse contexto. A Comissão Nacional de Política Urbana (CNPU) contribui para a modificação do discurso técnico: "Esta procurou aliar a preservação dos recursos naturais e do patrimônio cultural ao desenvolvimento, e reverter o fenômeno de concentração urbana no Sudeste pelo incremento da base econômica das metrópoles do Nordeste e o fortalecimento dos núcleos de médio porte."182 Inicia-se então um período de reflexão sobre esta nova forma de encarar o patrimônio com a ajuda direta da UNESCO. Paralelamente, a Norma de Quito (1967), assim como toda a orientação dos países subdesenvolvidos, coloca em destaque o valor econômico do patrimônio cultural. O turismo surge então nos países subdesenvolvidos como a atividade econômica mais adequada nessa conciliação patrimônio-economia.

No Brasil, encontros são promovidos para rediscutir o assunto. Nessa altura, com o regime militar, o campo cultural passa a ter uma importância no espaço da manipulação ideológica: "a cultura é posta a serviço de um projeto de hegemonia, no qual assumem postos estratégicos a integração e a memória

182 SANT'ANNA, Marcia. Da cidade-monumento..., op.cit., p.158. 
nacional."183 Dessa maneira o regime constrói um aparato de produção cultural, com destaque para o Programa Integrado de Reconstrução das Cidades Históricas (PCH), o qual tem como objetivo principal a reconstrução das cidades históricas do nordeste.

O foco para o nordeste tem a promoção do desenvolvimento econômico através do turismo como diretriz, o que congrega a afirmação ideológica da nacionalidade com o desenvolvimento.

Na década de 1970, são promovidos os encontros dos governadores que geram primeiramente o Compromisso de Brasília (1970) e depois o Compromisso de Salvador (1972). Ambos os documentos, apesar de aparentemente serem vistos como um processo de abertura na discussão da preservação e da descentralização do poder do órgão, na verdade, estão de acordo com as linhas gerais da política pretendida pelo governo autoritário. Seus objetivos não são tanto os méritos intrínsecos da questão cultural (a não ser pela manipulação ideológica), mas têm como foco a política e a economia.

Com a criação do $\mathrm{PCH}$ e de sua estrutura administrativa em conjunto com a Secretaria do Planejamento como política ligada ao patrimônio de conjuntos, pode-se identificar a origem da relação patrimônio e planejamento no Brasil. Apesar da desconfiança quanto aos critérios que não os culturais, essa inter-relação poderia criar reflexões sobre a real representatividade dos objetos preservados dentro da sociedade, bem como sobre a atuação do Sphan: seus critérios, suas definições, suas normas e ações. Apesar disso, nota-se que 0 $\mathrm{PCH}$ assim como o Sphan atuam de forma independente e conformam estruturas autônomas de trabalho. As atividades deste programa acabam encontrando bastante dificuldade, desde problemas financeiros ao próprio entendimento técnico. Além disso, nota-se que a defesa econômica e política como objetivo da preservação não sustenta a lógica dos princípios dessa atividade.

"Os técnicos da SEPLAN que participavam do grupo coordenador do PCH em Brasília desde o início estavam conscientes de que o problema da conservação das cidades históricas não seria resolvido apenas mediante o incremento da atividade turística. A expansão do programa foi a oportunidade de alteração

183 Idem, p.159. Maria Londres Fonseca afirma que "O caráter marcadamente cultural na atuação do Sphan nas três primeiras décadas revela-se inadequada ao novo modelo de desenvolvimento". FONSECA, Maria Cecília Londres. O patrimônio em processo. Rio de Janeiro: UFRJ/Iphan, 2005, p.141. 
dessa abordagem, ensejando um processo de reavaliação das suas diretrizes, que se completa em 1979."'184

Esta tendência revela-se problemática conforme as medidas tomadas vinculam "os investimentos governamentais às exigências do consumo massificado e aos interesses empresariais do turismo, o que, por sua vez, reforçou a tendência de preservarem os suportes físicos de uma história reconstruída de maneira linear e em tom glorificante."185 É dessa forma que, próximo aos dias de hoje, Antonio Augusto Arantes mostra que a questão da preservação implica uma série de medidas jurídico-administrativas,econômicas e arquitetônicas, mas que, além disso, implica também num conhecimento ainda mais profundo sobre o processo de re-elaboração que se dá no plano sociológico, ou seja, sobre a recepção social de tais monumentos no cotidiano das comunidades com as quais convivem diretamente. Só assim a condição presente pode abarcar e transgredir tais edificações de 'pedra e cal'.

Com a posse de Aloísio Magalhães na direção do órgão de preservação em 1979, os objetivos do Sphan entram em acordo com a discussão do grupo do qual este fazia parte, o Centro Nacional de Referencia Cultural (CNRC). Em um curto período, verifica-se uma transformação nas argumentações sobre 0 intuito de se preservar assim como nos principais objetivos da política pública de preservação.

O CNRC é criado em 1970, no âmbito da Universidade de Brasília, por alguns professores, dentre eles Aloísio Magalhães, com objetivos bem distintos daqueles vinculados à política desenvolvimentista no âmbito do discurso da preservação e proteção dos bens. 0 interesse vem da preocupação com a compreensão da cultura brasileira no contexto contemporâneo. 0 caráter experimental ligado ao ensino e pesquisa acaba convertendo-se em um ensaio para as formas mais adequadas de funcionamento de um órgão envolvido com os interesses culturais nacionais mais amplos (não nacionalistas ${ }^{186}$ ). Procura-se então 0 produto cultural segundo sua dinâmica cotidiana, viva, com todas as divergências e pluralidades. Acredita-se que com essa visão mais ampla sobre a

184 SANT'ANNA, Marcia. Da cidade-monumento..., op.cit., p.169.

185 ARANTES, Antonio Augusto. Documentos históricos, documentos da cultura. Revista do Patrimônio Histórico Artístico Nacional, n.22, 1987, p.52.

186 Usando-se da definição usada por Lina, "Nacionais são os valores reais de um País, ao passo que nacionalistas são as atitudes políticas que visam impor certas particularidades de um país com todos os meios, às vezes com a violência."(grifo do autor). BARDI, Lina Bo. Tempos..., op.cit. p.17. 
cultura, somada ao conhecimento do estado real do cotidiano, seja possivel entender 0 potencial criativo das atividades, abrindo passagem para o seu crescimento e ampliação da sua representatividade. Dar possibilidades para o desenvolvimento do nosso saber-fazer tradicional e não se 'adequar à' ou assimilar modelos prontos e sem referência cultural. Com isso, cria-se uma visão não romântica da nossa cultura, de modo que não que ela não seja endossada por um olhar folclorista ou com objetivos paternalistas. "O objetivo, nesse caso, passava a ser o de conhecer, referenciar e compreender essas manifestações, visando preservar sua memória e fornecer elementos para o apoio a seu desenvolvimento"187 Esta mudança vem da percepção da inadequação do modelo de desenvolvimento sócio-econômico adotado então pelo país. "(...) será que a nação brasileira pretende desenvolver-se no sentido de se tornar uma nação rica, uma nação forte, poderosa, porém uma nação sem caráter?"188 0 desenvolvimento desejado pressupõe benefícios materiais apenas, sem nenhum tipo de crescimento interno como herança identitária - no sentido de valorizar as nossas próprias riquezas e possibilidades. É lançada uma nova visão sobre patrimônio cultural, onde a relação estabelecida envolve uma noção distinta de lugar. Essa nova visão alinha-se com a postura de entender os modos de se fazer, os processos sociais que envolvem a constituição da vocação do lugar, o que é tema presente nas discussões sobre a cidade existente do pós-guerra. Esta nova visão, além de antecipar a discussão sobre os significados do patrimônio imaterial levada a cabo hoje nos debates sobre preservação, consegue também dialogar com o que é preconizado por Lina em suas intervenções - e é aqui que começa a fazer sentido esta retrospectiva. No quadro contextual apresentado percebe-se a inadequação das instituições culturais do Estado para lidar com tamanha mudança. Para Aloísio Magalhães, a política cultural significa conhecer estas possibilidades, viajar, dialogar e apoiar a descentralização.

Há pelo menos três conceitos fundamentais que explicam a matriz cultural então planejada e implementada: a noção de continuidade, de bens culturais e de cultura jovem. Para assegurar a identidade e autonomia no contexto internacional, presume-se a continuidade com o passado não como

\footnotetext{
187 Idem, p.148.

188 MAGALHÃES, Aloísio. Op.cit, p.14.
} 


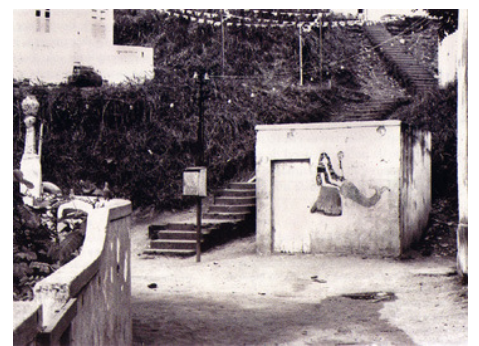

Fig.24 Terreiro da Casa Branca, Salvador. Um dos primeiros testemunhos da cultura afrobrasileira tombado (1982). aporte nostálgico, mas como comprometimento, ou seja, conhecimento para uma tomada de posição.

"A ênfase na continuidade - feita de mudanças, alterações e eventualmente de rupturas - não se confunde com a defesa do passado ou do elitismo cultural. [...] 'não tem sentido a memória apenas para guardar o passado. [...] A tarefa da preservação do patrimônio cultural brasileiro, ao invés de ser uma tarefa de cuidar do passado é essencialmente uma tarefa de refletir sobre o futuro. "189

0 progresso nesta noção não tem sentido de mudança e sim o de conscientização, o que faz uma ponte direta com o que preconiza originalmente Mario de Andrade na estruturação do serviço de patrimônio e com o que Lina promove nas ações dos museus. 0 conceito de "novo" que aqui se estabelece está na realimentação do passado, atualizando-o, pela continuidade do processo: "Uma cultura é avaliada no tempo e se insere no processo histórico não só pela diversidade dos elementos que a constituem, ou pela qualidade de representações que dela emergem, mas sobretudo por sua continuidade". ${ }^{190} \mathrm{~A}$ grande diferença, se compararmos com a noção empregada na criação do Sphan é que aqui não se pretende impor nenhum tipo de sincretismo ou apagar as discordâncias existentes em nossa base cultural. A concepção de cultura trabalhada aqui tende a superar as oposições, embora mantendo as relações de tensão existentes entre os distintos pólos, ou seja, nesta perspectiva, pode-se dizer que a dissonância tende a prevalecer, ao menos enquanto projeto.

A noção de bem cultural esclarece melhor os objetivos pretendidos se comparados aos aspectos que pressupõe a noção de patrimônio histórico e artístico. Essa abordagem representa dizer que se modifica toda a noção de monumento, passado e identidade. A noção de bem cultural também dialoga com a proposta andradiana nessa ampliação. Aloísio Magalhães dá algumas pistas deste alargamento do conceito:

"[...] o conceito de bem cultural no Brasil continua restrito aos bens imóveis, contendo ou não valor criativo próprio, impregnados de valor histórico (essencialmente voltados para o passado), ou aos bens de criação individual espontâneo, obras que constituem o nosso acervo artístico (música, literatura, cinema, artes plásticas, arquitetura e teatro) quase sempre de apreciação elitista [...] Permeando essas duas categorias existe vasta gama de bens procedentes sobretudo do fazer popular - que por estarem inseridos na dinâmica viva do cotidiano não são considerados como bens culturais nem utilizados na formulação das políticas econômicas e tecnológica. No entanto, é

189 Idem, p. 17.

190 Idem, p. 44. 
a partir deles que se afere o potencial, se reconhece a vocação e se descobre os valores mais autênticos de uma nacionalidade."191

A questão da cultura popular é de fato algo a se considerar. É apreciável que a formação de Aloísio Magalhães na área do design acabe lançando uma tangente sobre o trabalho de Lina, o que de fato corrobora para a 'atualidade' das ações promovidas pela arquiteta nesse período. 0 artesanato torna-se objeto de investigação do CNRC no sentido de se entender não apenas o produto cultural (entendido em sua materialidade, resultado), mas, antes, todo o processo do 'fazer', ou seja, as 'práticas sociais' envolvidas. A lição sobre a empreitada brasileira no enfrentamento da indústria tem um cunho cultural amplo que passa pelo crivo das nossas necessidades de mudança metodológica. № sentido ortodoxo do termo artesanato, Aloísio Magalhães chega a retomar as questões colocadas por Lina quando esta se depara com a dificuldade de identificar claramente a existência de artesanato brasileiro. Assim como Lina, o CNRC confirma a existência da disponibilidade para "o fazer", para a criação de objetos. Neste sentido, acredita-se que seja imprescindível no processo de valorização dos bens culturais o acompanhamento e o incentivo desta condição para que se possa dar possibilidade ao desenvolvimento em harmonia e com autonomia com o nosso "pré-design" (e não "artesanato"). 192

O quinto capítulo do livro "E Triunfo?: A questão dos bens culturais no Brasil.", de autoria de Aloísio Magalhães, é dedicado à preservação e revitalização das cidades históricas. Aqui é importante a utilização do instrumento de preservação do tombamento paralelamente à pesquisa da vocação do uso contemporâneo. Apesar da ênfase dada ao turismo, Aloísio Magalhães afirma que 0 Sphan deve garantir em primeiro lugar a estabilidade dos bens culturais, dando-lhe a continuidade do sentido cultural implícito. É preciso reinseri-los na vida da comunidade, tornando-os novamente importantes e participantes do cotidiano. ${ }^{193} \mathrm{~A}$ cultura popular, assim como a "prática social" envolvida, torna-se meio para a criação do novo, através da noção de continuidade.

A ampliação da questão patrimonial com enfoque na noção de bem cultural contribui para a democratização da cultura, mas, no entanto, coloca-se

\footnotetext{
191 Idem, p.19

192 Idem, p.173.

193 Idem, p. 185.
} 
em pauta a sua efetivação. Como dar conta da diversidade cultural e social? Como compatibilizar a abrangência sugerida? Como programa de governo, a proposta tem como crivo a sistematização e a normatização, o que a torna problemática na prática. Ainda que o conceito ampliado tenha sido incluído na Constituição Federal de 1988, no artigo 126, o instrumento jurídico realmente utilizado pelo órgão com esse interesse não é adequado para proteger categorias imateriais (como festas, modos de saber-fazer, etc). 0 tombamento tem características ligadas à prática de se lidar apenas com coisas palpáveis, móveis ou imóveis e acaba por tornar-se algo bastante abstrato quando tratado em termos imateriais.

"É fato que o texto constitucional não restringiu a proteção do patrimônio ao tombamento, porém, ainda não se desenvolveu na sociedade brasileira formas alternativas que possam dar conta da salvaguarda dessa tipologia específica de bens que são os de natureza imaterial, assim como há problemas com a preservação dos bens móveis - sejam acervos artísticos, sejam iconográficos ou ainda textuais. E mesmo dentre os exemplares do "patrimônio cultural consagrado" - os bens de pedra e cal - não foi essa ampliação conceitual menos problemática: os técnicos do Patrimônio resistiram em incorporar entre os bens arrolados nos livros de tombo da instituição aqueles que escapassem aos cânones artístico e histórico até então praticados para que se pudesse incluir tipologias, estilos e períodos históricos mais recentes." 194

Nesse sentido, cabe avançar de forma um tanto mais aprofundada sobre a questão da impossibilidade do tombamento como instrumento legítimo de preservação de áreas urbanas patrimônio.

Nesse período, a maioria dos processos abertos diz respeito às cidades e centros históricos (demonstrando a influência das recomendações da Carta de Veneza), além das chamadas "ampliações" dos tombamentos. Em muitos casos, o critério de tombamento desvia-se da questão artística para o processo histórico, sendo muitas cidades escritas no Livro de Tombo Arqueológico, Etnográfico e Paisagístico. Também nessa época evidencia-se um incremento significativo da participação da sociedade nos pedidos de tombamento. No entanto, na prática, as operações de conservação ou as próprias restaurações encaixam-se no âmbito da política de preservação de origem: com a seleção dos elementos significativos para evidenciar ainda mais nosso passado colonial. 0 que confere aos conjuntos a estratégia é a "facilitação das atividades turísticas e a restauração de alguns monumentos destacados que promovessem a

\footnotetext{
194 CUNHA, Claudia dos Reis e. Op.cit., p.67.
} 
conservação das áreas adjacentes por 'contágio', conforme teoria defendida por Michel Parent." 195 Apesar da tentativa da combinação de ações ligadas à salvaguarda de áreas urbanas-patrimônio ${ }^{196}$, com a elaboração de planos diretores, na prática, as principais ações de preservação ocorrem no domínio do tombamento federal. Essa observação sobre a vitória de um instrumento como modelo vem afirmar positivamente a hipótese de que "a manutenção da lei federal desempenhou, entretanto, um importante papel na estratégia de sobrevivência do Iphan após a criação do $\mathrm{PCH}$, quando a instituição se viu ameaçada pela perda de exclusividade no trato da questão do patrimônio."197Como explica Márcia Sant'Anna:

"Apesar do $\mathrm{PCH}$, do CNRC e da abertura da questão da preservação para os estados e municípios, nos anos 70 o IPHAN permaneceu uma instituição fechada e dominada por arquitetos de formação modernista. 0 contato com os urbanistas e planejadores da SEPLAN não mudou o modo de pensar do quadro técnico da instituição. Ao contrário, esses outros é que foram catequizados. De fato, não houve interferência real do IPHAN neste período. 0 esquema montado, inclusive no que diz respeito aos cursos de especialização, reforçou sua posição de principal instância detentora e produtora de conhecimento sobre patrimônio. A intervenção só ocorreu com a fusão do IPHAN, CNRC e PCH no sistema SPHAN/Pró-Memória, e com a entrada na nova instituição de profissionais ligados à área de história, sociologia, antropologia e economia, que trazem novos conteúdos para a prática institucional. Mesmo assim, aferrada à sua lei e às suas tradições, a instituição criada por Rodrigo M. F. de Andrade mais uma vez sobrevive." ${ }^{198}$

Como delimitação temporal da pesquisa, considera-se importante avaliar a década de 1980, período em que a conjuntura política abre portas para uma reavaliação das posturas dos arquitetos e urbanistas. Cabe também colocar em pauta a responsabilidade política do arquiteto e urbanista na articulação de projetos com formas que garantam a representatividade através da participação popular no debate como espaço público democrático. É assim que o "retorno à cidade" é entregue à busca desses meios que 0 arquiteto e urbanista dispõem. Na realidade, na década de 1980, o discurso da preservação das áreas urbanas volta-se para a tentativa do processo de ampliação e democratização dessa esfera, trazendo para a pauta das discussões a percepção da "comunidade" em detrimento da valorização turística. Este discurso permanece após a morte de

\footnotetext{
195 SANT'ANNA, Marcia. Da cidade-monumento..., op.cit., p.178.

196 Termo usado por Márcia Santana que tem o mesmo significado de "patrimônio histórico urbano".

197 Idem, p.183.

198 Idem, p. 187.
} 
Aloísio Magalhães, em 1981, quando o PCH começa a montar uma proposta de preservação dos centros históricos no quadro do desenvolvimento urbano e da política habitacional. O caso de Olinda exemplifica a entrada da questão da habitação na pauta da política de preservação. Em 1985, com os bons resultados de Olinda ${ }^{199}$, cria-se o Programa de Recuperação e Revitalização de Núcleos Históricos (PRRNH) que não chega verdadeiramente a ser implantado, funcionando apenas até 1986.

Alguns problemas devem ser identificados nessa tentativa de mudança da visão sobre a proteção de bens patrimoniais. A modificação dos conceitos que efetivam a qualidade de salvaguarda enquanto representantes de um modo de ver a cultura, a ampliação dos objetos e a abertura pretendida às múltiplas vozes da sociedade brasileira são fatos evidenciados. Alguns embates ainda são enfrentados ou mesmo surgem outros ainda mais dificeis de serem resolvidos. 0 critério de seleção ainda é um campo de lutas entre sociedade e órgão de preservação. Apesar da tímida, mas presente, participação dos cidadãos nos pedidos de tombamento, ainda é o órgão oficial que apresenta a palavra final e que, representando as "vozes do saber", define a atuação. A ampliação do objeto também se defronta com 0 instrumento legítimo de salvaguarda, 0 tombamento. A descentralização política ainda encontra vícios em relação à preferência federal como efetivo nível de respeitabilidade.

O que se observa, portanto, é que não se faz a passagem entre a mudança estabelecida no conceito e a intervenção em si. A orientação metodológica nas ações pragmáticas acaba estreitamente vinculada à idéia de preservação de "relíquias", tanto nos monumentos isolados como em conjuntos urbanos. A questão se complica ainda mais no tratamento dessas áreas urbanas-patrimônio:

"Em suma, a revisão crítica da prática institucional de preservação não foi capaz de constituir uma metodologia de análise urbana destinada à orientação

\footnotetext{
199 Colocadas as premissas conceituais e ainda a necessidade da participação como condição sine qua non para a salvaguarda e ação de proteção em conjuntos ou áreas a serem preservadas, registram-se aqui as anotações empíricas dessa experiência piloto. Vera Bosi relata os problemas ainda renitentes. 0 que se percebe é que tal tipo de trabalho, que teoricamente ampliaria a noção de patrimônio, torna-se romântico e até mesmo retorna ao seu estado 'heróico' caso não haja também mudanças na própria estrutura dos órgãos deliberativos da preservação. Em resumo, essa atuação revela-se problemática em alguns momentos, principalmente no que concerne à burocratização da estrutura administrativa e à defasagem temporal de um trabalho interdisciplinar compatível com os recursos orçamentários. Ou seja, a descentralização do poder de nada serve se não implicar em mudanças não apenas deliberativas, mas também relativas ao processo metodológico e executivo.
} 
de intervenções adequada aos seus propósitos de abandono do privilégio da questão estética e de registro do processo de produção do espaço. [...] a principal dificuldade no estabelecimento de normas aplicáveis e coerentes em sua intervenção decorre do fato de que não se tem ou não se montou uma metodologia adequada para a seleção das características do espaço que se quer preservar, em contextos de significativa diversidade tipológica. Também não se sabe quais as relações que as construções novas ou reconstruções deviam manter ou não com essas características. Intui-se que a manutenção do parcelamento e o controle dos volumes é o essencial, mas não se abandona definitivamente o controle estético e estilístico. Apesar de algumas vozes discordantes, que chamam corretamente a atenção para o caráter especial e fundamentalmente mutável do elemento urbano enquanto objeto patrimonial, no geral, se continua, mesmo em nome da preservação da diversidade, a repetir o mesmo tipo de regra de intervenção que se adotou tradicionalmente em Ouro Preto."200

Ou seja, no patrimônio urbano histórico conforma-se um problema específico advindo da própria característica de um bem isolado. 0 problema vem da estruturação de uma metodologia adequada que conforme suas múltiplas facetas e não apenas as questões estéticas. 0 resultado visto na maior parte dos casos é a intervenção meramente "fachadística", que uniformiza o espaço urbano, simplificando os traços tipológicos, como é o caso de Ouro Preto. Essa natureza "cenográfica", em concordância com a dinâmica do contexto global, cria um espaço para a fruição efêmera e para a mera contemplação à distância.

"Essas configurações particulares da paisagem tendem a ser seqüestradas de seu contexto físico e social imediato, por intervenções que as estilizam dramaticamente e que - nessa nova roupagem - oferecem-nos para resgate pelo comércio e para o consumo visual [sic] de moradores e visitantes. Reforça essa idéia de fratura e descontinuidade dessas áreas em relação ao contexto urbano 0 fato de estes investimentos imobiliários e urbanísticos não valorizarem 0 entorno imediato desses bens freqüentemente identificados como deteriorados, mas limitarem-se, em geral, a requalificar exclusivamente aqueles pontos que configurem vistas favoráveis da cidade-ícone."201

É recorrente a expulsão compulsória das dinâmicas locais envolvidas, provocando ainda mais essa percepção 'cenográfica', ou pior, sedimentando progressivamente os limites que separam o espaço público das indesejáveis diferenças sociais. Como já foi colocado desde 0 início, a proliferação dessas intervenções urbanas progride desenfreadamente e de maneira praticamente aleatória na transformação da cidade e na substituição das dinâmicas cotidianas do lugar.

200 Idem, p.222.

${ }^{201}$ ARANTES, Antonio Augusto. Paisagens ..., op.cit., p.153. 
"A fragmentação da cidade em paisagens de diferença e desigualdade configura política de espaço que ainda é pouco conhecida na América Latina. Esse relativo desconhecimento compromete a eficácia e adequação das políticas urbanas e culturais às demandas emergentes, tornando-se um empecilho à consolidação das formas de democracias de gestão política."202

Com isso, é possível antever algumas razões da dinâmica atual da atuação e assim evidenciar algumas fontes cabais da nossa produção, tanto em seu aspecto conceitual como no próprio processo prático de atuação. Percebese que as modificações existentes insinuam ainda resultados práticos vinculados à idéia de "patrimônio símbolo da nação", comprometendo toda a ampliação do conceito de cultura, bem como a democratização de seus valores intrínsecos. As diretrizes são praticamente privatizadas pelo próprio órgão de preservação e seus interesses, o que impede mais uma vez a visão plural do campo ${ }^{203}$. As dinâmicas encontradas na atuação constituem, dessa forma, representantes deste interesse maior, o que desvincula a noção de patrimônio como espaço coletivo de representatividade. 0 que resta então é a visão da preservação como apenas um obstáculo e motivo de protesto constante vindo da sociedade. Toda a metodologia condiz com a visão das classes dominantes vinculadas, sobretudo, à questão estética e da imagem internacional midiática. Afirma-se a visão homogeneizada pelos interesses turísticos e econômicos, além da aparente tranqüilidade advinda da percepção de um lugar sem conflitos. Tomando a comparação de Antonio Augusto Arantes como referência, as intervenções em áreas consideradas importantes lugares de representação da memória tornamse próximas de muros de condomínio (aqueles que asseguram a defesa, a harmonia, e escondem a violência e as diferenças encontradas nas cidades).

Tal como exposto aqui, todo o processo necessita de modificações, o que se inicia com a admissão de nossas condições reais e com a redefinição dos elementos que envolvem aquilo que chamamos de bem material. Primeiro, necessita-se incorporar as revisões sobre os conceitos de memória, passado, história e cultura - já tão desenvolvidos e atuais no Brasil. Segundo, entender

\footnotetext{
202 Idem, p.161.

203 "A cidade - seja ao vivo ou nas cores das instituições de comunicação ou mercado - continua sendo lócus e objeto de importantes disputas na incessante estruturação prática e simbólica da cidadania. Mas longe de apresentar-se como aquele mosaico de peças fixas marcadas e previsiveis que a sociologia urbana clássica consagrou, o espaço urbano - mais do que nunca descontínuo e tecnologicamente mediado - é hoje o sítio onde ganham configuração concreta experiências que ao mesmo tempo formam referenciais espaço-temporais flexíveis e identidades em processo de constante reconfiguração."(grifo do autor) Idem, ibidem.
} 
como isto se realiza: desde os instrumentos legais até os processos de atuação. Ao que concerne ao patrimônio urbano histórico, entender primeiramente a característica urbana e quais são os agentes envolvidos. Repensar os conceitos que envolvem a troca interdisciplinar. Rediscutir os instrumentos legais assim como sua efetivação democrática.

Acredita-se que seja possível identificar a característica da convivência entre 0 antigo e 0 novo nas intervenções urbanas ligadas ao patrimônio no Brasil. Usando das palavras de outro autor:

"Nas cidades brasileiras, ainda com maior força, as idéias de progresso e modernidade têm levado a uma sistemática destruição das marcas do passado. A sintomática ausência de preocupação com o problema e a virtual fragilidade dos órgãos públicos de preservação e planejamento urbano têm criado uma situação de extrema gravidade no que diz respeito à necessária convivência entre o 'antigo' e o 'novo'. Se no 'antigo' reside uma parcela importante da memória social e da identidade cultural dos habitantes da cidade, desconsiderar a questão do patrimônio histórico-ambiental urbano é exilar o cidadão, alija-lo de seu próprio meio - fazer da cidade um ambiente hostil e estranho à maioria da população. Como diz o documento publicado pelo SPHAN-PRÓ-MEMÓRIA em 1982, 'do equilíbrio entre o novo e o velho depende 0 equilíbrio cultural de uma cidade, de uma sociedade. $E$ esse equilíbrio garante a continuidade do seu singular'."204

Todo esse arcabouço analítico sobre as mudanças em relação ao conceito de patrimônio, de representatividade e preservação de bens tem como finalidade dar condições para as análises pretendidas no decorrer da dissertação. Acredita-se que seja importante considerar essa experiência como contraponto da trajetória de intervenção em áreas consideradas patrimônio urbano histórico realizada por Lina. Pode-se dizer que a arquiteta trabalha paralelamente ao tom oficial da preservação, no entanto, suas ações acabam complementando as modificações defendidas por Aloísio Magalhães, principalmente no tocante à visão não nostálgica sobre o passado e à condição meritória das "práticas sociais" no processo de criação do novo - ou melhor, no salto de desenvolvimento em relação ao enfrentamento da indústria sem deixar de lado nossas bases culturais reais, não idealizadas.

"O problema é que as demandas empresariais da indústria do turismo não subvertem apenas a lógica da seleção dos bens a ser preservados, evidenciando apenas aqueles potencialmente bons a ser preservados, evidenciando apenas aqueles potencialmente bons para o retorno financeiro. Pelo consumo massificado, reforçam exatamente os aspectos mais

204 MAGALDI, Cássia. O público e o privado: propriedade e interesse cultural. In: CUNHA, Maria Clementina Pereira (org.). Op.cit. 
monumentais desses bens, alienando-os dos seus significados históricos locais, construídos pelas práticas cotidianas daqueles que com eles convivem."205

As ampliações evocadas na década de 1980, como a noção de representatividade e a própria ampliação do objeto, colocam as questões relativas à preexistência como fator primordial do conhecimento na atuação do arquiteto. Estas lições perpassam muitas vezes o plano argumentativo através de meras importações, mas na real condição não é o que se efetiva. Isto fica evidente nas ações sobre intervenções urbanas nesses lugares representativos da memória coletiva, como é o caso do Concurso: Vale do Anhangabaú, por exemplo, onde diversas falas percorrem este tema. É comum profissionais envolvidos nessas intervenções usarem argumentos advindos das discussões colocadas (como a atenção ao contexto, à ampliação da representatividade, às condições ambientais e culturais, etc), mas esquecerem de incorporá-las ao processo, passando então a responsabilidade para uma instituição maior. É por isso que 0 caso da arquiteta Lina vem trazer uma reflexão bastante importante a respeito. Os meios usados pela arquiteta pressupõem as questões que a cidade existente predispõe através do próprio processo projetual, no diálogo entre antigo e novo, permanência e inovação. Portanto, a memória coletiva, a participação, a cultura local são garantidas pelos meios projetuais e não por iniciativas paternalistas ou por normativas pós-intervenção. Esses lugares não precisam ser instituídos como "lugares da memória" porque nesse processo eles o são naturalmente. É um caminho diverso, alheio ao processo de tombamento e que poderia favorecer a permanência das relações estabelecidas naquele lugar sem nenhuma imposição árdua, mas de modo que a garantia do seu valor simbólico se fizesse espontaneamente pela própria consciência da população que a usa.

${ }^{205}$ LEITE, Rogério P. Op.cit., p.60. 
PARTE 2

intervenções urbanas de lina bo bardi: a cidade em sua complexidade 


\section{centro histórico de salvador}

\section{situação e reconhecimento do patrimônio}

Para tratar do objeto empírico proposto, necessário se faz retroceder alguns momentos que marcaram a consolidação da área do centro antigo de Salvador como "patrimônio urbano histórico", bem como avaliar os instrumentos administrativos e políticos utilizados para a sua proteção.

A data de 1927 é considerada um marco na tentativa de proteger e defender as edificações às quais se atribui valor artístico ou histórico em Salvador, no momento em que se cria a Inspetoria Estadual dos Monumentos Nacionais. Essa articulação privada entre Estado, Igreja e sociedade mostra-se conflitante e ineficaz devido aos diferentes interesses, no entanto, a união de forças representa uma tentativa de proteção de algo avaliado como frágil ou propenso ao desaparecimento. Num contexto nacional, a criação destas Inspetorias Estaduais configura-se como resposta do poder público às demandas do meio intelectual, que alertava sobre a "ameaça de perda irreparável dos monumentos de arte colonial"1. Este momento reflete também a preocupação em reverter as transformações ocorridas no final do século XIX e início do século XX com o freqüente processo de modernização das cidades e a destruição, principalmente, da herança colonial.

A segunda metade do século XIX em Salvador, como na maioria das cidades brasileiras, caracteriza-se como um período em que as transformações urbanas são utilizadas como ferramenta político-administrativa com o intuito de modificar as más condições de salubridade, higiene e circulação das cidades coloniais. É nesse contexto que a cidade de Salvador ganha outros traçados em expansões próximas ao centro - e novas tipologias, como os bairros Graça, Vitória e Canela. Também é na direção do "embelezamento" soteropolitano que Salvador se configura como duas distintas cidades: a cidade projetada e símbolo do desenvolvimento e do capital; e a cidade dos excluídos, que ocupam espaços abandonados do centro da cidade bem como pequenas choupanas nas periferias.

\footnotetext{
${ }^{1}$ FONSECA, Maria Cecilia Londres. Op.cit, p.94.
} 
A área conhecida como "Pelourinho" (parte da área de estudo analisada nesta dissertação) fica à margem do processo de modernização neste período, acumulando o excedente da população excluída da produção agrícola em declínio, através do chamariz do baixo aluguel e da proximidade com as áreas de serviço. Apesar das inúmeras tentativas reformistas na década de 1930, como a abertura da Avenida Sete de Setembro, a derrubada da Sé e as incisivas modificações do traçado existente, o Pelourinho ainda se caracteriza como área segregada por suas condições de moradia, pela alta taxa de violência e prostituição e, finalmente, pela deliberada ação repressiva e violenta da polícia. Ainda que o contexto aqui colocado trace um quadro marcadamente social - em relação ao aspecto de degradação que evoca esta área e que mais tarde configura um complexo problema do centro antigo -, o que realmente provoca a reação de proteção é a preocupação em se preservar a herança e o acervo material dos bens culturais presentes no conjunto arquitetônico do centro de Salvador, ou seja, em prol do "patrimônio urbano histórico".

Outros fatos apontam a preocupação com a herança cultural na década de 1930. Antes mesmo da criação do Sphan, durante a Semana do Urbanismo, realizada em Salvador, no ano de 1935, reconhece-se o valor simbólico e a importância patrimonial da cidade no contexto da memória nacional. A reivindicação do reconhecimento federal de Salvador como monumento nacional é uma reação aos iguais direitos concedidos à cidade de Ouro Preto dois anos antes, em 1933. Também a Bahia está presente na exigência perante a federação da criação de mecanismos legais para a proteção dos bens patrimoniais. Segundo Fonseca², em 1930, o deputado baiano José Vanderlei de Araújo Pinho apresenta ao Congresso Nacional uma proposta neste sentido. Em 1937. Salvador consta da Regional do Sphan que inicia o trabalho de tombamento de monumentos isolados fazendo eco à voz da política nacional implantada. $^{3}$

Resultado da Semana do Urbanismo são as medidas de organização das informações sobre a real situação do município para se criar efetivamente

\footnotetext{
2 Idem, pp.95-96.

3 Conforme a Parte 1 desta dissertação. Ver CHAGAS, Maurício de Almeida. Modernismo e tradição: Lina Bo Bardi na Bahia. Dissertação de Mestrado da área de Desenho Urbano apresentada na Faculdade de Arquitetura e Urbanismo da Universidade Ferdaral da Bahia. Salvador, 2002, p.105.
} 
planos e métodos de gestão condizentes com a melhora da qualidade de vida, bem como com a preocupação em se planejar o futuro. Desse modo, a década de 1940 é marcada pelos trabalhos do EPUC (Escritório do Plano Urbanístico da Cidade) $)^{4}$, no sentido de ampliar o conhecimento científico sobre os diversos aspectos que influenciam na proposta urbana, como os fatores físicos, sociais e econômicos. Este olhar mais abrangente procura, através de um trabalho interdisciplinar, abarcar a complexidade da cidade nordestina. 0 resultado mais imediato destes levantamentos e estudos é o Código de Urbanismo de 1948. As propostas que se seguiram nos anos posteriores são consideradas continuidades das idéias desenvolvidas neste período. A Avenida do Contorno, projetada por Diógenes Rebouças ${ }^{5}$, em 1952, localizada na encosta entre Cidade Alta e Cidade Baixa e que faz uma importante ligação da cidade via litoral, é um exemplo significativo da dimensão moderna do sistema de circulação proposto. A abertura de novas possibilidades no sistema viário, segundo uma concepção moderna de soluções técnicas e estéticas, culmina num processo de importante transformação da paisagem urbana. A construção da Avenida do Contorno somada mais tarde ao projeto de recuperação do Solar do Unhão como museu podem ser consideradas ações decorrentes deste processo de transformação da paisagem e, portanto, de afirmação das disputas de poder sobre o espaço urbano.

Este processo de crescimento urbano e de disputas territoriais inicia-se na década de 1950 e amplia-se na década de 1960 com o novo ciclo de industrialização, com a instalação da Petrobrás e os recursos financeiros da Sudene ${ }^{6}$. Apenas como parâmetro referencial, é exatamente neste período de enriquecimento econômico que Lina é convidada para trabalhar em Salvador.

O surto de crescimento da capital baiana acaba encontrando no patrimônio cultural uma barreira para o desenvolvimento.

"Nas décadas de 1950 e 1960 ocorreram grandes mudanças no modelo de desenvolvimento brasileiro, responsáveis pelos impasses com que a política de preservação do Sphan foi confrontada, levando a instituição, e outros setores

\footnotetext{
${ }^{4}$ Criado em 1943 por Mario Leal Ferreira.

5 "Arquiteto vinculado às novas elites de Salvador - conservadoras, mas modernizantes, ligadas à lavoura do cacau ou à recente instalação da Petrobrás - de inconfundivel viés racional funcionalista e, tal qual os demais pioneiros modernistas brasileiros, também funcionário do Sphan local." Cf. CHAGAS, Maurício. Op.cit, p.43.

${ }^{6}$ A Superintendência para Desenvolvimento do Nordeste tinha como objetivo criar investimentos nesta região a fim de acabar com as desigualdades de desenvolvimento e crescimento em relação a outras regiões do país. Foi criada em 1959, no governo de Juscelino Kubitschek.
} 
da administração pública que passaram a se interessar pela questão, a recorrer a novas alternativas de atuação. Neste período, a ideologia do desenvolvimento atrelou o nacionalismo aos valores da modernização [...] As conseqüências para a preservação desse modelo de desenvolvimento repercutiram não apenas no nível simbólico - na medida em que essa ideologia se contrapunha à continuidade e à tradição - como nos níveis econômicos e social - devido ao intenso processo de migração para as capitais e a valorização do solo urbano, desarticulando processos espontâneos de preservação do patrimônio, tanto o edificado como o paisagístico. Na prática do Sphan, surgiram tensões agudas, especialmente na preservação das cidades históricas e dos centros históricos das grandes cidades."

Nesta disputa entre "desenvolvimentistas" e "protecionistas", sem a perspectiva de diálogo entre as partes, a situação é resolvida, sobretudo, através da implantação de leis ligadas à tutela. Em 1958, o Sphan tomba parte do centro antigo de Salvador. Ainda que as prerrogativas usadas alegassem preservar parte de uma herança para as gerações futuras (como ato cultural), este é um momento em que o patrimônio é usado como estratégia política, ou seja, como fator de desenvolvimento regional.

Conforme 0 estudo desenvolvido na Parte 1 desta dissertação, em geral, a política de tutela dos conjuntos históricos segue a mesma direção excludente dos monumentos isolados enquanto representatividade. São ações que privilegiam a noção de "relíquia muda" - que não diz respeito a ninguém, a não ser ao próprio Estado e à elite cultural designada para a tarefa da tutela dos bens. Os processos de restauração, principalmente quando dizem respeito aos conjuntos ou problemas advindos dos tecidos urbanos, espelham a vontade e 0 desejo dos funcionários "modernos da repartição" em atribuir-lhes a possibilidade de concretizar a genealogia da arquitetura criada por eles (barroco-moderno). A restauração privilegia principalmente 0 aspecto estilístico e centraliza a busca dos vestígios coloniais "originais". Vale retomar também que a arquitetura moderna é aceita dentro do contexto do tecido antigo desde que seja "boa arquitetura". Neste momento, não podemos esquecer que aqueles arquitetos que idealizam o Sphan são os mesmos envolvidos com a construção da cidadecapital Brasília - símbolo da identidade nacional. Salvador não foge à regra. É neste período que o professor Maurício Chagas aponta as inúmeras execuções de edifícios modernos no entorno imediato do centro antigo. "Essas ações contribuíram para a destruição da volumetria da cidade antiga e romperam com a

${ }^{7}$ FONSECA, Maria L. Op. cit., p. 141. 
configuração do traçado da trama viária original, tal qual já ocorrera nas primeiras décadas do século, no processo de modernização da área central." 8

Em 1967 é criada a Fundação do Instituto do Patrimônio Histórico, Artístico e Cultural da Bahia, vinculado ao governo estadual, e que em 1980 transforma-se no IPAC (Instituto do Patrimônio Artístico e Cultural). Apesar da descentralização pretendida, o trabalho de restauração ou manutenção de bens patrimoniais ainda é tarefa desenvolvida pelo Sphan local, espelhada nas ações da direção nacional. O IPAC, ao contrário, orienta o trabalho muito mais para a ação social do que para a prática de restauração ou manutenção de edifícios.

Nesta mesma data, em 1967, ocorre a primeira mudança administrativa no Sphan nacional. A forte crise financeira bem como as avançadas críticas sobre a atuação vigente até então promovem a transformação sistemática, visando agregar outros valores em suas ações que não apenas 0 valor cultural. É aqui que se reconhece a importância do suporte turístico para a sobrevivência do patrimônio. 0 processo de descentralização é mais uma estratégia políticoadministrativa para reverter a crise do papel do Sphan.

Neste novo período são abandonadas as idéias do EPUC, principalmente a visão radiocêntrica e a conseqüente noção de centro único. Novos eixos viários são criados acompanhando o crescimento de outras centralidades, como o Centro Administrativo, o Shopping Iguatemi e a Rodoviária, por exemplo. Estas novas frentes de expansão criam enormes excedentes territoriais à espera da nova ocupação. "Estas intervenções vão alterar completamente o padrão de circulação de veículos e pessoas, provocando um esvaziamento das funções do antigo centro". Os Planos implantados a partir da década de 1960 podem ser considerados incentivadores da preservação do antigo centro de Salvador na medida que são vistos como estratégia política de atrativo financeiro, principalmente com a crescente indústria turística no país. ${ }^{10}$ Os patrimônios histórico, paisagístico e cultural são usados

\footnotetext{
${ }^{8}$ CHAGAS, Maurício. Op. cit., p.106.

9 WIPLI, Mônica. Intervenções urbanas em Centros Históricos. Estudo de Caso: cidade de Salvador. Dissertação de Mestrado apresentada na Faculdade de Arquitetura e Urbanismo da USP. São Paulo, 2001, p.96.

${ }^{10}$ As transformações urbanas têm como frente dois planos urbanos: na década de 1960, o Plano do CIA (Centro Industrial de Aratu) e posteriormente o PLANDURB (Plano de Desenvolvimento Urbano de Salvador)
} 
como álibi positivo para a implantação destes planos. ${ }^{11} \mathrm{O}$ deslocamento das antigas funções centrais para áreas periféricas acaba agravando a degeneração física da área antiga, que permanece segregada e isolada durante longo período. Neste centro antigo o modo de ocupação é extremamente precário: os edifícios ou são ocupados numa densidade ingente, em condições subumanas, sem infraestrutura básica e salubridade, ou então, são apenas ruínas. Apesar do estado de abandono e degradação, o Pelourinho, na década de 1970, é freqüentado por alguns grupos que o viam como ponto de encontro e lugar representativo da cultura negra.

Com o intuito de transformar a área do Pelourinho, algumas iniciativas no âmbito local, estadual ou nacional são concomitantemente promovidas após a década de 1970.

No momento do encadeamento da crise do petróleo e com o abalo financeiro decorrente, inicia-se a ampliação da noção do patrimônio e a liberação às iniciativas particulares de preservação de edifícios. Aloísio Magalhães, dirigente do serviço patrimonial neste período, dá início a modificação dos procedimentos até então utilizados pelo Sphan. Na Bahia o reflexo desta ação é o Inventário de Proteção do Acervo Cultural, de 1975, promovido pela esfera estadual do governo. A abordagem deste trabalho segue o exemplo do modo de atuação do CNRC, principalmente na pesquisa sobre o artesanato, os processos envolvidos na feitura dos objetos, os modos de fazer, as condições sociais, ambientais e econômicas. A mesma esfera estadual, dentro dos novos parâmetros estabelecidos pelo Sphan, desenvolve o projeto Mapeamento dos Monumentos Negros da Bahia, o qual mais tarde possibilita o tombamento do Terreiro da Casa Branca, referência e símbolo das crenças afro-brasileiras. Este tombamento é de grande importância, uma vez que foge à regra conhecida e delineada pela "fase heróica" do Sphan, a qual promovia, enquanto representatividade, a exclusão de grande parte dos brasileiros no processo de seleção dos bens tombados - pela escolha sempre ligada às características estéticas monumentais, barrocas e brancas. A imagem da cultura brasileira promovida pelas instituições oficiais, além de restrita, é vista apenas como monumento oficial ou relíquias mortas. 0 tombamento do terreiro significava corrigir as desigualdades, valorizar uma cultural plural, ainda viva e inserida na

${ }^{11}$ MONNET, Jérôme. Op. cit., p.220. 
prática social cotidiana. No caso da Casa Branca, o tombamento foi conduzido por grupos vinculados aos movimentos negros e apoiado por instituições culturais, acadêmicas e outros grupos sociais.

O conjunto urbanístico do Centro de Salvador, tombado pelo Sphan e considerado Patrimônio da Humanidade, é então valorizado enquanto objeto de atenção política a partir da década de 1970. Duas intervenções são consideradas decorrentes desta valorização: a de 1986, idealizada pela prefeitura de Salvador, na administração de Mario Kertész; e a proposta de 1992, promovida pelo Governo Estadual durante a gestão de Antônio Carlos Magalhães.

Em 1980, o IPAC inicia a prática de intervenção em imóveis isolados no centro histórico com o intuito de se criar equipamentos sociais voltados para a população residente.

Três anos depois, em 1983, o Sphan aprova a re-ratificação do processo de tombamento do centro histórico, o qual inclui a ampliação do tombamento já existente na área ${ }^{12}$. Estas ampliações são significativas, uma vez que refletem a influência da Carta de Veneza e a idéia de que estas áreas não têm apenas um valor "documental", mas também são testemunhos de uma particular evolução da organização social local.

Após o tombamento federal, o centro histórico de Salvador é declarado Patrimônio Cultural da Humanidade pela UNESCO, em 1985. Percebe-se que no nível local estas discussões ganham contínua presença e organização após este reconhecimento. Neste mesmo ano, dois eventos realizados na cidade de Salvador abrem caminho para uma efetiva ação de recuperação do centro histórico: a exposição "Viver na Cidade" sobre as condições urbanas no mundo realizada no Teatro Castro Alves; e o Seminário sobre Renovação Urbana no Brasil, que contou com o apoio da Fundação Alemã para o Desenvolvimento Internacional. A partir de então, a colaboração entre estudantes, profissionais da área e moradores é direcionada para a elaboração da proposta de um Projeto Piloto com o objetivo de demonstrar os vários aspectos da problemática do bairro, através de um caso individual no coração do Pelourinho. ${ }^{13} 0$ projeto tem

\footnotetext{
12 Número do processo 1093-T-83.

13 Segundo o folheto de divulgação, o projeto foi desenvolvido na Escola Superior de Artes de Berlim em cooperação com um grupo composto por sociólogos, juristas e arquitetos. O IPAC
} 


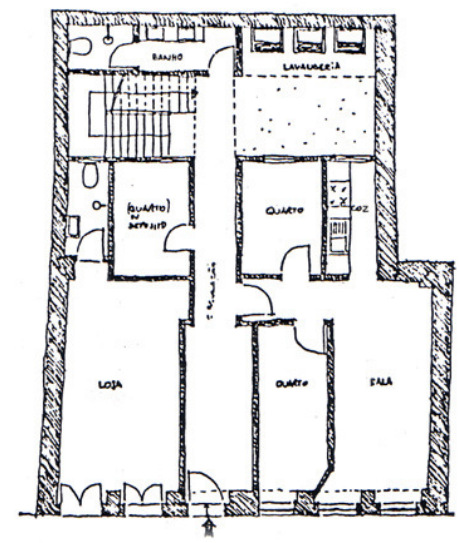

Fig. 25 Planta do andar térreo da proposta de habitação para um casarão no Centro Histórico de Salvador. (sem escala) dois focos importantes de atuação que são tanto a recuperação técnica do centro histórico, quanto a criação, para além do processo de restauro dos edifícios e da malha urbana, de condições necessárias de moradia para a população existente no local - na maior parte de baixa renda. As condições encontradas neste momento são praticamente idênticas àquelas que Lina se depara um ano depois:

"As construções do Centro Histórico de Salvador são prédios de dois ou três andares, outrora habitados por fazendeiros e suas famílias. Datam do período entre o final dos séculos XVII e XIX e hoje em dia $30 \%$ são ruínas ou semiruínas. Seu estado de deterioração se acelera, a ameaça de desabamento é grande e ameaça fazer vítimas. Os prédios ainda são propriedade de famílias dos antigos moradores e 10\% deles pertencem à Igreja. [...] A população do bairro é composta por famílias de baixa renda, geralmente numerosas, e por indivíduos que trabalham no local (serviço público, artesanato, construção civil, serviços, etc.), bem como por grupos marginalizados. Estes últimos, apesar de minoritários, são os responsáveis pela má reputação do bairro.

No coração do Pelourinho moram 2000 pessoas. E uma vez que apenas 50\% dos prédios são habitáveis (os outros são ruínas, sedes de instituições, lojas e oficinas), não é de se admirar que em alguns deles tenha uma densidade de ocupação de uma pessoa por m²."14

Através da compra de uma ruína de $100 \mathrm{~m}^{2}$ do centro e a escolha de três famílias residentes no local, o trabalho desenvolveu-se a partir das resoluções jurídicas e da proposta de arquitetura que deveria seguir com a colaboração dos próprios moradores por meio da mão-de-obra em mutirões. As três famílias foram selecionadas segundo alguns critérios bem claros: 1. tempo de moradia no local; 2. renda familiar; 3. composição familiar; necessidade e situação atual de moradia da família - situação precária ou provisória; 4. relação de vizinhança para que haja continuidade no funcionamento administrativo em cooperação. Percebe-se a preocupação com a participação dos futuros moradores na discussão projetual, principalmente na decisão do programa do projeto. Apesar da pouca repercussão deste trabalho, pode-se considerá-lo como um início da proposta da prefeitura para esta área um ano mais tarde.

A implantação do Programa de Recuperação e Revitalização de Núcleos Históricos acontece em Salvador em 1986, dando continuidade ao objetivo colocado na ocasião do Plano Piloto idealizado pela esfera municipal: "criar condições técnicas, econômicas, financeiras e operacionais para a recuperação de habitações antigas [...] e otimizar a utilização, sobretudo pelas

também participou com funcionários do Setor Social. Folheto desenvolvido pelo IPAC, 1985. Encontrado no arquivo do Instituto Lina Bo e P. M. Bardi. ${ }^{14}$ Idem. 
populações de baixa renda, da infra-estrutura existente nessa área."15 Observase que a orientação dos objetivos de preservação amplia-se desde o momento de sua proposição - são visões ligadas aos aspectos existentes no local e sua vocação principalmente habitacional. Com os limites da complexidade do trabalho - pela situação de deterioro técnico e social em que se encontra a área, além dos entraves jurídicos -, a prefeitura local propõe a intervenção em alguns pontos dispersos sobre a área em questão. A idéia é a de que a partir destes pontos se crie uma espécie de exemplo que interfira em seu entorno imediato, criando um tipo de rede de influência. A proposta é espalhar no tecido do centro histórico algumas casas

"[...] onde se fizesse sentir a presença de alguns países aos quais se ligam por laços os mais diversos as origens e o desenvolvimento de nossa cultura nacional e a identidade do povo brasileiro - sobretudo daqueles países cuja participação em nossa história fora permanente e propositadamente ignorada". ${ }^{16}$

Lina entra aqui como personagem quando é chamada pela prefeitura, em 1986, para assumir o projeto de intervenção do Centro Histórico de Salvador. ${ }^{17}$ Colocadas as condições pela prefeitura, principalmente a consideração das dinâmicas locais existentes durante o projeto de recuperação do centro histórico, ficam evidentes os propósitos da aceitação da arquiteta. Algumas intervenções de recuperação dos centros de algumas cidades históricas já eram conhecidas naquele momento como exemplos drásticos da expulsão das dinâmicas cotidianas locais em prol do crescimento imobiliário ou da indústria turística. ${ }^{18}$ Desta forma, a partir das considerações da prefeitura local, é provável que Lina acreditasse na possibilidade de mostrar que seria possivel proporcionar desenvolvimento sem romper com a cultura e a tradição local. Esta idéia de renovação sem rompimento com a cultura existente parece ser um procedimento perseguido constantemente nos trabalhos desenvolvidos em Salvador pela arquiteta - na direção do MAMB, na idealização do MAP e da escola de design no Solar do Unhão. Talvez neste momento Lina visualize a

\footnotetext{
15 Programa Nacional para recuperar Núcleos Históricos implantado em 1973 no âmbito nacional. Patrimônio (Boletim Informativo do IPAC/SEC), Salvador, n.9, jan-mai, 1986, p.3.

${ }^{16}$ AMADO, Jorge. Jorge Amado e o Pelourinho. Revista Projeto, n. 142, jan-fev, 1992, p.46.

17 Silvana Rubino acredita que Lina fora chamada não apenas para a recuperação do centro histórico propriamente dito, mas também da efervescência cultural dos anos anteriores ao golpe de 1964. Lina está diretamente envolvida com o movimento cultural baiano da década de 1960. RUBINO, Silvana. Rotas da..., op.cit, p.104.

18 Veneza pode ser considerada o exemplo mais significativo.
} 
possibilidade de dar continuidade ao trabalho iniciado vinte anos antes e interrompido com o golpe militar em 1964.

É dessa maneira que Lina e sua equipe apresentam a proposta para o Centro Histórico de Salvador, ou seja, adotando uma postura retrospectiva e confiante no amplo compromisso cultural a ser retomado. Assim a arquiteta coloca a perspectiva de restauração a ser adotada frente às condições locais preexistentes:

"Não é um trabalho turístico, feito com intenção de transformar o Pelourinho numa cidade sorvete.(...) não a preservação de arquiteturas importantes (como Minas) mas a preservação da Alma Popular da Cidade."19

Sabe-se da impossibilidade de sustentar apenas edifícios monumentais considerados importantes para a oficialidade sem pensar nas relações de pertencimento e identidade com a comunidade existente naquele lugar. A realidade local, o comércio, a habitação de moradores que se enraizaram naquele lugar são conteúdos importantes, que informam 0 projeto de preservação proposto por Lina e equipe. Sua intenção é preservar, antes de tudo, as próprias relações estabelecidas entre pessoas e lugar - o que novamente aproxima Lina das propostas de preservação enunciadas por Aloísio Magalhães. Numa outra esfera, preservar as relações entre homem e lugar é também uma aproximação com os arquitetos modernos do pós-guerra uma vez que esta geração "pretendia elaborar soluções que dialogassem com os modos de percepção do espaço, com as escalas e com os usos dados às formas existentes, requalificando a própria relação do homem com o espaço."20

\section{momento político e a aproximação de salvador e lina}

Para falar da aproximação de Lina com a cidade de Salvador é importante considerar o momento político e os agentes envolvidos no quadro cultural, tanto em âmbito nacional como regional. Para tanto, a dissertação desenvolvida por Juliano Pereira sobre a atuação de Lina em Salvador fornece elementos importantes que contribuem para a compreensão deste período. ${ }^{21}$

O período que vai de 1945 a 1964 é conhecido como momento

${ }^{19}$ FERRAZ, Marcelo (org.). Op.cit. p.270.

20 BARONE, Ana Cláudia Castilho. Op.cit., p.115. Esta passagem na realidade refere-se ao arquiteto Van Eych.

21 PEREIRA, Juliano. Op.cit, p.50-60. 
demodrático-populista. Numa perspectiva "democrática", os governos de Juscelino Kubitschek, Jânio Quadros e João Goulart são vistos como momentos de possibilidade de transformação da esfera política, social e cultural do país. A busca da modernidade e do desenvolvimento é colocada em pauta: a construção de Brasília proposta pela vanguarda arquitetônica moderna brasileira e 0 combate da desigualdade entre as regiões do país com a constituição da Sudene são exemplos significativos deste momento. As mudanças estruturais no país decorrentes da busca de novas alternativas para o desenvolvimento econômico e cultural são vislumbradas tanto no discurso da direita quanto da esquerda política. Estas mudanças tinham a intenção de romper com as estruturas econômicas e culturais vigente no país e, por isso, contava com uma nova figura política: o povo.

A idéia de "revolução" com a participação do povo tinha como foco principal chegar a uma autonomia econômica e cultural, apesar das distintas formas de abordagens entre a burguesia urbano-industrial e o PCB (Partido Comunista Brasileiro). Neste contexto, a UNE (União Nacional dos Estudantes) estabelece os Centros Populares de Cultura com o intuito de provocar através dos artistas um processo de conscientização do povo para uma efetiva ação de transformação. Esta ação "pedagógica" terá grande impacto no Nordeste no fim da década de 1950 e início da década de 1960. Outras iniciativas em prol do conhecimento da real condição econômico-social-cultural e da busca de novas soluções para melhorar o quadro do Nordeste são promovidas pelo governo federal, como é o caso da Sudene, da Artene ${ }^{22}$ e o CETA (Centro de Estudos e Trabalho Artesanal). As idéias então promovidas possibilitam traçar um paralelo com as questões levantadas por Lina na busca do entendimento da real necessidade e possibilidade do desenvolvimento do país. Algumas categorias também são colocadas em evidência, como a importância do artesanato em oposição ao folclore, o abandono da idéia de memória nacional única, a luta pela ruptura da hierarquia entre o saber erudito e o popular, a valorização da cultura popular como propulsora do desenvolvimento de uma indústria autóctone. Conforme Juliano Pereira, em algumas cartas da época, Lina, durante a direção do MAP no Solar do Unhão, faz referência ao CETA e inclusive solicita apoio da Sudene. Outras propostas alinhadas com a idéia do desenvolvimento cultural

22 Órgão criado em 1961 dedicado à ajuda aos produtores da arte popular local. 


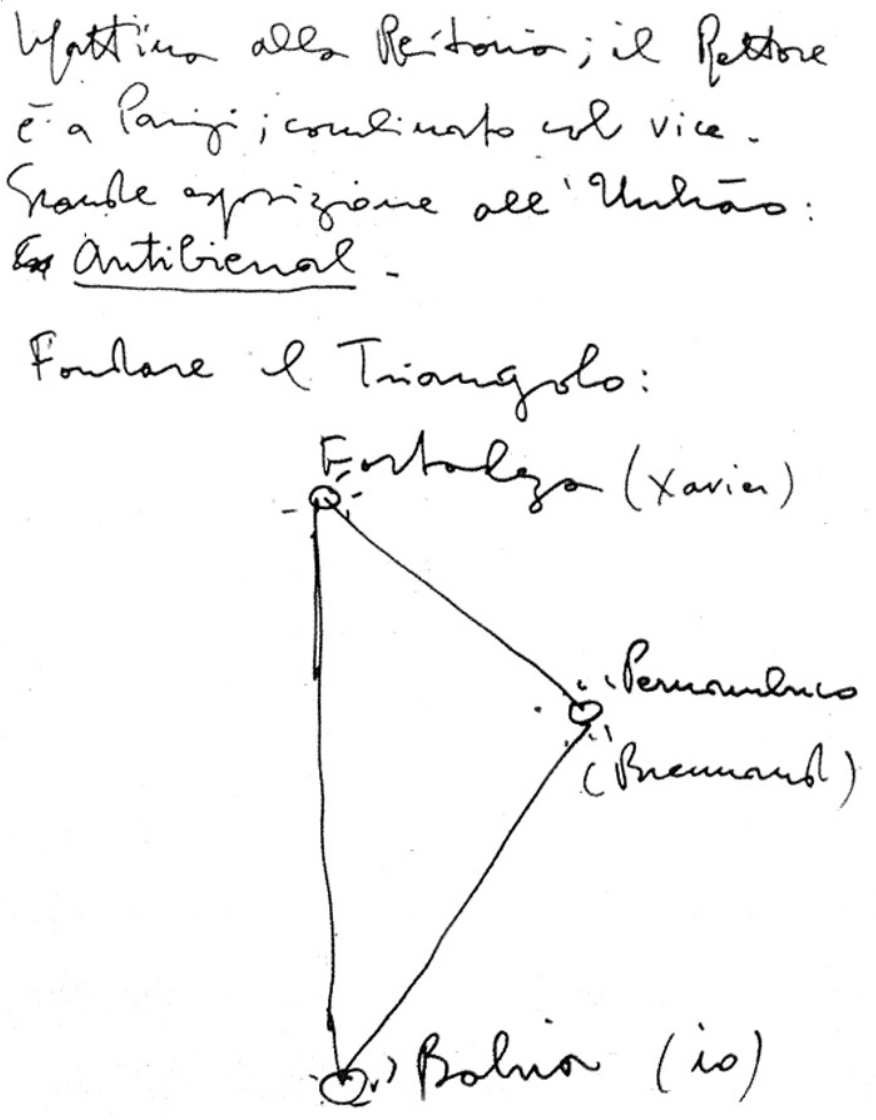

baseado nas raízes populares e, portanto, afinadas com as posturas adotadas por Lina, são encontradas no Nordeste neste momento, como é o caso do Museu de Arte da Universidade do Ceará e o Movimento Popular de Cultura constituído no Recife. Este último é responsável pela proliferação do método de alfabetização de adultos elaborado por Paulo Freire, a Pedagogia do Oprimido, que valoriza elementos da cultura popular e da vida cotidiana dos analfabetos para desmistificar 0 conhecimento científico intelectual.

A relação da arquiteta Lina com a cidade de Salvador se estabelece já no início da década de 1950, quando a arquiteta ainda se encontra em São Paulo, através do reconhecimento e do diálogo com alguns artistas e intelectuais baianos em artigos publicados nas

Fig. 26 Página do diário de Lina. páginas da Revista Habitat. Esta relação também é confirmada pela constante presença da vanguarda soteropolitana nas atividades do MASP23.

Em 1958, Lina é convidada para proferir uma palestra na Escola de Belas Artes da Universidade da Bahia. Durante sua explanação, conforme se observa em artigos da época, a arquiteta fala de temas ligados ao contexto político-cultural esboçado anteriormente, assim como da necessidade da humanização da arquitetura.

Há também que se considerar que o vigoroso processo de substituição da arquitetura tradicional estava sendo promovido pelos arquitetos modernos baianos neste momento. Citando alguns nomes, Hélio Duarte e Diógenes Rebouças são exemplos destes arquitetos atuantes em Salvador que fazem apologia aos avanços tecnológicos, da racionalização e o uso de novos materiais. Neste momento, há uma forte substituição da tipologia arquitetônica existente até então, e consequentemente, uma rápida transformação da

${ }^{23}$ Entre outros, Mario Cravo expõe no MASP em 1950; a bailarina Yanka Ruduzka que dirige a Escola de Dança na Bahia ministra um curso de Dança Expressiva no Museu. 
paisagem urbana, inclusive nos arredores do centro antigo. Conforme Juliano Pereira,

"Quando da chegada de Lina Bo Bardi a Salvador, ainda reinava inconteste, no ambiente da arquitetura soteropolitana, a atitude vanguardista - novidadeira e pioneirística - da incorporação do Movimento Moderno no contexto de uma província periférica, desligada do foco de discussão dos grandes temas que ocupavam o debate internacional na época". ${ }^{24}$

As ações dos arquitetos modernos baianos estavam radicalmente ligadas à vanguarda moderna - no sentido de romper com qualquer forma preexistente de linguagem arquitetônica - e provavelmente provocam algumas observações de Lina. Não se pode deixar de lembrar que é neste momento que o Movimento Moderno está sendo revisado, principalmente no âmbito dos CIAM's. Lina, filha dessa geração do pós-guerra europeu, traz para o Brasil estas preocupações. Em um texto de 1960 sobre o MAMB, Lina oferece alguns indícios sobre sua postura frente às ações promovidas naquele momento em Salvador:

"[...] chegado ao ponto em que a arte moderna é aceita por todos, é necessário começar-se a construir considerando encerrado o período da necessária 'destruição', sob pena de se fazer parte das 'vanguardas retardatárias' e se ser colocado fora da realidade moderna.[...] Uma época nova já começou e quem não chega a compreender sua necessidade lúcida e rigorosa, melancólica $e$ sem pieguice, profundamente poética, corre 0 perigo de ficar de fora. A consciência crítica e a continuidade histórica são grande herança do homem moderno". ${ }^{25}$ (grifo nosso)

É também no ano de 1958 que a arquiteta escreve no Diário de Notícias, caderno de cultura da cidade de Salvador. Os temas assemelham-se àqueles publicados na Revista Habitat e na Revista $A$ sobre a modernidade na vida cotidiana. A arquitetura, o urbanismo, a cultura popular, o patrimônio, 0 folclore ganham destaque. Vale lembrar aqui as impressões de Silvana Rubino sobre esta relação da arquiteta e o patrimônio exposta nesta coluna:

"[...] o tom era o mesmo, entre o irônico e arrogante, empregado na Habitat. É possivel especular se ao incluir o patrimônio histórico da Bahia com tanta ênfase na pauta dessas páginas, ela não estaria mais uma vez se solidarizando ao Sphan - como fez logo nos primeiros números da revista do MASP - reagindo ao que observava na Bahia, ou se situando no campo dos arquitetos modernos como uma arquiteta moderna de segunda geração, da geração que naquele final de década revia os princípios da arquitetura e urbanismo modernos, incluindo temas como identidade, pertencimento e

24 PEREIRA, Juliano. Op.cit., p.62.

${ }^{25}$ BARDI, Lina Bo. Museu de Arte Moderna na Bahia. In: FERRAZ, Marcelo. Op.cit, p.139. 
cultura."26

Apesar da amostra de relevância do serviço ligado ao patrimônio, Lina não deixa de publicar sua opinião sobre 0 aspecto folclórico enfatizado pelos intelectuais envolvidos com a ação de preservação do patrimônio. Neste período, Lina publica algumas referências sobre a proteção e a ação desses bens e 0 paralelo necessário destas questões com a conservação das culturas populares. A arquiteta inicia uma trajetória de conciliação com o projeto de desenvolvimento do Nordeste, através do forte vínculo com a cultura local. Desse modo, abre portas para desavenças tanto com algumas vertentes que apóiam o folclore como fonte através da visão do passado, de forma romantizada, como com aquelas vertentes ligadas ao racionalismo radical ${ }^{27}$. Este enfrentamento com as distintas posições nesse ambiente intelectual baiano permite entender a necessidade da afirmação constante de sua opinião a partir da freqüente publicação de artigos e também do envolvimento com o meio acadêmico. Colocadas em público a opinião frente à atualização e revisão de algumas noções até então consolidadas pelo serviço de tutela dos bens patrimoniais ou mesmo pelos intelectuais envolvidos com as políticas culturais no Brasil, Lina deixa transparecer algumas questões consideradas relevantes no bojo das intervenções em locais tidos como importantes marcos referenciais da cidade, como a noção de memória, de história e da própria investida na prática de conservação.

"a conservação de 'um monumento antigo não significa a conservação de uma vitrina de museu, mas a integração do antigo na vida de hoje. Neste sentido, um edifício não tem que ser isolado, monumentalizado, ao contrário tem que ser humanizado. A conservação do antigo é um problema paralelo à conservação das culturas populares, que não podem ser confundidas com folclore. [...] A integração do antigo na vida de hoje e a valorização cuidada das correntes autenticamente populares, separadas do folclore barato, são os problemas fundamentais do homem moderno"28

Mais tarde, no fim da década de 1970, e com a abertura política no

\footnotetext{
${ }^{26}$ RUBINO, Silvana. Rotas..., op. cit., p.167.

${ }^{27}$ Em 1988, o projeto da Ladeira da Misericórdia é apresentado pela arquiteta para a regional do Sphan. $O$ então arquiteto consultor do Sphan, Diógenes Rebouças, não comparece à negociação e ainda apresenta informalmente uma outra proposta. Conforme Juliano Pereira, é "um estudo preliminar de nítido corte racionalista - uma estrutura mirante de planta semicircular, erguida sobre pilotis - para o mesmo sítio do projeto que estava sendo analisado, na sala anexa". PEREIRA, Juliano. Op. cit., p.63.

${ }^{28}$ Olho sobre a Bahia. Salvador, 24 de setembro de 1958. Apud RUBINO, Silvana. Rotas..., op.cit., p.171.
} 
Brasil, as mesmas questões serão destacadas por Aloísio Magalhães bem como pelos diversos setores que promovem a democracia.

"[...] vários fatores contribuíram, no Brasil e no exterior, para uma mudança sensível na política de preservação. Em primeiro lugar, as disciplinas sobretudo a história e, consequentemente, a história da arte - que fundamentavam a seleção dos bens excepcionais que mereciam ser preservados, passaram por uma mudança de orientação, não só em termos de objeto como também de perspectiva. Em segundo lugar, a essa mudança no campo do saber corresponde a difusão da democracia como valor em outros campos - sexo, etnia etc - que não apenas o do exercício da cidadania política." 29

Convidada para dirigir o MAMB, em 1959, a arquiteta concorda prontamente com tal desafio, uma vez que suas idéias não confrontam com os conselhos dos técnicos da Sudene e os caminhos traçados para o Nordeste. Ao contrário, Lina acredita que a Bahia é um local privilegiado, sem vícios ou modismos já alicerçados no sudeste brasileiro. Lina assume a tarefa de concretizar o museu segundo as prerrogativas já assinaladas anteriormente na Parte 1 desta dissertação: o museu como movimento cultural, como reflexão para as ações na cidade. Nesta empreitada, envolve-se completamente com a busca da cultura popular e do desenvolvimento de um design autenticamente brasileiro. Neste universo de investida na cultura popular, a Universidade da Bahia, principalmente a Escola de Teatro dirigida por Eros Martins Gonçalves, é grande aliada da arquiteta.

O espaço do MAMB, que funcionava originalmente no foyer do teatro Casto Alves, cria uma espécie de "lugar de resistência" da cultura local, vinculado a um programa nacional-popular. A continuidade destes ideais é proporcionada pela restauração do Solar do Unhão para a criação de uma escola de design. "Esses dois projetos, clara e ideologicamente vinculados ao programa político nacional-popular, foram implantados com a firme intenção de funcionar como pólos regionais de irradiação e reafirmação da singularidade, da resistência e da força criativa da cultura local e regional." 30

Antes da divulgação da Carta de Veneza, em 1964, Lina realiza a restauração do Solar do Unhão com muitos indícios da sua atualidade frente às questões metodológicas da restauração em discussão principalmente na Europa e, especialmente, na Itália. A hipótese levantada é a de que sua interlocução 
com Bruno Zevi possa ser um meio de trocas de experiências neste período. Lina fala abertamente sobre as questões colocadas pelo restauro crítico em várias ocasiões. Inclusive considera relevante alguns métodos como forma de atualização do processo de restauração conhecido aqui no Brasil. Lina percebe a defasagem entre as modificações das categorias culturais do nosso serviço de tutela e os métodos de intervenção usados - ainda sob o eco da "fase heróica" do Sphan. A "restituição a um estado primitivo de tempo, de lugar, de estilo"31, método usado pelo nosso serviço de tutela num balanço geral, gerava um ranço pela defasagem existente entre a perspectiva mais abrangente em relação à seleção do patrimônio e a prática em si. A metodologia usada no Brasil ainda em grande parte se limita a idealizar um estilo representativo de uma época, a focar uma unidade de estilo e apagar qualquer vestígio de contraste ou desarmonia. Estes monumentos restaurados criavam uma imagem de unicidade de estilo e de época conveniente aos olhos de um Estado forte e pretendidos por uma percepção mais apurada, uma vez que a contemplação desejada é aquela do olhar intelectual conhecedor, ainda que superficialmente, do contexto histórico ou do estilo empregado num determinado momento. Ou seja, as técnicas usadas faziam prevalecer este valor restrito a um conhecimento mais aguçado e, portanto, não seria imediato. Com isso, limita-se totalmente o foco da percepção para determinada elite cultural ou classe social. 0 valor privilegiado com esta metodologia não condiz com a ampliação dos campos disciplinares - como o da história, da historiografia da arquitetura, da história da arte, da própria restauração - e menos ainda com a ampliação da noção de cultura e os procedimentos mais democráticos na seleção e preservação dos bens patrimoniais.

Acredita-se então que o momento da intervenção no Solar do Unhão é um início da investigação pragmática da arquiteta no modo de como se deveria fazer a relação entre o antigo e o novo aqui no Brasil. Esta experiência decorre principalmente do envolvimento de Lina com as questões museológicas já enfrentadas anteriormente no MASP, sobretudo, a continuidade do desenvolvimento das formas expositivas como fator importante na mudança de foco do objeto em si (obra de arte) para a percepção humana do objeto. As

31 BARDI, Lina Bo. Ladeira da Misericórdia. Publicado na Revista Projeto, n.142, jan/fev, 1992, p.48. 
questões decorrentes desta experiência, principalmente aquelas relacionadas à percepção como momento pedagógico e educativo, acabam trazendo para a intervenção urbana ensinamentos sobre a forma de ampliação do procedimento (principalmente em se considerar os valores simbólicos e afetivos ${ }^{32}$ ) na tarefa de ampliação da prática e coerência com as modificações dos objetivos da política cultural. Também na intervenção no conjunto do Unhão já se estabelecem algumas diretrizes importantes na concepção de uma intervenção mais ampla.

Passando rapidamente para a análise do projeto de intervenção no Unhão, as principais ações sobre o conjunto colonial que podem ser consideradas paralelas às questões desenvolvidas na Europa sobre o modo de se intervir num conjunto preexistente são:

- a seleção daquilo que deveria ou não prosperar no conjunto colonial através de uma análise crítica justificada (aparentemente se utiliza dos conhecimentos filológicos da escola romana para destruir algumas partes adicionadas posteriormente);

- a valorização do conjunto como documento histórico, como nos casos da manutenção de alguns galpões posteriores à data da origem do conjunto arquitetônico (não ambiciona em nenhum momento retomar a unidade estilística do antigo solar) e da manutenção dos trilhos da fábrica de rapé instalados no subsolo do solar no século XIX;

- na consideração da percepção e do presente histórico na inserção do novo através da dissonância. É absolutamente distinguível o que é o novo e o que é o antigo através do contraste lingüístico entre eles. Portanto, é uma intervenção feita a partir das técnicas disponíveis no nosso tempo presente. A reinterpretação poética presente promove pequenos deslocamentos e adições que respondem às questões pragmáticas de uso e cujo resultado não elimina a evocação da atmosfera preexistente - método que proporciona também a valorização do edifício antigo. Como na solução adotada para o MASP, também neste caso Lina permite a entrada da luz natural no salão de exposições. As janelas e portas existentes são mantidas, porém recebem uma pintura vermelha, assinalando a nova intervenção. Alguns elementos de vedação são adicionados

32 A noção de monumento não é somente uma consideração estética-histórica, mas se amplia para valores mais subjetivos, como o simbólico e o sentimental - que conforme Riegl são evocados pelo valor de antiguidade. Esta noção é um início da inserção do campo patrimonial como ato cultural. 
para o fechamento de alguma abertura ou mesmo na divisão dos espaços internos, como, por exemplo, no fechamento da torre sineira da capela. Estas vedações são espécies de elementos vazados em madeira que têm referência na arquitetura popular brasileira - já usados na arquitetura de Lucio Costa. Também estes novos elementos são pintados na cor rubra contrastante, conferindo unidade à intervenção e tornando-a facilmente identificável. 0 novo uso proposto para o edifício direciona as modificações realizadas em todo 0 conjunto, promovendo a passagem do antigo engenho colonial para um espaço de caráter público. $O$ que mais chama a atenção em relação à destinação dos antigos edifícios é o uso do espaço sacro da capela colonial para reuniões ou exposições esporádicas, solução que também será utilizada no projeto da Igreja da Barroquinha33;

- a criação de novos elementos segundo técnicas modernas e de seu tempo. No entanto, o procedimento de criação formal destas estruturas adicionadas posteriormente tem referência diretamente ligada aos modos de fazer tradicional da cultura popular. Ou seja, a criação do novo também parte da preexistência. As novas formas não partem apenas de uma relação entre volumetria, planos, vazios ou não respondem apenas a um cálculo estrutural (o que aqui se tem chamado de referências abstratas - de composição ou de cálculo). As novas formas carregam também um peso simbólico vindo da referência à cultura popular local, das soluções simples e econômicas já encontradas numa realidade material pobre e mísera. É o caso do novo acesso ao piso superior do Solar. A nova escada proposta tem a montagem estrutural inspirada nas técnicas de encaixe tradicionais usados nos carros de boi.

É impossivel deixar de pensar que a interlocução entre Zevi e Lina não assuma alguma posição com relação à inserção do novo em ambientes antigos e à atualidade dos procedimentos de restauro presentes nesta intervenção. Conforme citado pelo arquiteto as questões entre eles perpassam assuntos sobre "o ímpeto criativo e a moderna releitura do passado", sobre a linguagem, a espacialidade moderna e as estruturas tradicionais, etc. Todos os assuntos aludidos por Zevi em sua interlocução com a Lina acabam tangenciando a discussão proposta nesta dissertação. A importância dada à interlocução com

${ }^{33}$ A Barroquinha é uma área que faz parte da intervenção de Lina para o Centro Histórico de Salvador,área esta que será mais adiante detalhada. 
Zevi é ainda mais favorecida pelo período em que Lina passa despercebida pela bibliografia produzida sobre ela, após a data de 1964 - considerado por muitos um momento de "auto-exílio".

Os acontecimentos de 1964 finalizam a ação cultural em Salvador baseada nas manifestações populares, tanto aquelas ações promovidas por Lina, como outras frentes folclóricas percorridas pelos seus opositores. Com o Golpe Militar, Lina é praticamente expulsa da Bahia. Neste mesmo ano, a Exposição Nordeste, montada no Ibirapuera e que deveria também ser apresentada em Roma na Galleria d'Arte moderna, é proibida pelo governo brasileiro, inviabilizando sua ida ao exterior. Este fato é largamente divulgado por Zevi na Itália. ${ }^{34}$

Depois deste episódio, Lina passa um período de "silêncio", mas, no entanto, não se pode negar a importância deste momento. Em 1973, a arquiteta viaja para Harvard ${ }^{35}$ e Roma, o que provavelmente intensifica sua interlocução com os Italianos, principalmente com Zevi. O SESC-Pompéia, em São Paulo, projeto de 1976, pode ser um indício do amadurecimento da discussão sobre a preservação e sobre o enfretamento com a preexistência nestes anos de "introspecção". ${ }^{36}$

Algumas observações sobre a concepção oficial de cultura entre os anos de 1975 e 1985 no Brasil devem ser consideradas antes de se adentrar na concepção do projeto desenvolvido por Lina para o Centro Histórico de Salvador. Mais uma vez, a conjuntura esboçada pretende questionar as afirmações sobre a arquiteta como portadora de "visões" ou mesmo de "invenções teóricas". O que se pretende dizer é que Lina está inserida dentro de um contexto político-cultural da época, afirmando suas opiniões e crenças e que, portanto, estas convicções não devem ser entendidas como pioneirísticas (como afirma frequentemente parte da bibliografia sobre a arquiteta). A Revista do Patrimônio Histórico e Artístico Nacional de 1987 (edição comemorativa dos 50 anos do Sphan) é um documento que revela algumas questões deste período. 0 principal debate envolvido é a relação entre o Estado e a Cultura, no campo da política, da

\footnotetext{
34 "A Arte do povo apavora os generais" publicada no Brasil na Revista Civilização Brasileira. Em Roma é publicado no Expresso di Roma, 1965.

35 Zevi é professor desta universidade.

36 O projeto do SESC-Pompéia é considerado um projeto de restauração, no entanto, não há um estudo aprofundado sobre o tema.
} 
representatividade, da participação democrática, dos conceitos e, por fim, dos métodos envolvidos nas ações de intervenção para fins de preservação do patrimônio ${ }^{37}$. 0 artigo elaborado pelo professor de sociologia Gabriel Cohn é fundamental para a compreensão deste aspecto. ${ }^{38}$

Segundo Cohn, a concepção oficial de cultura nessa década, num rápido exame, propõe a persistência de temas vinculados às mudanças políticas ocorridas na época. No entanto, existe uma constante revisão dos termos. autor pontua pelo menos quatro definições de cultura neste período: 1. a cultura como somatória das criações do homem - herança do processo de criação humana. Este aporte é definido no início da década de 1970 nas gestões de Jarbas Passarinho e Ney Braga no MEC; 2. no fim da década de 1970, na gestão de Eduardo Portella no MEC, a de cultura como modo de ser, da vivência de determinadas parcelas da sociedade; 3. na gestão de Aluísio Pimenta, a cultura passa a ser reconhecida como responsável pelo papel de resistência à dominação hegemônica; 4. na voz de Celso Furtado, a cultura é vista sob sua condição de fonte de criatividade.

O que se pode perceber nestes quatro estágios é que há uma constante preocupação com a "democratização da cultura". A diferença está no sentido atribuído a esta democratização.

"Se em meados da década de 70 se tratava de promover a integração nacional pela difusão de uma produção cultural vista como unitária entre uma população que deveria ser colocada à altura de recebê-la mediante a educação, mais adiante a preocupação maior será com a diversidade das formas e experiências culturais numa sociedade marcadamente estratificada e excludente. [...] A palavra de ordem, então, era a 'descolonização' da cultura, com a possibilidade da formulação de políticas culturais plurais que isso implica." ${ }^{39}$

O respeito para com a "espontaneidade da criação popular" é definido mais adiante como compromisso do Estado com os segmentos da sociedade mais desfavorecidos, o que resulta na concepção de cultura ligada às "formas de sobrevivência" dessas populações, na própria experiência de vida. "Exigências

\footnotetext{
${ }^{37}$ A Carta de Veneza é publicada neste número da Revista. É relevante considerar também que é no ano de 1985 é publicada a Declaração do México a qual discute as políticas públicas, e em 1986 a Carta de Washington, conhecida como carta internacional para a salvaguarda das cidades históricas.

$38 \mathrm{COHN}$, Gabriel. Concepção oficial de cultura e o processo cultural. Revista do Patrimônio Histórico e Artístico Nacional, n.22, pp. 7-10, 1987.

${ }^{39}$ Idem, p.7.
} 
prioritárias e não como excedente em relação a elas"40, explica Cohn. 0 tom populista dá ênfase à idéia de "povo". Estes desdobramentos da concepção de cultura nas políticas culturais, durante os dez anos traçados como referência, têm como concepção a vinculação, ou melhor, a subordinação da política cultural à política social. "Assiste-se a uma gradativa 'socialização' e uma 'politização' da própria idéia de cultura." ${ }^{41}$ Pode-se dizer que este processo atinge o seu máximo por meio do manifesto apresentado na ocasião da criação do Ministério da Cultura ${ }^{42}$. Conforme cita Cohn, o documento reclama que

"[...] a cultura seja amplamente concebida como um processo decorrente dos diversos modos de agir e de pensar da sociedade brasileira. Assim, a política cultural não deverá restringir sua atenção somente a determinadas expressões da cultura, mas estender suas preocupações a aspectos fundamentais desse processo, como, por exemplo: saúde, educação, acesso e uso de solo, trabalho, habitação, etc."43

Nota-se que a cultura tem um sentido derivado dos modos de agir e pensar, o que tem como conseqüência a subordinação da política cultural à política social. Sob a premissa da democratização, há então uma ampliação da concepção de cultura como algo articulado com os demais processos da sociedade. A conseqüência desta ampliação é perceptível no caso analisado de Salvador, desenvolvido mais adiante.

É relevante deixar documentado que esta revista publicada pelo Sphan, além de lançar a questão dos objetivos da política cultural também trabalha com as categorias envolvidas no processo de preservação sob o eco da democratização neste período. As questões sobre o uso e a participação popular ganham importância na discussão da política cultural e dos meios de preservação. No contexto sugerido, a experiência em Olinda antecede algumas demandas no trabalho da prefeitura de Salvador.

Neste período, um projeto que inicialmente visa direcionar os recursos financeiros do Banco Nacional de Habitação (BNH) para a preservação do patrimônio histórico e artístico nacional acaba promovendo os chamados Programas de Recuperação e Revitalização de Núcleos Históricos. Dessa forma,

\footnotetext{
$40 \mathrm{lbidem}$.

41 Idem, p.8

42 Este manifesto é escrito pela sociedade civil e tem com signatário o futuro Ministro da Cultura, Celso Furtado.

${ }^{43}$ Idem, p.8.
} 
a declaração de Vera Bosi ${ }^{44}$ sobre o trabalho em Olinda, publicada na Revista do Patrimônio Histórico Artístico Nacional, contribui para a iniciativa de tentar levar para a prática oficial, em suas várias esferas, as modificações no campo teórico em relação às categorias culturais e consequentemente da política e da gestão 45 Estes trabalhos em Olinda têm início antes mesmo do Programa de Recuperação e Revitalização de Núcleos Históricos ser lançado pelo governo federal ou mesmo antes da criação do Ministério da Cultura, sob o pretexto de viabilizar o diálogo entre as entidades do trato dos problemas urbanos (inclusive o BNH) para lidar com as questões do patrimônio cultural. A experiência positiva de Olinda, no sentido de concessão de interesses no quadro complexo das disputas de poder entre as partes e da metodologia voltada para participação popular, contribuiu para a criação do Programa como modelo a ser implantado pelo Ministério da Cultura, principalmente em cidades históricas. Acredita-se que é sob esta perspectiva que se pode considerar as iniciativas da prefeitura de Salvador.

Em 1986, Mario Kertész assume a prefeitura de Salvador. A nova administração tem uma concepção de cidade como um grande "objeto de cultura". Acredita-se que esta idéia é uma ressonância das colocações sobre a ampliação da noção de cultura postas anteriormente em evidência. É exatamente neste momento que se efetiva a descentralização dos anseios federais. Em Salvador, é criada a Secretaria Municipal da Cultura e se inicia no governo local o Programa Especial de Recuperação dos Sítios Históricos de Salvador (vinculado à Fundação Gregório de Mattos). 0 principal objetivo deste programa é recuperar a vocação do centro da cidade não apenas no seu sentido simbólico, mas também reaver sua condição cotidiana de vida, como o trabalho, a moradia e o lazer. Pode-se considerar que a recuperação do centro está vinculada a uma questão mais ampla, em consonância com problemas locais e a partir da sistematização do território. Há então um procedimento de mudança de escala (território-cidade-centro) e, portanto, uma vinculação das questões de

44 Técnica, na ocasião, da Fundação Pró-Memória (FNpM). Esta instituição foi criada na década de 1980 com a intenção de reunir o conhecimento do PCH, a competência técnica do Iphan e a visão renovada do CNRC. Dessa forma, a nova estrutura era composta por um órgão normativo, a Secretaria do Patrimônio Histórico e Artístico Nacional (Sphan), e o órgão executivo, a FNpM.

45 BOSI, Vera. Participação e pesquisa na preservação do patrimônio cultural. In: Revista do Patrimônio Histórico Artístico Nacional, n.22, pp.138-144, 1987. 
preservação patrimonial a um plano mais abrangente de intervenção. ${ }^{46}$ Com isso, três áreas da cidade são focos do programa da prefeitura: o Poligonal Centro Histórico, o Poligonal Itapagipe e o Poligonal Rio Vermelho. Lina é convidada para conduzir o trabalho do Centro Histórico.

O governo local, concebendo a cidade

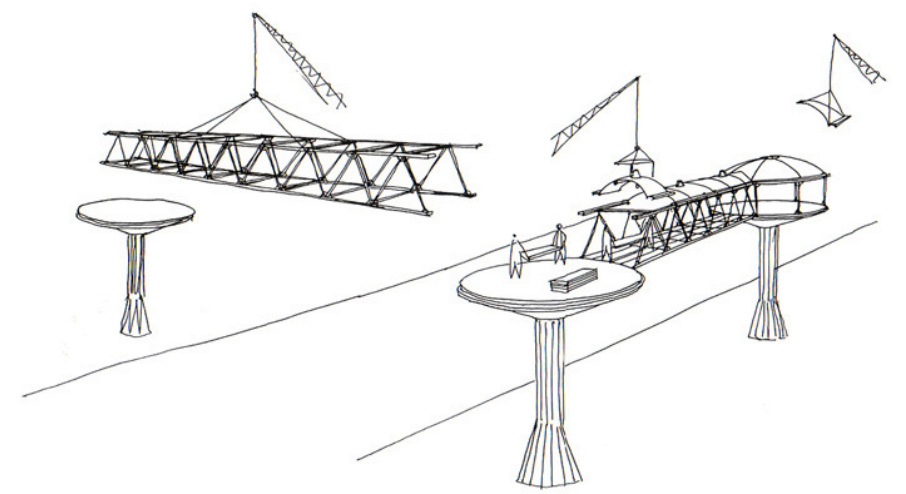
como "objeto de cultura", favorece a leitura geral dos problemas enfrentados pela capital baiana. Com o objetivo de se criar um quadro amplo de intervenção, a prefeitura lança iniciativas para realizar obras públicas em grande escala. Não só o centro antigo deve ser recuperado, mas a cidade como um todo, através da construção de

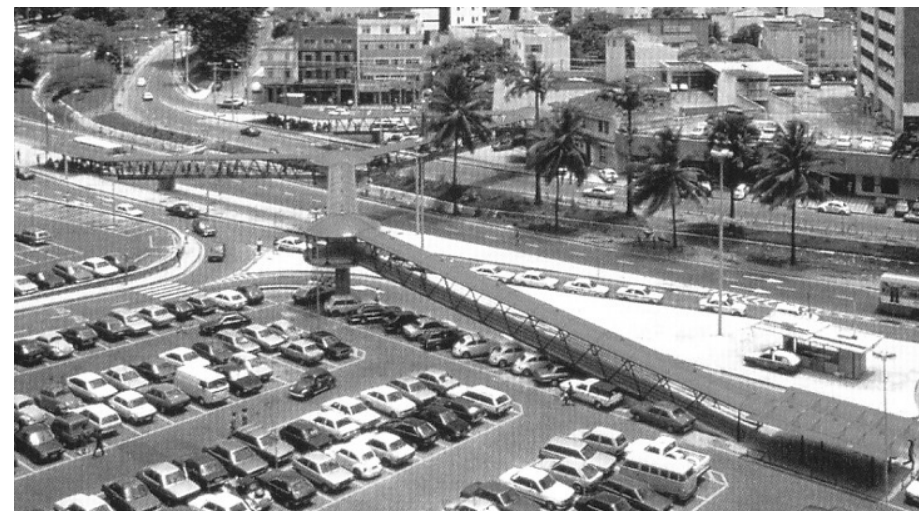
equipamentos públicos: escolas, passarelas, mobiliário, etc. Surge então a Faec (Fábrica de Equipamentos Comunitários da Prefeitura Municipal de Salvador), coordenada pelo arquiteto João Filgueiras Lima, e que objetiva criar elementos pré-fabricados de baixo custo e em larga escala. Os projetos de intervenção no Centro Histórico assessorados por Lina têm como ponto de apoio esta visão geral de

Fig. 27 Passarelas padronizadas produzidas pela Faec em Salvador.

Fig. 28 Implantação. recuperação da cidade.

A concepção de cidade em sua inteireza, nos seus múltiplos espaços diferenciados, e a valorização das distintas características, a complexidade e a pluralidade são chaves de leitura democráticas e que estabelecem uma outra concepção de tempo e de espaço. $O$ antigo tem características que devem ser respeitadas. O novo também tem aspectos particulares. Um não anula a importância do outro; o presente tem importância assim como o passado. Podese afirmar então que nesta visão a cidade é lida de alguma forma como "presente histórico". Dessa maneira, é possível pensar nas aproximações com a arquiteta Lina: na capacidade de valorizar as distintas formas de expressão, suas

${ }^{46}$ Este procedimento da mudança de escala, considerado um modelo corrente na atuação sobre os centros históricos hoje, não deixa de ser uma herança iniciada por Gustavo Giovannoni. Cf. CHOAY,Françoise. Alegoria..., op.cit., p.200. 
pluralidades, representações e riquezas; ser moderno dando continuidade às tradições locais; valorizar a memória viva, cotidiana e telúrica; entender a cidade como um objeto inteiro, em suas diversas escalas; recuperar a função social do arquiteto; não dar margem ao paternalismo ou assistencialismo nas ações públicas.

Também é admissível que o poder municipal democrático deste momento convide Lina, uma vez que a arquiteta é uma das protagonistas da efervescência cultural dos anos anteriores.

\section{a concepção do projeto}

No plano geral da proposta da prefeitura, as frentes de trabalhos são basicamente três:

1. A implantação da Faec;

2. A implantação do Sistema de Transportes de Massa;

3. A criação do Programa de Recuperação e Revitalização dos Sítios Históricos.

No caso do Poligonal Centro Histórico, os principais problemas apontados pela prefeitura são ligados não somente à recuperação do aspecto físico do conjunto arquitetônico, reavendo o valor artístico e histórico envolvido, mas também consistem na recuperação simbólica e afetiva daquele lugar. Considera-se então que nesta recuperação os problemas sociais têm importância equivalente aos aspectos culturais envolvidos. Este fato é visivel pela relevância dada à manutenção do zoneamento local e da população residente nos objetivos principais do projeto. 0 uso existente (comércio e serviços no primeiro andar e habitação popular na parte superior) é considerado um fator relevante na perspectiva e no processo de elaboração do projeto de restauração.

É importante lembrar que a destinação dos monumentos já vinha sendo considerada uma questão prioritária no processo como meio eficiente para atingir o êxito da restauração, principalmente, a partir de experiências de intervenções realizadas internacionalmente, onde se percebe que a expulsão compulsória das dinâmicas existentes e em prol do mercado imobiliário ou da indústria turística acaba desfavorecendo a manutenção da memória que se pretende preservar. Vários são os exemplos de lugares que sofreram as conseqüências da 
modificação radical da dinâmica cotidiana local. 0 tema da destinação faz parte do escopo das discussões internacionais sobre as questões relativas à tutela, 0 que fica mais visível na década de 1960, principalmente com a publicação da Carta de Veneza. No entanto, cabe aqui considerar que o uso e a destinação têm como objetivo primeiro seu aspecto conservativo, verificado na seguinte ressalva desta carta:

"A conservação dos monumentos é sempre favorecida pela destinação deles a funções úteis à sociedade; tal destinação é portanto desejável mas não pode nem deve alterar a disposição ou decoração dos edifícios. É somente dentro destes limites que se deve conceber e se pode autorizar as modificações exigidas pelos usos e costumes." 47

O objetivo da destinação do patrimônio pela prefeitura da capital baiana, no entanto, refere-se a outros caminhos. A própria chancela da recuperação da cidade em larga escala acaba conformando um processo de restauração agregado aos problemas sociais. Resulta também numa preocupação conservativa bem diversa daquela proporcionada até então pelo Sphan, o qual tem como fim uma envergadura cultural aliada principalmente aos problemas artísticos. Numa visão mais ampla, sabe-se que a prefeitura se coloca o desafio de criar uma política pública de proteção que não aquela tradicionalmente herdada, vinculada ao aparelho burocrático estatal instrumentado sob ações autoritárias e limitadas a uma determinada classe social ou intelectual. $\mathrm{O}$ objetivo é criar meios que melhor representem a pluralidade e 0 acesso à cultura para 0 maior número de cidadãos. No entanto, fica a dúvida sobre o verdadeiro entendimento da palavra "restauração" envolvido neste caminho.

As atuais definições de restauração, principalmente aquelas definidas no território do campo disciplinar, excluem qualquer prerrogativa que tenha como fim último outros critérios que não os culturais ${ }^{48}$ - 0 que justifica a ressalva na Carta de Veneza, anteriormente citada, sobre a destinação do monumento sob certos limites. A questão do uso, portanto, torna-se um meio para a perpetuação do objetivo cultural.

No entanto, a proposta de restauração da prefeitura de Salvador parece englobar também aspectos de outras partes da cidade. Restaurar ganha um sentido amplo, de "consertar", de dotar a cidade de qualidades ambientais

${ }^{47}$ Carta de Veneza. Op.cit, p.94.

48 CARBONARA, Giovanni. Avvicinamento al restauro. Teoria, storia, monumenti. Napoli: Liguori Editore, 1997. 
através de intervenções não excludentes. As conseqüências da ampliação da definição de cultura no âmbito da política cultural parecem gerar um efeito duvidoso sobre os métodos que envolvem a restauração. Ignora-se toda uma deontologia do campo disciplinar da Teoria da Restauração. 0 aspecto social ganha um sentido privilegiado que interfere no objetivo e na definição de restauração. Este aspecto duvidoso que diz respeito ao sentido de restauração deve-se também ao esquema construtivo proposto em ampla escala. Num primeiro momento, parece perigoso conceber o projeto de restauração com 0 mesmo sistema construtivo adotado na cidade inteira: na produção pré-fabricada em argamassa armada a fim de diminuir os custos e assumir toda a cidade. Apesar de parecer algo promissor, em se considerar principalmente a possibilidade de diminuir custos e ter um grande alcance, fica a dúvida se 0 resvalamento do sistema construtivo industrial em larga escala no processo de restauração é resultado da liberdade criada com a ampliação da definição de cultura e o extenso sentido de "restauração" colocado pela prefeitura, ou ainda, é de fato algo proposital, visto que o valor artístico é menos considerado na área do conjunto do centro histórico baiano. Sabe-se que, no caso da Bahia, o valor atribuído ao centro histórico vinha principalmente por parte da relevância documental do modo de ocupação pitoresca de uma cidade-colônia portuguesa. As edificações não são consideradas exemplares tipológicos de grande valor artístico, no sentido de riqueza de detalhes ou minúcia do modo de fazer colonial. Inclusive, acredita-se num caráter quase "provisório" das edificações. ${ }^{49}$ Há então uma hierarquia de valores já estabelecida pelos estudos sobre a história da ocupação da cidade e que dá menor peso à artisticidade deste conjunto urbano. Dessa forma, abre-se a perspectiva de se considerar uma maior liberdade durante as intervenções mais isoladas, no caso, através do uso em larga escala da tecnologia industrial. Esta problemática só é colocada aqui porque durante 0 processo de intervenção a questão dos valores é frequentemente trabalhada e aparece em algumas falas da equipe de intervenção. O professor Maurício Chagas, que participou de perto do projeto de execução do Projeto Piloto Ladeira da Misericórdia, mostra os valores principais

49 HOLANDA, Sérgio Buarque de. Raízes do Brasil. São Paulo: Schwarcz, 1999, p.110. Ver também REIS FILHO, Nestor. Quadro da arquitetura no Brasil. São Paulo: Perspectiva, 1983. 0 professor Maurício Chagas também faz referência a este assunto. CHAGAS, Maurício. Op.cit, pp.156-157. 
que Lina quer preservar:

"Para ela, o que realmente vale é a percepção antropológica da vivência do lugar, o modus vivendi da sua população e o conjunto indissociável formado por relevo, tipologia construtiva, morfologia dos espaços públicos e 0 uso cotidiano. [...] Busca com isso, mais que contextualização e afirmação das diferenças, um projeto social abarcando os conflitos e contradições do mundo real $[. . .]^{\prime \prime 50}$

A pergunta é: neste caso, o aspecto "artístico", deixado em segundo plano, acaba condizendo com a flexibilidade do significado da palavra restauração? Sendo a artisticidade um elemento subjacente aos fatores sociais e documentais na concepção de cultura envolvida neste caso específico, a restauração poderia seguir outros rumos que não aqueles pretendidos pelo Sphan ou mesmo aqueles colocados pelo campo da Teoria da Restauração? Proposital ou não, o desafio é posto em questão: fazer uma restauração em larga escala.

Apesar do perigo que se coloca em relação ao conflito entre as novas definições de cultura e os meios de conservação e restauração, não se desconsidera a ampliação do campo e nem mesmo o desafio do uso da técnica construtiva industrial no projeto de restauração. É possível valer-se da mesma técnica construtiva para produzir equipamentos públicos e elementos para a restauração do centro antigo? Esta questão parece bastante importante na medida em que poderia ser um tema colocado no momento da reconstrução no pós-guerra europeu, após a destruição em massa. No entanto, não se encontram, na bibliografia, ações que promovam tal iniciativa. As soluções construtivas em larga escala na Europa do pós-guerra geralmente são usadas na construção do novo, principalmente para sanar os problemas do déficit habitacional. Ao contrário, as propostas construtivas nos projetos de restauração são definidas caso a caso e não previamente (como é o exemplo da proposta da prefeitura de Salvador). Seria Salvador um momento de conciliação das disciplinas através de uma proposta híbrida?

O desafio colocado pelo uso de um sistema estrutural pré-fabricado para a construção em larga escala - inclusive na restauração - não deixa de ser uma engenhosidade possível. Contudo, só é possível graças à posição crítica $\mathrm{e}$ à percepção artística e histórica individual da arquiteta Lina. No caso da

50 Idem, p.157. 
intervenção do Centro Histórico de Salvador, o uso da tecnologia industrial tem uma adaptação promovida no próprio desenvolvimento do projeto e na sua execução. Cada caso continua sendo particularizado neste sentido. Para tanto, acredita-se em se fazer "projetos pilotos", aprimorando os elementos préfabricados e os processos de adaptação in loco para depois ampliar a solução no restante do tecido histórico. A técnica industrial só é aceitável porque o processo abrange basicamente duas etapas: aquela de fabricação industrial dos elementos pré-fabricados através de fôrmas de aço, utilização de mão-de-obra qualificada e rigoroso controle de qualidade, e a segunda, mas não menos relevante, a do canteiro, adaptando-se aos problemas particulares de cada edificação. ${ }^{51}$ Neste sentido, a ação não garante uma solução esquemática e repetidamente usada sem que se leve em conta a preexistência. No entanto, durante o processo, a consideração do valor artístico ou histórico é de inteira responsabilidade de uma arquiteta (no singular), na sua percepção e envolvimento com as questões de cunho cultural. A invenção do modo de usar a técnica construtiva industrial através de uma adaptação à tradicional e particular forma de implantação do conjunto mostra a capacidade criativa da arquiteta. A criação do novo e da tecnologia moderna não deixa de lado os limites colocados pela preexistência e os aspectos culturais envolvidos neste contexto. Contudo, estes limites são percebidos exclusivamente por Lina, de forma que, ainda que exista uma liberdade criativa, há também um respeito para com a construção antiga e a preexistência. $O$ que é preciso chamar a atenção é que, apesar do uso da tecnologia padronizada, o modo de inserção desta tecnologia se difere em determinados momentos conforme o locus em que será implantada. É então através do limite entre o antigo e o novo, ou melhor, entre criatividade e respeito presente nas intervenções de Lina, que se pode considerar o seu procedimento. Trata-se de uma sensibilidade individual e particular. E, por conta deste mesmo limite entre 0 antigo e o novo, é possível encontrar várias classificações sobre a arquiteta na bibliografia procedente: ora considerada adepta do movimento moderno; ora considerada representante do restauro crítico no Brasil; ora aproximada aos arquitetos do Team $\mathrm{X}$; ora comparada ao arquiteto italiano Carlo

${ }^{51}$ Nesta segunda etapa é usada grande quantidade de mão-de-obra pouco qualificada. 
Scarpa. ${ }^{22}$ Essas analogias e aproximações são possiveis principalmente por aquilo que já foi apontado no início deste estudo, ou seja, pela possibilidade do diálogo entre 0 antigo e 0 novo presente durante toda sua experiência e formação: a formação propedêutica a partir dos preceitos giovannonianos, a destacar, a articulação mais orgânica entre as novas necessidades e o conjunto antigo; a preocupação com a nova percepção crítica do homem moderno através da observação da metodologia usada no desenvolvimento das formas expositivas na Itália (como metáfora da forma de inserção do novo na cidade); a referência à cultura popular como referência na construção do novo. Também não se pode deixar de enfatizar a revisão dos arquitetos do pós-guerra a respeito da dimensão cultural existente no lugar e o que isso implica enquanto procedimento. Como foi colocado na primeira parte da dissertação, o desejo desta geração em devolver o valor simbólico e cultural da cidade acaba gerando a necessidade de reavaliar os procedimentos de projeto - o que promove a revisão de algumas categorias intrínsecas à prática da preservação. Ao mesmo tempo, nesta época, a própria investida sobre a restauração ganha novos aportes, afirmando também a necessidade de dar soluções que espelham 0 tempo presente. Neste sentido, existe um movimento de aproximação entre os campos de atuação na cidade e na arquitetura, o que justifica também as constantes interlocuções entre Bruno Zevi, Cesare Brandi e Roberto Pane - para citar as discussões já colocadas aqui e que, de certa forma, aproximam-se de Lina através do diálogo com Zevi.

Dessa maneira, pouca contribuição oferece a iniciativa de classificar 0 trabalho de Lina segundo uma ou outra linha de intervenção. O importante aqui é refletir sobre 0 limite estabelecido pela arquiteta durante seu procedimento criativo. É através do possível diálogo entre 0 antigo e 0 novo durante 0 procedimento do projeto que se pode apreender a contribuição da arquiteta,

52 Marcelo Suzuki enfatiza, em entrevista concedida à autora desta dissertação, a postura de Lina como arquiteta moderna. É considerada partidária ao restauro crítico por Ana Carolina Bierrenbach. BIERRENBACH, Ana Carolina. Lina Bo Bardi: tempo, história e restauro. Revista CPC, n.3, nov/2007 abril/2006, p.6-32, p.6-32. Disponivel em: http://www.usp.br/cpc/v1/php/wf07_revista_interna.php?id_revista=7\&id_conteudo=18\&tipo=5. Acesso dia 11/12/2006. Marco De Michelis fala da obra de Lina como uma revisão da crítica do Movimento Moderno paralelamente ao debate dos últimos CIAM's e da reflexão do TEAM X. DE MICHELIS, Marco. Prefácio. In: FERRAZ, Marcelo. Op.cit. Cecilia Rodrigues dos Santos compara Lina a Carlo Scarpa, principalmente na atuação no Museu de Castelvecchio, em Verona. In: SANTOS, Cecília Rodrigues. Assim, nas bordas e por dentro, os ratos foram roendo toda nossa cidade da Bahia. Revista Projeto, n.142, jan-fev, 1992, p.56. 
principalmente nas atuações em locais considerados importantes marcos referenciais da cidade.

Vale lembrar que, enquanto procedimento, não existe hoje uma visão que repudie a abertura ao novo em intervenções sobre ambientes vetustos. No entanto, segundo Giovanni Carbonara ${ }^{53}$, os meios usados para a inserção do novo diferenciam-se enquanto método (ou na própria inexistência dele). Por um lado, a abertura ao novo contribui para que a cidade não seja vista como um objeto cristalizado no passado ou se inicie um processo de "musealização" da cidade. ${ }^{54}$ Por outro, a aceitação do novo proporciona uma aparente liberdade ou mesmo uma constante arbitrariedade através do deleite individual do arquiteto. Dessa maneira, os danos causados atingem, na maior parte, a parcela mais fraca da proposição: a antiga (e, na maioria das vezes, esses danos são irreversíveis). Entre os extremos da inserção do novo (a destruição e a máxima proteção) existe a preocupação em se considerar o diálogo segundo uma metodologia científica aplicada. Contudo, não existe ainda hoje uma autêntica consciência a respeito dos métodos de inserção do novo com o intuito de se considerar este diálogo. Considera-se que o novo deve ser "respeitoso", ou melhor, ter "qualidades" suficientes para fazer o antigo ter sentido novamente. Estes princípios postos provocam uma total incompreensão na medida em que são objetivos abstratos e apenas adjetivam as ações, mas não referenciam uma prática concreta. As ações se justificam e se desenvolvem sob termos absolutamente genéricos: "qualidade", "respeitoso", "sentido", etc. 0 que resta como categoria objetiva no ato de criação do arquiteto são as normas referentes às edificações ou aos Planos Diretores. Porém, estas regras e normas (evidentemente necessárias na atuação da preservação patrimonial) não são categorias que justifiquem as ações no âmbito do restauro arquitetônico.

É necessário então retomar alguns pontos importantes das modificações no campo da restauração, principalmente aqueles sustentados pelo

${ }^{53}$ CARBONARA, Giovanni. Avvicinament..., op.cit., p.186

${ }^{54}$ As chamadas "cidades-museus" são resultados de uma extremada preocupação com a proteção destes lugares. O próprio conceito de "centro histórico" é na verdade uma noção que apenas garante a função proibitiva dos profissionais da área da tutela sob a desmerecida cristalização daquele limite constituído de cidade. Cf. Argan "o mesmo conceito, porém, é teoricamente absurdo porque, se se quer conservar a cidade como instituição, não se pode admitir que ela conste de uma parte histórica com um valor qualitativo e de uma parte não-histórica, com caráter puramente quantitativo. Fique bem claro que o que tem e deve ter não apenas organização, mas substância histórica é a cidade em seu conjunto, antiga e moderna." Cf. ARGAN, Giulio Carlo. História da..., op.cit, p.79. 
restauro crítico e a teoria de Cesare Brandi, para que se possam entender alguns entraves da problemática contemporânea, principalmente sob o foco de uma metodologia mais palpável.

Como já foi dito, a Segunda Guerra Mundial provoca a necessidade de revisão das bases metodológicas pela incompatibilidade do procedimento filológico reticente até então com a situação de extrema destruição daquele momento. Retoma-se primeiramente a noção de restauro como ato cultural. Essa conjetura reforça a idéia de ligação direta às exigências da memória, ou seja, ao valor permanente e à duração histórica mais que qualquer outra hipótese - como aquelas ligadas aos objetivos de uso prático. Conclui-se então que restaurar configura um ato intelectual, com acento fortemente científico e portando evidentemente a atenção crítica somada à competência técnica. Não responde a regras pré-fixadas, mas constitui em si a reinvenção, caso por caso, através de critérios e métodos específicos. O processo crítico é bastante distinto do processo filológico: necessita-se de uma preparação do profissional no campo da história artística e arquitetônica e de operar com competência técnica para assegurar sua capacidade criativa. Essa criatividade garante, conforme Carbonara, uma solução particularizada em cada caso. ${ }^{55}$ No entanto, a criatividade é encaminhada segundo 0 aporte da conservação, o que na prática "si tratta quindi d'intendere il restauro come azione mirante al recupero della vera immagine dell'opera che, come vedremo, può essere cosa diversa dall'immagine originale e non ha nulla a che fare con le tentazioni della vecchia 'unità di stile"'56 0 restauro faz coincidir ação crítica com processo criativo, objetivando não apenas tutelar 0 documento histórico mas também atualizar a imagem figurativa da obra, ou melhor, valorizar a dupla polaridade artística e histórica existente na obra. Ratificando, trata-se de uma criatividade que promove a dialética antigo/novo, onde o novo é conduzido pelo processo histórico-crítico usando-se de princípios e métodos como atribuição objetiva. Enquanto procedimento criativo poder-se-ia então aproximar Lina da proposição do restauro crítico.

A proposta da prefeitura de Salvador de "restaurar" a cidade como um todo, somada à idéia de usar uma tecnologia industrial em larga escala num projeto de restauração, abre espaço para um procedimento que daria margem ao

${ }^{55}$ CARBONARA, Giovanni. Avvicinament..., op.cit, p.186.

56 Ibidem. 
distanciamento de uma ação conservativa, uma vez que o uso da técnica modular e seqüencial poderia ignorar as particularidades locais e tradicionais. Lina, ao deparar-se com estas questões, não deixa de afirmar a importância do valor cultural como foco da intervenção. A criação do novo é colocada sob o aporte crítico da preexistência. Este procedimento, como já dito, é um limite criado de inteira responsabilidade da arquiteta.

Outro aspecto parece importante: as diferentes abordagens contemporâneas preconizam, sem exceção, o respeito absoluto pela matéria antiga como inegável documento de valor histórico - o que ainda segue as mesmas preocupações de Lina. Apesar da leitura das obras de Lina parecerem afinadas em relação a estes limites da criatividade para a inserção do novo em ambientes antigos, o processo diferencia-se de um projeto de restauração em alguns aspectos. Apesar dos variados aportes encontrados, todas as vertentes atuais de restauro ${ }^{57}$ convergem no sentido de fundamentar a discussão através de um incontestável processo racional e científico. Portanto, o processo metodológico é justificado e cientificamente aprovado por uma equipe multidisciplinar. Dessa forma, conclui-se que a restauração tem um método a ser seguido, no qual engloba uma série de fatores ligados à conservação do patrimônio, como o reconhecimento do objeto como obra de arte, a pesquisa sistemática sobre o assunto, a documentação das etapas do trabalho, as indicações das intervenções apontando para o futuro, a possibilidade de reversibilidade e a publicação das ações promovidas. Ao deparar-se com 0 material do projeto de restauro do Centro Histórico de Salvador, percebe-se que não há nada comparado com o rigor técnico de um projeto de restauro. Além da falta de documentação do processo de execução das obras, a própria representação do projeto evidencia uma liberdade incomparável com outros projetos de restauro, pois, na maior parte são aquarelas, desenhos narrativos ou croquis.

Por outro lado, é importante considerar a realidade deste campo da restauração no Brasil. Definitivamente, as ações promovidas pelo serviço de preservação do patrimônio, o Sphan, ainda que promovessem a atualidade das questões sobre patrimônio e objetivos da preservação, na verdade, não

57 Hoje existem basicamente três tendências no campo da restauração: a "crítico-conservativa", a "conservação integral" e a "manutenção-repristinação". Idem. 
conseguiam efetivá-las em sua ação pragmática. Em outras palavras, apesar da revisão das categorias envolvidas no âmbito da preservação durante a modernização do Sphan na década de 1980, o que se produz nas restaurações é ainda uma ação idealizadora - decorrente dos métodos que ainda reproduzem as idéias promovidas no século XIX. Dessa forma, considera-se importante a proposta de Lina, principalmente no desafio de modificar a operação da restauração descompassada em relação ao novo discurso. Para isso, Lina aproveita-se do conhecimento adquirido em sua formação na Itália, da idéia de modernidade envolvida na sua geração, da interlocução com Zevi, e - como instrumento mais palpável na América Latina - dos princípios da Carta de Veneza, como o uso da tecnologia do seu tempo sem, no entanto, perder de vista o valor artístico e histórico do antigo; da valorização do valor documental da obra na consideração das várias estratificações (materiais e humanas) impressas com o tempo; da não aceitação da unidade estilística como fator preponderante; da resistência à falsificação ou imitação das formas passadas. Antes de especificar estes procedimentos, é necessário entender a proposta geral da intervenção.

A concepção do projeto para o Centro Histórico de Salvador é previamente elaborada pela prefeitura local a partir das premissas já apontadas. Conforme foi citado, a idéia da intervenção é promover ações pontuais sobre 0 território e através da reverberação do processo de intervenção em seu entorno, como "focos de irradiação". 58

O projeto consiste na intervenção em algumas áreas pólos do Centro Histórico, como o Belvedere da Sé, o Largo do Pelourinho, a Ladeira da Misericórdia, o Projeto Barroquinha, o Conjunto Benin na Bahia, a Casa do Olodum, a Fundação Pierre Verger, a Casa de Cuba na Bahia, a Casa da Bahia em Cuba, a Casa da Bahia no Benin, além de toda a organização urbana de equipamentos, fluxos de pedestres, mobiliário, etc ${ }^{59}$.

A valorização do aspecto documental do urbanismo colonial acaba delineando um princípio fundamental do projeto: "preservar as ruas áridas e os quintais repletos de vegetação; a idéia do casario, como um conjunto sólido,

\footnotetext{
${ }^{58}$ CHAGAS, Maurício. Op.cit., p.159.

${ }^{59}$ A oposição do Sphan local às idéias da arquiteta acabam causando o veto de sua intervenção nas três praças. Ainda assim, os projetos pilotos são orientados por ela.
} 
formado por muros, compondo uma enorme muralha"60. Dessa forma a unidade das quadras é entendida como prioritária. A idéia do projeto proposto por Lina e equipe é que as lacunas do tecido, como ruínas ou terrenos baldios, seriam preenchidas com construções novas, recuperando a idéia de conjunto. A vegetação exuberante existente no interior das quadras e que se contrapõe à aridez das ruas deveria ser recuperada. Estas áreas internas deveriam ter um tratamento coletivo, uma vez que os casarões poderiam ser utilizados por famílias diferentes ou mesmo porque teriam um caráter de uso cultural. 0 acesso ao interior das quadras seria feito através do térreo de um dos casarões, buscando não agredir a conservação do próprio quarteirão e das fachadas contínuas alinhadas sobre o passeio. As fachadas internas e externas deveriam conservar a hierarquia já existente, com prioridade às fachadas voltadas para a rua. As construções anexas, principalmente no interior dos quarteirões, deveriam também ser objetos de investigação uma vez que poderiam agregar 0 valor documental e singular do conjunto através de adições posteriores à data de construção do conjunto colonial. Caso comprovada sua relevância documental, estas adições, deveriam ser conservadas, apesar da desarmonia da unidade estilística do conjunto.

A ambientação urbana seria garantida através da recuperação da infraestrutura básica, da fiação subterrânea, da proposta de iluminação adequada, da circulação de pedestre em praticamente todo o perímetro histórico, da proposta geral de acesso à área, incluindo transporte coletivo e bolsões de estacionamento. 0 projeto se daria a partir de um percurso que ligasse as principais praças da área: a Praça da Sé, o Terreiro de Jesus e o Largo do Pelourinho. Neste percurso, a ação se resumiria ao aspecto da infra-estrutura, detalhamento de piso, equipamentos e mobiliário urbano. Este projeto não foi implantado, principalmente por questionamentos do IPAC ${ }^{61 .}$

60 WIPFLI, Mônica. Op. cit., p.130.

61 São consideradas ações bastante "incisivas" no conjunto e por isso questionadas. 


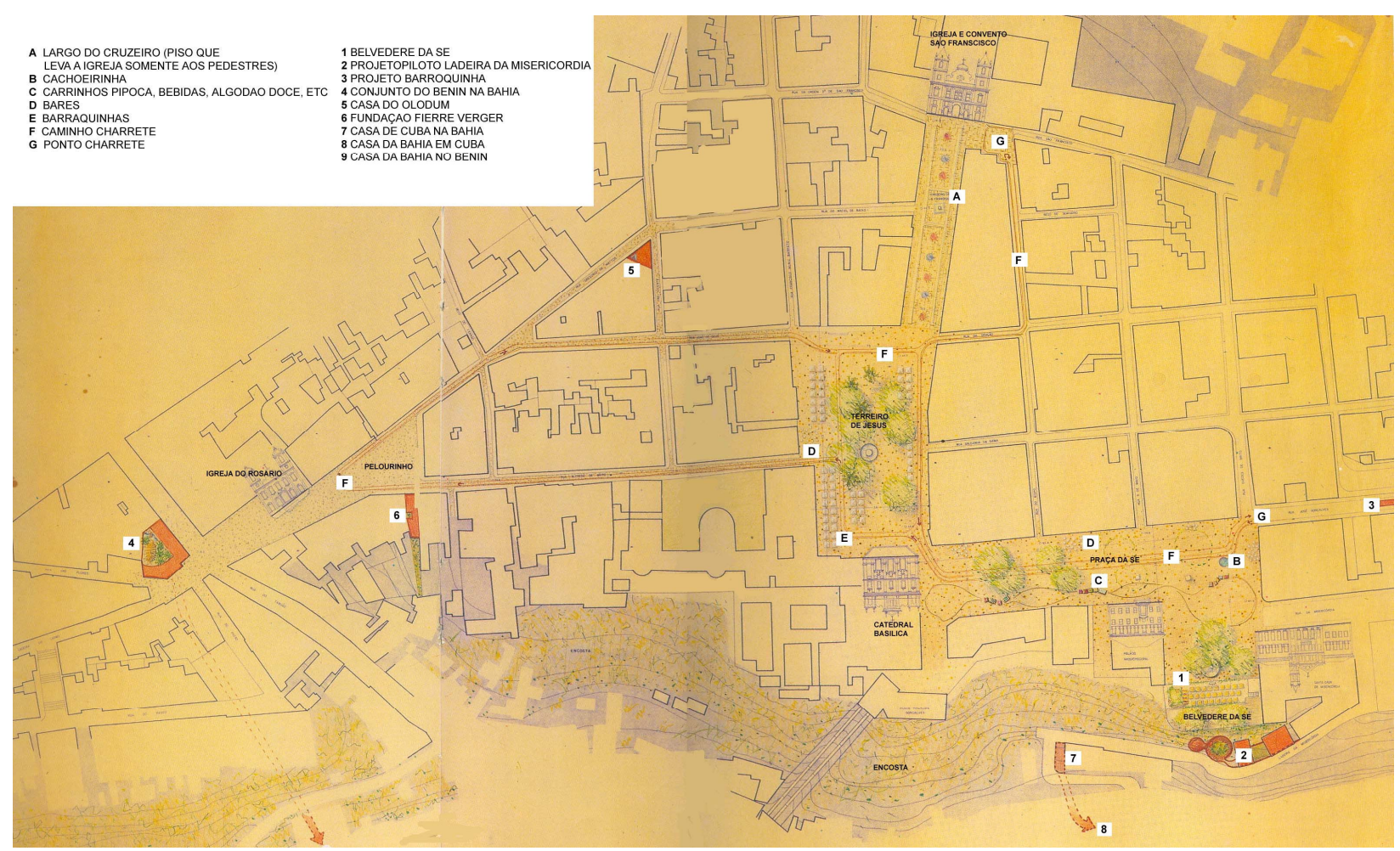

Fig. 29 Planta geral do projeto de intervenção no Centro Histórico de Salvador. (legenda adicionada pela autora da dissertação)
O Belvedere da Sé é uma área de extrema importância histórica na fundação da cidade. Conforme colocado anteriormente, esta área sofre transformações importantes, como a derrubada da Sé e a abertura da avenida de acesso ao centro, o que acaba modificando sua concepção espacial inicial. Depois da demolição da Sé, a área configura-se como uma abertura perspéctica do tecido pitoresco antigo para a Bahia de Todos os Santos. Numa leitura morfológica do tecido, esta área é ponto de início e fim de uma série de praças e largos abertos e iluminados, as quais contrastam com as ruas serpenteadas, sombreadas e íngremes do centro antigo. O Belvedere da Sé, após esta demolição, modifica sua característica de praça "fechada" e, ao contrário das outras praças, transforma-se num local que se abre para o mar, a partir do qual se pode compreender o aspecto específico da implantação geográfica da cidade. Ou seja, sua configuração torna-se análoga à Praça Thomé de Souza, cuja implantação seria considerada principal localização da "entrada" da cidade para quem chega do mar.

O projeto para esta área volta-se à valorização das características existentes naquele momento, principalmente, para a contemplação da cidade e do mar. Lina propõe um quiosque com uma choperia para criar um espaço de 
encontro e de "estar", além de bancos sob grandes árvores existentes e um palco para apresentações espontâneas. Esta proposta foi realizada, no entanto, em 1992, o terraço foi demolido dando lugar a uma nova praça.

Todo o percurso entre as principais praças é detalhado segundo um trabalho de criação inspirado em referências simbólicas encontradas no nordeste, nas festas populares, na cultura popular. A pavimentação das praças a do Cruzeiro de São Francisco, por exemplo - faz referência à imagem poética das ruas cobertas de flores nas procissões, nas festas religiosas. 0 mobiliário segue o mesmo raciocínio.

Várias propostas são apresentadas pensando no uso espontâneo das pessoas. A criança - personagem principal da personalidade espontânea - é frequentemente citada no projeto. Os elementos urbanos criados têm uma referência lúdica. Estes elementos aparecem no tecido urbano de forma surpreendente: um trem para crianças, um palco, uma flor de concreto, uma roda d'água, uma cachoeira. Estes novos elementos parecem evidenciar uma vontade de preenchimento das áreas com usos cotidianos já experimentados e percebidos por Lina. Estes novos usos não são excluídos do espaço público, ainda que este espaço apresente um valor histórico documental importante. A criança, protagonista da espontaneidade, não é excluída; sua espontaneidade é provocada no percurso urbano com estes novos elementos. O habitante é convidado a interferir na cidade.

Apesar das condições sociais diferenciadas, esta proposta tem uma aproximação com os arquitetos pertencentes ao Team X, principalmente, com o holandês Aldo van Eych. Eych realiza pesquisas que buscam novos critérios de composição e de percepção espacial que não aqueles sustentados pelo racionalismo na arquitetura. "Essa elaboração formal busca uma redefinição da relação entre o homem e o espaço construído [...]".62 Apesar dos arquitetos usarem um repertório formal diverso - Eych utiliza-se de formas geométricas elementares através de "pares opostos" e Lina, de formas simbólicas e representativas da cultura popular -, ambos não acreditam que o lugar se basta

62 BARONE, Ana Claudia. Op. cit., p.110. Este arquiteto faz viagens por algumas aldeias africanas com interesse em entender a vida das comunidades e sua organização espacial através dos rituais e expressões culturais. "Era também um estudo de como a organização espacial de aldeias primitivas constitui aspectos fundamentais para a manutenção dos valores e da identidade de tais grupos humanos". Idem, p.112. 
pela proposta racional das necessidades através apenas das construções. A aproximação entre os dois arquitetos acontece quando se pretende criar um diálogo com as formas de percepção do espaço. A obra somente se completa na presença dos usuários, na interação e apropriação desses espaços. Também no trabalho de Eych as crianças são incluídas no espaço urbano quando não se criam áreas infantis segregadas, possibilitando lugares flexíveis em soluções que fazem parte da própria cidade. "Cada um desses objetos não encerra na sua forma plástica uma função, mas se recria cada vez que é reutilizado, numa estética que não se resolve totalmente na sua concepção, mas que se completa com a presença do usuário."63 No caso de Lina a função não se restringe ao valor de uso mas se amplia no seu valor simbólico e afetivo. A proposta e a experiência dos museus na relação entre 0 antigo e o novo desenvolvida na Parte 1 deste estudo acaba projetando para a cidade uma metodologia. 0 novo não é escamoteado ou imitativo do antigo. 0 que se pretende aqui é também possibilitar uma nova percepção de quem usufrui da cidade. 0 objeto de intervenção não é o principal foco, mas o modo de perceber, as práticas sociais. Acredita-se que o uso seja o meio de se preservar o bem patrimonial - entendase bem patrimonial não apenas no sentido material.

Estas propostas, como já dito, são vetadas pelo serviço de patrimônio local e não são realizadas.

casa do benin na bahia

A Casa do Benin, idealizada por Pierre Verger, foi criada com o objetivo de funcionar como um centro cultural voltado para a cultura negra - o primeiro de uma série de lugares destinados às culturas formadoras da nossa identidade.

$O$ conjunto é formado por dois casarões e um terreno vazio adjacente. $A$ idéia é promover através desta intervenção uma espécie de exemplo da recuperação futura de todo o tecido do centro antigo. Além do trabalho específico de recuperação dos casarões, esta intervenção também permite esclarecer algumas idéias iniciais do projeto, como o trato das lacunas do tecido urbano antigo, a solução empregada no quintal interno coletivo e o tratamento das fachadas internas. Estes casarões já tinham sido objetos de intervenção em administrações anteriores.

63 Idem, p.124. 


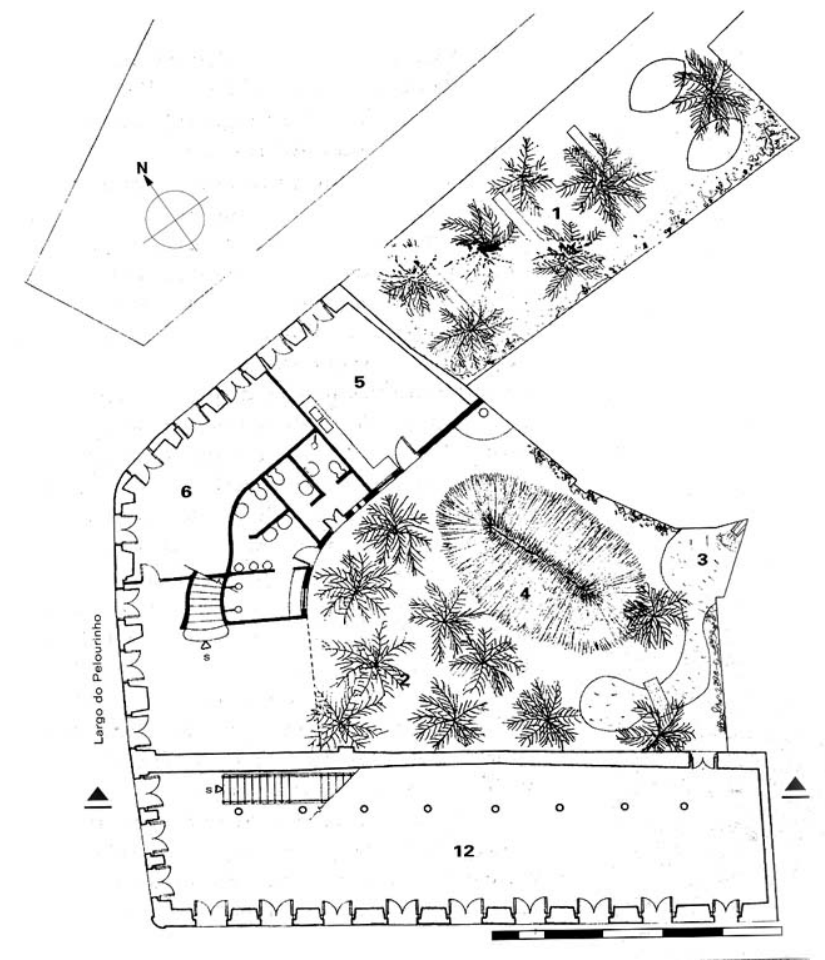

Fig.30 Planta do térreo. 1.Praça; 2.Jardim do Benin; 3.Cascata; 4.Restaurante; 5.Cozinha; 6.Depósito; 12 Exposição.
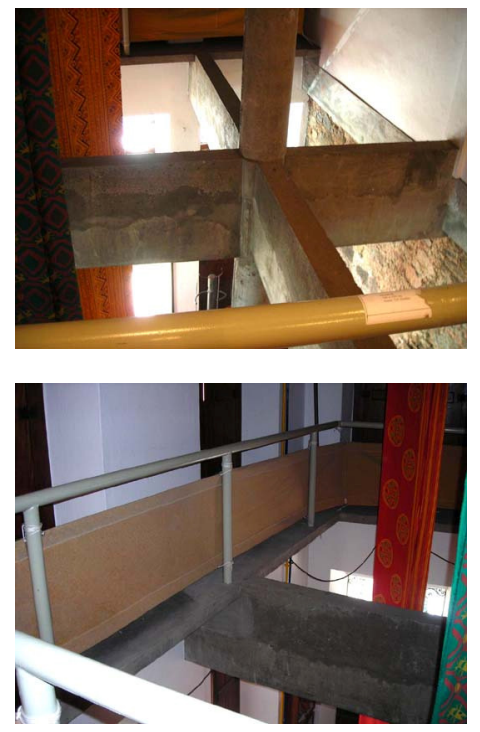

Fig.31 Estrutura de concreto aparente na parte do mezanino.

Fig.32 Passarela que correm paralelamente à fachada, ao lado das janelas.
A proposta da administração anterior consiste basicamente na estabilização do edifício antigo através da inserção de uma estrutura de concreto armado composto por pilares e vigas. 0 uso da tecnologia moderna na concepção da estrutura nova inserida sobre o casarão colonial corrobora com a indicação da Carta de Veneza sobre o uso de materiais do tempo presente na restauração de edifícios antigos. Não se faz imitação nem falsificação das estruturas preexistentes: aparece então um traço de atualidade sobre as discussões a respeito da relação entre 0 antigo e o novo em andamento junto à comunidade interessada nas metodologias de restauro. Concede-se então a possibilidade da presença da tecnologia moderna em ambientes antigos. No entanto, a concepção espacial do antigo edifício, a qual consiste num amplo espaço livre, é totalmente rompida por este "paliteiro" de pilares enfileirados. Além disso, as vigas de concreto que sustentam a laje do segundo andar têm altura estrutural enorme se comparada às alturas dos barrotes de madeira antigos, o que sobressai incisivamente na percepção de quem visita o lugar. Com a proposta de um mezanino num dos lados do casarão, esta estrutura fica ainda mais evidente. Sem a laje, gigantes pilares e vigas de concreto ocupam este espaço, conformando um enorme esqueleto aparente na parte interior. A fachada, com isso, ganha um aspecto de "casca" envoltória solução que é desconsiderada na proposta de Lina, principalmente no projeto da Ladeira da Misericórdia. Nesta parte do mezanino, com pé-direito duplo, estão presentes estranhas passarelas no interior do edifício paralelamente às janelas, com o único fim de tornar possivel abrir ou fechá-las.

Há um muro de pedra paralelo à fachada principal que originalmente funcionava como muro estrutural do edifício. A distância entre muros (muro de pedra e fachada principal) é estreita quando comparada à dimensão total voltada para a rua. A sensação de lugar estreito e comprido fica ainda mais gritante com esta intervenção da administração anterior, com sensação provocada pelo 

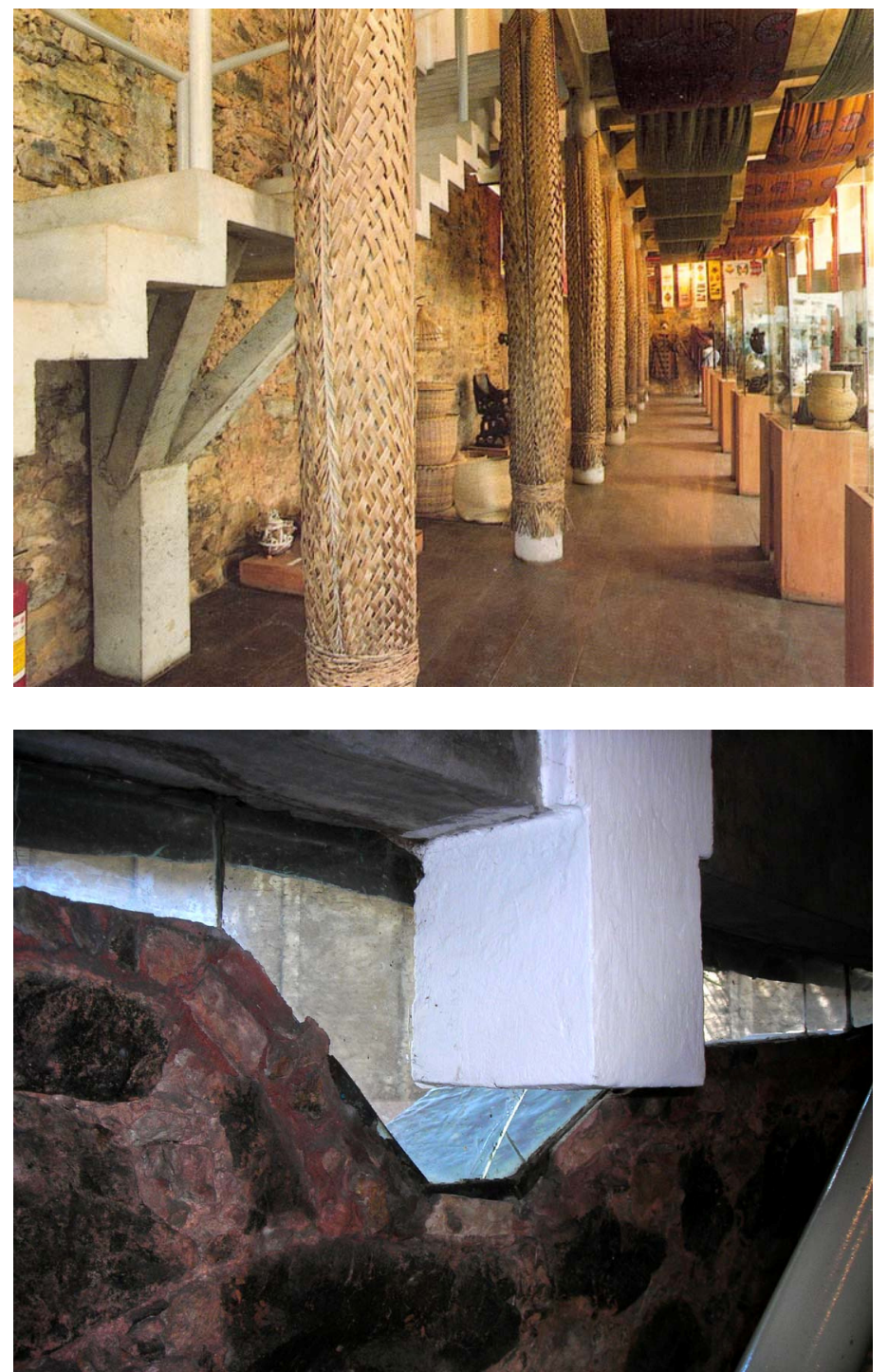

alinhamento dos enormes pilares de concreto colocados a cerca de um metro do muro de pedra. Portanto, a pouca profundidade do edifício é ainda mais sensível com este alinhamento de pilares. Nesta espécie de vão entre pilares e muro de pedra há uma escada de concreto armado usada como acesso ao pavimento superior.

A primeira ação na proposta de Lina é retomar, ou melhor, amenizar estas sensações de estreitamento do espaço provocadas pela intervenção da gestão antecedente. Apesar da nítida vontade de retomar 0 grande ambiente livre e espaçoso do antigo edifício colonial, Lina, ainda assim, considera a intervenção anterior. Neste trabalho, a arquiteta diferencia as estratificações temporais, deixando as distintas formas de construir, os materiais $e$ as tecnologias totalmente à mostra. Portanto, a intervenção da administração anterior é evidenciada, assim como o edifício antigo. Existe uma vontade de "denúncia" esquemática do

Fig.33 Área interna destinada à exposição. Percebe-se a estrutura de concreto armado; a seqüência de pilares colocados paralelamente ao muro de pedra; as vigas de concreto escondidas sob os panos. Os pilares são revestidos por folhas trançadas.

Fig.34 Desvencilhamento do muro de pedra e a estrutura de concreto armado através de um vão. tempo transcorrido, e inclui-se nesta denúncia a própria forma de intervir, ou seja, de se relacionar com o passado. Na parte térrea, retira-se todo 0 revestimento do muro antigo de pedra e evidenciam-se explicitamente as duas técnicas construtivas sobrepostas: vedações leves de alvenaria sob vigas de concreto armado versus o muro de pedra auto-portante. Lina mostra e ordena cada proposição explicitando seu funcionamento. Propõe então que cada sistema retome a sua autonomia enquanto funcionamento estrutural. São separadas através de um vão que é simplesmente vedado com um vidro transparente e de onde se pode ver o azul do céu. 0 muro antigo isostático, desligado da cinta de concreto por esta fresta, retoma o seu sistema e funcionamento "portante".

Neste intuito de rompimento e procura de uma nova percepção, os 
pilares também são objetos de atenção. A repetição dos robustos pilares é atenuada por uma solução simples e "pobre" que advém, sobretudo, do design. Lina soluciona a questão através de uma nova ambientação: reveste os pilares de folhas de coqueiros trançadas à mão. A altura do pilar é rompida com uma espécie de vestimenta com outra textura e cor. As folhas trançadas, material efêmero e de pouca durabilidade, fazem apologia aos modos de trabalhar 0 trançado no Benin. A solução é mísera, mas propõe abrandar a ignorância da antiga sensação do espaço contínuo e "elegante" da arquitetura colonial brasileira.

Outros elementos são incorporados ao projeto, como o guarda-corpo da escada e das passarelas e uma escada de acesso aos dormitórios do sótão. Estes elementos também se diferenciam do projeto posterior no uso de estruturas metálicas ao invés do concreto armado. A leve estrutura metálica adicionada é distinguível e contrastante tanto com o edifício antigo como com 0 projeto de intervenção anterior. A pintura branca das fachadas do edifício é propositalmente um marco da nova intervenção - conforme acontece no Solar do Unhão e nos outros projetos posteriores.

Um restaurante e um novo paisagismo são propostos no quintal. Esta área interna é tratada como uma espécie de "oásis" e diferencia-se totalmente da edificação existente através de uma concepção formal inspirada na cultura popular africana, como uma tapera de barro vermelho de cobertura de palha, absolutamente diversa do ambiente exterior. 0 estranhamento é proposital. Há um contraste impiedoso entre 0 exterior e 0 interior através da presença de elementos naturais, do sistema construtivo e do uso de materiais incomuns ao tecido de "pedra e cal". O resultado é uma espécie de cenário contrastante entre culturas e tempos. 0 interior do restaurante resume-se a uma grande mesa oval comunitária coberta que retoma a antiga forma de relação coletiva tradicional do ato da refeição: solidária, comunitária. Resgatar estas práticas, o modo de comer e de conviver, é tão importante como a criação deste contraste entre arquiteturas. Resgatar o modo de usar faz parte da construção do programa do projeto. Lina convida para esta experiência. Retoma-se, sobretudo, a relação simbólica: espacial e humana. Apesar do aspecto "tribal" da tapera (e até mesmo do mobiliário), a criação do novo segue um desejo moderno de simplicidade, de economia e funcionalidade. 0 exemplo aqui descrito retoma o procedimento 

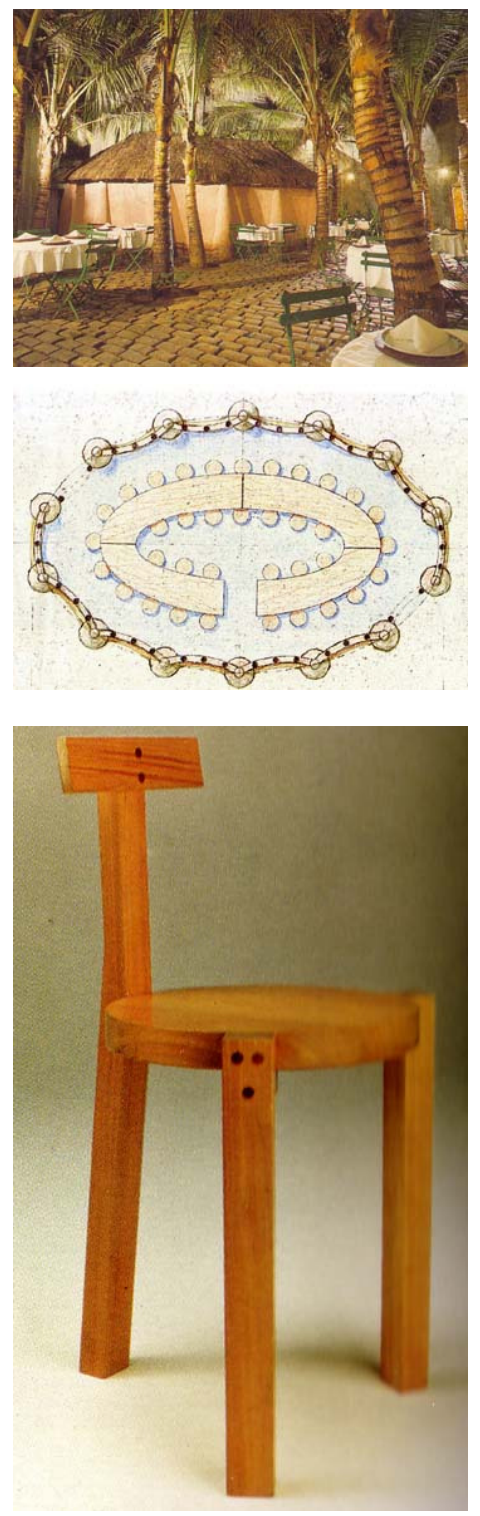

Fig. 35 Vista do restaurante no jardim interno.

Fig.36 Planta do restaurante com a mesa comunitária.

Fig.37 Cadeira "girafinha" do restaurante. criativo incentivado no Unhão, vinte anos antes, sobre a criação através da continuidade da tradição cultural vinculada à origem, às necessidades primordiais. No entanto, as referências usadas - negras - são totalmente estranhas ao tecido - branco. Há um contraste proposital, um estranhamento que talvez retome a sensação de estar "fora de lugar" dos africanos vindos para 0 Brasil. A forma tem forte referência simbólica da cultura afro e assim se pretende. Procura-se, sobretudo, retomar as relações afetivas e simbólicas com o Benin. $O$ estranhamento causado é dado principalmente pelo fato do espaço apresentar-se como objeto cenográfico, ou seja, que não é construto social, mas criação de alguém. Lina inventa uma paisagem a fim de comprometê-la logo em seguida. A criação de um ambiente cenográfico acaba provocando a reflexão sobre esta paisagem. A sensação de objeto "fora de lugar" é proporcionada pela criação de uma ambiência diversa daquela encontrada na Bahia. As técnicas usadas na construção desta ambientação como os materiais, as técnicas, bem como o modo de usar, são extremamente contrastantes com o lugar.

Há que se considerar que a paisagem é um fenômeno além da morfologia, ou seja, está vinculada com um espaço social ${ }^{64}$. Através deste método de contraste e estranhamento entre paisagem e espaço social, Lina mostra as diferenças e o diálogo forçado entre 0 antigo e o novo criado. Denuncia a violência do ato colonizador na indiferença sobre estes aspectos culturais durante a simples inserção do negro numa paisagem que não the diz respeito. Dessa forma, a arquiteta parece inverter o processo de esfacelamento das culturas tradicionais durante a colonização. Ao invés de apagar os vestígios da cultura colonizada, Lina a retoma e a reconstrói. É possível entender esta inversão através da reflexão sobre a estruturação do espaço como ato de cultura e do pensamento simbólico descrita por Lévi-Strauss:

"A distribuição circular das palhoças em torno da casa dos homens é de tal importância, no que diz respeito à vida social e à prática do culto, que os missionários salesianos da região do rio das Garças rapidamente descobriram que a maneira mais segura de converter os Bororo consistia em obrigá-los a abandonar as suas aldeias, trocando-a por outra, onde as casas são dispostas em filas paralelas. Desorientados relativamente aos pontos cardeais, privados da planta que fornece um argumento para o seu saber, os indígenas perdem rapidamente 0 sentido das tradições, como se os seus sistemas sociais e religioso fossem muito complicados para passarem sem o esquema, tornando patente pela planta da aldeia e cujos contornos são perpetuamente refrescados

64 MENESES, Ulpiano T. B. A paisagem como fato cultural. In: Turismo e paisagem. Rio de Janeiro: Contexto, 2002. Ver também ARANTES, Antonio Augusto. Paisagens..., Op. cit. 
pelos seus gestos cotidianos." ${ }^{65}$

Lina faz exatamente 0 oposto dos salesianos. Retomar as práticas e 0 espaço como referência é um modo de provocação, de reflexão: o espaço não antecede e nem é fruto dos fatos sociais. São dois planos em paralelismo, interdependentes. E aqui reside a sua provocação e denúncia sobre a ignorância das culturas que também fazem parte de um repertório cultural brasileiro. Este exemplo mostra um procedimento nada convencional para as metodologias de restauro, mas que também suscita questões relativas à cultura e à ampliação das políticas culturais. Mostra então uma liberdade enquanto metodologia durante a relação estabelecida entre passado e presente, ou melhor, entre antigo e novo.

\section{ladeira da misericórdia}

"Será um sistema de pré-moldados, perfeitamente distinto da parte histórica, que será denunciado pela sua estrutura e pelo tempo atual. Não vamos mexer em nada, mas vamos mexer em tudo."66

Uma das ligações mais antigas entre cidade alta e cidade baixa de Salvador foi escolhida como projeto piloto de intervenção e que deveria propagar-se como exemplo na área do Pelourinho. A escolha dessa Ladeira se

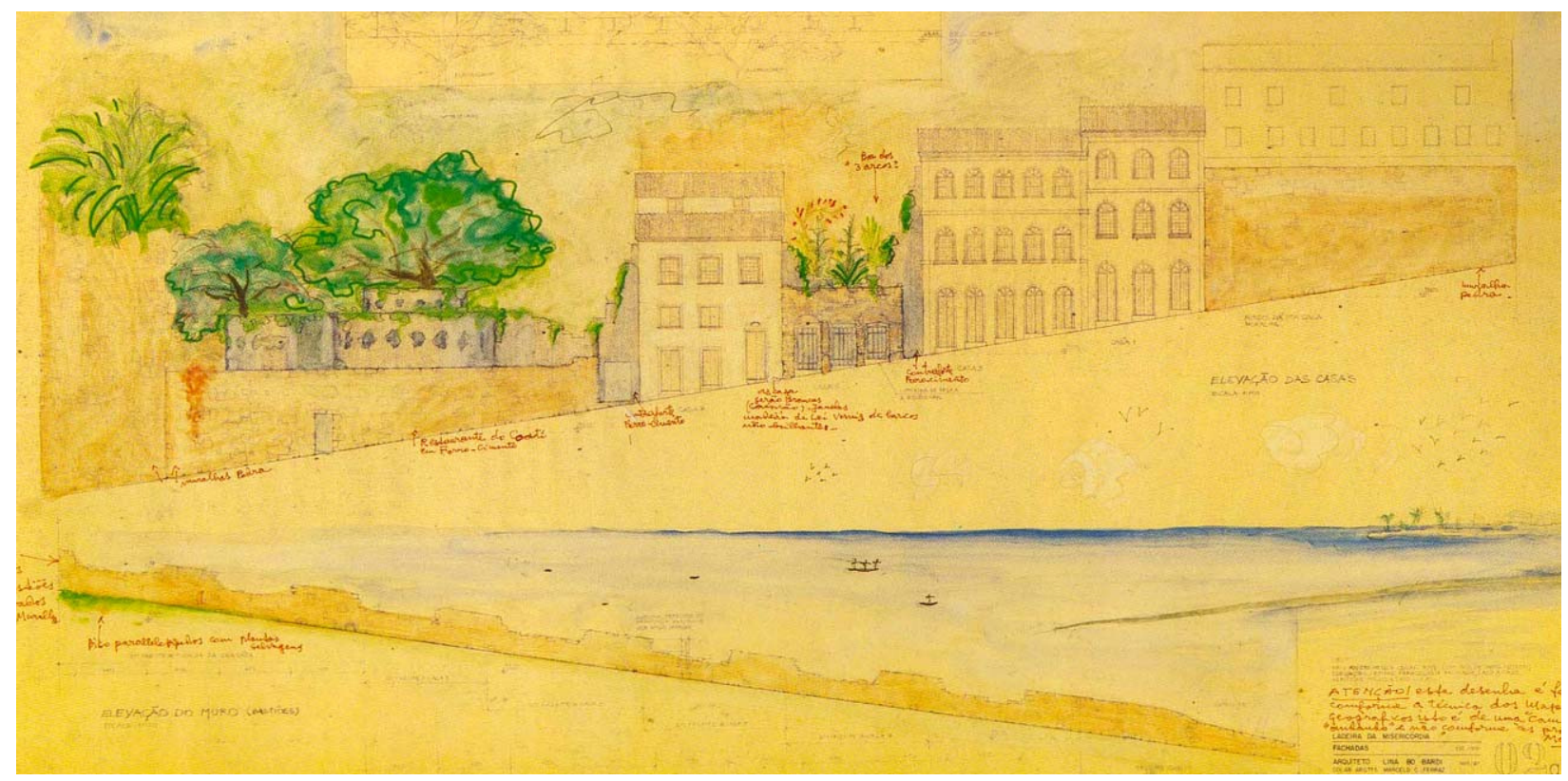

Fig.38 Desenhos de Lina.

${ }^{65}$ LEVI-STRAUS. Tristes tópicos, apud ARANTES, Antonio Augusto. Paisagens..., op.cit, p.84.

${ }^{66}$ BARDI, Lina Bo. Ladeira..., op.cit, p.48. 
dá devido à sua pequena extensão, à própria idéia de recuperação de um importante acesso ao Centro, à baixa ocupação dos edifícios ali existentes, pela ótima localização e acesso para a execução da intervenção, pelas diferentes abordagens proporcionadas pelo conjunto (existiam casarões ainda inteiros, outros destruídos ou outros, ainda, em ruínas).
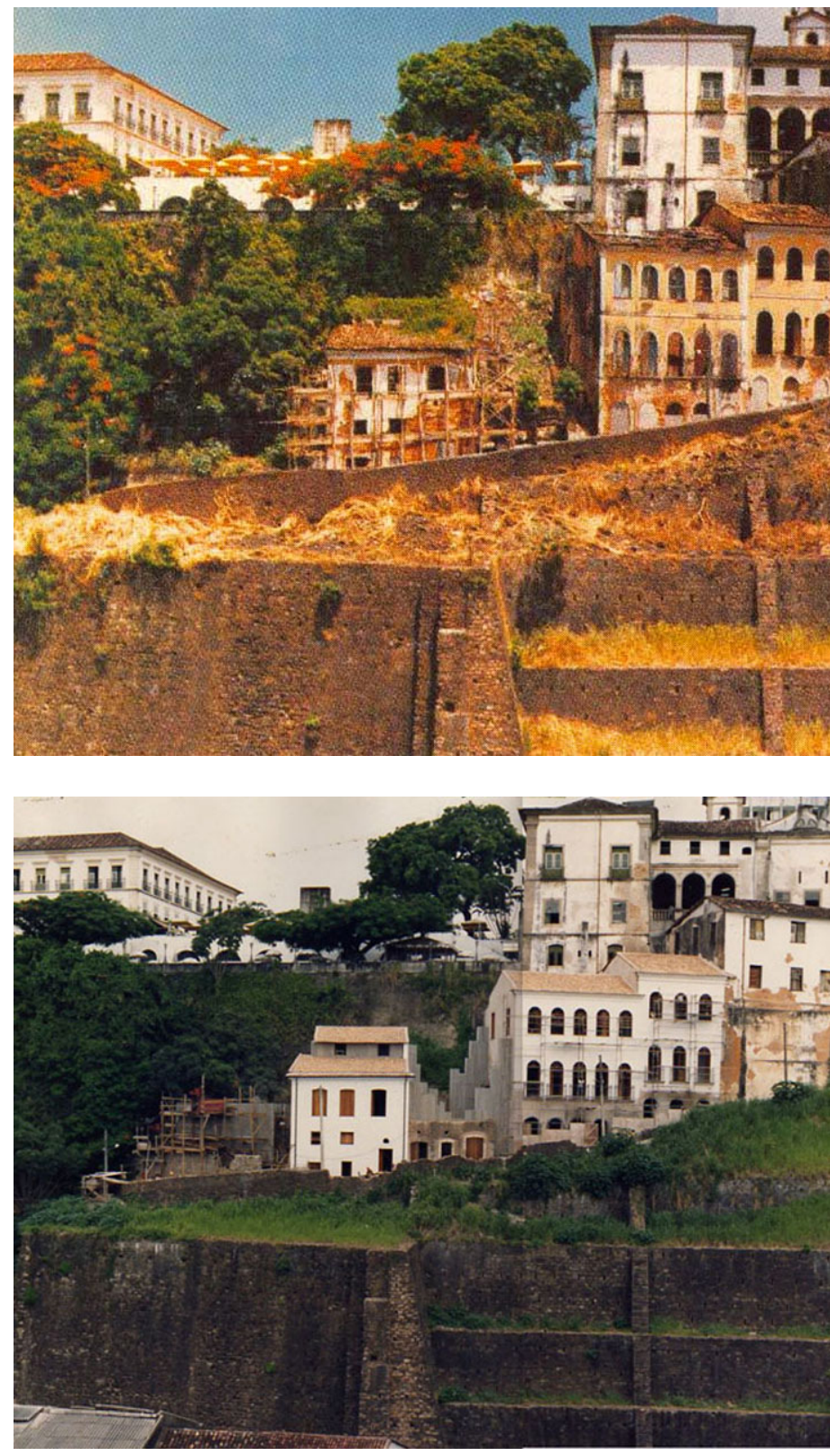

A ladeira está situada num lugar privilegiado, num declive que dá acesso a uma das principais praças do Centro, de um lado casarões implantados sobre alvenarias de pedras, de outro a visão do mar. Compõe uma espécie de "fachada" da cidade, onde se intercalam os edifícios em linha, a abundante área verde sobre os taludes, os muros de arrimo de pedra e por fim a lacuna da Igreja da Sé. 0 projeto consiste na intervenção em três casarões, uma ruína e um terreno baldio, além dos serviços de infra-estrutura, iluminação, drenagem e revisão dos muros de contenção. $A$ destinação destes imóveis é aquela prevista anteriormente pela prefeitura, de habitação popular nos pavimentos superiores e pequenos comércios e serviços no térreo. Para a ruína e o terreno baldio são propostos novos usos, destinados tanto ao público local como forasteiro.

A proposta de intervenção resume-se ao seguinte postulado: deixar o que lá está apenas estabilizando as estruturas existentes retomando os espaços conforme suas características espaciais, como as grandes salas

Fig.39 Estado da Ladeira da Misericórdia em 1986.

Fig.40 Ladeira da Misericórdia durante a intervenção, em 1989. sem pilares cortando os espaços -, sem imitar a técnica antiga, mas valendo-se da tecnologia do seu tempo. As adições de construções posteriores, caso estivessem em péssimo estado, deveriam ser retiradas e transformadas em terraços - estas áreas seriam áreas comuns entre os habitantes. São áreas 
destinadas à secagem de roupas ou serviços comuns. As adições posteriores em bom estado seriam mantidas, como é o caso do sótão adicionado posteriormente no último casarão (número 7). Para as novas intervenções

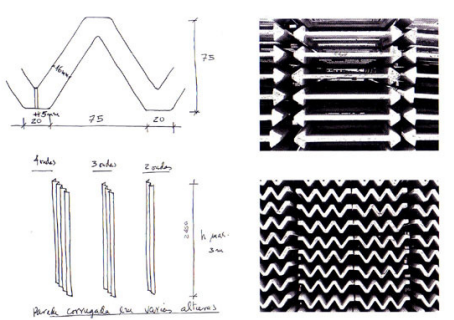
segue-se o mesmo sistema estrutural das estruturas de consolidação, no entanto, com maior liberdade formal. Neste sentido, os painéis plissados colocados paralelamente e preenchidos com areia para a consolidação das paredes antigas transformam-se em paredes monolíticas para os projetos novos.

Conforme indica Maurício Chagas, arquiteto que acompanhou

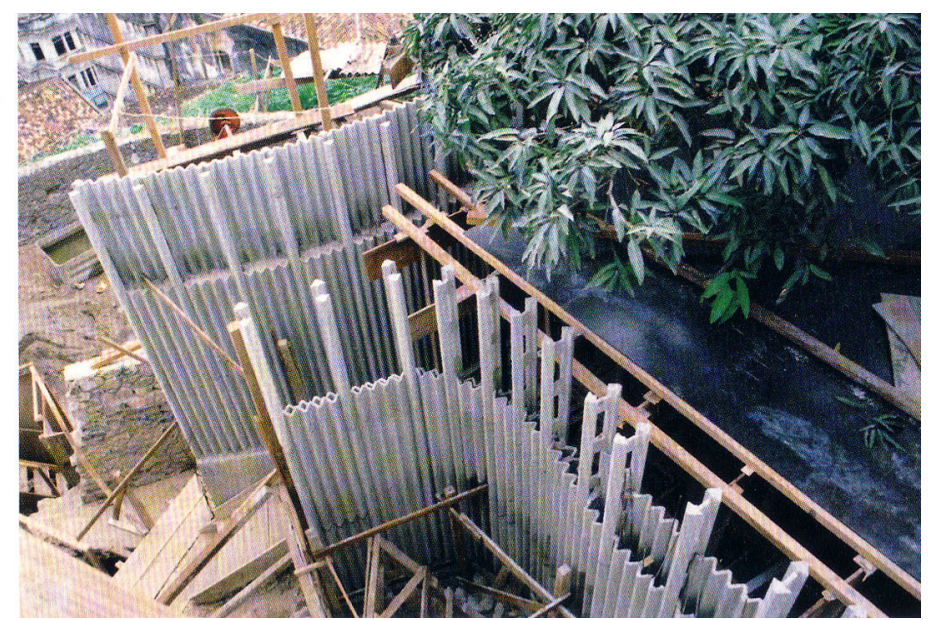

diretamente este projeto, alguns componentes pré-fabricados formavam o repertório do sistema estrutural:

"- módulos de lajes isostáticas de $65 \times 65 \mathrm{~cm}$, tipo caixão perdido, 30 e $40 \mathrm{~cm}$ de espessura, armadas nas duas direções e vencendo vãos de até $6 \mathrm{~m}$;

- placas divisórias planas para divisões internas;

- placas plissadas (com duas, três e quatro ondas) e altura máxima de três metros, usadas nos contrafortes e nas contenções, e

- escadarias ajustáveis no local" 67

Os três casarões têm a estabilização do

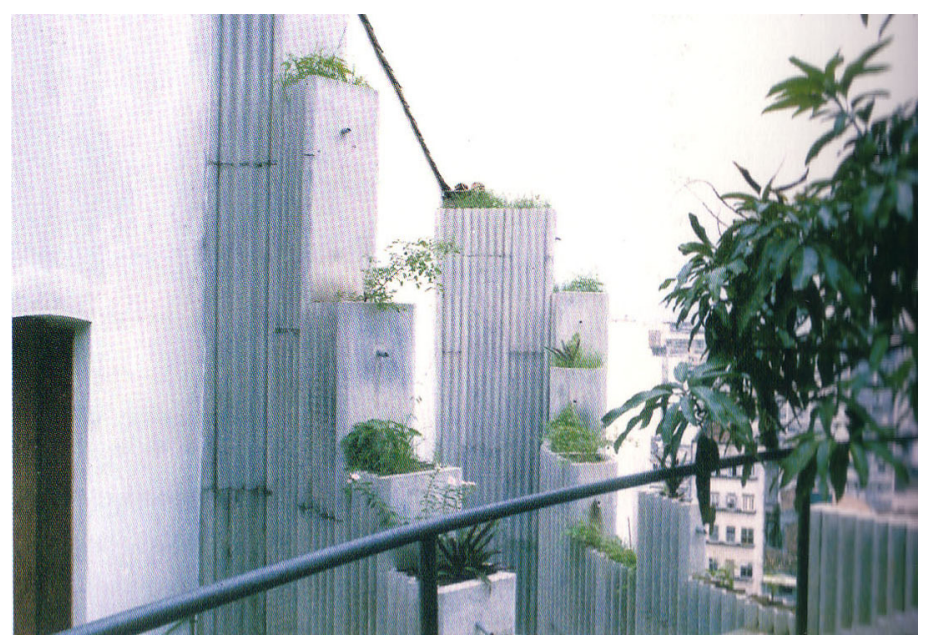
sistema através das amarrações das paredes e lajes pré-fabricadas. Algumas paredes recebem contrafortes de estabilização com estes painéis preenchidos com areia. Estas placas plissadas aparecem em todo o conjunto como uma espécie de amarração, dando a continuidade buscada para o casario colonial. Num outro momento, estas placas também consolidam a ruína existente. Depois, continuando a "fachada urbana", seguem livremente, revestindo-se de

Fig.41 Peças pré-fabricadas produzidas na Faec.

Fig.42 Montagem das peças in loco.

Fig.43 Contra-forte" feito com as peças pré-fabricadas consolidanso as paredes antigas. outras formas para a proposta de um edifício novo.

${ }^{67}$ CHAGAS, Maurício. Op. cit, pp.167-168. 


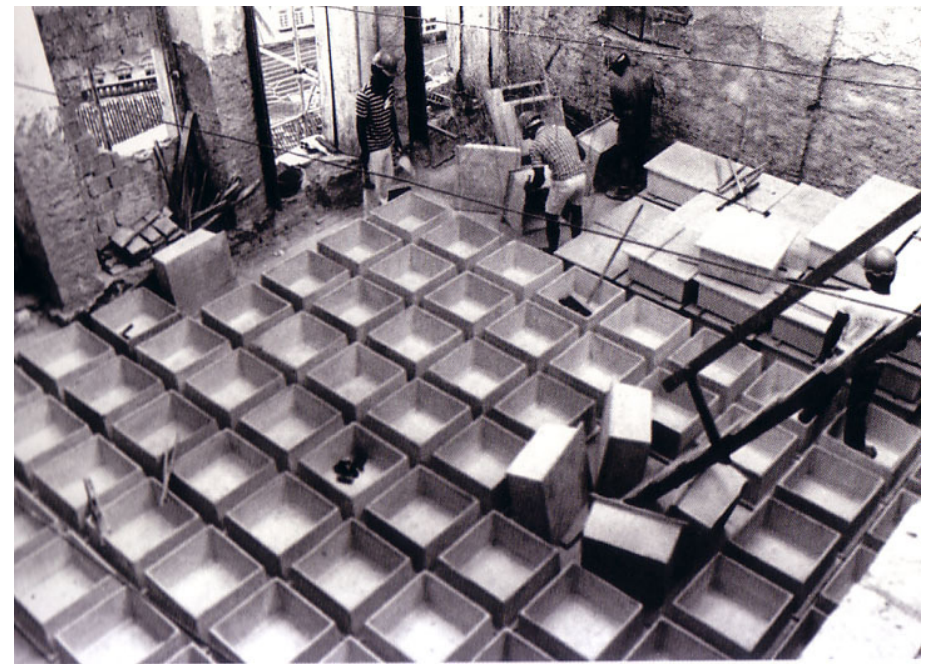

As lajes já prevêem a colocação de instalações hidráulicas e elétricas. Diferentemente da intervenção proposta na administração anterior para o Benin, a técnica construtiva do concreto - do nosso tempo - é empregada sobre o existente, no entanto permite ainda manter as mesmas características espaciais tradicionais. Os espaços constituídos novamente retomam plantas internas livres, espaços amplos. Contudo, para 0 uso habitacional os espaços são subdivididos posteriormente. Estas subdivisões são

Fig.44 Paginação e colocação das peças pré-fabricadas da laje. distinguíveis das paredes estruturais através da espessura muito menor e da altura diferenciada. Estas divisórias não têm a altura total do pé-direito, o que as distingue do restante do conjunto e também possibilita melhor iluminação e ventilação dos ambientes. A colocação destas divisórias deveria posicionar-se ortogonalmente às juntas dos pisos, o que implica num planejamento antecipado da combinação entre paginação das peças das lajes e as aberturas existentes das paredes antigas. 0 espaço criado permite a oferta de sete unidades de habitação e quatro áreas de comércio no térreo.

Segundo Marcelo Suzuki, em entrevista concedida para esta pesquisa, as janelas foram restauradas, no entanto, não há documentação do processo. 0 que se sabe é que se manteve o desenho e o ritmo existentes e as janelas são mantidas exatamente como foram encontradas. Os vidros antigos são mantidos quando possível e de acordo com a montagem da caixilharia já existente, onde a folha de vidro é colocada do lado externo do casarão. As portas e janelas são deixadas na madeira de lei aparente; apenas faz-se o tratamento em verniz naval incolor. As telhas são trocadas por outras do mesmo modelo capa-canal; rufos e calhas são adicionados para compor um sistema de drenagem mais eficiente. Estes elementos de drenagem são pintados de vermelho propositalmente, marcando a nova solução para a captação de águas pluviais. Todos os elementos de infra-estrutura propostos são aparentes. Quase tudo se torna aparente, mostrando o cerne, o funcionamento. Esta linguagem advinda inteiramente da arquitetura moderna é transferida para a intervenção sobre 0 antigo, no intuito de revelar as técnicas, os materiais, as possibilidades e os 


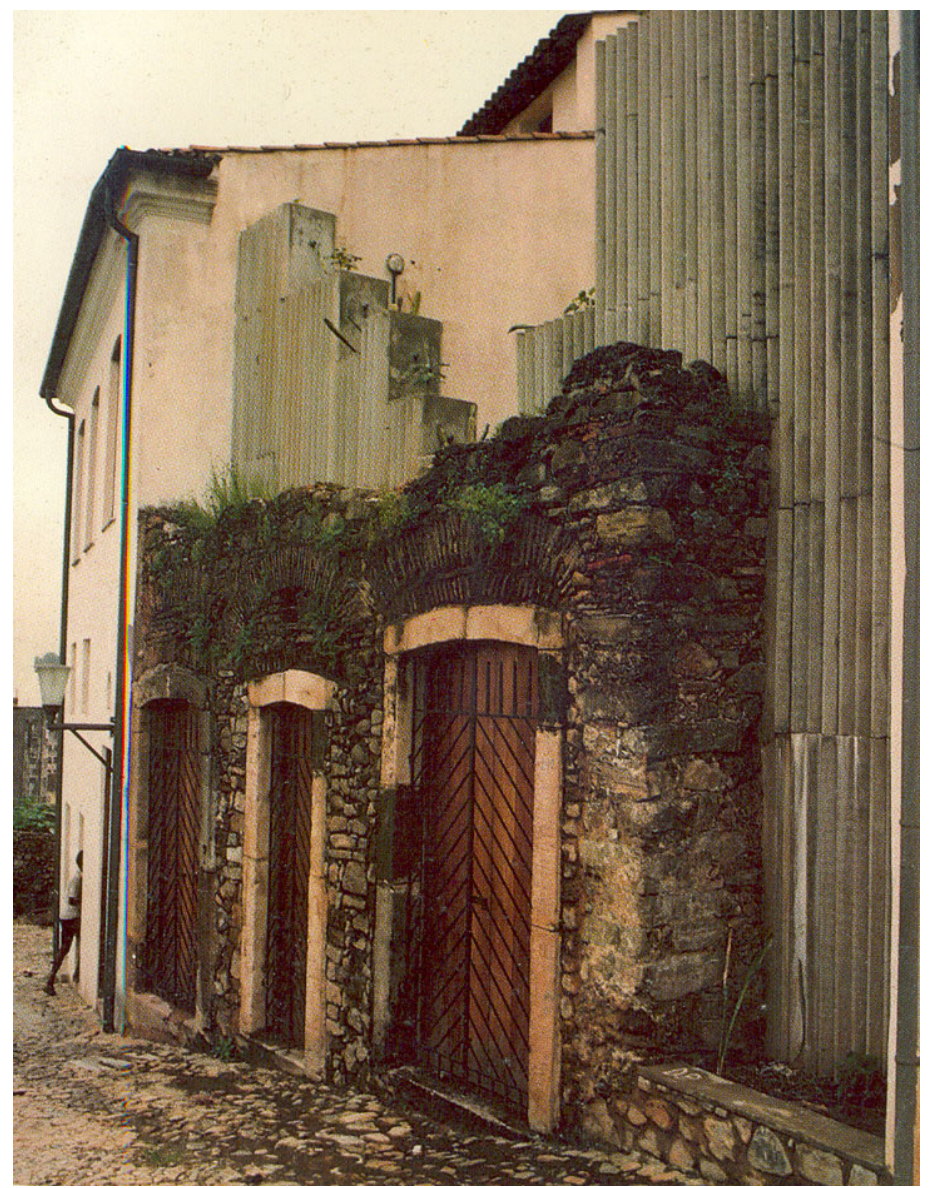

escamoteamentos. Lina não esconde nada, retira a superfície - às vezes necessária para a conservação de materiais. A convivência entre 0 antigo e o novo se faz de modo contrastante, mas harmônico. Este procedimento moderno na investida na honestidade dos materiais possibilita também a leitura rápida dos elementos estruturais e espaciais por qualquer cidadão. A diferenciação entre o que é antigo e 0 que é novo é simples e rápida. A vontade de não-intervir na parte antiga é aquela que também deseja revelar o tempo transcorrido, as cores manchadas, as modificações existentes e os modos de fazer. Por isto Lina procura fazer 0 mínimo necessário. 0 contraste com 0 novo, para ela, é a forma mais simples e educativa de leitura. Esta chave de leitura aproxima Lina das ações museológicas desenvolvidas na Itália e

Fig.45 Ruína consolidada. Bar dos 3 arcos. estão presentes também no MASP e no Solar do Unhão. ${ }^{68}$

As peças pré-fabricadas que compõem as escadas possibilitam uma enorme flexibilidade para as alturas dos espelhos. As peças da pisada são diretamente amarradas in loco na própria parede existente, sendo então ajustáveis apenas as alturas dos espelhos, dependendo das necessidades encontradas.

A ruína também é consolidada por placas plissadas. Para o uso deste edifício é proposto um bar, com o intuito de dar continuidade aos costumes já estabelecidos: bares de encontro da população local que costuma tomar doses de pinga e comer porções de caranguejo. O revestimento da ruína não é recuperado, ao contrário, a proposta é deixar a estrutura antiga aparente (a exemplo da Casa do Benin), contrastando com a técnica nova de consolidação. A laje construída define um terraço, uma superfície de contemplação do mar da

680 contraste também é uma metodologia usada para evidenciar o valor de antiguidade, conforme indica Alois Riegl. A leitura faz-se através da simples diferença, e por isso mesmo, é um procedimento que permite a leitura direta num primeiro contato, sendo, portanto, perceptível por qualquer pessoa, inclusive as menos instruídas. 


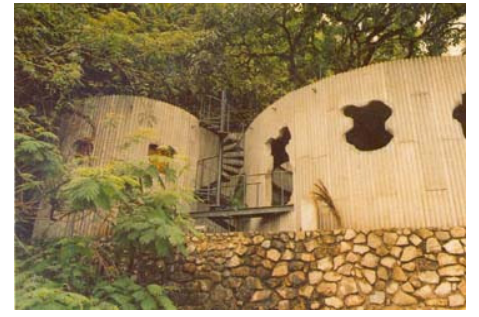

Fig.46 Restaurante Coaty. Uso das peças pliçadas de outra forma.
Baía de Todos os Santos.

O novo edifício, proposto no terreno baldio, é destinado ao Restaurante Coaty. $O$ desenho do espaço do restaurante foi delimitado pela presença da área verde ali existente, a qual em 1985 também é motivo da ampliação do tombamento do Centro Histórico. Dessa maneira, os taludes e o verde existente no local são também elementos referenciais desta "fachada da cidade" e praticamente definem a composição dos espaços do restaurante. As janelas seguem o padrão utilizado no novo edifício do SESC-Pompéia - são como buracos irregulares em pedras.

A desconfiança por parte dos técnicos da área de restauro e conservação local diz respeito à aplicação de um sistema estrutural industrial modular em contraste com a diversidade dos espaços existentes - construídos um a um. Estes edifícios, praticamente "moldados" no local, pertencem a um enorme repertório de tamanhos e prumos. Dessa forma, não se acredita na adequação de dois tipos distintos de sistemas estruturais, pois as perdas nestes "recortes" não seriam motivo de economia e sim de desperdícios. Também questionam a capacidade das fundações em absorver a sobrecarga das novas lajes.

Conforme indica Maurício,

"A tecnologia provou, contudo, ser bastante maleável e adaptável à diversidade [...] o elevado custo inicial de realização, devido à concentração do investimento necessário à elaboração do projeto, ao desenvolvimento e execução de formas metálicas de alta precisão, tenderia a ser diluído, a médio prazo, com a elevação da escala de produção das peças componentes do sistema." 69

\section{barroquinha}

A segunda área de intervenção, a Barroquinha, localiza-se no fim da Rua Chile, lugar onde se inicia uma ladeira importante de acesso entre cidade alta e cidade baixa e onde também há alguns indícios da existência de um baluarte de defesa da cidade de Salvador. Esta área é composta por diversas edificações com usos mais ligados aos encontros sociais. São três tipos de espaços de intervenção - edifícios existentes, terrenos ou vazios e ruas do entorno -, mas apenas parte da proposta é realizada.

\section{O projeto para a Igreja Nossa Senhora da Barroquinha bem como o seu}

\footnotetext{
${ }^{69}$ CHAGAS, Maurício. Op. cit, p.169.
} 
estacionamento não são realizados. Lina propõe um uso totalmente distinto para a Igreja assim como para o estacionamento. A Igreja que apresentava uma planta típica das matrizes da irmandade do começo do século XVIII da Bahia planta retangular com corredores laterais - deveria ter seu uso totalmente modificado pelo projeto de Lina. A proposta seria criar uma espécie de Centro Comunitário para esta Igreja que se apresentava totalmente em ruínas. Não foi encontrada, entre os documentos pesquisados, a justificativa da modificação radical do uso da Igreja. A Igreja encontrava-se totalmente destruída e a idéia era conceber 0 projeto considerando este estado arruinado, agregando-lhe soluções novas. Da mesma forma como havia sido feito no Bar dos 3 Arcos, na Ladeira da Misericórdia, o objetivo do projeto seria contrastar antigo e o novo deixando a ruína existente e adicionando elementos novos. 0 estacionamento da Igreja deveria abrigar a Feira de Ervas e ainda seria implantada a estrutura de apoio como banheiros e depósitos.

O Cine Glauber Rocha, o edifício antigo Cassino Tabaris, o Antigo Bar Cacique e o terreiro são projetos realizados. A ocupação do entorno seria a mesma do tecido geral: habitação nos pisos superiores e comércio local no térreo.

O Cine Glauber Rocha recebe uma nova fachada - projetada por Rogério Duarte -, inspirada no cartaz do filme "Deus e Diabo na Terra do Sol". Hoje, o cinema está sendo demolido. A falta de documentação e a impossibilidade de visitação dos edifícios executados contribuem para a análise menos apurada deste projeto.

olodum

A proposta para este casarão vem de iniciativa do grupo Olodum, uma organização que referencia a cultura negra em suas manifestações culturais, principalmente na música. O casarão da Rua Gregório de Mattos foi comprado em 1985 e estava totalmente deteriorado, restando apenas as paredes externas com as aberturas originais de portas e janelas. Algumas marcas evidenciavam as paredes internas do edifício, mas, no entanto, a documentação era bastante escassa.

Esta obra tem início em 1987, porém é, por várias vezes, interrompida, sendo retomada definitivamente em 1990, após a obtenção de recursos 


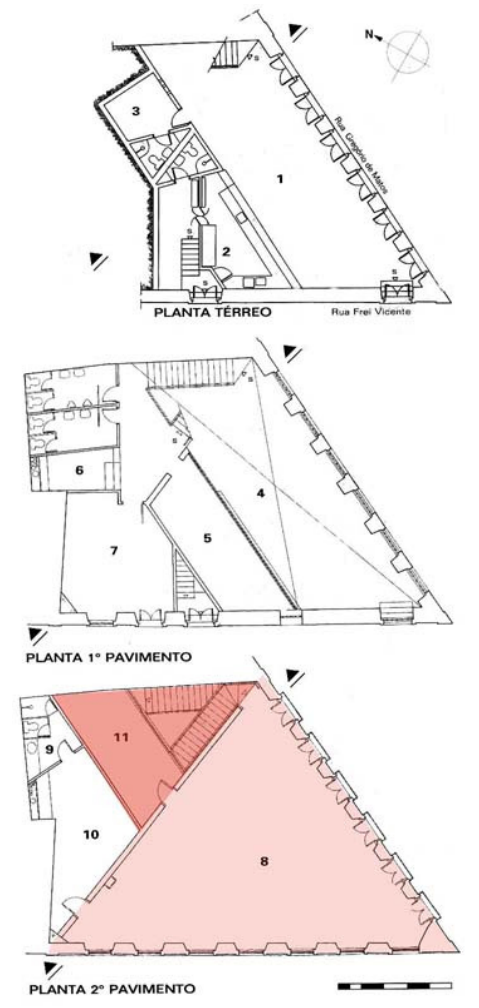

Fig.47 Planta da casa pertencente ao Olodum. Marcado pela autora da dissertação, em tons de vermelho, a triangulação da planta.

1.Bar; 2.Cozinha; 3.Portaria; 4.mesas; 5.Biblioteca; 6.Secretaria; 7.Depósito; 8.Sala; 9.Banheiro; 10.Hall; 11.Sala. financeiros para a sua execução. A exemplo da Ladeira da Misericórdia, os elementos estruturais de cimento armado produzidos na Faec são usados na amarração das paredes, na recuperação das lajes do segundo pavimento e na divisão dos ambientes. 0 pé direito alto do térreo proporciona a criação de um mezanino sob o bar proposto. 0 resultado espacial na proposição do mezanino é totalmente diferente daquele encontrado na Casa do Benin, na proposta da administração anterior. Apesar do uso da nova tecnologia construtiva, o sistema construtivo preexistente determina a solução no Olodum. A liberdade formal é condicionada por uma característica preexistente que deve ser preservada. Ambos os resultados de inserção do novo utilizam-se da técnica moderna e atual contrastando com 0 antigo. No entanto, a proposição de Lina para o edifício do Olodum é absolutamente harmônica, pois respeita a condição estrutural das paredes isostáticas do edifício antigo.

A planta totalmente irregular tem uma nova proposição. A nova divisão interna proposta tem a intenção de racionalizar os ambientes através de formas triangulares. A nova escada proposta, localizada num dos lados do edifício, inicia a organização da planta, definindo esta triangulação. Neste triângulo, definido pela circulação vertical, Lina propõe uma nova cobertura, como uma espécie de domus. Dessa forma, surge um triangulo que deixa entrar luz natural e marca a racionalização da planta.

As instalações elétricas são aparentes. Os elementos novos aparecem brutos, sem revestimentos. A fachada existente é pintada de branco, assim como nos outros projetos. Essa pintura alva acaba marcando inúmeras divergências entre os funcionários do Sphan local. Inicialmente, o serviço de proteção do patrimônio da cidade de Salvador é totalmente contrário a esta iniciativa. Alguns, ironicamente, sugerem que Lina queria transformar o Centro Histórico baiano numa espécie de "cidade mediterrânea" à beira mar. Outros, pertencentes à própria equipe de projeto, dizem que Lina queria apenas marcar uma intervenção através do branco contrastante do resto do tecido degradado. Inclusive, acreditam que, após a ocupação, a população poderia apropriar-se do edifício e pintar de qualquer forma a nova fachada, de acordo com o gosto de cada um. Pode-se dizer que esta é uma prática que ocorre hoje no edifício do Olodum, por exemplo. No entanto, não se acredita que a pintura proposta seja fruto de um descaso ou arbítrio, mas de uma proposta marcadamente incisiva sobre 0 

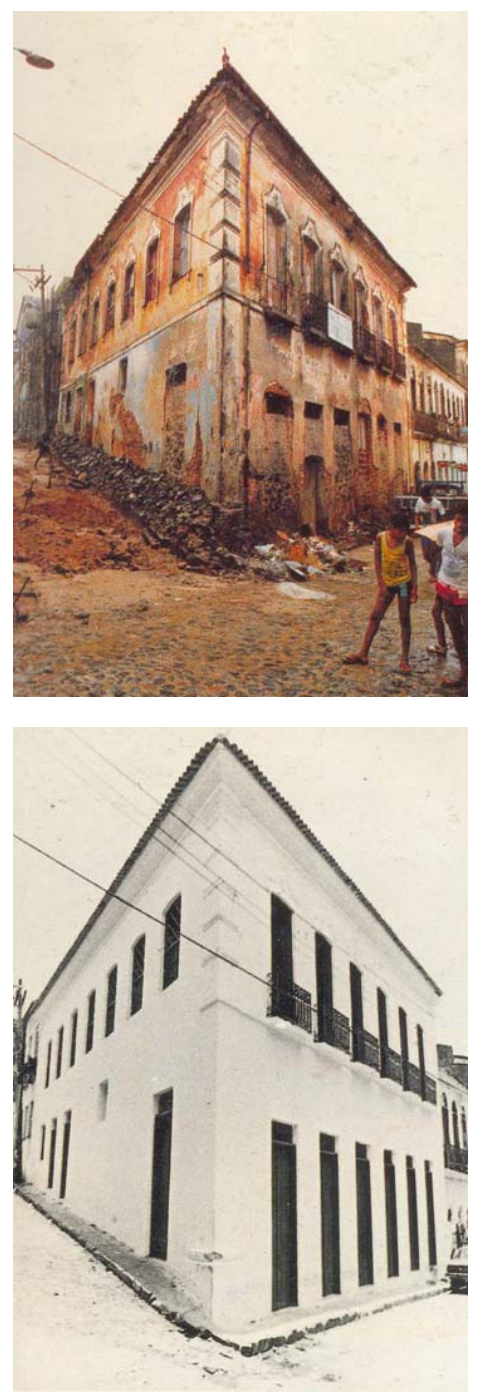

Fig.48 Estado da fachada em 1986 .

Fig.49 Fachada depois da intervenção de Lina. existente. 0 tratamento das superfícies, apesar do duvidoso rigor metodológico no processo e no uso de materiais adequados, não é uma proposição aleatória. Como foi colocado anteriormente, um dos elementos que merece atenção nos projetos é exatamente estas superfícies: a raspagem de algumas argamassas para revelar a técnica construtiva original, a pintura contrastante das janelas e portas, a superfície ondulada dos novos elementos somada a suas formas brutas e aparentes, da cor do próprio material. Como se percebe, a superfície é um elemento importante na leitura dos projetos e por isso não se pode admitir que a pintura branca proposta para os edifícios seja apenas fruto de uma atitude indecisa que seria apreciada num futuro próximo. Algumas indicações fornecem subsídios para a justificativa desta proposta.

Sabe-se que Lina não tinha intenção de retomar um estado original. Não há também, conforme as entrevistas realizadas com alguns integrantes da equipe, a proposta de se fazer uma prospecção detalhada das diversas estratificações. Esta opção é, de início, descartada, conforme narram alguns integrantes da equipe, pois o estado de degradação estava bastante avançado. Além disso, pensar numa ação prospectiva para o conjunto demandaria tempo e dinheiro e provavelmente não resolveria o problema, uma vez que cada edifício corresponderia a uma estratificação diversa. Retomar as cores originais não corresponderia nunca à percepção do conjunto. Seria repetir uma idealização já conhecida através da metodologia usada pelo Sphan. Deixar a pátina e as marcas do tempo seria um caminho pertinente, conforme as outras intervenções de Lina e a vontade de revelar sempre o antigo em convívio com o novo. No entanto, novamente, esbarra-se na condição degenerativa incidente no conjunto. Distinguir a pátina - marca positiva do edifício - das patologias e sujeiras marcas negativas - seria também algo desconsiderado pelos mesmos motivos da negação à prospecção mais detalhada do projeto. Mudar a imagem que 0 conjunto consolidara com o tempo seria, portanto, um caminho inevitável. A única opção que resta então é a proposição de algo novo para as superfícies do conjunto. Escolher ao léu, livremente, cores distintas para cada edifício também seria oposto ao que Lina preconizava sobre o exame crítico necessário em qualquer ato de intervenção. Neste sentido, a opção pelo gosto pessoal de cada morador é algo a ser desconsiderado também. A escolha do branco pode ser então entendida como uma ação crítica proposital, advinda da vontade artística 
de sua geração moderna. Não é uma interpretação do que deveria ser, mas uma proposta com o sentido de ato criativo e novo. Neste momento a estratificação valorizada é o próprio presente, pois a pintura monocromática coloca tudo sob 0 mesmo plano atual.

Esta hipótese sugere um posicionamento crítico em relação à inserção do novo através do contraste com o antigo. No entanto, há que se considerar que os procedimentos que envolvem um projeto de restauração no tratamento das superfícies são mais criteriosos. Não são conhecidos detalhes sobre as camadas de superfícies que, ao longo do tempo, foram sendo adicionadas a estes projetos, não se sabe que tipo de tinta foi empregada e se realmente seria a mais adequada para este tipo de alvenaria. ${ }^{70}$ Para isso tampouco são estabelecidos estudos aprofundados ou mesmo um grupo de profissionais especializados que direcione a solução para uma alternativa mais adequada.

O mobiliário também foi detalhado por Lina e equipe. Seu desenho é racional e simples. A maior parte é feita em madeira e o material define as formas das articulações e tipos de encaixe.

O projeto encontra-se hoje acrescido de uma série de modificações, principalmente com o uso exacerbado de tipos de revestimentos como texturas, cores vibrantes, pedras almofadadas.

processo metodológico

Algumas observações devem ser levadas em conta sobre o processo metodológico da arquiteta, desde a análise, os desenhos propostos até a execução da obra. Acredita-se que a partir do procedimento de Lina, principalmente no diálogo estabelecido entre o antigo e o novo, é possível entender as diferentes formas de abordagem tanto em relação a um projeto de restauro como à idéia de projeto moderno.

No material de análise é possível evidenciar a busca constante da "vocação do lugar"71. Este procedimento de leitura mostra algumas

\footnotetext{
${ }^{70}$ Sobre este assunto destaca-se KÜHL, Betriz Mugayar. 0 tratamento das superfícies arquitetônicas como problema teórico da restauração. Anais do Museu Paulista, v.2, jan/dez 2004, p.309-330.

${ }^{71} \mathrm{~A}$ leitura do contexto urbano onde o projeto se insere é um procedimento alinhado aos arquitetos do pós-guerra, principalmente àqueles participantes do Team X. "O problema do contexto foi uma questão recorrente entre os arquitetos modernos italianos desde os anos 40. Importava para eles desenvolver uma reflexão sobre a inserção da linguagem moderna em um entorno composto de
} 
particularidades na metodologia adotada pela arquiteta. Os desenhos de análise já demonstram o espírito, a ambientação do lugar. Os desenhos não têm precisão necessária para 0 detalhamento do projeto de restauro. São levantamentos proporcionados por aquarelas livres, narrativas. A aquarela feita por Lina mostra fachadas contínuas de casarões coloniais que parecem apenas auto sustentar-se. No ritmo das janelas de arco pleno intercalam-se imagens de pássaros voando no azul do céu e pessoas debruçadas nos balcões: configuram-se imagens de ruínas e fachadas soltas. Lina desenha como se contasse a história do momento de sua visita ao lugar, pois as pessoas parecem olhar desconfiadas para ela, algumas inclusive escondendo-se. As casas têm cores amarelas, velhas, e ora aparecem verdes fortes sobre os telhados. Plantas vivas nascem das paredes. As mais variadas atividades acontecem na rua: pessoas sentadas, vendendo coisas, crianças brincando, cachorros, pessoas apressadas. Outro documento de análise, as fotos enviadas pela prefeitura, mostram exatamente a dinâmica existente no local. No pavimento superior de um sobrado, uma mulher trabalha em seus afazeres domésticos, esticando roupas no varal improvisado entre os batentes das janelas da fachada e nos balcões. Na parte térrea há um comércio local - a "Quitanda Laura" recebe mercadorias. As crianças estão sempre presentes nas imagens de levantamento, brincando, sentadas nas soleiras, nas calçadas. Ficam visíveis também nas fotos encomendadas para a equipe de levantamento da prefeitura de Salvador as questões técnicas enfrentadas, além das ruínas em evidência. Infiltrações importantes, desmoronamento dos rebocos, estruturas aparentes, ferros enferrujados, coberturas danificadas, madeiras em deterioração, vidros quebrados, remoção de alguns elementos decorativos além das adições de divisórias improvisadas nas áreas internas. No entanto, este levantamento dos aspectos técnicos dos edifícios e seu estado de degradação nunca aparecem isolados, mas sempre animados por acontecimentos cotidianos, na tentativa de documentar a situação completa do lugar, nos seus aspectos materiais e sociais, ou ainda, na forma como está sendo apropriado e vivido pelos habitantes locais.

edifícios antigos, monumentos históricos que guardavam a identidade do povo italiano e passagens de períodos importantes da história da civilização ocidental. 0 valor atribuído aos centros históricos, por um lado, e a crença na arquitetura moderna como solução para os problemas de espaço na sociedade contemporânea, por outro, levaram os arquitetos italianos a um dilema entre a tradição e o novo. Ernesto Rogers foi um dos primeiros a procurar uma síntese para essa oposição através do projeto da Torre Velasca." BARONE, Ana Claudia. Op. cit., p. 155. 
Esta observação detalhada é fundamental para se propor uma nova destinação para o lugar e, neste sentido, o uso é pensado como instrumento fundamental para a salvaguarda do conjunto, de modo a conduzi-lo da melhor forma para

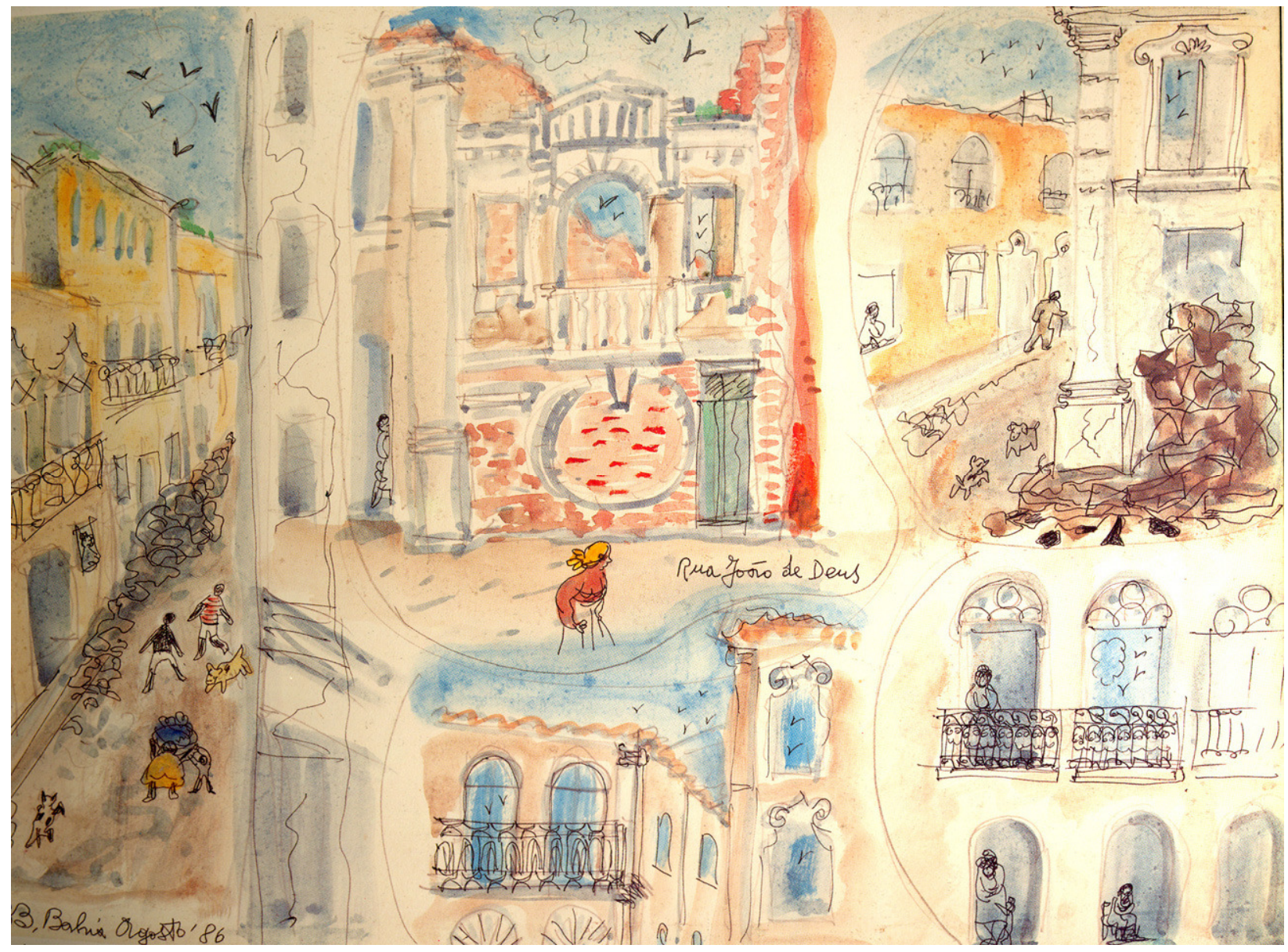

uma adequada inserção no tempo presente. 72

Assim, a questão do uso participa de forma orgânica e concomitante de todo o processo, constituindo elemento fundamental na definição do programa que embasa a nova proposta. Este procedimento é fundamental para entender a concepção de projeto proposto por Lina, pois a aceitação deste princípio tem reverberações em todo o trabalho. A consideração da situação do presente repercute de forma incisiva no projeto de criação, funcionando da mesma forma que os limites normativos ou naturais. Sua percepção individual é tomada também em consideração e torna-se marca do processo criativo.

A memória individual da própria arquiteta torna-se coletiva no momento em que ela registra os fatos rotineiros em seus desenhos ou material de análise.

72 BARDI, Lina. Ladeira..., op.cit. 

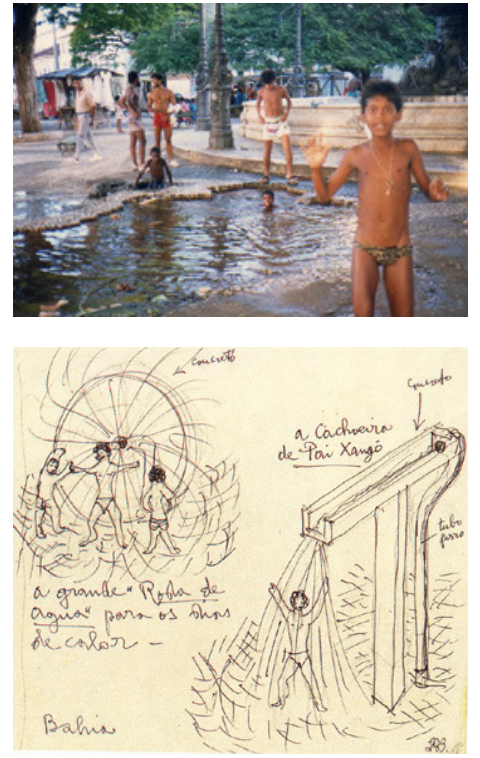

Fig.51 Foto de levantamento.

Fig.52 Desenhos de Lina para Roda D'água e Cachoeira.
Sua própria trajetória individual é considerada também: aquele que vê, interpreta, qualifica. ${ }^{73}$ É desta forma que se considera também a entrada da questão da participação popular no processo: através do filtro da sua sensibilidade para considerar as realidades encontradas durante o processo; na referência aos usos existentes, às formas de fazer; no repertório formal para a criação do novo retirado da cultura popular. Ou seja, o intuito democrático durante a seleção e a representação da identidade do cidadão comum concretiza-se no procedimento, pois Lina torna a realidade encontrada intrínseca à nova proposta. Um exemplo significativo é o registro do vazamento de uma adutora de água na Praça da Sé. O acidente momentâneo é apropriado como "brincadeira" por algumas crianças que ali estão e assim um simples vazamento transforma-se numa grande e divertida piscina. Este espaço de lazer "efêmero" construído pelas crianças é documentado e incorporado na construção do novo programa para aquele lugar, que, com características de um país tropical, solicita o uso da água para que as pessoas se refresquem, e naquele acontecimento efêmero, registrado pela equipe, estava a sugestão e a prova de que isto poderia funcionar. Lina parece recuperar o "incidente", não como catástrofe da infra-estrutura, mas como espontaneidade capaz de se integrar e contribuir na construção do programa, ${ }^{74}$ como atividade lúdica. Este acontecimento se materializa arquitetonicamente na proposta da Roda D'água e na Cachoeira do Pai Xangô. Esta interpretação torna-se plausível uma vez que o processo de criação adotado pela arquiteta parte da observação de situações locais, de materiais e de usos que são incorporados na construção do programa como condicionante da forma final. 0

${ }^{73}$ Essa marca individual colocada no processo acontece também na execução dos projetos. Nas entrevistas com Marcelo Suzuki e Marcelo Ferraz isso fica evidente. Um erro na execução durante a obra é sempre colocado em evidência ao invés de tentar reverter a situação. "Pinta-se de vermelho", pois também fez parte do processo, da história da obra.

${ }^{74}$ Sobre o programa, ver ANELLI, Renato. Interlocução..., op.cit., p. 80. 0 programa não é uma lista de atividades que a forma deve permitir, mas é parte fundamental do "processo de concepção". Renato afirma na página 81: "inserida a obra de Lina Bo na linha de Ponti e Rudofsky significa considerar sua atividade cenográfica no teatro não como um mero exercício interlinguagens como muitas vezes se insiste em interpretar, mas como fato essencial para a constituição da sua poética arquitetônica. Dessa raiz comum, Lina Bo se aproxima mais da concepção de Rudofsky com seus questionamentos à erudição vazia da cultura abstrata e sua aproximação à simplicidade vital das culturas populares ou não-européias. Mas a valorização das artes decorativas, defendidas por Ponti ao longo de sua carreira, matiza o rigor ético e político da ação de Lina Bo e sua defesa por um design originado da cultura popular. Uma fantasia que Lina encontraria nos objetos utilitários e brinquedos populares reunidos na exposição $A$ mão do povo brasileiro, onde a sucata se transformou em singelas peças figurativas." Ver também: BARDI, Lina Bo. Contribuição..., op.cit.

${ }^{74}$ FERRAZ, Marcelo. Lina..., op. cit. Olívia fala do lado místico da cachoeira nos projetos de Lina. OLIVEIRA, Olívia F. Sutis..., op.cit., p.161. 
desenho não parte, portanto, de referências formais universais abstratas dadas a priori, mas é engendrado paulatinamente no processo de reconhecimento do local da intervenção. O mesmo procedimento projetual é facilmente apontado por ela mesma na concepção do SESC-Pompéia:

“(...) na segunda vez que estive lá, um sábado, o ambiente era outro (...) crianças corriam, jovens jogavam futebol debaixo da chuva que caía dos telhados rachados, rindo com os chutes da bola na água. As mães preparavam os churrasquinhos e sanduíches na entrada da rua Clélia; Pensei: isto tudo deve continuar assim, com toda esta alegria." ${ }^{75}$

$O$ desenho do mobiliário também tem uma referência distinta daquela apenas fornecida pelo raciocínio de composição ou decorrente de uma solução estrutural, pois parte da referência direta a objetos populares locais existentes. A mesa do Belvedere da Sé mostra esta questão. A referência para o desenho da mesa de concreto é um "Caxixi", cerâmica popular do Recôncavo Baiano que serve como brinquedo infantil. $O$ desenho segue a simplicidade da forma cilíndrica achatada nas duas pontas, formando bases planas nas extremidades. $\mathrm{O}$ apoio da peça é uma dessas bases, simples e pesado o suficiente para ser usado como pés de mesas que necessitam ser estáticas (pois são colocadas em áreas urbanas externas). 0 processo de fabricação manual do objeto popular no seu modo de fazer é incorporado ao processo de pré-fabricação em ferrocimento. Não há romantismo no trato com a herança, nem saudosismo com o passado. A forma é reinterpretada e transformada em fonte de inspiração para os processos de fabricação atual do mobiliário urbano. Transforma-se, conservando a sua poética econômica e mísera, qualificando o passado com a vida presente. Antigo e novo se complementam e convivem. 0 processo do design do mobiliário pressupõe o "presente histórico" assim como todas as suas ações. Mais uma vez, este procedimento aproxima Lina dos movimentos que procuram superar a concepção acadêmica das formas e padrões preestabelecidos e da busca de elementos da realidade cotidiana como fonte de referência, como continuidade de uma cultura autêntica.

O caráter histórico que predomina no interesse do Centro Histórico como testemunho de uma cultura urbana surge principalmente na conservação da estrutura do tecido: no respeito aos cheios e vazios, na manutenção das estruturas viárias e dos elementos naturais que constituem aquele ambiente

75 Idem, ibidem. 
(singularidade geo-morfológica); na conservação da estrutura dos quarteirões e na proposição dos usos adequados ao lugar. Lina, neste sentido, tem uma proposta bastante incidente ao que concerne à reestruturação urbanística, ou seja, uma proposta que leva em conta a relação entre o centro histórico e território no seu aspecto funcional. Mantém principalmente a estrutura existente: habitação nos pisos superiores e pequenos comércios no térreo. A memória local é o que se quer preservar apesar das atualizações pretendidas e as inovações não devem romper com as relações e características da situação existente.

O que mais chama a atenção enquanto respeito ao caráter histórico da estrutura urbana fica evidente principalmente no trato com a estrutura dos quarteirões. Diferentemente de propostas contemporâneas, os quintais em nenhum momento são abertos como "praças públicas", mas respeita-se este vazio sob seu aspecto tipológico como "quintal interno". A estrutura contínua das fachadas e a relação dos edifícios com a rua são mantidas o quanto possível. Exceções ocorrem quando há a total impossibilidade de restauração do edifício devido ao grau de deterioração apresentado naquele momento. Neste aspecto, Lina nunca permite a falsificação, a repristinação ou qualquer ato presente que tente imitar o passado. É desta forma que Lina também se distancia da proposta de Zevi ou mesmo daquelas decorrentes da nossa própria história de tutela em conjuntos urbanos. A proposta da arquiteta é sempre, em qualquer momento, declarada, explícita como pertencente a sua própria época. Há sempre uma harmonia exposta entre o presente e o passado atingida através da dissonância.

A Casa do Benin também é um exemplo onde isso acontece. Há uma praça ao lado da continuidade do casario. Nesta lacuna não se tenta criar algo que poderia ser então aquela forma original. Lina também não tenta resgatar uma imagem figurativa da estrutura passada, mas sim aquilo que permaneceu até o momento presente. Deve-se considerar que o estado de degradação do Centro Histórico de Salvador não se deu por uma catástrofe (acidentes, bombardeios ou guerras), mas foi decorrente da ação lenta do tempo. Refazer uma lacuna, conforme as indicações promovidas pelo Sphan no caso de Ouro Preto, por exemplo, seria ignorar este fato preexistente. Preserva-se assim uma espécie de praça, destituída de área verde, mas com equipamentos de serviço, como banheiro público, por exemplo. A praça é árida e construída. 
Mesmo na inserção de edifícios novos, o resultado é muito similar à estrutura encontrada no momento do levantamento, da presença da arquiteta no local. O tratamento das lacunas na Ladeira da Misericórdia é bastante elucidativo. Os elementos novos construídos diferenciam-se totalmente do conjunto antigo não só através da técnica construtiva, mas através da cor, forma e textura. No entanto, a cor do concreto é bastante semelhante ao muro de arrimo do fundo, além de contar com a presença importante de plantas na constituição destas fachadas, dando continuidade ao aspecto da paisagem (arrimo de pedra - talude verde). A implantação destes projetos na Ladeira da Misericórdia necessita de uma sensibilidade bastante aguçada, uma vez que 0 elemento mais importante nesta "fachada da cidade" é exatamente o "buraco" existente na malha urbana do Belvedere da Sé, localizada acima desta intervenção. Esta morfologia contínua constituída pelo casario e, logo, a interrupção neste ponto são significativas na estrutura histórica da cidade porque se configura um quadrado de entrada e saída da cidade, de defesa e ataque, de comunicação Novo-Velho Mundo. Portanto, a atenção para este fato histórico ainda se estabelece sem nenhuma interferência na inserção de uma nova arquitetura. Acredita-se que esta harmonia com a arquitetura moderna é fundamental neste lugar. Novamente, a arquitetura de Lina pressupõe a cidade através de uma leitura histórica-crítica ampla e consciente.

A estrutura usada nesta intervenção é praticamente a síntese desta preocupação e pode esclarecer alguns pontos importantes da análise. O sistema de peças pré-fabricadas desenvolvidas pelo arquiteto João Filgueiras Lima, o Lelé, tem uma concepção bastante racional no processo de fabricação ${ }^{76}$, mas dialoga também com o repertório formal deste lugar, analisado anteriormente. A concepção da estrutura parte de uma folha vegetal plissada, algo similar ao curculigo, um tipo de folha que tem uma estrutura plissada. A vontade da harmonia desta intervenção aparece já de início na concepção estrutural, na vontade de ser similar e de dar continuidade à vocação de "talude verde". As peças são usadas por necessidade de consolidação tanto das paredes externas como da ruína existente. A solução é bastante funcional: são colocadas de forma escalonadas e mantém 0 aspecto da sua função de contrafortes. São estes contrafortes externos que possuem no seu interior jardineiras que permitem 0

${ }^{76}$ BARDI, Lina Bo. Ladeira..., Op.cit., p.48 
crescimento de plantas. Mostra-se explicitamente a consolidação das estruturas antigas através do uso de novos materiais e de novas técnicas. Esta estrutura tem uma espécie de "costura" entre as placas de modo que o sistema fique monolítico, característica que permite dialogar com o funcionamento das paredes antigas de pedra da edificação. Esta intervenção, necessária para a conservação dos edifícios antigos, não falseia as estruturas antigas (apesar de ter o mesmo funcionamento monolítico), ao contrário, mostra-se moderna, eficiente e racional. As mesmas peças são usadas no interior dos edifícios para a solidificação das paredes internas. A forma plissada permite a obtenção de vazios nas paredes internas que possibilitam a passagem da rede hidráulica, o que possibilita a adequação do edifício para o uso da habitação. Este sistema permite a mais variada gama de formas e aberturas, liberdade mostrada no projeto do restaurante no final deste conjunto. As aberturas usadas neste restaurante permitem uma outra relação com os ritmos exatos das fachadas da edilícia antiga. São mais próximas de buracos de pedras irregulares que afloram por entre 0 verde das plantas.

$\mathrm{Na}$ apresentação do projeto da Ladeira da Misericórdia, Lina faz algumas considerações sobre seu procedimento. Primeiro chama o processo usado como recuperação. Este termo é a tentativa de diferenciar o procedimento habitual no projeto daquele instituído pela prática de restauração no Brasil. 0 significado de restauração é restrito à restituição de um estado primitivo de tempo, de lugar e de estilo. Apesar do reconhecimento da atualização da Carta de Veneza sobre os processos de restauração, Lina evidencia que pouco se modificou na prática no país, constatando o seu procedimento de "retorno" ao estado original e com forte apelo estético.

Ao que parece, Lina mostra-se atualizada em relação às discussões e à modificação da Teoria da Restauração. No entanto, os resultados obtidos podem ser considerados como sua interpretação da Carta de Veneza e, principalmente, como desdobramento das questões tratadas no decorrer do texto a propósito da sua visão de arquitetura moderna e a relação que esta estabelece entre 0 antigo e o novo. 0 conhecimento sobre a Teoria da Restauração é colocado muitas vezes por ela de forma bastante genérica ('princípios da restauração histórica tradicional'). 0 que parece ficar evidente é que a arquiteta utiliza-se basicamente de dois argumentos no projeto para o Centro Histórico: não abdicar da proposta 
como ação presente e respeitar a estrutura existente (morfológica e de uso), conforme indica:

"O que estamos procurando na recuperação do Centro Histórico da Bahia é justamente um marco moderno, respeitando rigorosamente os princípios da restauração tradicional. Para isso, pensamos num sistema de recuperação que deixe perfeitamente intacto 0 aspecto não somente exterior, mas também 0 espírito, a alma interna de cada edifício." 77

A diferença entre o processo da arquiteta e os procedimentos implícitos na restauração ficam evidentes se se pensa na metodologia adotada durante 0 projeto de recuperação. Como já foi colocado, a arquiteta não tem nenhuma sistematização pormenorizada do trabalho de acordo com as indicações da disciplina do restauro. Lina é uma arquiteta moderna que olha para o existente, 0 que não significa ignorar alguns métodos usados na prática da restauração. As questões inerentes à vocação do lugar percebidas no uso cotidiano são essencialmente o que determinam o projeto.

As contradições entre discurso e proposta existem em muitos exemplos se se considera como leitura a metodologia da disciplina da restauração, principalmente, em relação aos aspectos conservativos da edilícia antiga. Entretanto, há que se levar em conta as ações apresentadas. Como arquiteta moderna da segunda geração, Lina consegue estabelecer, através da leitura da preexistência e da visão crítica da história, fortes vínculos com a política cultural da época. Sua ação parece materializar o que o próprio Sphan preconizava na revisão das categorias culturais e do entendimento de patrimônio, cultura e, principalmente, na revisão da noção de tempo (continuidade) e de objeto (bem cultural). Há visivelmente uma defasagem entre o processo de definição destas categorias e a atuação do órgão de preservação. As ações promovidas pelo Sphan ainda são presas à imagem estética original, são restritas ao tombamento ${ }^{78}$ de grandes monumentos símbolos de uma nação homogênea, branca, elitista e muito distante da representatividade de uma sociedade plural. Lina trabalha em paralelo ao tom oficial - inclusive alheia ao instrumento do tombamento -, mas não por isso o seu procedimento sobre a cidade existente deixa de ser relevante. Apesar de sua posição marginal - no sentido de periférica

\footnotetext{
77 Idem, p.50.

${ }^{78}$ Alguns projetos foram tombados posteriormente à sua intervenção, portanto, intui-se que Lina consegue com a atribuição de um novo sentido ao edifício, através de uma metodologia própria, evidenciar também o seu valor histórico, ou melhor, o seu valor como objeto mnemônico em seu sentido pleno. O Sesc Pompéia, como já dito, é um exemplo significativo dessa compreensão.
} 
ao tom oficial ou das classificações acadêmicas -, seu trabalho aparece à luz de uma clara coerência entre discurso e prática, tendo assim todo o mérito de valorização e atenção. 


\section{concurso público: vale do anhangabaú}

antecedentes

O segundo objeto empírico analisado nesta dissertação é a proposta da arquiteta Lina e equipe ${ }^{79}$ para o Vale do Anhangabaú, realizada a partir de um concurso público. Cabe aqui destacar alguns momentos em que o Vale do Anhangabaú é considerado um tema de discussão e de que forma este objeto empírico é tratado.

O Vale do Anhangabaú é um elemento significativo na paisagem urbana da cidade de São Paulo, porque condiciona a implantação da cidade de modo bastante particular. O Vale do Anhangabaú somado ao Vale do Tamanduateí conformam os limites da colina central da cidade, local escolhido para a fundação da capital paulista. $\mathrm{O}$ traçado sinuoso das primeiras ruas no planalto $\mathrm{e}$ a localização do núcleo original "entre vales" determinam uma situação particular de implantação, como uma combinação da herança da tradição portuguesa e as condicionantes locais existentes, principalmente, os limites topográficos impostos e a técnica local disponível para a edificação, a taipa-de-pilão.

A situação topográfica do Vale do Anhangabaú interfere no crescimento da cidade, separando, num certo momento, distintamente, o "centro velho" e 0 "centro novo". É dessa forma que o Vale do Anhangabaú configura-se como "limite" da ocupação urbana, como elemento topográfico e ambiental que caracteriza e condiciona de forma particular o modo de ocupação da cidade. Esse elemento, portanto, tem significado importante na inteligibilidade do sítio urbano e, por assim dizer, configura-se como bem cultural do patrimônio da cidade de São Paulo. No entanto, este traço particular da configuração urbana que poderia ser usado como um dado positivo da paisagem é pouco considerado durante 0 desenvolvimento da cidade. A exemplo dos rios da cidade de São Paulo, os vales e pontos privilegiados do traçado geográfico da cidade não são considerados elementos de apreciação cultural no decorrer do seu desenvolvimento urbano. Observa-se que o Vale do Anhangabaú passa a merecer atenção em função de outros aspectos, principalmente a partir do

\footnotetext{
${ }^{79}$ A equipe é composta por Francisco Fanucci, André Vainer, Lina Bo Bardi, Marcelo Ferraz, Paulo Feracotta, Guilherme Paoliello, Bel Paoliello, Marcelo Suzuki e Uchoa Carvalho.
} 
momento em que passa a ser considerado um obstáculo para o crescimento da cidade, ou seja, enquanto barreira natural que deve ser transformada em prol de um benefício funcional, como, por exemplo, viabilizar as vias de fluxos de transportes. É dessa forma que a análise deste elemento urbano aqui investigado acaba sendo desenvolvida através de outro viés disciplinar. O Vale do Anhangabaú, por volta da primeira década do século XX, é palco das primeiras intervenções urbanas na cidade e, porque não dizer, pretexto para as primeiras discussões sobre a disciplina do urbanismo no Brasil.

No fim do século XIX, a cidade colonial começa a ser destruída e substituída. Transformações na economia, na sociedade, na cultura e na forma de viver são decorrentes, neste momento, de uma série de fatores, como o êxito da cultura cafeeira no oeste paulista, a abolição da escravatura, o aparecimento do trabalho livre, os novos trabalhadores imigrantes europeus, o início de um pólo de distribuição de comércio e serviços. 0 acelerado surto econômico e 0 clima de euforia financeira modificam uma série de costumes, o que se reflete diretamente na configuração da cidade. "Uma série de carências caracterizava a cidade neste período além da circulação: as moradias eram insuficientes, os cortiços se multiplicavam, o abastecimento de água era deficitário, o desvio de águas servidas inexistente."80 A clara inadequação do núcleo colonial aos interesses econômicos e sociais da elite abastada, administradora da cidade, provoca a necessidade de transformação sob a ótica das preocupações desta classe dominante. A salubridade, a circulação e o embelezamento constituem a tríade de fundamentos dos pensamentos da ação urbana neste período. Procura-se uma modernização do ambiente urbano, sempre aos moldes europeus. No período entre 1898 e 1910, o prefeito Antonio da Silva Prado empenha-se em transformar ao menos o centro de São Paulo numa cidade européia.

"Suas preocupações com a estética da cidade, onde os padrões de beleza eram europeus, deixaram marca na área central por algumas décadas. Nesse período foi construído o Teatro Municipal, mostrando que a cidade possuía uma casa de espetáculos de nível europeu, capaz de abrigar espetáculos de nivel cultural"s1

80 SAMPAIO, Maria Ruth Amaral. A gênese do urbanismo: o caso de São Paulo. In: MACHADO, Denise Barcelos Pinheiro; PEREIRA, Margareth da Silva; SILVA, Rachel Coutinho (org.). Urbanismo em questão. Rio de Janeiro: UFRJ/PROURB, pp.127-144, 2003.

81 Idem, p.136. 
Conforme José Geraldo Simões, até este momento o vale tinha o seguinte aspecto: " $O$ vale que separava a velha cidade da nova, apresentava até 1910 um aspecto semi-rural, sendo cruzado pelo ribeirão Anhangabaú e contendo ainda vestígios de antigas chácaras, e era para onde se voltavam os fundos das casas das ruas Formosa e Líbero Badaró." ${ }^{2}$ Desde a fundação de São Paulo, a estrutura central da cidade havia consolidado o lado oposto, em direção às ladeiras do Carmo e da Glória, voltadas para o Vale do Tamanduateí, como "entrada principal" da cidade para quem vinha de outras importantes localidades, como Santos ou Rio de Janeiro. Com a implantação da ferrovia no fim do século XIX e com o desenvolvimento dos novos bairros no lado oeste e a construção do Viaduto do Chá, o foco passa a ser o lado oeste da colina central, onde se localiza o Vale do Anhangabaú. A partir deste momento, o vale passa a ser palco de inúmeras discussões urbanísticas.

O primeiro foco de atenção parte de um grupo composto por representantes da sociedade paulista, como fazendeiros, capitalistas, comerciantes, profissionais liberais, auxiliados por Alexandre de Albuquerque, professor da Escola Politécnica. Este grupo solicita a abertura de três grandes avenidas "a exemplo do que se tem feito nas grandes e mais adiantadas cidades"83.

Outras iniciativas também entram em pauta, como as propostas sugeridas pelo vereador Silva Telles em 1906, detalhadas por Victor da Silva Freire $^{84}$. Depois de divergências em relação à desapropriação de alguns edifícios para consolidar a área como "parque público", Victor Freire e o engenheiro Eugenio Guilhem apresentam outra proposta, reformulando o sistema viário da colina central. Como aporte teórico, Victor Freire faz referência a duas concepções (consideradas antagônicas por alguns autores): a do vienense Camillo Sitte e Mulford Robison.

"A combinação harmoniosa entre o espaço construído e o espaço livre orienta o traço de Victor Freire na sua proposta de um anel viário na área central de São Paulo: a elegância do traçado curvilíneo das ruas, largas para permitir a fácil circulação, e dilatadas em pontos estratégicos, de forma a configurar uma

82 SIMÕES, José Geraldo. Anhangabaú: história e urbanismo. São Paulo: Editora Senac, 2004, p.13.

${ }^{83}$ As grandes referências teóricas nesta época são Viena e Paris. ALBUQUERQUE, Alexandre. Apud SAMPAIO, Maria Ruth Amaral. Op. cit., p.140.

84 Victor da Silva Freire é português formado em Paris, na École de Ponts et Chauseés. Neste momento, é vice-diretor de Obras Municipais. 
praça e abrigar um monumento; a valorização e o aproveitamento do sítio natural de São Paulo formado por vales e esplanadas." 85

De iniciativa da Secretaria de Agricultura do Estado, o engenheiro Samuel das Neves apresenta outra proposta. As transformações urbanas não deixadas ao acaso inauguram as intervenções nos centros da cidade como objeto de discussão científica e de projeto. Numa visão geral, os "melhoramentos"86 previstos nos projetos eram basicamente ligados a áreas adjacentes ao Vale do Anhangabaú, como o alargamento da rua Libero Badaró e a demolição dos edifícios lindeiros ao vale; o ajardinamento do vale; e a demolição de alguns edifícios visando o aproveitamento da encosta entre a rua Libero Badaró e o Vale do Anhangabaú.

Joseph-Antoine Bouvard, urbanista francês que visitava a América, é chamado para apaziguar a discussão entre municipalidade e estado e propor uma solução plausivel e conciliatória. Propõe a construção de dois edifícios particulares na encosta do vale, com um espaço de $29 \mathrm{~m}$ entre eles e que seria usado como um belvedere público sobre o parque. ${ }^{87}$

Conforme indica Maria Cristina Leme, numa perspectiva ampla do urbanismo no Brasil, o período de 1930 a 1950 caracteriza-se pela visão mais abrangente dos projetos urbanos através da elaboração de planos. Conforma-se, neste momento, a organização jurídica e administrativa do modo de gestão urbana, o que inclui as intervenções urbanas como objeto de interesse. O Plano de Avenidas, elaborado por Francisco Prestes Maia, em 1930, é o exemplo significativo da nova forma de intervir na cidade neste período.

"Propondo um sistema articulado de vias radiais e perimetrais, este engenheiro, formado pela Politécnica de São Paulo, transforma a comunicação entre 0 centro da cidade e os bairros e dos bairros entre si e a cidade. Projeta a cidade que se expande de forma extensiva sobre pneus, substituindo a cidade de alta concentração de atividades e pessoas em que 0 transporte coletivo se faz através do metrô ou o bonde." $" 88$

A partir da década de 1930, o Anhangabaú sofre freqüentes intervenções, motivadas primordialmente por obras viárias, as quais acabam

\footnotetext{
${ }^{85}$ LEME, Maria Cristina da Silva. A formação do pensamento urbanístico, em São Paulo, no início do século XX. Espaço e Debates, n.34, pp.64-70, 1991.

${ }^{86}$ Segundo Maria Cristina Leme a palavra "melhoramento" designa, neste momento, qualquer tipo de intervenção urbana, desde saneamento até arborização de ruas e praças. Idem, ibidem.

87 Sobre os projetos e as suas particularidades ver SIMŐ̃ES, José Geraldo.Op.cit.

88 LEME, Maria Cristina da Silva. A formação do pensamento urbanístico no Brasil. 1895-1965. São Paulo: Nobel/FAU-USP/FUPAM, 1999.
} 


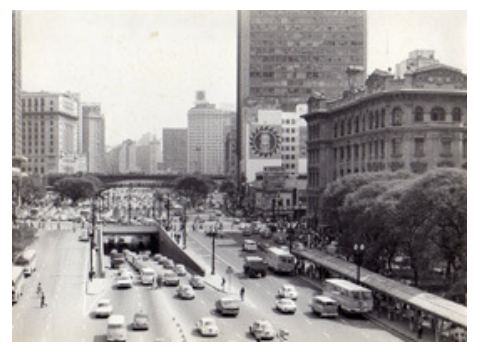

Fig.53 Estado do Vale do Anhangabaú na ocasião do concurso. configurando uma outra paisagem. Estas obras modificam a vocação paisagística do lugar a ponto de se questionar a designação de "parque" para esta área. Cria-se uma imensa calha viária de tráfego intenso e também de grandes problemas estruturais - como é o caso da canalização do riacho incapaz de dar vazão ao fluxo de água, principalmente durante as épocas de chuva. Menciona-se também a desorganização do tráfego e das rotas, provocando conversões perigosas no trânsito e a impossibilidade de transposição da cidade pelos pedestres. Os pedestres são aqueles que mais sofrem, pois esta ambientação é incapaz de possibilitar um percurso agradável devido à dificuldade de acesso aos meios de transporte e à própria poluição do ar.

Até a década de 1980, as obras realizadas no vale são isoladas e solucionam problemas pontuais; conforme as necessidades mais prioritárias vão surgindo intervenções que resultam numa fragmentação dos problemas e desarticulação dos acessos. Durante estas freqüentes iniciativas emergenciais, a maior importância foi dada às questões de cunho pragmático de circulação viária. Neste sentido, o Vale do Anhangabaú acaba perdendo gradativamente seu potencial paisagístico, histórico ou artístico e se configura como o principal pólo das redes de transporte metropolitano. Apenas alguns indícios de sua vocação paisagística sobrevivem, como é o caso do jardim ao lado do Teatro Municipal.

A área configura-se então como um enorme complexo viário, de cruzamentos, meios de transportes e fluxos de diversos tipos. Em São Paulo, da mesma forma que parques e leitos de rios são usados como calhas viárias, também muitas praças tornam-se equipamentos destinados ao transporte, como é o caso da Praça da Bandeira, que funciona como um terminal de ônibus. Neste sentido, uma série de estruturas pertencentes ao sistema de transportes marca a paisagem urbana do Vale do Anhangabaú, conformando um espaço complexo que abriga uma densidade ingente de fluxos de circulação, promovendo ligações em diferentes sentidos e escalas territoriais (locais, municipais e metropolitanas). O elevado Eusébio Stevaux e as passarelas usadas como acesso aos terminais rodoviários de ônibus interferem na fisionomia da região, espelhando sempre um conflituoso emaranhado de soluções para passagens e circulação. Na década de 1970, o potencial metropolitano da área acaba se confirmando com as construções do metrô. Configura-se então uma área de intenso fluxo intenso, 
tanto local como regional. É também neste momento que se verifica uma mudança na volumetria urbana, com a substituição dos edifícios de pequena altura por enormes condomínios verticais.

democracia e cidade: a proposta do concurso

A problemática da transposição do Vale é fato estabelecido precocemente e que perdura até a década de 1980, quando se percebem as mudanças da sua vocação: de elemento geográfico simbólico ou lugar de encontro e lazer para a condição de calha viária. 0 resultado formal herdado até esta data pode ser considerado um efeito da cisão existente durante anos entre os estudos sobre o espaço edificado e os processos sociais recursivos nos centros urbanos. A separação das especializações acaba fomentando uma visão especializada da paisagem, desconsiderando as várias questões que implicam na apreciação da paisagem como fenômeno de interdependência entre a estruturação do espaço e a morfologia social. Acontece o que Antônio Augusto Arantes pontua:

"Quando desdobrada pelo viés da dimensão cultural, observa-se que esta afirmação de exterioridade do espaço e da paisagem em relação às práticas sociais tem levado à compreensão do edificado como realidade residual, desprovida de carga simbólica específica, terreno pura e simplesmente determinado pela lógica de mercado (aliás, como se esta pudesse prescindir de componentes simbólicos). [...] convencidos quanto à autonomia desses dois planos (o social e o espacial), também os técnicos envolvidos com as políticas urbanas têm se sentido à vontade para desautorizar - nesse reino de especialistas e especialidades - os pontos de vista da população a respeito do futuro da cidade e legitimar a concepção de que bastariam, para se atingir um patamar adequado de qualidade de vida, os princípios técnicos e instrumentos de planejamento desenvolvidos por urbanistas, engenheiros e economistas." ${ }^{89}$

Obviamente que a urgência de uma reorganização do Vale neste período não tem como pressuposto primeiro a questão paisagística ou de preservação do seu estatuto de "parque", mas advém, principalmente, de uma questão de organização viária e de fluxos..$^{90}$

"Mais recentemente, em virtude do clima gerado pelo insuportável fluxo de veículos e descontrolado acúmulo de pessoas em torno do principal corredor paulistano, a realidade do Vale, tangenciando o inaceitável, obrigou a municipalidade a adotar soluções de travessias para pedestres que ao mesmo tempo em que proporcionavam segurança, desafogavam as vias do Anhangabaú, liberando ainda algumas áreas centrais para recriação de

${ }^{89}$ ARANTES, Antonio Augusto. A política como ação simbólica. In: Paisagens..., op.cit., p.86.

90 Justificativa técnica para as três novas passarelas. Arquitetura e construção. São Paulo, n.170, nov, pp.8-12, 1980. 


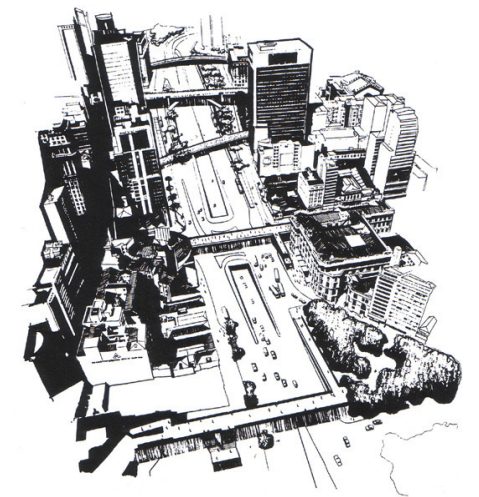

Fig.54 Proposta da Emurb. espaços verdes para os habitantes." 91

É através da chancela da travessia dos pedestres que a Emurb (Empresa Municipal de Urbanização) propõe a construção de seis passarelas sobre as vias do Vale. Assinale-se a aceitação da proposta de Reelaboração do Vale do Anhangabaú defendida pelo arquiteto Vilanova Artigas, em 1974, a qual tem como principal característica o trato do problema urbano de modo mais abrangente: a ligação viária que corta a cidade rio a rio, do Tietê ao Pinheiros.

"Ele propõe que o Vale deixe de funcionar como terminal de ônibus e passe a ser uma área de circulação apenas. 0 mais interessante, entretanto, é que 0 projeto não resolve apenas um problema de funcionalidade e eficiência, como é o caso das passarelas, mas acaba criando esplanadas que ligam o centro velho e o novo."92

A proposta da Emurb acaba acarretando numa série de discussões sobre a questão, as quais ficam patentes na quantidade de publicações sobre as soluções possíveis nos principais jornais de circulação da época.

A proposta é abertamente criticada por vários grupos profissionais, principalmente 0 dos arquitetos e urbanistas. As discussões se concentram basicamente nas soluções possíveis para a transposição da calha viária, seja por passarelas ou através de passagens subterrâneas. "Qual é a melhor solução para a travessia de pedestres e a circulação de carros no Vale do Anhangabaú?" A pergunta que abre a coluna $O$ Vale em discussão, da Folha de São Paulo, mostra a opinião de diversos profissionais, usuários, técnicos, etc. A partir do modo como o problema é colocado, principalmente a partir da circulação e solução para a ordenação dos fluxos, nota-se que o vale é considerado somente um limite a ser vencido, uma barreira a se transpor. Dessa forma, outras abordagens aparecem apontando outros problemas que não apenas os infraestruturais, especialmente aquelas desenvolvidas à luz da valorização do lugar como importante marco referencial da cidade. Este processo de discussão, que se inicia através de artigos publicados em jornais, acaba por desdobrar-se no Concurso Público: Vale do Anhangabaú, em 1981.

A proposição de um concurso público assinala também a abertura do processo decisório de intervenções sobre a cidade, marcado por um objetivo político. Mesmo com as dificuldades encontradas na efetivação do processo,

\footnotetext{
91 Idem, p.9.

${ }^{2}$ A opinião é de Marcelo Nitsche no artigo intitulado "Segurança deve vir antes da estética". Folha de São Paulo, São Paulo, jan, 1981
} 
abre-se a possibilidade da participação das várias camadas da população na decisão que abrange a reestruturação do espaço público - entendido em sentido amplo, não apenas físico, mas de participação coletiva nas decisões de interesse comum..$^{93}$ Nesta acepção, o concurso, além de contar com as propostas de profissionais, promove também discussões públicas e seminários técnicos abertos. Acontecem ainda trabalhos de estudo sobre o Vale do Anhangabaú que muito contribuem para as idéias que circulam naquele momento sobre intervenções em espaços públicos.

Em geral, os projetos apresentados no concurso enfocam alguns aspectos bastante semelhantes quanto aos objetivos almejados, principalmente assinalando a necessidade de ampliar o escopo da proposta para além do problema específico do fluxo viário. Desse modo, além da proposição de resolver os problemas relativos à acessibilidade física, as propostas buscam ainda soluções que permitam a sociabilidade entre os cidadãos. Portanto, trata-se também de promover a reconfiguração do lugar observando seu caráter simbólico de representação, identidade e pertencimento. Este pressuposto passa a existir até mesmo nas prerrogativas colocadas sobre o fator econômico: "Tirado em consenso: O valor humano, o espaço social vivenciável, e não de simples circulação, é o fator preponderante às condições de custo monetário de execução." ${ }^{4}$ É dessa forma que a problemática da complexa estrutura de redes viárias (automóveis, trolebus, metrôs) e de infra-estrutura (os problemas de escoamento e vazão do córrego soterrado) é ampliada para questões relativas à vocação do lugar, ao uso espontâneo da população, à preservação dos monumentos e da paisagem como referências e identidade, enfim, toda retórica que envolve o esforço de "humanizar" o projeto funcional e criar efetivamente um "espaço público" de debate político.

As questões advindas da problemática urbana inserem-se de forma ampliada abarcando outros elementos que fazem parte da complexidade da cidade. Esta abrangência pode ser considerada um momento de aproximação com as discussões do VIII CIAM através da chancela da preexistência. Estas

93 Sobre o tema destaca-se: Anhangabaú: o concurso para organização do espaço urbano. $A$ Construção em São Paulo (1725): 1981, p. 18; Anhangabaú: reorganização do espaço é colocada em debate. A Construção em São Paulo (1731): 1981; p. 22; A comunidade quer e pode se manifestar, afirma Bergstron. Revista Projeto (29): mai, 1981, p.44.

${ }^{94}$ A comunidade quer e pode se manifestar, afirma Bergstron. Revista Projeto. São Paulo, n.29 maio de 1981, p.45. 
preocupações entram em pauta exatamente quando há fatores que apontam as oscilações entre permanência e inovação, o que retoma novamente o foco para a dialética existente entre 0 antigo e 0 novo, para a "vocação do lugar" e consequentemente para a dimensão cultural existente no lugar. Apesar da possibilidade de diálogo entre a disciplina urbana e as questões intrínsecas à Teoria da Restauração, apontada no decorrer do trabalho, e que poderia colocar o problema de forma mais ampla, a discussão é retomada muito mais pelos argumentos apontados no segundo pós-guerra. Dessa forma, a relação entre 0 antigo e o novo aparece na análise deste concurso, através das questões relativas à preexistência pelo viés das observações presentes no VIII CIAM, não apenas pelos elementos morfológicos, mas também, pelos elementos espontâneos existentes no lugar.

\section{o coração da cidade}

É evidente a apropriação por parte dos arquitetos e urbanistas brasileiros das idéias motivadas pela crítica ao urbanismo funcionalista da geração do segundo pós-guerra europeu. Portanto, pode-se considerar que aquele ideário relativo às concepções dos projetos de cunho urbano pretendido por Lina e delineado num primeiro momento no caso do Centro Histórico de Salvador sobre as questões relativas ao pertencimento, identidade e vocação do lugar encontram-se em pauta. Ao que parece, a maior parte dos participantes do concurso inicia o projeto através desta mesma problemática, o que é conseqüência do próprio contexto de abertura política da época, no entanto, percebe-se uma diferença no modo de apropriação da problemática durante a importação dos paradigmas estabelecidos vinte anos antes na Europa.

Dessa forma, o modo de análise e leitura do contexto urbano é um dos temas trabalhados pelos arquitetos deste período a fim de esclarecer também as formas de uso e significado simbólico do lugar, além dos aspectos físicos e funcionais. Para tanto, os procedimentos utilizados diferenciam-se entre si, mas envolvem, sobretudo, a qualificação do entendimento físico do ambiente e a interação com a percepção de quem vive neste lugar. Nesta visão, as noções de "lugar", "vocação" e "habitar" também perpassam pelas discussões. A manipulação destas noções constrói uma nova visão de intervenção, a qual parte da premissa da construção do novo a partir da continuidade com elementos 
existentes no lugar. Há uma determinação por parte dos arquitetos e urbanistas envolvidos no concurso em revisar o método de atuação, principalmente nestes espaços públicos considerados representativos enquanto sociabilidade e identidade.

Algumas opiniões profissionais no debate do concurso devem ser colocadas em evidência:

"a solução para o Vale do Anhangabaú deve considerar o sentido de vivência coletiva do espaço urbano em questão, 'não se permitindo que interesses econômicos interfiram no projeto', pois 'não podemos entender a solução do Vale desvinculada da cidade em sua totalidade"

Helena Ayoub Silva, relatora do grupo 1 (Programa para o Vale do Anhangabaú) $)^{95}$

"todas as reurbanizações são irreversiveis, mas espero que se escolha um projeto que devolva ao Vale a condição de parque, de área verde e de lazer."

Ernani da Silva Bruno, historiador. 96

"O projeto deverá ser aberto, no sentido de permitir a livre apropriação do espaço urbano pelo usuário, levando em consideração não só suas necessidades, seus anseios e alegrias. O Vale não deve ser destinado unicamente à circulação das forças de trabalho, mas como ponto de referência, convivência e 'estar' na cidade."

Grupo 2 de discussão (fator Econômico) $)^{97}$

'Devo, finalmente, dizer algo sobre a diferença entre 'espaço' e 'lugar', em livro ora em preparo, defino lugar como aquele espaço que revestimos de afetividade, que tem uma particular significância em nossa vida. Nem todo espaço se transforma em lugar, sendo que cada indivíduo reúne um conjunto determinado de lugares seus; por outro lado, há espaços que adquirem o significado de lugar para muitas pessoas, quiçá para multidões, aumentando consideravelmente a sua importância urbana".

Jorge Wilheim, vencedor do concurso. ${ }^{98}$

"Estas considerações são particularmente significativas quando o objeto em questão não é uma área qualquer indefinida e amorfa da cidade, mas é o seu 'cuore', talvez a mais importante área da metrópole pelo que ela tem de qualidade arquitetônica e paisagística, enquanto lugar de tradição cívica, de lugar de encontro, de permanência, de passagem, de trabalho e de lazer, onde ocorre uma riquíssima gama de atividades."

Paulo Bastos, Siegbert Zanettini, José Sales Costa, terceiros colocados no concurso. .99

Estas opiniões acabam conformando um quadro de discussão onde é possivel identificar a constante preocupação, ao menos enquanto opinião e princípios, com o tema do "coração da cidade" e a decorrente motivação de

${ }^{95}$ Anhangabaú: reorganização..., op.cit, p.22.

${ }^{96}$ Idem, p.23.

${ }^{97}$ A comunidade..., op. cit., p. 45 .

98 WILHEIM, Jorge. De espaço a lugar. Arquitetura e Urbanismo, n.42, jun-jul, 1992, p.41.

99 Anhangabaú: uma conquista dos arquitetos e da população. (Suplemento Especial) Revista Projeto, n.31, jul, 1981, p.49. 
buscar no espaço público a solução para a socialização e participação do homem na vida urbana. Nota-se então a importação da crítica aos planos reguladores e à forma de se conceber os projetos que muitas vezes ignoram 0 modo de uso espontâneo preexistente e cotidiano da cidade. Paralelamente às tarefas cotidianas do homem encontra-se um lado involuntário e afetivo que a forma não é capaz de condicionar, mas que pode, no entanto, possibilitar sua manifestação. “¿Cómo, pues, al reconstruir una ciudad ya existente o al crear una nueva, puede tenerse la seguridad de que la higiênica y bien condicionada vaina estará llena de vida?"100 Esta pergunta parece ressoar sobre as discussões do concurso. Algumas idéias de sistematização do projeto relacionadas ao uso cotidiano e à espontaneidade como elementos necessários para retomar o valor simbólico do centro da cidade são desenvolvidas aqui.

Durante o VIII CIAM nota-se que as diferenças culturais e sociais de cada participante e também as experiências específicas de cada um conduzem a caminhos bastante diversos no enfrentamento do tema. É possível identificar estas divergências desde 0 início, quando se fala da própria idéia de espontaneidade. Este tema da espontaneidade, que parte da observação do uso existente e da própria apropriação dos lugares pelos cidadãos, é relevante uma vez que parece ser a alternativa usada pelos arquitetos e urbanistas durante a criação e proposição da nova forma física do coração da cidade. Esta relação de identificação e pertencimento estabelecida entre homens e construções é um fator entendido como possibilidade de se dar a continuidade orgânica àquilo que já existe. A criação do edifício ou do espaço novo é uma espécie de atualização da vida nova e renovada, ou seja, já é uma resposta às exigências dadas pelo presente; é uma "possibilidade". Esta "possibilidade" faz parte de um cenário que se renova constantemente e, portanto, insere-se dentro de um processo histórico da síntese entre o que permanece e o que se renova, entre o antigo e o novo.

"L'equilibrio estetico, l'armonia, è una sintesi dinâmica tra una possibilita nuova e il condizionamento della tradizione di cui il valor è riconosciuto próprio in quanto la nuova funzionalità non si pone come astratta ma come effettivo rinnovamento in una continuità. É chiaro che l'insistenza sull'elemento permanente e sulle necessarie premesse storiche non tende a paralizzare l'emergenza dell'avenire [...]"101 (grifo nosso)

100 McCALLUM, lan. Elementos espontáneos en la ciudad. In: ROGERS, E. N., SERT,J.L., TYRWHITT. J. El Corazón..., op.cit, p.64.

$101 \mathrm{PACl}$, Enzo. Op.cit, p.ix. 
Alguns arquitetos e urbanistas conservam a idéia de que espontaneidade parte do modo como, cotidianamente, o cidadão se apropria dos espaços, no sentido de dar outros usos que não aqueles imaginados durante 0 processo projetual do arquiteto. Outros acreditam que a espontaneidade pode ser um dado colocado a priori, pois diz respeito a situações já encontradas num determinado lugar, como as relações sociais, culturais ou políticas já existentes. Nesta visão, de certa forma, pré-existe algo que o arquiteto deve apreender (não apenas aspectos morfológicos, mas também, do próprio programa a ser delineado) e levar em conta durante o projeto. Como resposta metodológica para o enfrentamento da questão da espontaneidade no projeto, encontram-se variadas posições que mais adiante necessitam ser detalhadas para que logo sejam comparadas com a maneira de Lina lidar com o tema.

Alguns recorrem à história para retomar as origens do significado da cidade e sua espontaneidade. Sert evoca as origens das palavras urbs e polis, no sentido de lugar destinado à função pública e de reunião dos cidadãos. Giedion complementa essa idéia retomando as estruturas físicas desse modo de organização participativa: a ágora e o forum romano.

Gregor Paulsson trata estes precedentes históricos apontados por Sert através de uma visão cuidadosa. Faz uma anotação importante: Forum Romano, Ágora de Atenas e a Praça São Marcos são espaços perseguidos como exemplos de sociabilidade e espontaneidade pelos arquitetos deste período, mas, no entanto, são resultantes de um espírito de uma época, um tipo de organização social, política e cultural particular de um tempo. Tomá-los como exemplo deve ser uma ação consciente, uma vez que existe o risco de se criar simulacros, ou seja, emprestar soluções formais esquemáticas que são indiferentes ao contexto e às necessidades reais do lugar de intervenção.

O centro de vida comunitária, para Le Corbusier, é análogo a um teatro. Um teatro espontâneo. Estes lugares têm a característica de impressionar qualquer sujeito através do que ele próprio chama de "pontos matemáticos de perfeita harmonia". Desse modo Le Corbusier insere também a exigência estética como uma necessidade humana. Esta harmonia somente é conseguida caso haja uma perfeita proporção, onde o espectador se identifique e se unifique com o que o rodeia. Se não há harmonia o expectador é incapaz de incorporar a cena ou mesmo de se sensibilizar. E esta é a responsabilidade do arquiteto. A 
missão de um teatro espontâneo é despertar a intensidade da vida, os grandes momentos da vida verdadeiramente participativos e não meramente assistidos. Deve possibilitar a explosão da criatividade sem avisos prévios. Portanto, a missão do arquiteto é apenas oferecer este cenário bem dimensionado para que a necessidade latente do homem de se reunir congregue-se de forma afirmativa para a satisfação do espírito. A medida humana é, pra Le Corbusier, o elemento através do qual podem ser encontradas as mais agradáveis soluções para este espaço criado. A arquitetura depende desta relação entre coisas e medida humana para que seja de fato agradável para o espírito humano. Consequentemente, a própria espontaneidade depende da capacidade do arquiteto em dimensionar as coisas. Esta sabedoria sobre as dimensões arquitetônicas em relação com a sensação agradável proporcionada no homem deve fazer parte também dos projetos modernos como expressão vital para seu próprio êxito. 0 esquecimento deste fator implica necessariamente na perda da humanidade das coisas. Esta necessidade da medida humana exerce, para Le Corbusier, uma influência sobre a ação regeneradora da atmosfera "sufocantemente mecânica" 102. Percebem-se aqui algumas diferenças sobre 0 foco da espontaneidade.

Apesar dos arquitetos estarem de acordo com a importância da espontaneidade, os processos diferenciam-se de acordo com cada interpretação. Para Le Corbusier, o trabalho do arquiteto é apenas possibilitar o espaço para que a espontaneidade ocorra, ou seja, basta a capacidade do arquiteto de saber relacionar as dimensões. ${ }^{103} \mathrm{~A}$ tarefa do arquiteto é encontrar a harmonia do espaço projetado durante o desenho do projeto. Trata-se de um procedimento de composição, de equilíbrio de formas, exercício isolado que parte basicamente do repertório de criação do arquiteto. Outros acreditam que a espontaneidade pode ser algo intrínseco, interno ao processo, e não apenas um resultado da apropriação daquele espaço. A espontaneidade neste caso é dada, pré-existe num determinado lugar. Arquitetos e urbanistas devem aprender sobre a espontaneidade e considerá-la a posteriori. A espontaneidade quer dizer a forma cotidiana como o cidadão utiliza, simboliza ou dá valores à cidade. Incorporar a

\footnotetext{
102 CORBUSIER, Le. 0 coração como ponto de reunião das artes. Idem, pp.41-52.

103 Essa preocupação aparece em Le Corbusier a todo momento e o sistema de medidas criado por ele, o modulor, é o exemplo concreto desta preocupação.
} 
espontaneidade no processo é qualificar o novo de sua particularidade, é dar continuidade à sua vocação implícita e, portanto, aproximar presente e passado, antigo e novo. Considerar a espontaneidade significa entender a cidade em sua complexidade, em suas condições formais e físicas preexistentes somadas às experiências vividas naquele imediato. Esta medida da espontaneidade é apreciável no projeto de Lina para o Centro Histórico, visível principalmente na proposta da Cachoeira do Pai Xangô, por exemplo, em que a arquiteta capta um acontecimento espontâneo de um uso efêmero e dado por aqueles que habitam o lugar e o potencializa como possível realidade concretizada. 0 programa não consiste numa listagem de determinadas necessidades funcionais, mas é um dado da realidade. Portanto, a espontaneidade é o que constrói o programa. Este procedimento visível na proposta da Cachoeira do Pai Xangô antecipa algumas propostas da arquiteta Lina para o projeto no Anhangabaú.

Sert também discorre sobre as características do coração, sua forma, seu dimensionamento, sua função social de recuperar o espírito cívico, os elementos compositivos e principalmente a necessidade de separação de pedestres e automóveis. A estrutura do seu pensamento vem encontrar-se com a estrutura proposta por Sitte, pois retoma as questões morfológicas específicas encontradas em diferentes espaços. Este lugar é onde reina o pedestre, pois esta é a única maneira de permitir o encontro entre as pessoas, quaisquer que sejam. Esta reflexão é enriquecida, na visão do autor, por elementos novos da vida atual que constroem positivamente a variação do coração - resultado do avanço do conhecimento técnico e das facilidades de comunicação.

"La radio, el cine, la televisión y la información impresa están absorbiendo hoy todo el campo de comunicación entre los hombres. Cuando estos elementos están controlados por unos pocos, la influencia de estos pocos sobre los muchos puede convertirse en una amenaza para nuestra libertad. Las condiciones actuales de nuestras ciudades tienden a agravar esta situación, porque la ampliación excesiva, la congestión del trafico y la dispersión han separado al hombre del hombre, estableciendo barreras artificiales."104

Conforme esboçado, as questões decorrentes deste CIAM promovem uma série de ramificações no modo de sistematização, ou seja, no ato de projetar e desenhar as propostas. Assim como a divulgação das idéias acontece de forma bastante diferenciada e muitas vezes até antagônicas, o resultado

104 SERT, J. L. Centros para a vida da comunidade. Idem, p.6. 
formal dos projetos não escapa à diversidade de interpretações. Isto também é claramente verificável no Concurso: Vale do Anhangabaú e nas diferentes soluções para as mesmas abordagens.

O que aparece como diferença é o modo como estas idéias são colocadas em prática, tal como se verifica na apresentação dos projetos e desenhos das propostas.

Cabe aqui destacar a qualidade do material de levantamento elaborado pelos participantes do concurso através de registros fotográficos que procuram mostrar o cotidiano da cidade em seus diversos substratos, usos, particularidades e heterogeneidade. Remetem-se frequentemente aos usos cotidianos e à apropriação espontânea dos espaços. No entanto, este material demonstrativo de toda a análise para a elaboração do projeto parece ser deixado de lado a partir do momento em que se inicia o desenho. A impressão é que há um distanciamento entre esta análise e 0 projeto arquitetônico durante 0 processo, o que é possível perceber quando se observa alguns desenhos. Ou seja, existe uma autonomia fechada e independente entre as etapas de análise, de concepção e de desenho, pois os projetos parecem ignorar toda a retórica, fechando-se em desenhos que conformam eixos, áreas e composições formais ligados ao repertório de relações entre volumes e planos, o que é totalmente ilegivel para aqueles que usufruem do lugar. Cabe aqui a indagação de como toda a reflexão sobre o coração da cidade e seus pressupostos pode de fato comparecer na elaboração dos projetos. Ao determinar toda a gama de usos, por exemplo, as propostas, em geral, passam diretamente para o estágio de criação individual que organiza as funções do lugar: aqui é parque; aqui é praça de estar;

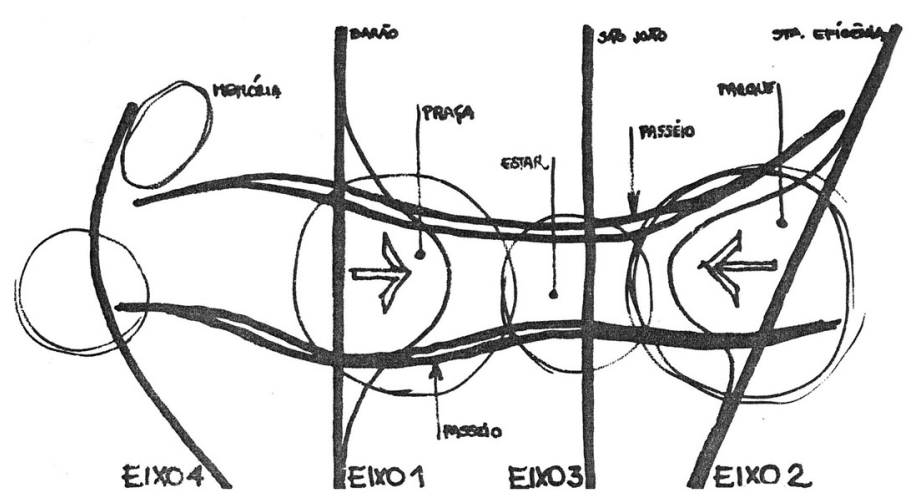

Fig.55 Desenho da equipe do arquiteto Paulo Bastos. aqui é praça cívica; aqui é memória. As propostas têm, desta forma, uma incongruência em seu processo porque a continuidade entre 0 antigo e o novo não se efetiva realmente. Apesar da ampliação das preocupações do arquiteto sobre o projeto de intervenção na cidade, a proposta evidencia apenas os aspectos da viabilidade dos fluxos e os detalhes técnicos da infra-estrutura. Esta leitura somente é possível na medida em que se acredita que a questão do uso é um aspecto final do projeto, determinado pela "forma 
bem condicionada". ${ }^{105}$ Ou seja, o uso espontâneo não faz parte do processo a não ser como possibilidade futura. Cabe questionar então se o levantamento tão bem formulado e a retórica importada tornam-se apenas ilustrações e textos.

\section{metodologia e processo: lina e o vale do anhangabaú}

A partir dos aspectos assinalados anteriormente, acredita-se que 0 trabalho de Lina diferencia-se daqueles apresentados pelos demais participantes do concurso pela coerência ao tema da preexistência mostrada durante todo 0 processo, desde a análise do local e dos ideais propostos para sua transformação até a solução urbanística-arquitetônica proposta pela arquiteta e sua equipe. 0 estudo sobre 0 uso espontâneo do local pelos seus usuários participa da elaboração do programa, constituindo elemento fundamental do projeto. Retoma-se aqui a questão colocada no decorrer da dissertação sobre 0 "uso espontâneo" como elemento constitutivo do projeto nas intervenções propostas por Lina. A arquiteta transfere o foco das questões para a observação da realidade preexistente e torna esta preexistência elemento intrínseco ao seu método. Pressupõe a inserção dos princípios evocados em seus procedimentos, como a questão relativa à espontaneidade, continuidade e vocação do lugar na concepção de um espaço verdadeiramente público e na ação sobre um lugar representativo da memória.

Cabe destacar que sua proposta não chega a ser escolhida pelos jurados do concurso e é praticamente tomada como "brincadeira" por alguns críticos. Esta crítica advém basicamente da leitura formal do projeto, que num primeiro momento causa bastante estranhamento106- o que é uma constante em boa parte dos seus projetos. No entanto, não se pode entender o projeto de Lina sem identificar o seu procedimento projetual e sem considerar sua trajetória. Também é relevante considerar a proposta da arquiteta como parte de um "concurso de idéias", e não como proposta fechada e acabada. Neste sentido, Lina coloca-se numa postura provocativa no sentido de questionar a motivação

105 Este procedimento aparece exatamente como a forma com que Le Corbusier entende a produção dos lugares (teatros) para possibilitar a espontaneidade, conforme observações desenvolvidas anteriormente.

106 Muitos acham a proposta parecida com o Minhocão, considerado uma solução paliativa e destruidora da paisagem urbana. O "estranhamento" pode ser identificado em outros projetos como, por exemplo, nos croquis para a solução estrutural do MASP, onde Lina parte da forma de uma pirâmide e chega na solução do vão sustentado pelos gigantescos pilares, ou, nas torres de concreto do SESC-Pompéia. 
original do concurso com ênfase, sobretudo, na organização infra-estrutural do vale. Certamente há a exigência de revisão das questões funcionais dada pelas condições do vale naquele momento, entretanto seu trabalho de criação do novo busca abarcar a cidade em sua complexidade, observando e tentando dar possibilidade à convivência das várias estratificações temporais no tecido urbano, a vocação paisagística do lugar, o seu uso cotidiano, os conflitos sociais ali presentes, além do seu significado simbólico. Em nenhum momento percebese a tentativa de uniformizar ou diluir as contradições encontradas. 0 antigo e 0 novo convivem apesar das suas diferenças e contradições.

A idéia proposta por Lina para o Vale do Anhangabaú é a de transformá-lo num parque. Para a arquiteta e sua equipe, São Paulo é uma cidade carente de áreas livres e verdes, considerando o tecido densamente construído da malha urbana. O Vale do Anhangabaú coloca-se como uma das únicas possibilidades de solucionar esta carência, propiciando uma melhor qualidade de vida à população, além de funcionar como ponto de referência e de identidade para os habitantes da cidade. Ao mesmo tempo, acredita-se que 0 Vale do Anhangabaú tem uma "vocação" distinta daquela que se encontrava naquele momento. A proposição do coração da cidade no Vale do Anhangabaú, como lugar de encontro e sociabilidade, levantada pelos arquitetos e urbanistas do período, é, na verdade, a retomada de uma função que se perdeu durante os anos com as sucessivas transformações viárias ocorridas. Portanto a renovação do lugar é proposta por Lina através de uma referência do passado do próprio Vale do Anhangabaú, quando este ainda era um lugar de passeio e encontro, repleto de áreas verdes e caminhos sinuosos. "Voltará o grande café da esplanada do Teatro Municipal, centro de reunião ao ar livre, nas tardes ensolaradas e nas noites de concertos." ${ }^{107}$ Esta retomada de uma vocação pretérita não é uma ação romantizada, no sentido de reconstituir algo passado, mas, na verdade, é perseguida por Lina através da observação do presente, ou seja, da compreensão da realidade encontrada naquele momento.

As referências tomadas para a concepção do projeto são alguns parques urbanos, vistos no seu funcionamento livre e espontâneo.

107 BARDI, Lina Bo.Texto manifesto apud FERRAZ, Marcelo. Dois concursos: dois manifestos. Revista Caramelo. São Paulo, n.4, 1992. 
"O vale verde do Anhangabaú pode voltar, devolvido aos homens, libertado dos "perigosos inimigos": os carros, os pedestres, os transportes em cima.

A estrutura seguirá o Vale como um antigo aqueduto, embaixo, o rio dos pedestres, as árvores, o verde [...] Praça das Bandeiras é verde: já é "parque". 108

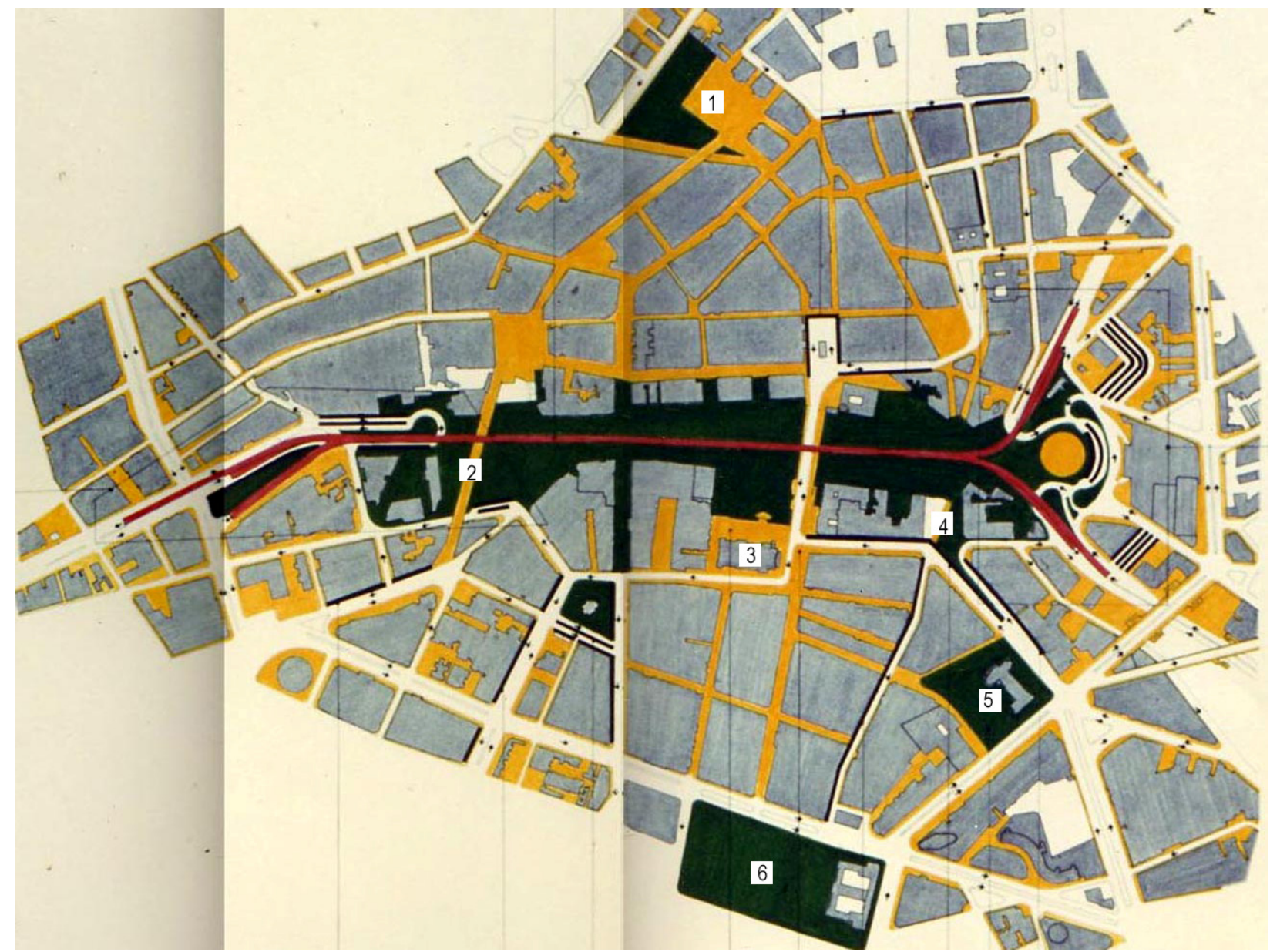

Fig.56 A proposta de Lina é transformar o Vale do

Anhangabaú num parque. Está destacado em amarelo as áreas destinadas aos pedestres; em verde escuro, as principais áreas verdes; em vermelho, a estrutura para veículos proposta sobre 0 vale. Inseriu-se alguns pontos de referência: 1.Pátio do Colégio; 2. Viaduto Santa Efigênia; 3. Teatro Municipal; 4.Largo da Memória; 5. Biblioteca;6.Praça da República.
A relação entre 0 antigo e o novo neste projeto é colocada através da simples consideração da continuidade do aspecto geográfico do vale, aspecto natural ignorado durante todas as modificações urbanas, mas que ainda, é uma especificidade da cidade de São Paulo, de sua história, de sua paisagem. Ou seja, o uso do próprio solo é a resposta da acessibilidade, tanto para a transposição do vale como para a solução dada à organização dos fluxos de transportes. Neste sentido, Lina não cria subterfúgios complicados para fazer a transposição do vale, como túneis ou rampas, mas, apropria-se da cota zero, da superfície existente, além de utilizar-se dos próprios elementos dados no tecido

\footnotetext{
108 Idem, ibidem.
} 
urbano, como é o caso do Largo da Memória.

Este largo construído na Ladeira da Memória era porta de entrada do núcleo urbano para quem chegava do interior de São Paulo, ou, era usado com objetivo de fazer a ligação entre "centro velho" e o "centro novo" da cidade. Com a modificação do vale e a complexa rede de fluxo de transportes, tanto rodoviário como metroviário, instalada nos seus arredores, este elemento urbano vai paulatinamente perdendo sua função tornando-se, cada vez mais, um lugar
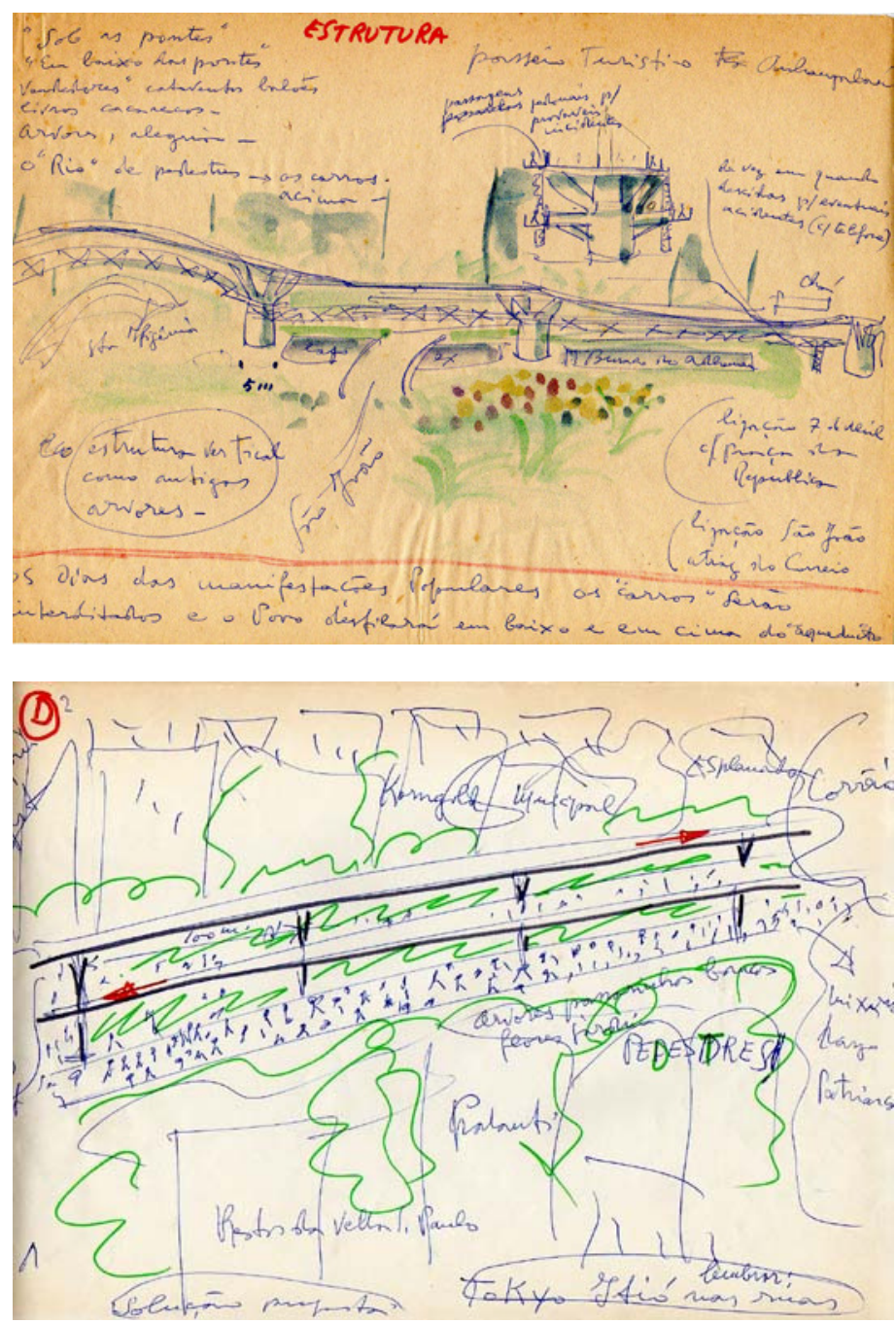

inóspito e depreciado. Esta realidade é passível de verificação através das sucessivas ações de vandalismo e os esforços de recuperação ou proteção. ${ }^{109} \mathrm{O}$ que Lina propõe é retomar sua função de ligação, através da inserção do próprio largo como elemento de transposição do vale. 0 Largo da Memória, existente no tecido urbano, é de fato inserido no projeto segundo sua antiga função de "acesso" e não como um mero monumento a ser contemplado e preservado. Portanto não se cria outros elementos que poderiam, de alguma forma, competir e tomar a função do largo existente. Novamente, pode-se considerar esta iniciativa da arquiteta uma maneira de "atualização" do monumento através do resgate da sua função e do seu uso como um forma de perpetuação do seu valor patrimonial, simbólico e afetivo, sem utilizar-se de meios formais ou oficiais que pressionem e fiscalizem a sua salvaguarda.

O mesmo processo de "atualização" do

Fig. 57 Croqui de Lina. Área do parque onde cruza com a Rua São João ("ex buraco do ademar")

Fig.58 Croqui de Lina mostrando o uso indiscriminado do parque. vale acontece também quando Lina propõe a acessibilidade aos transportes de massa por meio da descentralização dos pontos de ônibus em todo o entorno do parque. A pulverização dos pontos de ônibus nos arredores do Vale do

109 O Largo da Memória foi protegido no início da década de 1970 pelo município (Z8-200-083), tombado pelo Estado em 1975 e pelo Conselho Municipal de Preservação do Patrimônio Histórico, Cultural e Ambiental da Cidade de São Paulo (COMPRESP) em 1991. 


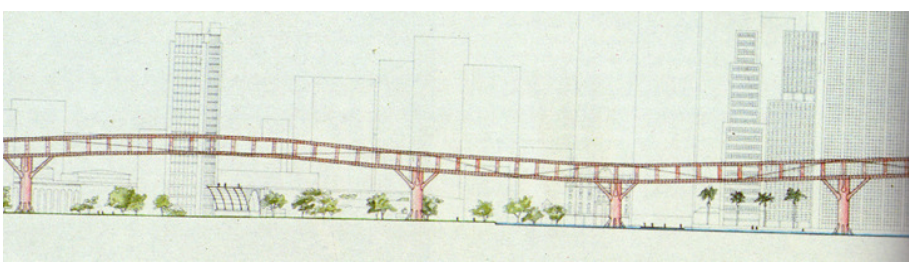

Anhangabaú é condizente com a proposta de uso dos espaços na cota da rua, do fluxo de pessoas pelos passeios existentes e pelo próprio parque. Desta forma, Lina também resolve 0

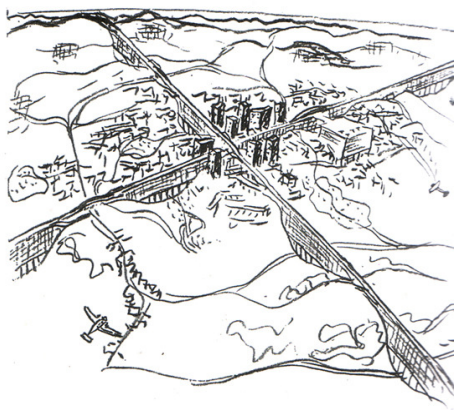

Fig.59 Vista da estrutura elevada sobre o parque.

Fig.60 Proposta de uma estrutura elevada para São Paulo de autoria de Le Corbusier. problema, conhecidos ainda hoje, causado pelos acessos aos terminais de ônibus. Verifica-se que toda a superfície da cidade é destinada àqueles que caminham na cidade. 0 simples ato de descer e subir 0 vale provoca a percepção do elemento topográfico, o qual sempre constituiu a paisagem urbana de São Paulo e sempre foi encarado como barreira tanto como acesso ao outro lado do vale como para o crescimento urbano.

A ligação norte-sul de veículos é elevada sobre o parque por uma estrutura de aço, como um enorme elemento escultórico e lúdico. Esta estrutura elevada proposta é a causa do estranhamento por parte daqueles que visualizam rapidamente o projeto. Este elemento, que chama a atenção de antemão no projeto, é incisivo e contrastante com a proposta de retomar o nível geográfico do parque. Muitas críticas ao projeto são embasadas na impressão desta estrutura. No final do texto sobre o projeto publicado por Marcelo Ferraz na Revista Caramelo, o autor afirma que realmente a proposta de vias elevadas sobre o vale não era uma simples 'brincadeira'. Para ele e para a equipe não é possível comparar o Elevado Costa e Silva com a solução da pista em altura aventada para o Vale do Anhangabaú; são soluções totalmente distintas. A idéia do elevado utilizado no Vale do Anhangabaú funciona como uma "fita"110 que se desloca sobre o parque. Além disso, a altura entre a superfície e a "fita" tem variações e é bem distinta da relação estabelecida no "Minhocão". Assim, não se dá a impressão de "laje" de cobertura, mas sim, de algo solto num plano verde. A proposta de elevar a circulação é a garantia do uso daquele espaço pelo povo, da eliminação das barreiras para aqueles que caminham. 0 que provoca estranhamento é a forma sinuosa da estrutura, que ao fugir da acidentada topografia do local através da elevação em altura ao mesmo tempo reproduz a mesma irregularidade encontrada no terreno, fazendo ecoar os acidentes topográficos agora no alto.

Esta postura de liberação da estrutura dos acidentes topográficos

110 "Fita" é o termo comumente usado pela equipe que participou do Concurso. Refere-se à característica estreita e solta da estrutura. 
existentes é uma solução já conhecida para a capital paulista. De fato, Le Corbusier já tinha proposto anteriormente um volume suspenso por pilotis, pairando sobre a acidentada topografia de São Paulo. Lina também suspende a via de circulação, mas ao mesmo tempo, cria um acidente geográfico artificial, similar à topografia encontrada no vale. Este procedimento parece reproduzir a proposta dada à Ladeira da Misericórdia, onde o novo incorpora a estrutura do existente. A "fita" criada reconstitui a sensação topográfica da área, resgatando a natureza orgânica do lugar.

A estrutura desta "fita" ondulada de circulação tem origem na observação de gameleiras, árvores robustas que com braços inferiores (raízes) e superiores (copas) podem sustentar todo o esforço produzido. Essas formas advindas da natureza produzem um efeito lúdico (como todo procedimento) que supostamente é objetivo do projeto para aquele lugar. A eficiência e rapidez esperadas pela elevação da circulação numa "fita" suspensa retilínea não é a proposta feita por Lina. Intencionalmente, a ondulação reduz a velocidade dos carros e transforma o que seria uma rápida passagem em possibilidade de passeio sobre o parque.

Como proposição de um concurso de idéias, Lina parece manifestar algo a se refletir: a transposição em massa entre rios deve ser feita exatamente neste lugar? Lina não acredita nisso - este uso é considerado incompatível com a vocação paisagística e simbólica ${ }^{111}$ do lugar e é bloqueado através da restrição à velocidade, ou melhor, da condição lúdica de passeio que lhe é dada: "aqueduto", "Tobogã"112. A proposta do tobogã como objeto lúdico e de contemplação dos visitantes do parque, apesar de parecer estranha num primeiro momento, constrói analogias com os costumes dos paulistanos da época, muito afeitos à experiência de observar o "espetáculo" proporcionado pela saída e chegada de aviões no Aeroporto de Congonhas. Nesta época, as famílias tinham costume de ir ao Aeroporto como lazer e diversão. Este costume paulistano também, aos olhos de um estrangeiro, parece algo bastante estranho.

"Numa cidade que só oferece a seus habitantes que nunca tiveram "carro" ou "sítio", como diversão aos domingos, o espetáculo da saída-chegada dos aviões de Congonhas, ou os campos do Ibirapuera, o Anhangabaú devolvido ao povo será o Parque Central da cidade, parque urbano, com sua estrutura

111 O que parece ser uma interpretação da Carta de Veneza sobre a restrição e limites de uso que o bem material merece.

112 Codinomes dado ao projeto. 
protendida e árvores de aço. Tour Eifel para cidadãos e turistas, montanha russa para ônibus cheios de crianças."113

Para a arquiteta, o estranhamento é um fator de curiosidade assim como a Torre Eiffel também o foi no momento de sua concepção. Apesar do investimento para a execução dessa estrutura ser bastante alto, a proposta sustenta-se como possibilidade de pensar a metrópole, de transformá-la realmente "dentro dos princípios do verdadeiro urbanismo, e com a maior possibilidade poética". 114

Não se pode entender devidamente esta proposta sem considerar todas as questões colocadas por Lina ao longo de sua trajetória profissional. Suas decisões são tomadas com base na observação de quem usa a cidade e dos espaços que tem possibilidade de fomentar as relações sociais e na necessidade e entendimento do uso cotidiano daquele espaço. O valor simbólico é resgatado e atualizado na consideração dos edifícios históricos não como "relíquias", mas na percepção humana do lugar, na referência da preexistência durante a criação do novo, e na negação da síntese e uniformidade das contradições encontradas no cotidiano da cidade. $O$ projeto não deve ser encarado no seu fim, apenas pelo seu efeito proposital de surpresa na imaginação de sua materialidade, sua análise deve adentrar-se ao próprio mecanismo de invenção, ao processo idealizado e às relações estabelecidas.

"É um projeto caro. Mas os sonhos são sempre a verdadeira realidade: Central Park, Buon Retiro, Hyde Park, Villa Borghese, Tour Eiffel...E sobretudo: " o povo não suja e estraga tudo, não joga sujeira de todos os lados". O povo respeita o que lhe pertence."115

A problemática colocada de início, ou seja, a solução do problema de circulação através de passarelas ou passagens subterrâneas, perde lugar de questão principal a ser trabalhada no projeto e Lina recoloca o problema em outros termos: para quem é este projeto e qual é a sua vocação?

\footnotetext{
113 Publicado em 1992. FERRAZ, Marcelo. Dois..., op.cit. 114 Ibidem.

115 lbidem.
} 


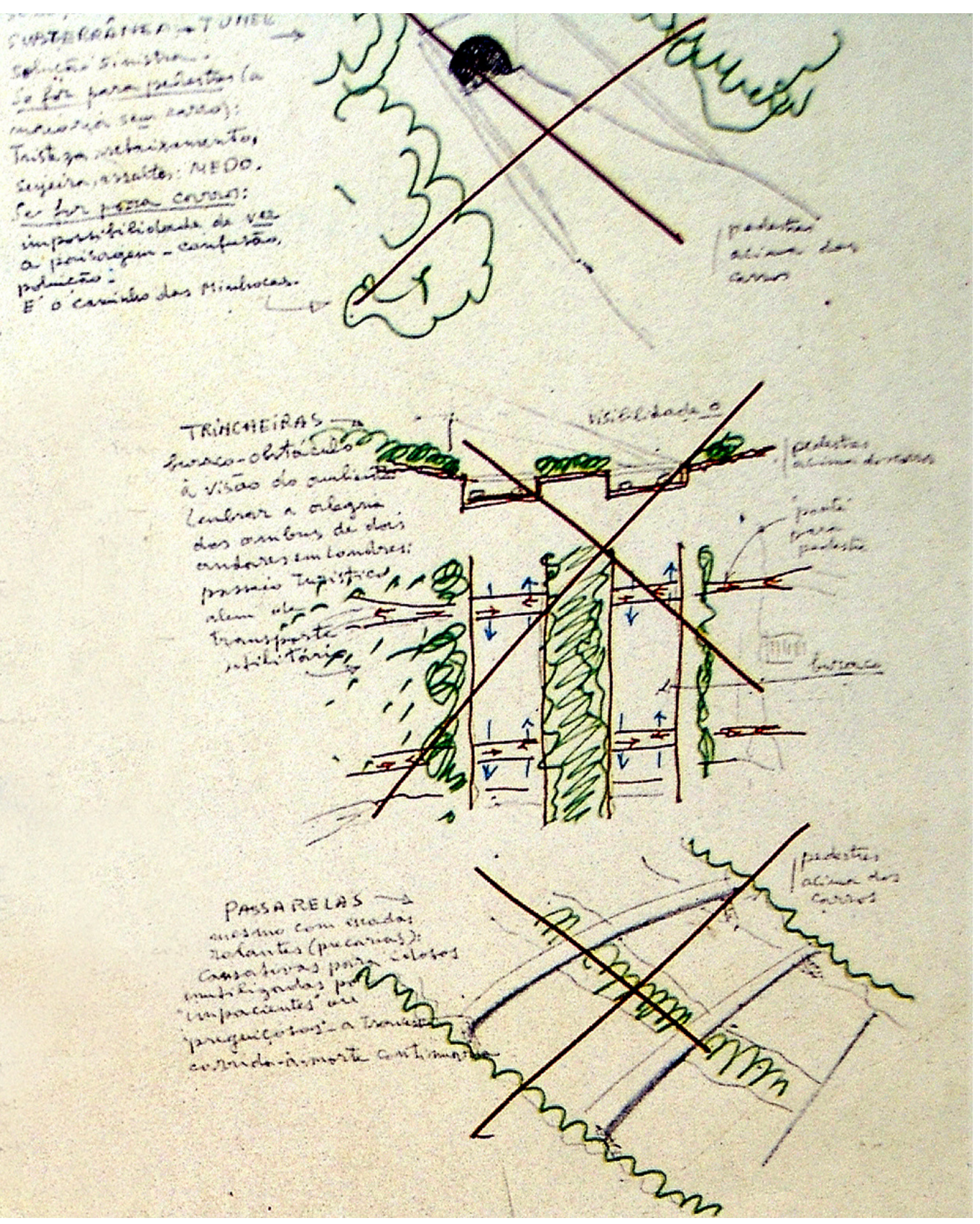

Fig. 61 Croqui de Lina mostrando as alternativas de transposição dos pedestres 
Assim, Lina "inverte" o foco da preocupação, colocando o usuário como elemento central na atualização da vocação do lugar e, talvez por isso, o projeto mostre-se solidário às questões percebidas desde o ponto de vista de quem caminha, de quem faz os percursos rápida ou lentamente por entre árvores, ou de quem está num lugar de encontro, ou seja, de quem efetivamente utiliza e vivencia o espaço, o habitante da cidade. Nota-se que a memória a ser preservada não é apenas aquela oficial, de grande valor artístico e histórico, mas também é a memória imaterial criada pelas relações individuais e coletivas durante os acontecimentos cotidianos da cidade. Esta memória não é concreta e fechada, mas fragmentada - "o narrador constrói planos contínuos (que se fragmentam constantemente) pela fusão de materiais de idades diferentes e de naturezas distintas (o que experimentou diretamente, o que ouviu contar, o que conhece por imagem...)"116.

Desta maneira, o procedimento do desenho busca mostrar muito mais o uso e narrar uma história que sobrepor folhas vegetais sobre mapas buscando a forma "ideal" do traçado.
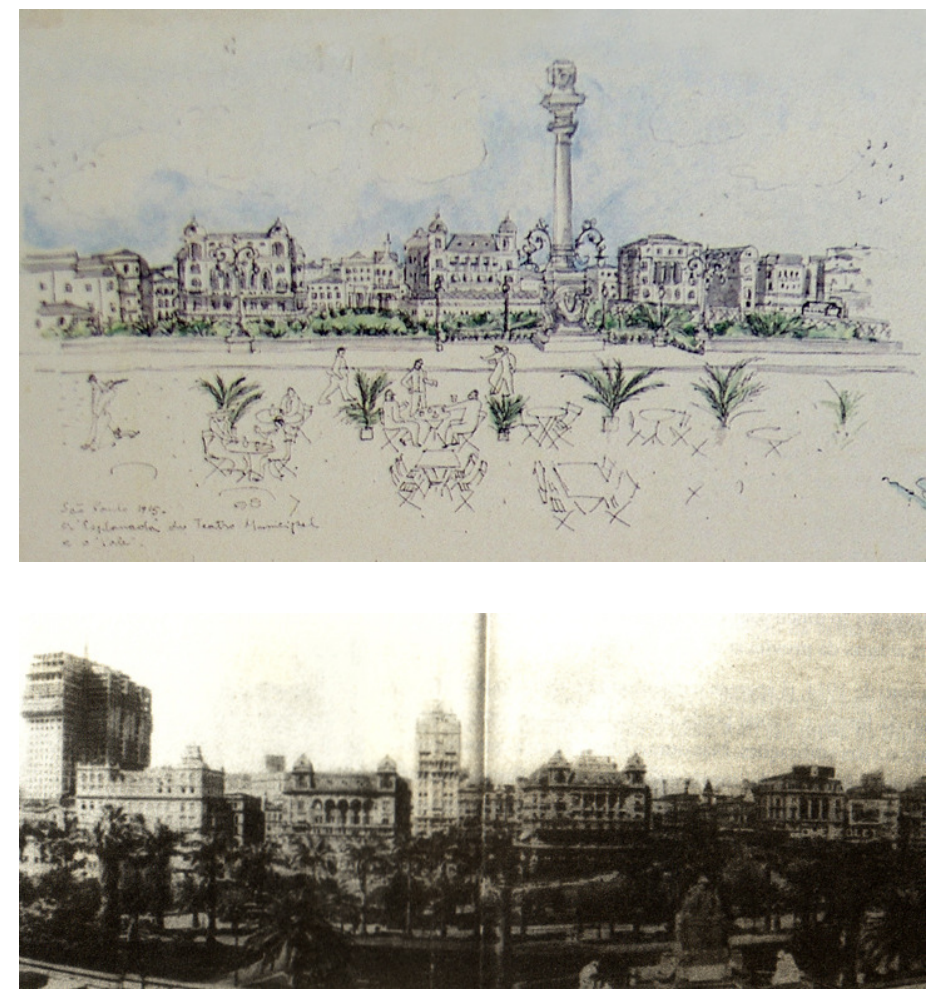

tecido urbano são incorporadas no percurso proposto pela arquiteta, como um Fig.60 Desenho de Lina. sistema de parques e espaços públicos. Os edifícios ganham novos usos, Fig.61 Foto do Anhangabaí no início do século XX.

Nos diversos croquis feitos pela arquiteta como material para estudo das características particulares do Vale do Anhangabaú, nota-se a tentativa de identificar sua vocação. $\mathrm{Na}$ aquarela que retrata a esplanada do Teatro Municipal, verifica-se que ela não corresponde à situação atual, mas nela misturam-se os vários tempos históricos que confluem para a sua configuração no presente, que, com este subterfúgio, mostra-se carregado de historicidade. A memória individual da arquiteta sobre o lugar, posta em ação, permite a visualização no presente dos diversos estratos temporais que situam historicamente este local específico. As praças antigas existentes no ${ }^{116}$ ARANTES, Antonio Augusto. Paisagens..., op.cit, p.20. 
ligados às antigas configurações espaciais, "nada deve ser modificado"117, afirma Lina. Esta afirmação lembra seus textos sobre os métodos usados na restauração dos casarões da Ladeira da Misericórdia e, portanto, podem-se admitir os mesmos procedimentos em São Paulo. Acredita-se que a valorização dos edifícios ligados à preservação da memória seguiria a mesma visão de Lina sobre os processos na proposta para o concurso, no entanto, o fato não é detalhado. 0 que se sabe é que estes edifícios antigos não são encarados como "relíquias", pois, se assim fossem tratados perderiam sua relação de afetividade com os cidadãos, como fantasmas de um passado já morto. Ao contrário, buscase aqui um passado revigorado pelo presente, ainda vivo.

O uso espontâneo do vale, a sua apropriação pelas pessoas, é visto como elemento importante para a nova configuração da área. Assim, o carrinho de pipoca, o churrasquinho, o vendedor de cata-vento, os barraqueiros, etc, são incorporados como elementos de projeto, pois pretende-se que sejam as próprias pessoas responsáveis por delimitar as novas áreas de encontro. Lina procura reforçar esta apropriação espontânea do lugar e para tanto propõe um parque com piso gramado, sem restrições de usos ou de caminhos, que podem ser escolhidos livremente.

"Um enorme gramado, como um campo de futebol, percorrido por caminhos naturais, isto é, aqueles escolhidos pelos transeuntes como mais rápidos e orgânicos, chegará até os pés dos grandes prédios. Sombra de árvores frondosas: tipuanas, seringueiras....palmeiras. Nada de grupinhos baixos, "esconderijos perigosos". Nada de paisagismo abstrato [...]. Bancos de pedra debaixo das árvores e muitos vendedores: pipocas, sorvetes, churrasquinhos, livros velhos e jornais novos, cataventos, brinquedos caseiros... será permitido pisar na grama [..." ${ }^{\prime \prime 18}$ (grifo do autor)

Desta forma, a resposta dada aos fluxos é bastante simples, mas ampla, pois assinala a devolução do espaço do vale ao pedestre para que escolha seus próprios caminhos. ${ }^{119}$. Assim, o desenho não faz restrições ao uso do espaço: é permitido pisar na grama e caminhar livremente, segundo as escolhas pessoais, sendo que os limites são estabelecidos cotidianamente numa complexa rede de relações sociais.

A solução dada ao espaço público do Vale do Anhangabaú enquanto

\footnotetext{
117 Expressão usada por Lina e que retoma suas explicações sobre os procedimentos do projeto para o Centro Histórico de Salvador. 118 FERRAZ, Marcelo. Dois..., op.cit.

119 Esta solução do coração da cidade fechado para o habitante em percurso é bastante popularizada durante o VIII CIAM.
} 
objeto representativo da memória coletiva configura-se pela articulação dos diversos usos ali presentes, sem nenhuma restrição. Os croquis de Lina são a expressão desta vontade, enquanto documentam situações diversas e narram histórias, mostrando a apropriação constante do vale pelas pessoas e evocando a possibilidade de um sentido de pertencimento coletivo ao lugar, nas mais diversas estratificações sociais.

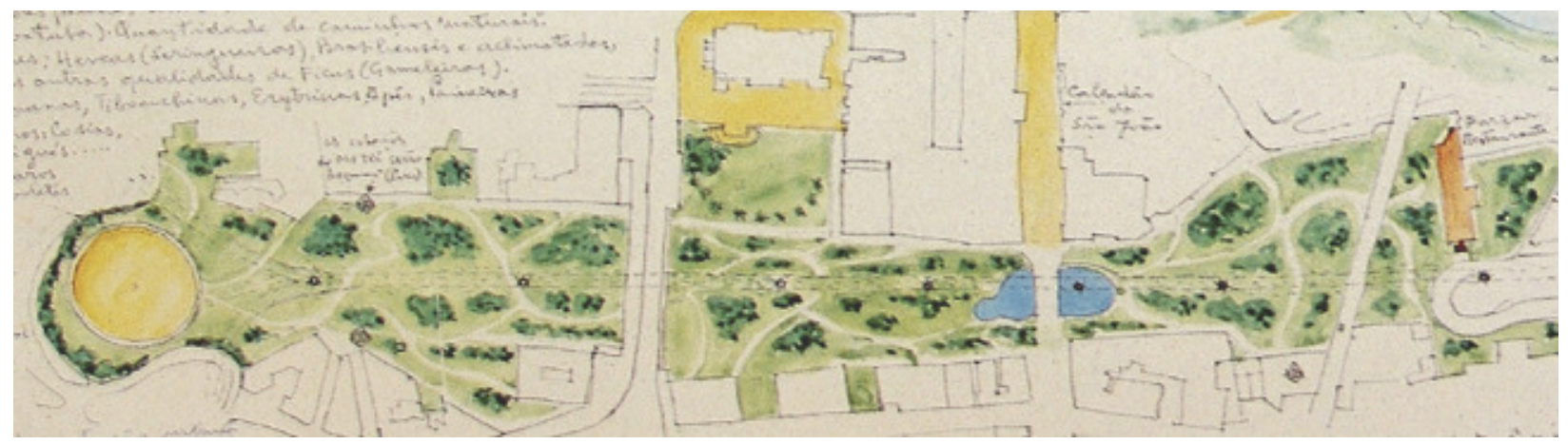

Fig.62 Desenho do parque apresentado no concurso.
É importante considerar a leitura do centro de São Paulo pelo pesquisador Antonio Augusto Arantes porque, segundo esta leitura, pode-se abarcar uma possivel análise de Lina e equipe ao que concerne ao mote da memória. No livro Paisagens Paulistanas, o autor tematiza os aspectos políticos e culturais da produção social do espaço público. Este enfoque parece importante na medida em que modifica a ênfase dada aos aspectos técnicos do trabalho de preservação da memória.

"[...] numa conjuntura em que diversos segmentos da sociedade brasileira amadurecem suas reivindicações de cidadania e consolidam estratégias de participação na esfera pública, impõe-se trazer à tona os processos por meio dos quais se constituem e se legitimam os marcos, lugares e cenários da memória social." 120

Conforme Arantes, entender este processo consiste em ampliar as iniciativas enquanto ações democráticas de pertencimento. Como estudo, podese considerar um momento significativo de reflexão para tal conduta - e não mera fórmula esquemática a ser empregada em gestões ou políticas culturais. Caberiam aos outros profissionais tais soluções, sempre lembrando que este é um trabalho paralelo e interdependente.

Através de entrevistas, Arantes mostra que existe uma "guerra de lugares", ou seja, existe uma fronteira que antagonicamente separa as práticas sociais, mas que estas são colocadas em diálogo e em contato num mesmo

${ }^{120}$ ARANTES, Antonio Augusto. Paisagens..., op.cit, p.9. 
espaço. No espaço cotidiano, são construídas fronteiras e limites simbólicos que hierarquizam e ordenam os grupos sociais, entrecruzando-se de modo bastante complexo. Os lugares mais representativos da cidade de São Paulo reorganizam constantemente as tensões e conflitos sociais: ora são locais de passagem, de encontro, de manifestações políticas e reivindicações de direitos, de assaltos, de comércio de drogas, de atividades formais e informais, de exibição, de mendicância, de turismo, de pregações religiosas, etc. Dessa maneira, não existe um claro limite simplesmente colocado lado a lado ou justaposto, mas existe um entrelaçamento, formando "zonas simbólicas de transição", que não se define e não se uniformiza. A contradição ilustra o diálogo.

O caminhar pela cidade propicia a criação e a constante recriação destas fronteiras. Implica na apropriação do sistema topográfico e implica também numa atuação, ou seja, numa tomada de posição durante o desafio de enfrentar os limites postos pelos usos diversos. "Neste sentido, caminhar pela cidade é decifrar aos poucos, e pelo movimento, um palimpsesto."121 Sobre os marcos construídos da cidade: "os marcos visíveis que perduram, lugares de identidade, são apenas parte de uma realidade mais profunda e mais extensa que os contextualiza e desafia."122

Arantes então configura a cidade de São Paulo sob outro aspecto, através de um complexo agregado de tensões que faz parte de um outro modo de representação do centro. Praças e monumentos oficiais não são indiferentes a estas representações, mas dão um aspecto particular e até necessário à própria sobrevivência. Dessa forma, coloca o problema e repudia as ações dos planos disciplinadores dos usos, como o traçado urbano resultante de iniciativas que ignoram a realidade local, ou mesmo, as ações de segurança. De que forma se pode considerar democraticamente as diferenças? "Até que ponto é possivel acomodar a diversidade cultural no interior de uma mesma "moldura política'?"123 Arantes evidencia a fragmentação da cidade que é pouco considerada nos projetos, o que compromete a consolidação das formas democráticas de gestão e afirmação das políticas culturais.

A proposta de Lina e a visão de Arantes sobre o centro de São Paulo

\footnotetext{
121 Idem, p.121.

122 Idem, p.122.

123 Idem, p.139.
} 
parecem bastante aproximadas, uma vez que os monumentos ou marcos referenciais da cidade não interessam enquanto portadores de um significado simbólico cristalizado. Ambos aceitam que os processos culturais e simbólicos nacionais produzidos sejam modificados pelas pessoas comuns, no cotidiano. Conforme indica Arantes: "Interessa-me o estudo da preservação do patrimônio como 'prática social' e compreender de que modo essa prática participa da formação do espaço público"124.Nesta visão o trabalho de Lina de "dar forma", ou criar uma nova situação parte de um dado existente, que no caso de São Paulo, conforme a observação de Arantes, está longe de ser coerente, homogênea e tranqüila. A proposta de Lina não deseja criar fórmulas herméticas ou subsidiar soluções fechadas de preservação, mas admite uma liberdade através da observação consciente das estruturas existentes. A oposição entre 0 antigo e 0 novo se desfaz a partir do processo de criação da arquiteta onde 0 existente dá limites e sentidos para o novo; bem como o novo procura atualizar o valor do antigo. Tudo isso só é percebido pela inversão do problema colocado pelo concurso, ou seja, a arquiteta resolve o problema da circulação e organização do vale somado ao que considera importante naquele lugar: sua vocação de encontro e sociabilidade, seu valor histórico, simbólico e paisagístico. A relação entre permanência e inovação se dá através de um preparo histórico-crítico explicado pelas condições esboçadas durante 0 trabalho, principalmente através de sua formação e experiência profissional e as relações estabelecidas entre 0 antigo e o novo nesta trajetória.

Vale destacar aqui que a proposta de análise dos dois objetos empíricos ganham dimensões diversas pelas próprias condições colocadas a priori. 0 projeto de Lina para o Centro Histórico de Salvador tem uma leitura pautada principalmente nas questões sobre as intervenções em conjuntos históricos suscitadas pelos debates da restauração, pois, o grande problema colocado advém do aspecto cultural existente neste tipo de intervenção. Por outro lado, o projeto para o Concurso: Vale do Anhangabaú é analisado pelo viés da retomada das discussões colocadas pelos arquitetos e urbanistas do segundo pós-guerra, uma vez que o objeto de intervenção propõe, sobretudo, uma solução urbanística. Neste percurso é possivel apontar os momentos de aproximação das disciplinas sobre a relação entre o antigo e o novo, suas nuances históricas,

124 Idem, p.9-10. 
especificidades, especialmente, considerando a trajetória da arquiteta Lina.

Além desta condição apontada, cabe colocar que o projeto para 0 Centro Histórico de Salvador permite uma leitura mais avançada uma vez o material existente sobre o projeto é muito mais completo, e principalmente, porque existem partes do projeto executadas e, assim, é passível de verificação e comparação entre o plano teórico e prático. É importante considerar a execução do projeto no trabalho de Lina porque grande parte das soluções é resolvida no canteiro de obras. Acredita-se que esta verificação in loco, no trabalho da arquiteta, seja algo fundamental, uma vez que, a representação do projeto apresenta-se através de desenhos muitas vezes "livres" e "poéticos", apesar do rigor sustentado pela arquiteta na adoção de todas as cotas, medidas, técnicas construtivas, materiais e etc. Além disso, considera-se que algumas propostas são "surpreendentes", pelo estranhamento provocado pelo desenho ou mesmo pela escolha da técnica construtiva. Deparar-se com os croquis do MASP e não conhecê-lo construído pode ser motivo de dúvida quanto a sua real efetivação. 0 mesmo ocorre com a técnica construtiva industrial usada para a restauração dos casarões coloniais do Centro Histórico de Salvador. É dessa maneira que se podem justificar as diferentes abordagens e 0 aprofundamento analítico dos dois objetos de intervenção. Espera-se que, através dos enfoques diversos durante as análises, possam-se construir os diálogos estabelecidos entre as disciplinas durante a atuação da arquiteta, principalmente, quando 0 tema consiste na relação estabelecida entre o antigo e o novo. 


\section{- considerações finais}

As considerações colocadas adiante não têm a intenção de sugerir um fim ao assunto aqui desenvolvido, uma vez que, durante a empreitada da pesquisa, o tema da relação entre o antigo e o novo em intervenções em lugares considerados marcos referenciais da cidade mostrou-se extremamente complexo, principalmente pelos diálogos estabelecidos entre as disciplinas da arquitetura, do urbanismo e do restauro. Este diálogo, considerado importante momento de discussão durante 0 processo das intervenções em estruturas preexistentes, ainda está muito longe de acontecer de fato, uma vez que efetivamente não existe um aprofundamento nos meandros do trabalho interdisciplinar, pelo menos no Brasil. É dessa forma então que se pretende apenas retomar alguns pontos relevantes do tema, sobretudo considerando os objetos empíricos tratados e a própria trajetória da arquiteta aqui analisada.

Através da observação dos dois projetos de intervenção da década de 1980 desenvolvidos por Lina no Brasil, o Centro Histórico de Salvador e o Concurso: Vale do Anhangabaú, entendeu-se que seria necessário debruçar-se sobre os procedimentos usados pela arquiteta durante seu ato projetual, a fim de apreender os projetos mais a fundo e não apenas considerá-los através de uma leitura simplesmente formal. Portanto, a preocupação durante 0 trabalho foi procurar compreender as relações estabelecidas por Lina, com 0 intuito de esclarecer seu procedimento, principalmente no que diz respeito ao diálogo estabelecido entre permanência e inovação. Vale dizer que esta leitura sobre as relações estabelecidas pelo arquiteto é uma sugestão de análise emprestada das considerações sobre a geração dos arquitetos do segundo pós-guerra (geração da qual Lina faz parte), uma vez que a noção de "relação" passa a ser uma possibilidade de discussão das novas formas de consideração do espaço público que não aquela procedente da rigidez formal do funcionalismo arquitetônico ${ }^{1}$. O intuito desta geração de arquitetos do pós-guerra em devolver à cidade seu valor simbólico e cultural, além de gerar a revisão dos procedimentos de projeto, promove também a revisão de algumas noções, na maior parte,

\footnotetext{
${ }^{1}$ BARONE, Ana Claudia Castilho. Op.cit., p.54.
} 
categorias intrínsecas à prática da preservação, como, a noção de "memória", "história", "monumentalidade", "preexistência", etc.

Por outro lado, nesse mesmo período, a própria investida sobre a restauração ganha novos enfoques e ampliações, dentre os quais destaca-se a necessidade de considerar o tempo presente e o uso das novas tecnologias e linguagens durante 0 ato de intervir. Considerando a revisão sobre a noção de "história" e "tempo" nestes dois sentidos, do presente para o passado e do passado para o presente, os campos de atuação tanto na arquitetura, no urbanismo ou no restauro encontram-se num movimento de aproximação e diálogo na relação entre 0 antigo e o novo.

Estas novas relações apontadas aqui como preocupação da geração dos arquitetos do pós-guerra passam a fazer parte do repertório dos arquitetos brasileiros na década de 1980, os quais passam a criticar os critérios abstratos de concepção da cidade funcional dentro de parâmetros estabelecidos por um grupo hegemônico, que conduzira a maior parte do debate no âmbito dos CIAM's. Além da preocupação com a democratização do debate sobre a arquitetura, que de certa forma rompe com a visão universal e normativa do CIAM, esta geração manipula algumas noções referentes ao tema proposto pela pesquisa, como a relevância da preexistência como "baliza" da criatividade do arquiteto moderno - preexistência no sentido amplo, relacionado aos aspectos físicos e materiais existentes, bem como aos valores simbólicos e sentimentais envolvidos. Também neste momento, na esfera do nosso serviço de tutela do patrimônio, há uma revisão das noções que envolvem a prática de preservação, principalmente quanto ao que diz respeito às formas seleção dos bens a serem preservados, aos meios pragmáticos de preservação, bem como à busca da ampliação da representatividade durante o processo. Com isso, há também uma ampliação da noção de cultura, o que se reflete inclusive sobre as políticas culturais.

Dessa forma, a análise das relações percorridas no trabalho da arquiteta Lina contribuiu também para compreender o próprio momento de abertura política da década de 1980 e o que isso significou para a arquitetura daquele momento no Brasil. A entrada da participação democrática incide consideravelmente nas discussões sobre o espaço público, na ampliação da 
noção de cultura e das próprias políticas culturais, o que tem reverberações sobre o modo de atuação dos arquitetos.

No caso específico de Lina, o procedimento torna-se coerente com 0 discurso, uma vez que a arquiteta estabelece algumas apropriações de noções ou metodologias já em evidência durante toda sua formação propedêutica e também em sua experiência profissional, revelando alguns caminhos sobre 0 possível diálogo entre o antigo e o novo, colocados sob análise no decorrer da pesquisa: sua formação romana sobre os preceitos giovannonianos e a adesão às articulações entre as novas necessidades de usos e os valores herdados do sítio histórico durante as intervenções urbanas; a preocupação, na Itália, em criar-se subsídios para abrir a possibilidade de uma nova percepção estética no homem moderno - a começar com o desenvolvimento das formas expositivas, passando pela museologia e terminando na inserção do elemento novo na cidade antiga; a referência à cultura popular como repertório simbólico e cultural específico de uma determinada localidade na busca de novas soluções. Também não se pode deixar de lado a apropriação de algumas metodologias do projeto de restauro, principalmente aquelas decorrentes da escola do restauro crítico e que tem como fim último a própria Carta de Veneza, instrumento muitas vezes referenciado por Lina. Sobre este aspecto, apresentou-se a hipótese da constante interlocução com Bruno Zevi como forma de atualidade da arquiteta sobre os procedimentos e métodos utilizados nas intervenções em sítios históricos.

Com isso, o trabalho preocupou-se em buscar as referências teóricas usadas pela arquiteta - as quais não aparecem diretamente em suas considerações -, além de entender o contexto político e cultural em que está inserida, a fim de questionar algumas afirmações da bibliografia procedente que consideram Lina "inventora" de certos preceitos ou noções teóricas ou mesmo insistem na tarefa de enquadrar ou classificá-la em determinadas vertentes da arquitetura ou do restauro. Como foi colocado, poucas são as contribuições da iniciativa de classificar o trabalho de Lina segundo uma ou outra linha de intervenção. $O$ intuito principal é acompanhar e compreender o limite estabelecido pela arquiteta durante seu procedimento criativo e sua trajetória.

Conforme foi apontado, hoje não existe a visão que rejeite a inserção do novo em ambientes antigos durante as intervenções. Esta aceitação do novo 
vem dotar a cidade de dinâmicas atuais e contribuir para que a cidade não entre num processo de inércia e de cristalização ou, para citar um termo usado durante a pesquisa, de "musealização". No entanto, a abertura ao novo de forma deliberada sem que haja um método coerente acaba provocando alguns danos irreversíveis, principalmente sobre a parte mais frágil, a antiga, devido à constante arbitrariedade ou experimentação dos arquitetos perante esta aparente "liberdade" criativa. Entre a proposição da destruição do antigo para a inserção do novo e o movimento de proteção a todo custo inseriu-se a versão partidária da conciliação e do diálogo entre ambas as partes, segundo uma metodologia científica aplicada, que se encontra, sobretudo, no âmbito das metodologias de restauração. Não resta dúvida que a deontologia profissional da disciplina na Teoria da Restauração vem contribuir para esta discussão, uma vez que as iniciativas de se considerar o diálogo entre 0 antigo e o novo sem uma metodologia científica acabam construindo justificativas sobre termos absolutamente genéricos, como "tem qualidade", "é respeitoso", "conserva o sentido", etc, ou tomam como categoria objetiva critérios decorrentes das normas e leis de implantação ou zoneamento urbano (ou mesmo dos Planos Diretores) regras, porém, que não são categorias que justificam ações no âmbito das intervenções em locais considerados importantes referências culturais. A noção de restauro como ato cultural acaba justificando a pertinência de Lina em aproximar-se de alguns métodos da disciplina do restauro, uma vez que se reforça a idéia da intervenção relacionada às exigências da memória mais que qualquer hipótese de cunho meramente prático, muitas vezes vinculada aos anseios empreendedores da especulação imobiliária ou da indústria turística.

Considerar uma metodologia científica não significa seguir linhas ou vertentes, mas significa posicionar-se criticamente através de um preparo no campo da história artística e arquitetônica e atuar segundo a orientação técnica adequada. Não significa anular a criatividade e as novas soluções, mas particularizar cada caso segundo o aporte da conservação. Este procedimento pode ser verificado no Centro Histórico de Salvador, quando Lina lança mão do uso da tecnologia industrial durante o projeto de restauração. Apesar do uso de uma tecnologia padronizada a arquiteta reafirma, durante o procedimento, a importância do valor cultural no momento em que particulariza as soluções no canteiro de obras. 
Entretanto, observando alguns procedimentos vinculados ao restauro, sob os aspectos da importância do trabalho interdisciplinar, da documentação das etapas envolvidas, da precisão documental e gráfica, da publicação das ações, etc, percebe-se que o procedimento de Lina é muito mais empírico, no sentido de que suas ações são decorrentes de um julgamento individual e da interpretação pessoal, e não de um trabalho de pesquisa interdisciplinar.

É importante colocar também que 0 aporte da conservação no trabalho da arquiteta tem muito mais aproximação com a tentativa de se criar um movimento cultural, ou seja, de dar possibilidade à leitura e à percepção imediata daquele que vê a obra, criando um questionamento ou um posicionamento crítico frente às questões de cunho cultural do que seguir uma determinada vertente do restauro. Isso fica evidente nas propostas pedagógicas dos museus (MASP, MAMB, MAP), na escola de design proposta no Solar do Unhão e efetivamente nas intervenções analisadas. Assim, o foco principal está muito mais voltado para a percepção do homem que para 0 objeto em si. 0 monumento então extrapola a consideração apenas estético-histórica e acaba abrangendo valores subjetivos, como o valor simbólico e sentimental.

Esta definição de monumento e o desvio da atenção para a sua percepção aproximam Lina da reflexão elaborada pelo austríaco Alois Riegl, uma vez que este empreende uma reflexão não sobre as metodologias da prática em si do restauro, mas sim sobre o valor outorgado ao monumento. A aceitação de que estes valores são relativos e satisfazem um desejo artístico de uma determinada sociedade e época garante uma posição respeitosa perante as várias formas de trabalhar a proposição do diálogo e a convivência entre o antigo e o novo em cada período. A relativização dos valores é exatamente a interlocução entre a nova forma de se pensar a conservação dos monumentos e a renovação da disciplina histórica, não mais como seqüência de estilos ou datas, mas como exame crítico. ${ }^{2}$ A consideração dos valores simbólicos e sentimentais durante a intervenção sobre o monumento - ambos evocados pelo

\footnotetext{
2 Conforme as considerações sobre "presente histórico" na Parte 1 desta pesquisa, mostrou-se através do autor Ignasi de Solà-Morales que alguns ensaios dos arquitetos do segundo pós-guerra também consideram a convivência entre 0 antigo e o novo enriquecida por meio da compreensão das mudanças da sensibilidade ou das categorias visuais, método similar ao processo usado por Aloïs Riegl na história da arte.
} 
valor de antiguidade - é também uma forma de apontar a aproximação com o método riegliano, uma vez que o procedimento utiliza-se do contraste e da diferença entre 0 antigo e o novo com 0 intuito de possibilitar a leitura de forma imediata por qualquer tipo de pessoa (erudita ou não). Novamente, nota-se que 0 procedimento de Lina está diretamente ligado a esta intenção de criar questionamentos perante a visão do contraste entre formas do presente e do passado.

Levar em conta as várias estratificações identificáveis no monumento não significa apenas um procedimento de datação das várias intervenções, mas tem como intuito respeitar as várias fases de intervenção humana, tornando legíveis as marcas, as "práticas sociais", as quais são geralmente escamoteadas no processo de restituição estilística do edifício. É dessa maneira que Lina aceita o fato de que os processos culturais e simbólicos produzidos são modificados constantemente no cotidiano da cidade e que isto também deve ser considerado durante o procedimento.

Também a questão do uso entra como dado importante durante o sua atuação, através da vinculação direta com as relações estabelecidas naquele cotidiano particular. 0 uso espontâneo do espaço público na cidade é incorporado no projeto de Lina como programa, o que aparece como ponto fundamental da metodologia usada pela arquiteta, sendo também identificado como procedimento coerente com o discurso preconizado na década de 1980 sobre a humanização e a participação nos espaços públicos e a ampliação da noção de preservação e cultura. Acredita-se que a observação do uso existente e sua consideração como programa possibilita tornar intrínsecas, durante 0 ato projetual, noções que parecem bastante externas ao desenho arquitetônico, como a questão da "prática social", da "vocação do lugar", da "preexistência" ou da "espontaneidade". Em suma, o uso é um instrumento usado como meio de perpetuação do objetivo cultural e, consequentemente, para o êxito da preservação do conjunto.

Por fim, é importante considerar como as questões sobre a memória coletiva, a participação e a cultura local são garantidas pelos meios projetuais e não por iniciativas paternalistas ou normativas pós-intervenção. Os lugares imaginados por Lina não precisam ser consagrados como "lugares da memória" por normas ou leis, porque no processo proposto eles o são naturalmente. A 
proposição de Lina vem questionar as iniciativas que prezam apenas pelo tombamento do órgão oficial de tutela como instrumento de preservação, além de provocar a discussão sobre a forma especializada de condução dos projetos de restauro no Brasil. Provoca também uma outra postura frente à responsabilidade do arquiteto, questionando sua própria formação, a qual cada vez menos oferece caminhos para guiar as intervenções através de um juízo histórico-crítico.

O caminho proposto por Lina é alheio ao processo "oficial", mas nem por isso deixa de ser importante, principalmente por oferecer a alternativa de uma atuação mais coerente em relação às ampliações ocorridas na década de 1980, no Brasil, no âmbito das noções de cultura, preservação e memória, e também por tomar parte à própria ampliação democrática da participação decisória no processo de formação e consolidação do espaço público. 
- bibliografia

AMADO, Jorge. Jorge Amado e o Pelourinho. Revista Projeto, n. 142, jan-fev, 1992, p.46.

ANDRADE, Rodrigo Melo Franco de. Rodrigo e o SPHAN. Rio de Janeiro: Ministério da Cultura, Fundação Nacional Pró-Memória, 1987.

ANDRADE, Antonio Luiz Dias de. Um estado completo que pode jamais ter existido. Tese de Doutorado apresentada à Faculdade de Arquitetura e Urbanismo da Universidade de São Paulo (FAUUSP). São Paulo, 1993.

ANELLI, Renato Luiz Sobral. Interlocução com a arquitetura italiana na constituição da arquitetura moderna em São Paulo. Texto de sistematização da produção científica para o Concurso de Livre Docência - Escola de Engenharia de São Carlos da Universidade de São Paulo. São Paulo, 2001.

ANOTAÇÕES SOBRE O CONCURSO. Arquivo de croquis e anotações. Instituto Lina Bo e P. M. Bardi.

ARANTES, Antonio Augusto (org.). Produzindo o passado: estratégias de construção do patrimônio cultural. São Paulo: Ed. Brasiliense, 1984.

Documentos históricos, documentos da cultura. Revista do Patrimônio Histórico Artístico Nacional, n.22, pp.48-55, 1987. . Paisagens Paulistanas. São Paulo: Imprensa Oficial, 2000.

ARANTES, Otilia. O lugar da arquitetura depois dos modernos. São Paulo: Edusp, 2000.

ARGAN, Giulio Carlo. História da Arte como História da Cidade. São Paulo: Martins Fontes, 1998.

. Arte Moderna. São Paulo: Companhia das Letras, 1992.

BARBARA, Fernanda; OTONDO, Catherine. Sobre uma arquitetura. Revista Caramelo. São Paulo, n.4, pp.78-81, 1992

BARDI, Lina Bo. A Catedral. Habitat, n.14, jan-fev, 1954. . Apresentação - Manifesto da Exposição de Arte Popular do Unhão. Revista Mirantes das Artes, n.6, nov, 1967.

. Cinco anos entre os brancos: o Museu de Arte Moderna da Bahia. Revista Caramelo, São Paulo, n.4, 1998. Publicado originalmente na Revista Mirantes das Artes, n.6, novembro de 1967.

Contribuição Propedêutica ao Ensino da Teoria da Arquitetura. São Paulo: Instituto Lina Bo e P. M. Bardi, 2002. (original tese apresentada no concurso da cadeira de Teoria da Arquitetura e Urbanismo da Universidade de São Paulo), setembro de 1957.

. Ladeira da Misericórdia. Revista Projeto, São Paulo, n.142, jan-fev, 1992.

. Lina Bo Bardi arquiteto. São Paulo: Instituto Lina Bo e P.M. Bardi, 2006, 48p.Catálogo de exposição, São Paulo, MASP. Na Europa a casa do homem ruiu. Rio, n.92, fev, 1947.

. Os museus vivos nos Estados Unidos. Revista Habitat, n.8, pp.12-15, 1950.

. Programa do Curso de extensão Universitária. São Paulo. Instituto Lina Bo Bardi e P. M. Bardi. (s.d.)

. Tempos de Grossura: o design no impasse. São Paulo: Instituto Lina Bo e P. M. Bardi, 1994.

. Uma aula de arquitetura Revista Projeto, São Paulo, n.142, jan-fev, 1992.

BARONE, Ana Claudia. Team 10: arquitetura como crítica. São Paulo: Annablume; FAPESP, 2002.

BIERRENBACH, Ana Carolina. Lina Bo Bardi: tempo, história e restauro. Revista CPC, n.3, nov/2007 abril/2006, p.6-32. Disponivel em: http://www.usp.br/cpc/v1/php/wf07_revista_interna.php?id_revista=7\&id_conteu $\mathrm{do}=18 \&$ tipo $=5$. Acesso dia 11/12/2006. 
Os restauros de Lina Bo Bardi e as interpretações da história. Dissertação de Mestrado - UFBA. Salvador, 2001.

BOITO, Camilo. Os Restauradores. São Paulo: Ateliê Editorial, 2002.

BOSI, Ecléa. Memória e sociedade: lembrança de velhos. São Paulo: T. A Queiroz Editora, 1979.

. O tempo vivo da memória: ensaios de psicologia social. São Paulo: Ateliê, 2003.

BOSI, Vera. Participação e pesquisa na preservação do patrimônio cultural. In: Revista do Patrimônio Histórico Artístico Nacional, n.22, pp.138-144, 1987.

BRANDI, Cesare. Processo all'architettura moderna. L'Architettura, cronache e storia, n.II, pp.356-60, 1956. . Teoria da Restauração. São Paulo: Ateliê Editorial, 2004.

CABRAL, Maria Cristina Nascentes. Racionalismo arquitetônico de Lina Bo Bardi. Dissertação de mestrado desenvolvida na PUC-RJ. Rio de Janeiro, 1996.

CAMPELLO, M. de Fátima de M. Barreto. Lina Bo Bardi: as moradas da alma. Dissertação de mestrado desenvolvida na escola de Engenharia de São Carlos (USP- São Carlos). São Carlos, 1997.

CARBONARA, Giovanni. Architettura e restauro oggi a confronto. Palladio, n.35, 2005. . Avvicinamento al restauro. Napoli: Linguori, 1997.

Carta de Veneza. In: Cartas Patrimoniais. Rio de Janeiro: IPHAN, 2000, p.94.

CASTRO, Sonia Rabello de. O estado da preservação de bens culturais: o tombamento. Rio de Janeiro: Renovar, 1991.

CAVALCANTI, Lauro. Modernistas na Repartição. Rio de Janeiro: UFRJ; IPHAN, 2000, (2ed). . O cidadão moderno. In: Revista do Patrimônio Histórico e artístico nacional, n.24, pp.106-115, 1996.

CIUCCI, Giorgio. Gli architetti e il fascismo: architettura e città 1922-1944. Torino: Giulio Einaudi Editore, 1989.

COHN, Gabriel. Concepção oficial de cultura e o processo cultural. Revista do Patrimônio Histórico e Artístico Nacional, n.22, pp. 7-10, 1987.

CORBUSIER, Le. Precisões sobre um estado presente da arquitetura e do urbanismo. São Paulo: Cosac \& Naify, 2004. . Urbanismo. São Paulo: Editora Martins Fontes, 1992.

COSTA, Lucio. Documentação Necessária. Arquitetura Civil II. São Paulo: FAUUSP, MEC/IPHAN, 1975.

CUNHA, Claudia dos Reis e. O patrimônio Cultural da cidade de Sorocaba: análise de uma trajetória. Dissertação de Mestrado apresentada à Faculdade de Arquitetura e Urbanismo da Universidade de São Paulo. São Paulo, 2005.

CUNHA, Maria Clementina Pereira (org.). 0 direito à memória. São Paulo: Brasil/Printed, 1991.

CHAGAS, Maurício de Almeida. Modernismo e tradição: Lina Bo Bardi na Bahia. Dissertação de Mestrado da área de Desenho Urbano apresentada na Faculdade de Arquitetura e Urbanismo da Universidade Ferdaral da Bahia (UFBA). Salvador, 2002, 244p.

CHOAY, Françoise. A Alegoria do Patrimônio. São Paulo: Estação Liberdade/Ed. Unesp, 2001. . O Urbanismo. São Paulo: Editora Perspectiva, 1997.

GRAMSCI, Antonio. Obras escolhidas. São Paulo: Martins Fontes, 1978.

D'ÁLESSIO, Márcia Mansor. Memória: Leituras de M. Halbwachs e P. Nora. In: Revista Brasileira de História. São Paulo, v.13, n,25-26, set., 1993.

FERNANDES, Antônio Sergio. Empresarialismo urbano em Salvador: a recuperação do Centro Histórico do Pelourinho. Dissertação de mestrado em Desenvolvimento Urbano na Universidade Federal de Pernabuco (UFPE). Pernambuco, 1998.

FERRAZ, Marcelo Carvalho. Dois concursos: dois manifestos. Revista Caramelo. São Paulo, n.4, 1992. 
(org). Lina Bo Bardi. São Paulo: Empresa das Artes; Instituto Lina Bo e P.M. Bardi, 1993.

FONSECA, Maria Cecília Londres. O patrimônio em processo. Rio de Janeiro: UFRJ/Iphan, 2005.

FONTANELE, Sabrina Studart. Intervenções na cidade existente: um estudo sobre o centro Dragão do Mar e a praia de Iracema. Dissertação de mestrado desenvolvida na Faculdade de Arquitetura e Urbanismo da Universidade de São Paulo (FAU-USP). São Paulo, 2004.

FREIRE, Cristina. Além dos mapas: os monumentos no imaginário urbano contemporâneo. São Paulo: SESC; Annablume, 1997

GIEDION, Siegfried. Arquitectura y Comunidad. Buenos Aires: Ediciones Nueva Vision, 1963.

Space, Time and Architecture, the growth of a new tradition. Harvard University Press. Cambridge, 1941.

GIOVANNONI, Gustavo. Questioni di architettura nella storia e nella vita. Roma: Società Editrice d'Arte Illustrata, 1925.

. Proposte di sistemazione edilizia del quartiere del rinascimento in Roma, 1916. . Vecchie città ed edilizia nuova. In: Nuova Antologia, 1913, p.450. . Vecchie città ed edilizia nuova. Torino: Editrice Torinese, 193.

GOMES, Marco A de Filgueiras (org.) Pelo Pelô. História Cultura e cidade. Salvador: EDUFBA, 1995.

GONÇALVES, Cristiane Souza. Metodologia para a Restauração Arquitetônica: A Experiência do Serviço do Patrimônio Histórico e Artístico Nacional em São Paulo, 1937-1975 (Dissertação de Mestrado- Faculdade de Arquitetura e Urbanismo/USP). São Paulo, 2004.

GUEDES, Joaquim. Lembranças de Lina Bo Bardi. Revista Caramelo. São Paulo, n.4, 1992.

HALBWACHS, Maurice. A memória coletiva. São Paulo: Vértice, 1990.

JEUDY, Henri-Pierre. Espelhos das cidades. Rio de Janeiro: Casa da Palavra, 2005, p.108. Cf. Jeudy. . Memória do social. Rio de Janeiro: Forense Universitária, 1990.

KLIASS, Rosa Grená; KFOURI, Jamil José. Diversidade de formas. Arquitetura e Urbanismo. São Paulo, n.42, jun-julh, 1992, p.40.

KÜHL, Beatriz Mugayar. História e Ética na Conservação e na Restauração de Monumentos Históricos. Revista CPC, v.1, n.1, nov.2005 - abr.2006. Disponível em: http://www.usp.br/cpc. Acesso em 27 maio de 2006.

O tratamento das superfícies arquitetônicas como problema teórico da restauração. Anais do Museu Paulista, v.2, jan-dez, , p.309- 330, 2004.

LATORRACA, Giancarlo (org.). João Filgueiras Lima. Portugal: Editora Blau/ Instituto Lina Bo e P. M. Bardi, 2000.

LE GOFF, Jacques. História e Memória. Campinas: Editora Unicamp, 2003. . Memória e História. Enciclopédia Einaldi, p.162.

Por amor às cidades: conversações com Jean Lebrun. São Paulo: Editora Unesp, 1998.

LEITE, Rogério Proença. Contra usos da cidade: lugares e espaço público na experiência urbana contemporânea. Campinas: Editora Unicamp, 2004.

LEME, Maria Cristina da Silva. A formação do pensamento urbanístico no Brasil. 18951965. São Paulo: Nobel/FAU-USP/FUPAM, 1999. . A formação do pensamento urbanístico, em São Paulo, no início do século XX. Espaço e Debates, n.34, pp.64- 70,1991.

LEPETIT, Bernard. Por uma Nova História Urbana. São Paulo: Editora da Universidade de São Paulo, 2001.

MACHADO, Denise Barcelos Pinheiro; PEREIRA, Margareth da Silva; SILVA, Rachel Coutinho (org.). Urbanismo em questão. Rio de Janeiro: UFRJ/PROURB, 2003. 
MAGALHÃES, Aloísio. E triunfo? A questão dos bens culturais no Brasil. Rio de Janeiro: Nova Fronteira; Brasília: UnB, 1987.

MENESES, Ulpiano T. B. A História, cativa da memória? Revista do Instituto de Estudos Brasileiros, v. 34, pp. 9-23, 1992. . A paisagem como fato cultural. In: Turismo e paisagem. Rio de Janeiro: Contexto, 2002.

MICELI, Sergio. Refrigério da cultura oficial. In: Revista do Patrimônio Histórico Artístico Nacional, n.22, p.44-47, 1987.

MOLINARI, Luca. Entre continuidad y crisis. Historia y proyecto em la cultura arquitectónica italiana de la posguerra. Revista $2 \mathrm{G}$ ( Arquitectura Italiana de la posguerra: 1944-1960), n.15, pp.4-11,.2000.

MONNET, Jérôme. O álibi do patrimônio: crise da cidade, gestão urbana e nostalgia do passado. In: Revista do Patrimônio Histórico e artístico nacional, n.24, pp.220228, 1996.

MOTTA, Lia. A Sphan em Ouro Preto: uma história de conceitos e critérios. In: Revista do Patrimônio Histórico Artístico e Nacional, n.22, pp.108-122, 1987.

NOBRE, Eduardo Alberto Cusce. Intervenções urbanas em Salvador: turismo e "gentrificação" no processo de renovação urbana no Pelourinho. Belo Horizonte: Ampur, pp.1-11, 2003.

NORA, Pierre. Entre memória e história: a problemática dos lugares. In: Projeto História: Revista do Programa de Estudos Pós-Graduação em História e do Dep. De História da PUC-SP. São Paulo, 1981.

OLIVEIRA, Olívia. Quarto de arquiteto: Lina Bo Bardi e a história. Revista Óculum, Campinas, n.5/6, p.83-88, mai/1995.

. Lina Bo Bardi: sutis substâncias da arquitetura. São Paulo: Romano Guerra Editora/ Gustavo Gilli, 2006.

PACI, Enzo. II cuore della città. In: Casabella Continuità, n.202, ago-set, 1954.

PANE, Roberto. Antico e nuovo. Casabella, n. 297, 1964.

PAOLI, Maria Célia. Memória, história e cidadania: o direito ao passado. In: CUNHA, Maria Clementina Pereira (org.). O direito à memória. São Paulo: Brasil/Printed, 1991.

PEREIRA, Juliano Aparecido. A ação cultural de Lina Bo Bardi na Bahia e no Nordeste (1958-1964). Dissertação de Mestrado desenvolvida na Escola de Engenharia de São Carlos (USP-São Carlos). São Carlos, 2001.

PEREIRA, Margareth da Silva. Quadrados brancos: Le Corbusier e Lucio Costa. NOBRE, Ana Luiza; KAMITA, João Masao; LEONIDIO, Otavio; CONDURU, Roberto (orgs.) Um modo de ser moderno: Lucio Costa, São Paulo: Cosac \& Naif, pp. 227-28, 2004.

. Uma caixa de madeira e poesia. Arquitetura e Urbanismo, n.38, out-nov, 1991, p.88.

PESSOA, José (org.). Lucio Costa: documentos de trabalho. Rio de Janeiro: IPHAN, 1999.

PINHO, Osmundo S. de Araújo. Descentrando o Pelô: narrativas, territórios e desigualdades raciais no Centro Histórico de Salvador. Dissertação de mestrado em antropologia UNICAMP. Campinas, 1997.

RIEGL, Aloïs. Le culte moderne des monuments. Son essences et sa gênese. (Trad. Daniel Wieczorek). Paris: Seul, 1984.

REIS FILHO, Nestor. Quadro da arquitetura no Brasil. São Paulo: Perspectiva, 1983.

ROGERS, E. N; SERT,J.L.; TYRWHITT. J. El Corazón de la Ciudad: por una vida más humana de la comunidad. Congresos Internacionales de Arquitectura Moderna. Barcelona: Hoepli, S. L., 1955.

ROGERS, E. Nathan. Continuità. Casabella, n.199, pp. 1-3, dez. 1953- jan. 1954. Discontinuità o continuità? Casabella Continuittà, n.294-295, dez-jan, pp.1-2, 1964-65. . Experiencia de la arquitectura. Buenos Aires: Ediciones Nueva Vision, 1965, p.37. 
La tradizione dell'architettura moderna italiana. Casabella Continuittà, n.206, jul-ago, pp.1-2, 1955.

Le responsabilità verso la tradizione. Casabella Continuittà, n.202, ago-set, pp.1-3, 1954.

ROSSETI, Eduardo Pierrotti. Tensão moderno/popular em Lina Bo Bardi: nexos da arquitetura.

Disponível em http://www.vitruvius.com.br/arquitextos/arq000/esp165.asp. Acesso em 12/05/2006.

ROSSI, Aldo. La Arquitectura de la ciudad. Barcelona: Gustavo Gilli, 1999.

RUBINO, Silvana Barbosa. O mapa do Brasil passado. In: Revista do Patrimônio Histórico e artístico nacional, n.24, pp.97-105, 1996.

. Rotas da Modernidade: trajetória, campo e história na atuação de Lina Bo Bardi, 1947-1968. Tese de Doutorado (Departamento de Antropologia na FFLCH - Unicamp). Campinas, 2002.

RUSKIN, John. Las siete lámparas de la arquitectura. Buenos Aires: Librería El Ateneo Editorial, 1956.

SANT'ANNA, Marcia. A cidade-atração: patrimônio e valorização de áreas centrais no Brasil dos anos 90. In: Cadernos PPG-AU/FAUUFBA (Territórios urbanos e políticas culturais). Número Especial. Salvador, 2004.

.Da cidade-monumento à cidade-documento. A trajetória da norma de preservação de áreas urbanas (1937-1990). Dissertação de Mestrado apresentada na Faculdade de Arquitetura e Urbanismo da Universidade Federal de salvador (UFBA. Salvador, 1995.

SANTOS, Cecília Rodrigues. Assim, nas bordas e por dentro, os ratos foram roendo toda nossa cidade da Bahia. Revista Projeto, n.142, jan-fev,1992, p.56

SANTOS, Mariza Veloso Motta. Nasce a academia SPHAN. In: Revista do Patrimônio Histórico e artístico nacional, n.24, p.77-95, 1996.

SCHULZ, Christian Norberg. Genius Loci. Paesaggio. Ambiente. Architettura. Milão: Electa, 1992.

SILVA, Geraldo Gomes. Intervenções em sítios históricos. Revista AU, ago, pp.80-84, 1996.

SILVA, Maria Angélica da. As casas da memória. Arquitetura e Urbanismo, n.38, out-nov, p.78-85, 1991. . As formas e as palavras na obra de Lucio Costa (Dissertação de Mestrado na Faculdade de Arquitetura e Urbanismo da PUC-RJ) Rio de Janeiro, 1991.

SIMÕES, José Geraldo. Anhangabaú: história e urbanismo. São Paulo: Editora Senac, 2004.

SITTE, Camillo. A construção das cidades segundo seus princípios artísticos. São Paulo: Ed. Ática, 1992.

SOLÀ-MORALES, Ignasi. Inscripciones. Barcelona: G. Gilli, 2003.

TAFURI, Manfredo. Storia dell'architettura italiana (1944-1985). Torino: Giulio Einaudi Editore, 1982

VIOLLET-LE-DUC, Eugène Emmanuel. Restauração. São Paulo: Ateliê Editorial, 2000.

WILHEIM, Jorge. De espaço a lugar. Arquitetura e Urbanismo. São Paulo, n.42, jun-julh, 1992.

WIPLI, Mônica. Intervenções urbanas em Centros Históricos. Estudo de Caso: cidade de Salvador. Dissertação de Mestrado apresentada na Faculdade de Arquitetura e Urbanismo da Universidade de São Paulo (FAU-USP). São Paulo, 2001.

WISNIK, Guilherme. Lina Bo Bardi: a interpretação cultural do Brasil 'pós-Brasília' Folha de São Paulo (Caderno llustrada), 11 de janeiro de 2006.

ZEIN, Ruth Verde. Fábrica da Pompéia, para ver e aprender. Revista Projeto, São Paulo, n.147, jan-fev, 1992.

ZEVI, Bruno. Contro oghi teoria dell'ambientamento. L'Architettura Cronache e Storia, n.118, pp.212-13, 1965. . Lina Bo Bardi: um architetto in tragitto ansioso. Revista Caramelo. São Paulo, n.4, 1992. 
Visione prospettica e spazio-temporalità nella'architettura moderna.

L'Architettura Cronache e Storia, n.111, pp.322-323,1956.

ZUCCONI, Guido. La città contesa: dagli ingegneri sanitari agli urbanisti (1885-1942). Milão: Jaca Book, 1989.

\section{artigos publicados em jornais e revistas}

Segurança deve vir antes da estética. Folha de São Paulo, São Paulo, jan., 1981.

Anhangabaú: o concurso para organização do espaço urbano. A Construção em São Paulo (1725): 1981, p. 18;

Anhangabaú: reorganização do espaço é colocada em debate. A Construção em São Paulo (1731): 1981; pp. 22-23.

0 novo Anhangabaú: mais um passo para a revitalização do Centro. $A$ Construção em São Paulo (1741), 1981, pp.4-11.

Um projeto voltado para o futuro. A Construção em São Paulo (1745): 1981; pp. 12-6.

As cinco menções honrosas do concurso de reurbanização do vale do Anhangabaú. A Construção em São Paulo (1755): 1981; pp. 16-22.

Justificativa técnica para as três novas passarelas. Arquitetura e construção. São Paulo, n.170, novembro de 1980.

Vale do Anhangabaú: nova feição do centro. Arquitetura e Urbanismo. São Paulo, n.42, junho/julho de 1992, pp.32-39.

Centro Histórico de Salvador. Patrimônio (Boletim informativo IPAC / SEC). Salvador, ano III, n.8, outubro/dezembro de 1985, 8p.

Programa para recuperar Núcleos Históricos. Patrimônio (Boletim informativo IPAC I SEC). Salvador, ano III, n.9, janeiro/maio de 1986, 6p.

Exclusivo: os primeiros estudos sobre o Vale do Anhangabaú. Revista Projeto. São Paulo, n.28, abril/maio de 1981, pp.14-17.

A comunidade quer e pode se manifestar, afirma Bergstron. Revista Projeto. São Paulo, n.29 maio de 1981, pp.44-47.

Anhangabaú: uma conquista dos arquitetos e da população. Revista Projeto (suplemento especial). São Paulo, n.31, julho de 1981, p.33-54.

EMURB vence contradições e resgata o centro da cidade. Revista Projeto. São Paulo, n.138, fevereiro de 1991, pp.51-57.

Novas luzes na Bahia. Jornal da Bahia. Salvador, 11 de novembro de 1988. Revista (Suplemento Cultural), p.5-7.

Operação Urbana Anhangabaú. Revista Projeto. São Paulo, n.138, fevereiro de 1991, pp.58-69.

\section{publicações institucionais}

IPAC, Folheto de divulgação do projeto piloto, 1985. Encontrado no arquivo do Instituto Lina Bo e P. M. Bardi.

Jornal do IAB. São Paulo, ano 1, n.9, julho de 1981.

EMURB/ PMSPI IAB. Concurso Público Vale do Anhangabaú. São Paulo, fev, 1981.

Programa Nacional para recuperar Núcleos Históricos. Patrimônio (Boletim Informativo do IPAC/SEC, Salvador, n.9, janeiro/maio, 1986, p.3. 